\title{
Three Essays in Banking and Finance
}

by

Yinlin Zhang

A thesis submitted to the Faculty of Graduate and Postdoctoral Affairs in partial fulfillment of the requirements for the degree of

Doctor of Philosophy

in

Management

Carleton University

Ottawa, Ontario

(C) 2019

Yinlin Zhang 


\section{Abstract}

This thesis is a collection of three essays with a common theme on the riskiness of banks. The first essay (Chapter 2) examines how banks' discretionary accounting practices affect banks' stock trading liquidity and stock price crash risk. Bank managers can use discretionary loan loss provisioning practices to obscure information on banks' performance and riskiness, thus elevating information uncertainty among investors. We find empirical evidence confirming that banks with greater opacity, as measured by the discretionary loan loss provisioning $(D L L P)$ practice, are associated with greater stock trading illiquidity and higher stock price crash risk.

The second essay (Chapter 3) examines depositors' tendency to apply financial discipline to banks that adopt discretionary accounting practices. We find that uninsured deposit growth is negatively associated with banks' DLLP. The findings suggest that depositors punish banks' discretionary accounting practices. We also find that within the non-too-big-to-fail (non-TBTF) banks, depositors react sensitively to $D L L P$ during both the 2008 financial crisis and non-crisis periods. However, for those so-called too-big-tofail (TBTF) banks, depositors react sensitively to $D L L P$ practices only during the non-crisis period, but not during the crisis period. In addition, banks subject to U.S. government bailout actions during the 2008-2009 crisis period received less depositor discipline than other banks.

The third essay (Chapter 4) examines whether tail risk for respective real (i.e., nonfinancial) sub-sectors appears to be affected by risk emanating from the financial sector. We use the Conditional Value-at-Risk ("CoVaR") approach to examine which real subsectors are more vulnerable to risk emanating from the financial sector by measuring the 
change in $\mathrm{CoVaR}$ in each real sub-sector when the financial sector moves from a normal state to a stressed state. We find that the spillover effect from the financial sector to real sub-sectors reached the highest levels in our sample period before the 2008 financial crisis and dramatically decreased once the financial crisis had started. By comparing the backtesting results of our $\mathrm{VaR}$ and $\mathrm{CoVaR}$ estimations, we also find that the CoVaR measure can be a more reliable indicator of risk during very volatile market periods than the traditional VaR measure. 


\section{Acknowledgements}

I would like to express my sincere gratitude to my supervisor, Prof. Michael McIntyre. This work would not have been possible without his continued support and professional guidance throughout the thesis process. I am truly thankful and in debt for his mentorship through my Ph.D. years.

I am also grateful for the assistance and valuable suggestions from my dissertation committee members, Prof. Sana Mohsni and Prof. Mohamed Al Guindy. Thanks to Prof. Lorne Switzer and Prof. Michel Demers for their time and effort to participate on the committee.

I would thank the faculties and my Ph.D. colleagues at Sprott School of Business. Thanks to Prof. Isaac Otchere and Prof. Ouafa Sakka for their insightful comments on my comprehensive exam paper. Thanks to Dr. Erin Oldford for her help on my research and teaching. Thanks to Greg Schmidt for the help in database needs.

Finally, I would like to thank my family for their unconditional love and support. Sincere thanks to my husband and my parents for always being there for me. I dedicate this thesis to them.

I acknowledge the financial support from Ontario Trillium scholarships, George Mulligan Memorial Scholarship in Investment Research, and Kyle and Monica Mital Scholarship in Finance and Accounting. 


\section{Table of Contents}

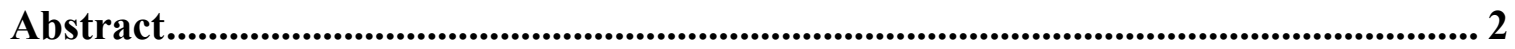

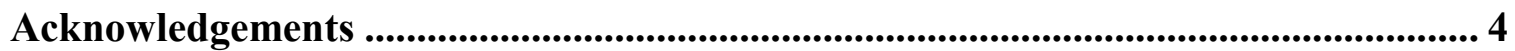

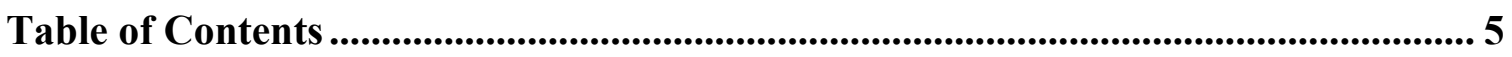

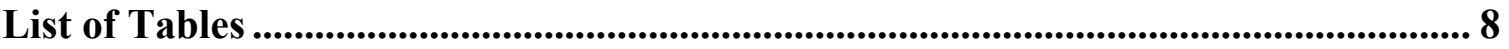

List of Figures........................................................................................................................ 10

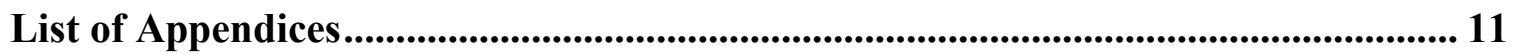

Chapter 1: Introduction ............................................................................................................ 12

Chapter 2: Discretionary Loan Loss Provisioning, Stock Trading Liquidity, and

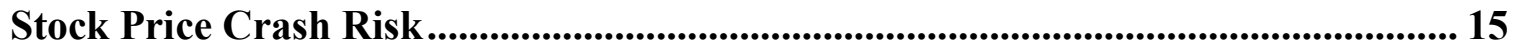

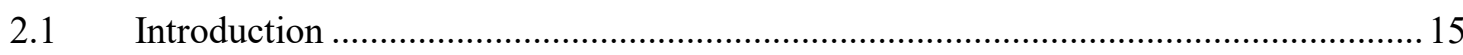

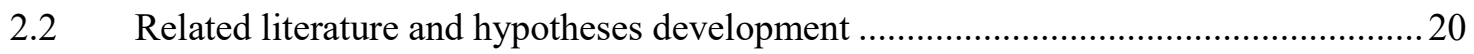

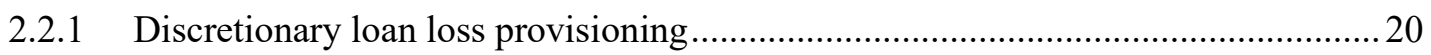

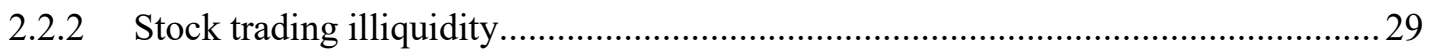

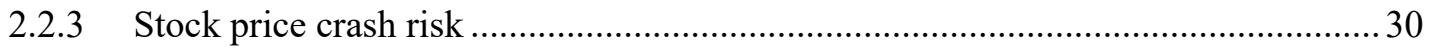

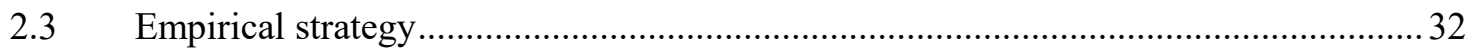

2.3.1 Discretionary loan loss provisions and stock trading illiquidity .............................32

2.3.2 Discretionary loan loss provisions and stock price crash risk ................................. 37

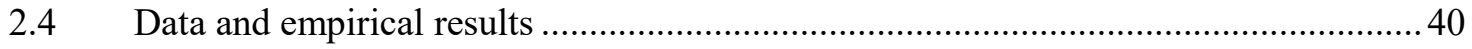

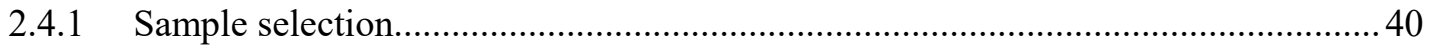

2.4.2 Discretionary loan loss provisioning: the estimation results................................ 41

2.4.3 Empirical results for the relation between DLLP (and ADLLP) and STI ............... 43

2.4.4 Empirical results for the relation between $D L L P$ ' and $S P C R \ldots \ldots \ldots \ldots \ldots \ldots \ldots \ldots \ldots \ldots . . . . . .54$

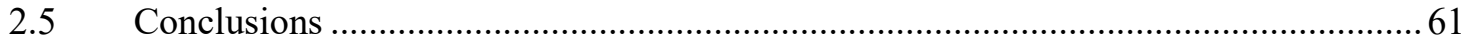

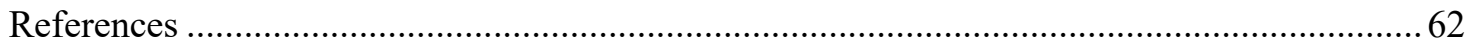




\section{Chapter 3: Depositors' Discipline, Banks' Accounting Discretion, and Depositors'}

Expectations of Implicit Government Guarantees ........................................................... 66

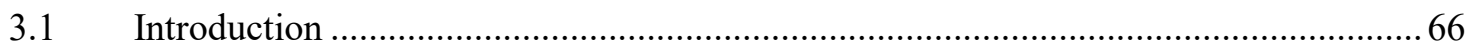

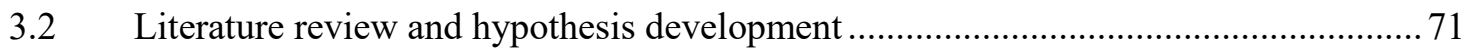

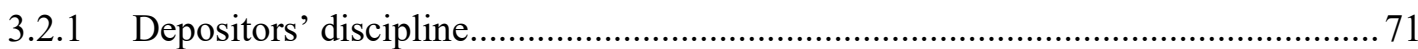

3.2.2 Do investors react to poor financial reporting quality? ......................................... 74

3.2.3 The relationship between too-big-to-fail expectations and market discipline.......... 78

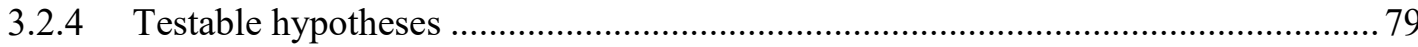

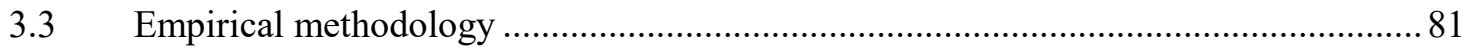

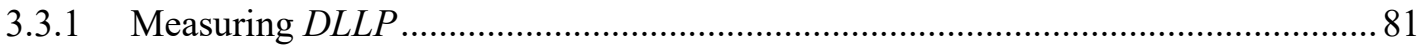

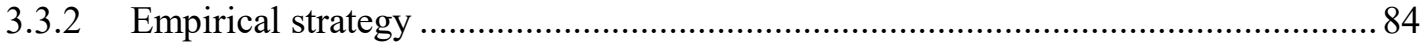

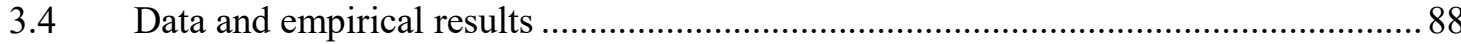

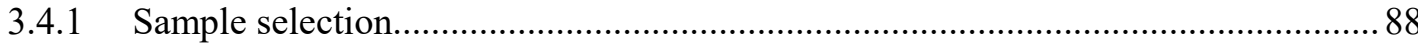

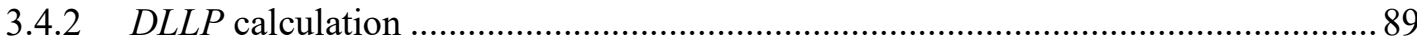

3.4.3 Summary statistics and univariate analysis........................................................... 91

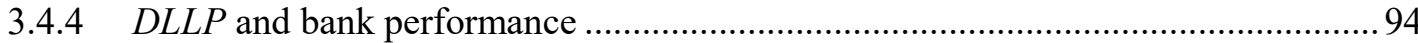

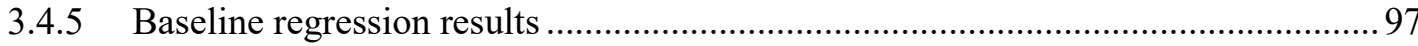

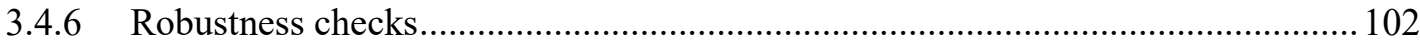

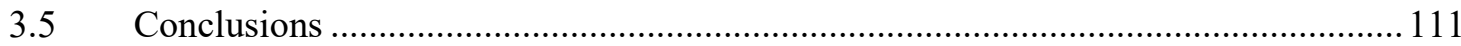

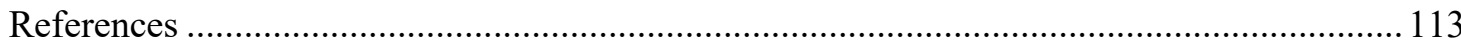

\section{Chapter 4: Estimating Financial Sector Risk Spillover: A Conditional Value-at-}

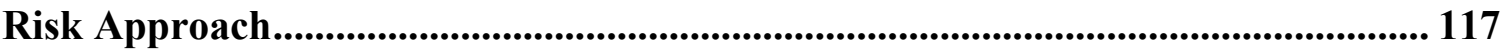

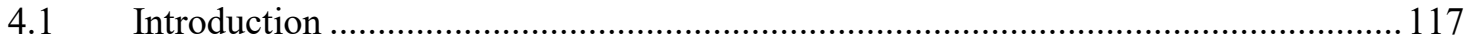

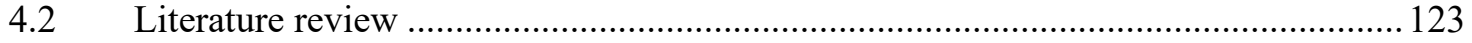

4.2.1 Stress in the financial sector and consequences for real sub-sectors..................... 123

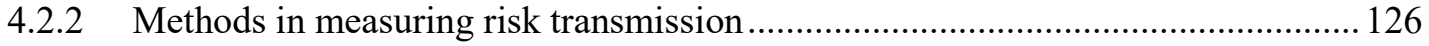




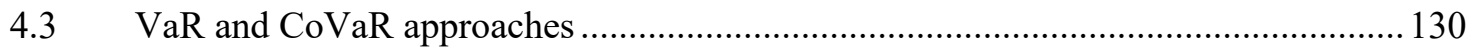

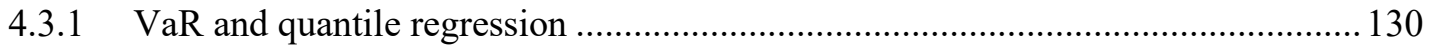

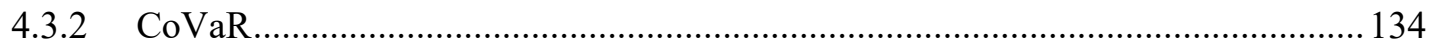

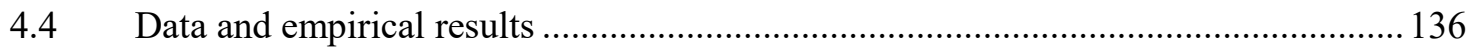

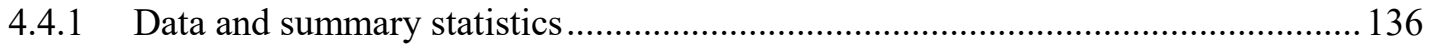

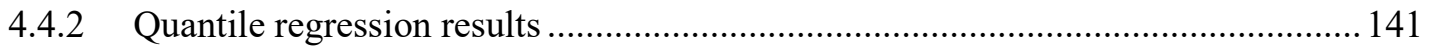

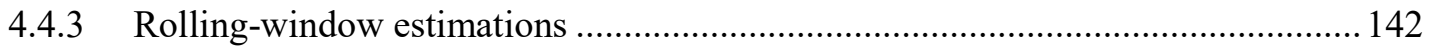

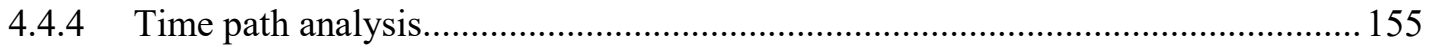

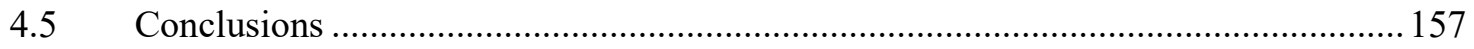

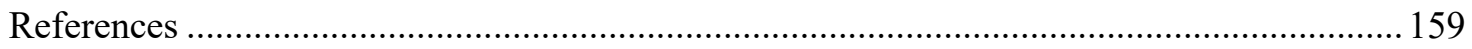

Chapter 5: Summary and Conclusions ............................................................... 162

Appendices................................................................................................................................ 164

Appendix A for Chapter 2: An alternate provisioning presentation ...................................... 164

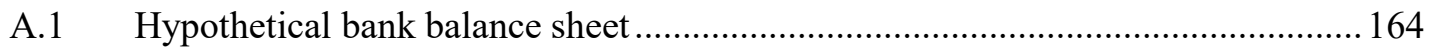

A.2 Hypothetical bank income statement …............................................................ 165

Appendix B for Chapter 2: Variable definitions and data source ........................................ 166

Appendix C for Chapter 3: Variable definitions and data source ........................................... 169

Appendix D for Chapter 4: Definitions of sectors ......................................................... 171

Appendix E for Chapter 4: Forecasts of VaR, CoVaR and $\Delta \mathrm{CoVaR}$ for 16 real sub-sectors 172 Appendix F for Chapter 4: Time-varying coefficients and error bands for 16 real sub-sectors

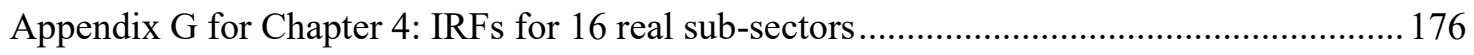




\section{List of Tables}

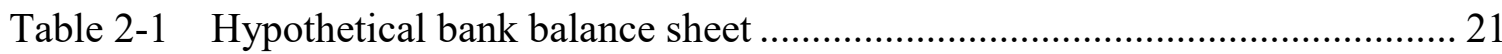

Table 2-2 Hypothetical bank income statement........................................................ 22

Table 2-3 An example of accounting entries for charge-offs and loan loss provisions. 23

Table 2-4 Regression results of loan loss provision models........................................... 41

Table 2-5 Correlation matrix of the four $D L L P$ measures ............................................ 42

Table 2-6 Correlation matrix of the four $A D L L P$ measures .......................................... 43

Table 2-7 Descriptive statistics based on bank-quarter observations between 2000Q1 to

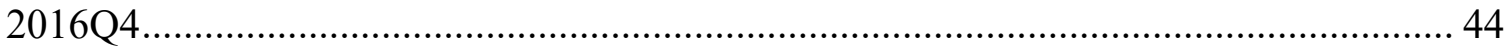

Table 2-8 Correlation matrix for testing the relation between $D L L P$ (and ADLLP) and

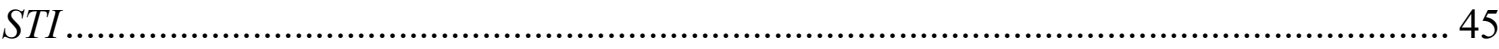

Table 2-9 The regression results for the relation between DLLP and Amihud ............. 46

Table 2-10 The regression results for the relation between DLLP and BidAsk ............ 47

Table 2-11 The regression results for the relation between $D L L P$ and ZERO ............. 48

Table 2-12 ADLLP and STI: additional analysis........................................................ 53

Table 2-13 Descriptive statistics based on bank-year observations between 2000 to

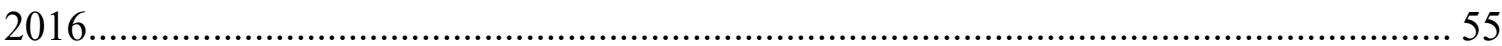

Table 2-14 Correlation matrix for testing the relation between DLLP (and ADLLP) and SPCR

Table 2-15 The regression results for the relation between $D L L P$ ' and $S P C R$............ 56

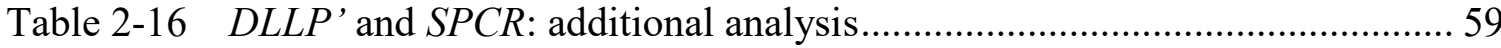

Table 3-1 Regression results of loan loss provision models .......................................... 90

Table 3-2 DLLPs' correlation coefficients ............................................................... 91 
Table 3-3 Summary statistics on bank and macro variables ................................... 92

Table 3-4 Summary statistics on non-TBTF banks and TBTF banks ........................ 93

Table 3-5 The baseline regression results .......................................................... 98

Table 3-6 Using the ADLLP1 measure for the baseline regression ......................... 101

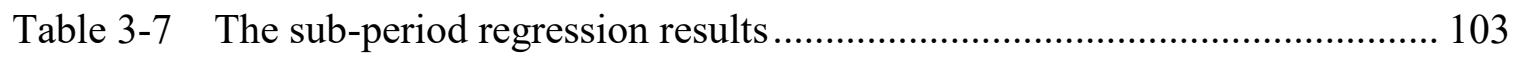

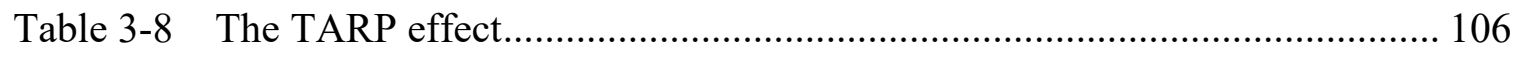

Table 3-9 Using alternative bank size cut-offs ................................................ 108

Table 3-10 Using alternative DLLP measures ................................................. 110

Table 4-1 Summary statistics for sector returns …........................................... 139

Table 4-2 Summary statistics for state variables …........................................... 140

Table 4-3 Coefficients of the CoVaR model ....................................................... 142

Table 4-4 Summary statistics of one-day-ahead VaR99\% estimates.......................... 143

Table 4-5 Summary statistics of one-day-ahead CoVaR $99 \%$ estimates ...................... 144

Table 4-6 Summary statistics of one-day-ahead $\Delta \mathrm{CoVaR}_{99 \%}$ estimates.................... 144

Table 4-7 Rankings of real sub-sectors............................................................. 146

Table 4-8 Back-testing - Bernoulli Coverage Test and Independence of Violations Test 153 


\section{List of Figures}

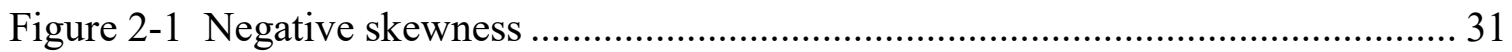

Figure 3-1 Boxplots of performance indicators between High_DLLP and Low_DLLP

groups

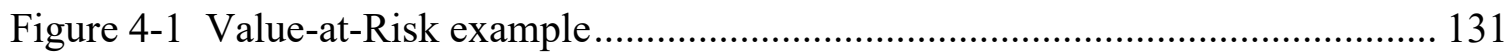

Figure 4-2 Value-at-Risk example: equivalent illustration......................................... 132

Figure 4-3 The relationship between $\mathrm{CoVaR}_{99 \%}$ and $\mathrm{VaR}_{99 \%}$, and between $\Delta \mathrm{CoVaR}_{99} \%$

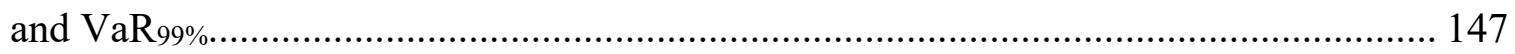

Figure 4-4 Mining sector realized losses and daily estimates of $\mathrm{VaR}_{99 \%}$, CoVaR ${ }_{99 \%}$

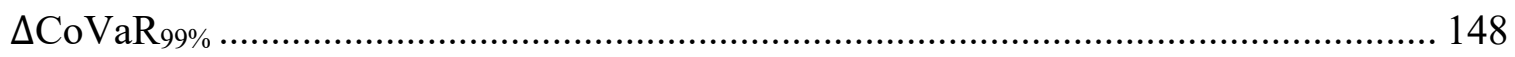

Figure 4-5 Time-varying coefficients and error bands for the Mining sector ............... 150 


\section{List of Appendices}

Appendix A for Chapter 2: An alternate provisioning presentation ......................... 164

A.1 Hypothetical bank balance sheet........................................................ 164

A.2 Hypothetical bank income statement ................................................ 165

Appendix B for Chapter 2: Variable definitions and data source ............................. 166

Appendix C for Chapter 3: Variable definitions and data source ............................ 169

Appendix D for Chapter 4: Definitions of sectors .......................................... 171

Appendix E for Chapter 4: Forecasts of $\mathrm{VaR}, \mathrm{CoVaR}$ and $\Delta \mathrm{CoVaR}$ for 16 real sub-

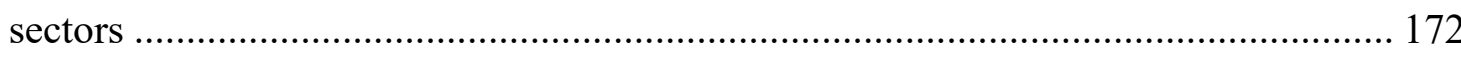

Appendix F for Chapter 4: Time-varying coefficients and error bands for 16 real sub-

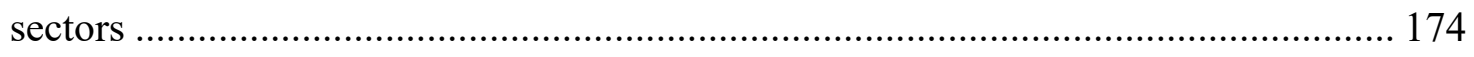

Appendix G for Chapter 4: IRFs for 16 real sub-sectors .................................... 176 


\section{Chapter 1: Introduction}

This thesis is a collection of three essays with a common theme on the riskiness of banks. The first two essays examine riskiness arising within the financial sector. The focus is on how banks' discretionary accounting practices affect banks' risk profiles and how banks' investors respond to banks when they exercise accounting discretion in an opportunistic way. The third essay examines how tail risks from the financial sector are related to tail risks in other real sub-sectors.

Loan loss provisioning is a key bank accounting practice that directly influences banks' earnings and reflects the risk attributes of banks' loan portfolios. Bank managers can record a loan loss provision that deviates from one that is notionally correct in order to obscure information on banks' performance and riskiness, thus elevating information uncertainty among investors. The difference between an observed loan loss provision and a notionally correct loan loss provision is referred to as an unexpected or discretionary loan loss provisions $(D L L P)$. Banks associated with $D L L P$, and other opportunistic accounting practices, are said to be financially opaque. Theory suggests that opacity in financial reporting can lead to reduced levels of stock trading liquidity and elevated levels of stock price crash risk. In our first study, presented in Chapter 2, we examine whether DLLP is correlated with firm opacity features as reflected in the stock market. Using data from U.S. public banks, we find that, banks associated with a higher level of accumulated $D L L P$, are more likely to experience reduced stock trading liquidity and elevated levels of stock price crash risk. These findings confirm the notion that $D L L P$ reduce firms' financial information quality, leading to greater firm opacity, which in turn affects banks' stock trading liquidity and extreme stock price behavior. 
In our second study, presented in Chapter 3, we examine the relationship between depositors' tendency to exercise financial discipline over banks and banks' tendency to adopt $D L L P$ practices. We posit that if depositors perceive that opportunistic accounting practices increase banks' credit risk, depositors will punish banks by withdrawing deposits or requiring higher interest rates. Using data from U.S. commercial banks, we find that the uninsured deposit growth is negatively associated with banks' $D L L P$. The findings confirm the hypothesis that depositors are aware of banks' discretionary accounting practices and punish these banks by withdrawing deposits. We also find that for so-called too-big-to-fail (TBTF) banks, depositors react sensitively to $D L L P$ practices only during the non-crisis period, but not during the crisis period. In addition, banks subject to U.S. government bailout actions during the 2008-2009 crisis period received less depositor discipline than other banks. These results support the notion that market discipline is weaker for the big banks that present as being under the protection of explicit or implicit government guarantees.

Our third study, presented in Chapter 4, examines connections between the financial sector and real (i.e., non-financial) sub-sectors with a focus on whether real subsectors' respective tail risks are related to risk emanating from the financial sector. Using the Conditional Value-at-Risk (CoVaR) approach developed by Adrian and Brunnermeier (2016), we quantify the magnitude of risk spillovers from the financial sector to respective real sub-sectors. We define CoVaR as the Value-at-Risk of a real sub-sector conditional on the financial sector being in distress. We examine which sectors are more vulnerable to risk originating from the financial sector by measuring the change in CoVaR in real subsectors, respectively, when the financial sector moves from a normal state to a stressed 
state. We find that, first, the tail risks in stock price of the real sub-sectors are closely associated with the financial sector's stock price. The Mining, Steel, Oil, and Cars sectors are the four sectors most vulnerable to risk originating from the financial sector. We also find that the spillover effect from the financial sector to real sub-sectors reached the highest levels in our sample period before the 2008 financial crisis and present as dramatically reduced upon the commencement of the crisis. Second, by comparing the back-testing results of our VaR and CoVaR estimations, we find that the CoVaR measure can be a more reliable indicator of risk during very volatile market periods than the traditional VaR measure. Finally, by analyzing the time path of each real sub-sectors reaction to shocks originating from the financial sector, we see that the real sub-sectors' stock returns respond to shocks originating from the financial sector's stock returns immediately (in one day) and that the effects attenuate over the ensuing two weeks. In general, the results from this study suggest that real sub-sectors are closely related to the financial sector in terms of the tail risk of equity prices. The CoVaR measure we propose in this study can be a more conservative tail risk indicator than the traditional VaR measure.

The remainder of this thesis is organized as follows. Chapter 2 to Chapter 4 are comprised of the three essays. Within each essay, we present the introduction, literature review, empirical strategy, sampling approach and the empirical results. Chapter 5 provides the summary and conclusions. 


\section{Chapter 2: Discretionary Loan Loss Provisioning, Stock Trading \\ Liquidity, and Stock Price Crash Risk}

\subsection{Introduction}

The 2007-2009 financial crisis has prompted an assessment of banks' accounting practices. Some studies find that banks were increasingly using opportunistic accounting practices during the financial crisis (Vyas, 2011; Huizinga and Laeven, 2012). Opportunistic accounting practices can be motivated by bank managers' compensation issues, private benefits, and capital ratio concerns (Beatty and Liao, 2014). Among the available candidates for opportunistic accounting practices, loan loss provisioning is a key one that directly influences banks' earnings and reflects the risk attributes of banks' loan portfolios. Banks can act opportunistically by adjusting a notionally correct loan loss provision by incrementing or decrementing the notionally correct amount by what has come to be called a discretionary loan loss provision ${ }^{1}$ ("DLLP") $)^{2}$. Banks may use $D L L P$ to smooth income, signal portfolio quality strength, manage their capital ratios, and gain regulatory forbearance (Bushman, 2016).

One potential consequence of booking a DLLP is that it may increase banks' financial reporting opacity and increase investors' uncertainty, which in turn can affect stock price by inducing stock trading illiquidity (“STP”). Ongoing use of DLLP can also increase stock price crash risk ("SPCR") if substantial information obscured by doing so

\footnotetext{
${ }^{1}$ Some authors use the term 'discretionary loan loss provision' to denote the provision one observes and use the term 'unexpected loan loss provision' to denote the difference between the observed provision and the notionally correct provision. The terminology described in the body of this report follows that used by Beatty and Liao (2014).

${ }^{2}$ Abbreviations are defined the first time they appear in a chapter whether or not they have been defined in a preceding chapter.
} 
comes to be known to financial markets all at once. This study investigates the empirical links between banks' DLLP practices and these possible observable consequences.

First, we consider STI. Investors in more opaque firms are exposed to higher risk of informed trading. When a firm is opaque, less informed investors may worry that they are at an information disadvantage in a trade and that their trading counterparties may have better information. In this circumstance, those less informed investors can become more reluctant to trade stocks for more opaque firms. Consequently, opaque firms are associated with greater STI (Kyle, 1985). Empirical evidence supports the hypothesis that better disclosure is associated with lower information asymmetry and higher liquidity (e.g., Welker, 1995; Amihud, 2002; Healy, Hutton, and Palepu, 1999; Leuz and Verrecchia, 2000; and Lang, Lins, and Maffett, 2012). In banking sector, there is very little evidence on the relationship between banks' opacity and stock trading liquidity. We contribute to the literature by examining whether banks' opacity, which is measured by $D L L P$, is related to stock trading liquidity.

In this study, we measure $S T I$ in three ways: The Bid-ask spread (Welker, 1995); the 'price impact' illiquidity measure presented in Amihud (2002); and, the ratio of zero return days over total trading days (Lesmond, Ogden, and Trzcinka, 1999). We examine whether the apparent adoption of $D L L P$ is negatively associated with bank STI.

Second, we consider SPCR. We define $S P C R$ as extreme negative stock returns after netting out market-wide influences. When bad news arrives, firm managers have an incentive to conceal it or delay announcing it with the hope that future good news will offset the impact of the bad news, thus ameliorating stock price volatility. However, managers' ability to conceal bad news is limited. If the amount of accumulated bad news 
becomes large, and managers become unable to conceal it, its arrival on the market all at once can lead to an extreme negative return. Jin and Myers (2006) show that if a firm serially conceals bad news, the future release of accumulated bad news can cause a stock price crash. Therefore, more opaque firms are more likely to experience stock price crashes.

A number of studies find empirical evidence that opaque firms, as measured by firms' discretionary earnings accruals, are associated with higher probability of stock price crashes (e.g., Hutton, Marcus, and Tehranian, 2009; Hong, Kim, and Welker, 2017; Hung and Qiao, 2017). In terms of evidence from the banking sector, Cohen, Cornett, Marcus, and Tehranian (2014) find that banks' aggressive earnings management prior to 2007 is related to more severe worst-week returns during the crisis period. Bushman and Williams (2015) find delayed recognition of loan losses is associated with higher tail risk as measured by Value-at-Risk and Conditional Value-at-Risk. In this study, we estimate $S P C R$ using the negative skewness of bank-specific stock returns distributions and we test if this is positively related to banks' use of $D L L P$.

One way to find and quantify $D L L P$ is to estimate the non-discretionary component of loan loss provisions (LLP) and treat this as the 'normal' (or 'correct') provision. The difference between the recorded provision and the non-discretionary provision is taken as the $D L L P$. Since the non-discretionary provision is usually estimated using a regression model, $D L L P$ amounts to a regression residual.

One important thing in estimating discretionary loan loss provisions is to determine the predictors for the non-discretionary (or normal) loan loss provisions. The earnings management literature in non-bank sectors usually adopts some commonly used 
discretionary accruals models. Unlike this literature, there is little consensus in the banking literature on how to best model discretionary provisions. Different discretionary provisions models employ different "non-discretionary" predictors. Beatty and Liao (2014) compare the accrual models of loan loss provisions in the existing literature and identify a set of common factors used in the more commonly used loan loss provision models. They construct four LLP models using different combinations of these common factors and obtain the residuals from these LLP models as the proxies for $D L L P$. They test which $D L L P$ measure can more correctly capture the propensity of banks financial restatement and the receipt of SEC comment letters initiated due to loan loss provisioning related issues. Using this approach, they declare one of the models to be the best LLP model for the purpose of estimating $D L L P$.

Following Beatty and Liao (2014), a growing literature began using the DLLP generated by their preferred model as an indicator of bank opacity. For example, Jiang, Levine, and Lin (2016) document that bank competition reduces bank opacity, where opacity is measured using DLLP. Jin, Kanagaretnam, and Liu (2018) address the relationship between banks' funding structure and earnings' reporting quality, where the latter is measured by DLLP. Tran, Hassan, and Houston (2018) compare earnings quality between public and private banks, also using $D L L P$.

In this study, we extend Beatty and Liao (2014)'s work by examining how DLLP practices are associated with two widely documented firm opacity features: STI and SPCR. In particular, we ask this question: Does the choice of the LLP model matter for specifying the relationship between $D L L P$ and $S T I$ and the relationship between $D L L P$ and $S P C R$ ? To 
do so, we examine these relationships using each of Beatty and Liao's (2014) LLP models to see if we can identify useful performance differences.

In addition to examining banks' opacity using the immediately preceding period's $D L L P$, we consider whether $D L L P$ practices for multiple preceding periods, taken together, are informative. In other words, banks' opacity may be more appropriately measured by more than a single preceding period's $D L L P$ practice. Thus, we extend the approaches to examining the effects of $D L L P$ using accumulated $D L L P(A D L L P)$.

We find that our measure of opacity, the accumulated $D L L P(A D L L P)$, is a reliable predictor of STI. The findings confirm the notion that banks with greater opacity are associated with reduced stock liquidity. The results are robust when we perform additional robustness checks. The results are also not sensitive to the choice of using which LLP model to generate the $D L L P$ measure.

We also find that the accumulated $D L L P$ generated from the preferred LLP model from Beatty and Liao (2014), is a reliable predictor of SPCR. The results suggest that banks associated with greater opacity (using this $D L L P$ measure) are more likely to experience stock price crash risk. The association between $D L L P$ and $S P C R$ is stronger during the 2008-2009 financial crisis period.

Overall, the findings suggest, banks' discretionary provisioning practice, using our proxy for it, is related to the firms' opacity feature as manifested in their stock trading information. The major contribution of this study is that we compared which of the four DLLP measures generated from the four LLP models from Beatty and Liao (2014) can better capture banks' opacity. When the consequence of opacity is reduced stock trading liquidity, all the four DLLP measures can capture the opacity. When the consequence of 
opacity is increased stock trading liquidity, the DLLP measures generated from the first model from Beatty and Liao (2014) is doing a better job in capturing the bank opacity. A growing literature is using the $D L L P$ as a measure of banks' opacity. Our study provides future studies in this area a reference in choosing the appropriate LLP model to create the $D L L P$ measure.

In Section 2.2 we present a review of the relevant literature and develop hypotheses. In Section 2.3 we discuss the empirical estimation methods. In Section 2.4 we describe the sample and empirical results. We conclude in Section 2.5.

\subsection{Related literature and hypotheses development}

\subsubsection{Discretionary loan loss provisioning}

In this section, we discuss why loan loss provisioning is an important accounting matter that directly affects investors' and regulators' estimation of banks' earnings, regulatory risk capital ratio, and portfolio riskiness. Then we introduce approaches to estimating $D L L P$.

Banks set aside allowances for loan losses to deal with the possibility that some of the loans recorded as assets on their books may not be collectable. These allowances are typically recorded in an account denoted 'Allowance for loan losses', which is a contraasset account ${ }^{3}$ on banks' balance sheets (see the hypothetical bank balance sheet in Table 2-1). As such, the balance in the 'Allowance for loan losses' account reduces the book value of loans to the amount expected to be collected. Each accounting period, banks decide

\footnotetext{
${ }^{3}$ The account denoted 'Allowance for loan losses' is sometimes called 'Allowance for credit losses'.
} 
how much of their respective loan portfolios is of doubtful collectability and they increase or decrease 'Allowance for loan losses' accordingly. The offsetting entry to a change in 'Allowance for loan losses' on the balance sheet is to an income statement account called 'Provision for loan losses' (Balla, Rose, and Romero, 2012) (see the hypothetical bank income statement in Table 2-2). Sample accounting entries are shown in Table 2-3.

Table 2-1 Hypothetical bank balance sheet ${ }^{4}$

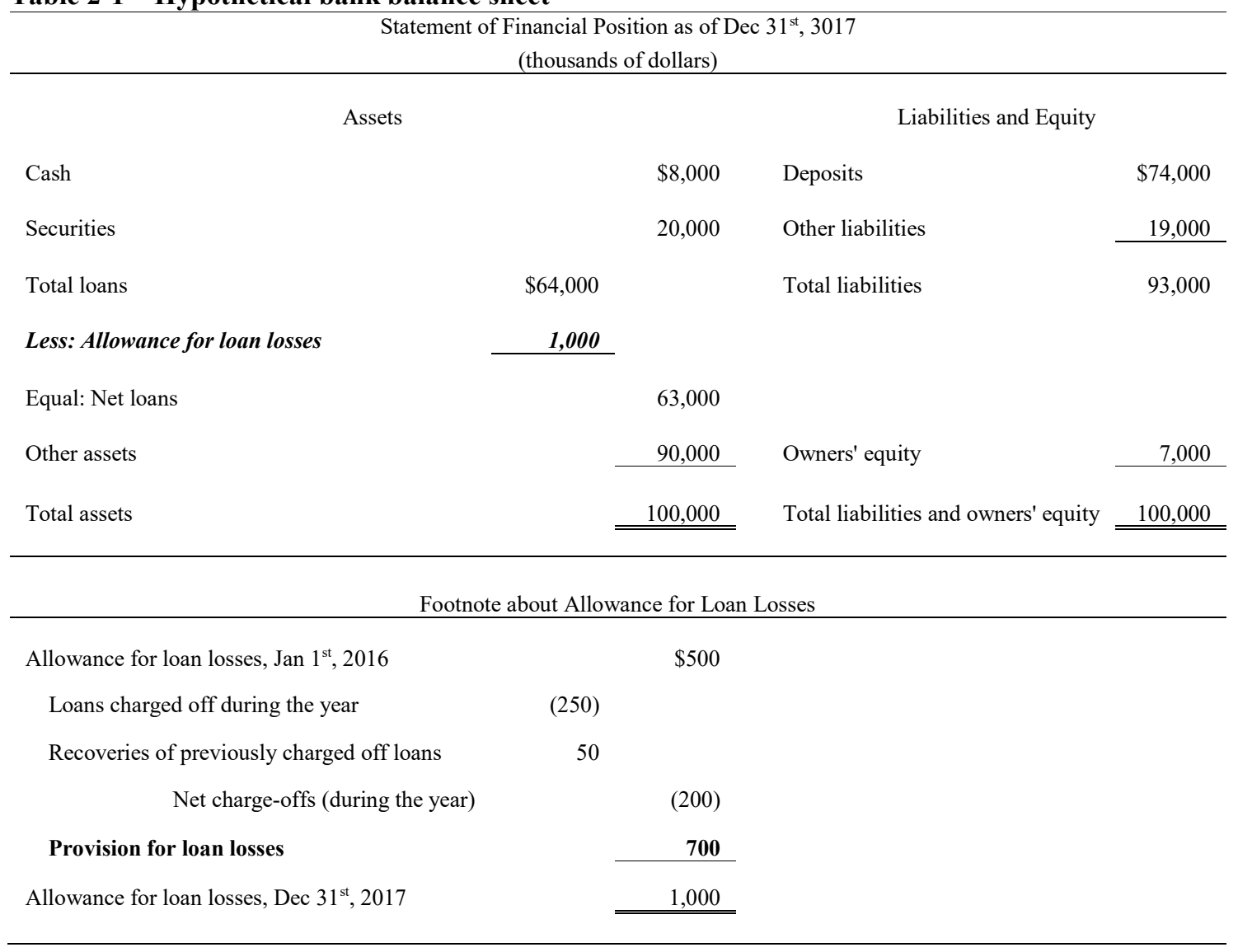

\footnotetext{
${ }^{4}$ Appendix A presents this example with recoveries of previously charged off loans booked directly to the
} income statement. 
Table 2-2 Hypothetical bank income statement

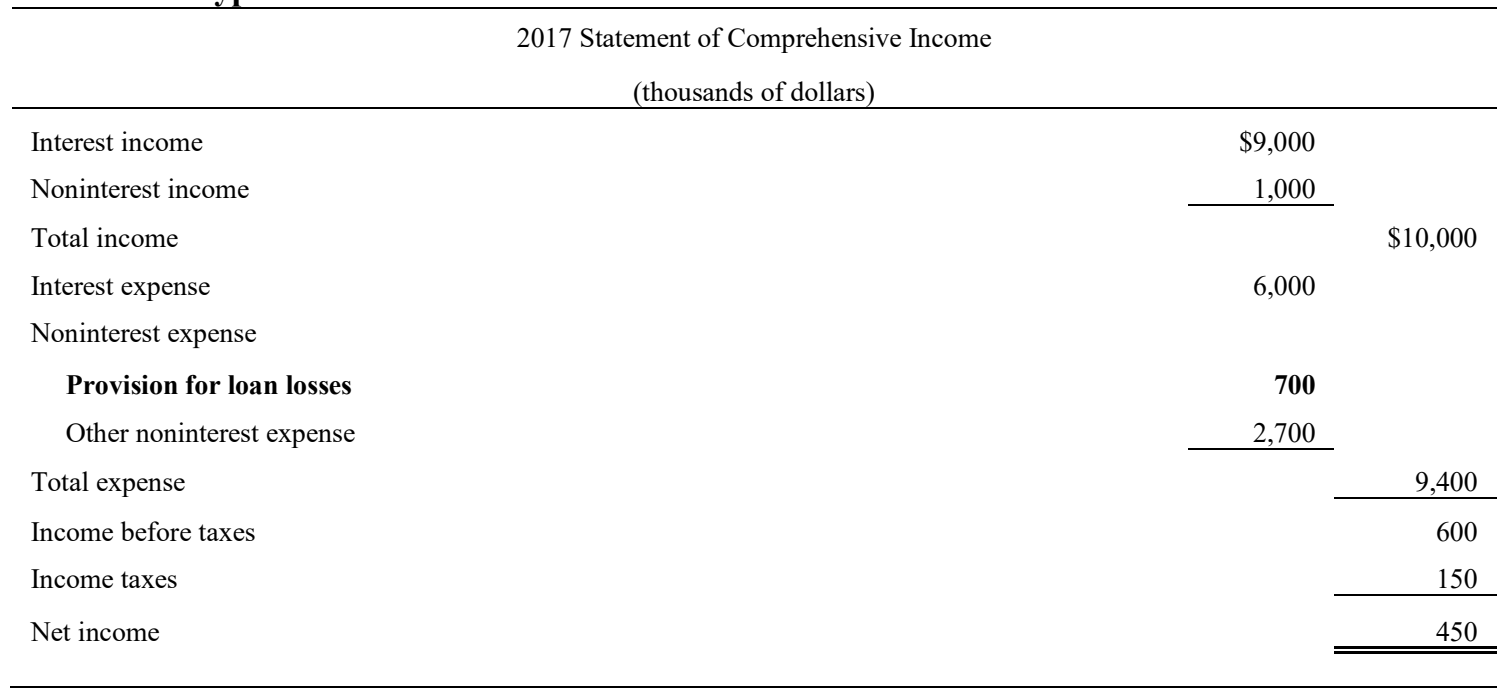

The balance in the 'Loan loss allowance' account is also affected by loan chargeoffs and recoveries of previously charged-off loans (see the footnote in Table 2-1). When it is virtually certain that a loan is uncollectable, a charge-off is recorded by reducing both the 'Allowance for loan losses' account and the loan account by the amount of the loan. If previously charged-off loans are eventually collected, the recovery is booked to the 'Allowance for loan losses', in effect as a reversal of the entry to the 'Allowance for loan losses' that was made at the time of the initial charge-off. Table 2-3 presents sample accounting entries. As can be seen from Table 2-3, the typical offsetting entry for recoveries is to $\operatorname{cash}^{5}$. The net of the entry to the 'Allowance for loan losses' in respect of charge-offs in the current year and the entry to record reversals due to recoveries in the current year of charge-offs made in preceding years is defined as 'Net loan charge-offs'.

\footnotetext{
${ }^{5}$ An exception would be the case in which an asset other than cash was recovered.
} 
Table 2-3 An example of accounting entries for charge-offs and loan loss provisions

\begin{tabular}{|c|c|c|c|c|}
\hline & Account Name & Debit & Credit & Explanations \\
\hline \multirow[t]{2}{*}{1} & Allowance for loan losses & & $\$ 700$ & $\begin{array}{l}\text { The allowance account is a balance sheet } \\
\text { contra account. Recording an allowance is } \\
\text { a credit to the allowance account } \\
\text { corresponding to a debit to an income } \\
\text { statement expense account. }\end{array}$ \\
\hline & Provision for loan losses & $\$ 700$ & & \\
\hline \multirow[t]{2}{*}{2} & Loans & & \multirow[t]{2}{*}{$\$ 250$} & \multirow{2}{*}{$\begin{array}{l}\text { An uncollectable loan is written off against } \\
\text { the allowance account. }\end{array}$} \\
\hline & Allowance for loan losses & $\$ 250$ & & \\
\hline \multirow[t]{2}{*}{3} & Cash & & \multirow[t]{2}{*}{$\$ 50$} & \multirow{2}{*}{$\begin{array}{l}\text { Collection of } \$ 50 \text { relating to previously } \\
\text { charged off loans. }\end{array}$} \\
\hline & Allowance for loan losses & $\$ 50$ & & \\
\hline
\end{tabular}

It can be observed from Table 2-1 to Table 2-3 that an increase in the 'Loan loss allowances' account on the balance sheet will increase the 'Loan loss provision expense' on the income statement, and this in turn will decrease the bank's reported net income. Consequently, setting the level of allowances for loans of doubtful collectability and correspondingly the level of loan loss provisions on the income statement directly affects several important bank performance and risk indicators, including earnings, leverage ratio, and risk-based capital ratios (Beatty and Liao, 2014).

Loan charge-offs should not affect banks' income statements because by the time inability to collect is virtually certain, banks' processes for setting allowances should ensure that such loans are fully allowanced. In other words, for every dollar of an almost assuredly uncollectable loan, there is an equal and offsetting dollar set up for it in an allowance account. If, however, a bank decides to write off a loan to the allowance account (i.e., effect a loan charge-off) that is not fully allowanced, executing a charge-off against the 'Loan loss allowance account' would serve to reduce the allowance to a level that is insufficient to cover collectability issues among the remaining loans in the portfolio. This would be corrected by increasing the current year's 'Provision for loan losses' by the amount required to bring the 'Allowance for loan losses' account up to what is needed to 
ensure that the net of the loans balance on the bank's books and the 'Allowance for loan losses' are in line with what appears to be collectable.

The level of loan loss allowances is supposed to reflect actual loan portfolio collectability issues. However, since drawing conclusions about collectability issues can depend on judgment, loan loss allowances and related provisions are at the bank managers' discretion. This enables bank managers to book provisions that are more or less than necessary with the purpose of smoothing income, meeting regulatory requirements, gaining more favorable tax treatment, or covering the true loan quality. For example, during an economic boom period, banks are more likely to set larger-than-necessary loan loss provisions and accumulate larger-than-necessary loan loss allowances to create a buffer that can absorb future credit impairments. During economic downturns, banks are more likely to set less-than-necessary loan loss provisions to mask deteriorating loan portfolio quality. Understatement of loan loss provisions sends a signal that overstates the quality of the loan portfolio. A positive consequence of engaging in DLLP practices is that this can reduce the volatility of bank profits and thus avoid negative effects on bank capital. A negative consequence is that these practices may reduce the information quality of financial reports and induce greater investor uncertainty about the bank's performance and fundamental riskiness. In addition, if the banks become unable to conceal deteriorating loan quality, the release of accumulated bad news may induce a stock price crash.

Relative to other accruals, loan loss provisions are large and explain a significant portion of the variability of total accruals. In addition, loan loss provisions are direct estimates of loan losses, which amounts to important information concerning the riskiness 
of a bank's loan portfolio (Beatty and Liao, 2014). ${ }^{6}$ It is for these reasons that it is important to understand banks' discretionary practices by focusing on banks' use of $D L L P$ and the consequences of doing so.

One way to measure $D L L P$ is to construct a loan loss provisions prediction model by regressing a set of predictors on loan loss provisions. The residuals of the fitted model (i.e., the unexplained/abnormal portion of the provisions) are estimates of the DLLP. An elevated level of unexplained provisions indicates an elevated level of $D L L P$.

To estimate the $D L L P$, one may start with a Loan Loss Provision (LLP) model: $L L P_{i, t}=\alpha_{0}+\alpha_{1}$ Predictors $+\varepsilon_{i, t}$. The fitted value $L \widehat{L P} P_{i, t}$ from the model captures the notionally non-discretionary (or normal) loan loss provisions, which result from a bank's normal operations and are free from management manipulation. The residuals $\varepsilon_{i, t}=$ $L L P_{i, t}-L \widehat{L P} P_{i, t}$ capture the discretionary (or abnormal) loan loss provisions denoted here as $D L L P .{ }^{7}$ This measure, in effect, quantifies bank managers' loan loss reporting manipulation to achieve goals such as meeting regulatory capital requirements or smoothing earnings.

\footnotetext{
${ }^{6}$ Other discretionary accounting choices include impairments, deferred taxes, gains and losses on securities, depreciation, change in loans held for sale, changes in other assets and liabilities (see Footnote 24 in Beatty and Liao (2014)).

${ }^{7}$ One may argue that because DLLP is obtained as the residuals of estimating an LLP model, the DLLP measure may contain measurement errors if the LLP model cannot precisely separate the discretionary accruals and non-discretionary accruals, resulting in incorrect inferences about the relationship between DLLP and other variables. McNichols (2002, p.67) expresses similar concerns: “ $\ldots$ to the extent a proxy for discretionary accruals contains measurement error that is correlated with the partitioning variables in a study's research design, inferences are affected". But McNichols (2002)'s argument mainly applies to the accounting discretion studies which focus on the aggregate accounting accruals. Modeling the aggregate accruals is complex and the measurement errors introduce large issues for these studies. However, for studies limited to modeling discretion in LLPs, the research advantage is that, by focusing on one specific accrual (i.e., DLLP) and one specific industry (i.e., banking sector), the complexity in modeling the specific accruals is much less than for modeling aggregate accruals. Researchers are able to develop intuition for the key factors that influence LLP, and therefore, better identify the discretionary component of LLP (also admitted by McNichols (2002)). Therefore, the measurement errors in DLLP should not be very large compared to the measurement errors in aggregate accruals.
} 
Estimating discretionary loan loss provisions requires us to determine predictors for the non-discretionary (or normal) loan loss provisions. The earnings management literature in non-bank sectors usually adopts some commonly used discretionary accruals models. However, in the banking literature, there is no consensus on how to best model discretionary provisions (Beatty and Liao, 2014). Different discretionary provisions models employ different "non-discretionary" predictors. For example, some studies treat the net charge-offs as the non-discretionary component and include the net charge-offs as a predictor in the LLP model. Other studies consider the net charge-offs as the discretionary component and exclude this variable from the LLP model ${ }^{8}$.

Beatty and Liao (2014) identify a set of common factors used in loan loss provision models and construct four LLP models using these common factors shown as equations (1) to (4) below. Each model generates its own DLLP measure. Beatty and Liao (2014) examine which of the four $D L L P$ measures is best correlated with the propensity for banks to restate their financial restatements and receive SEC comment letters caused by loan loss provisioning related issues. They assume that financial restatement and receipt of SEC comment letters represent the most direct evidence of provision manipulation and argue

${ }^{8}$ Prior studies hold different opinions on whether net loan charge-offs should be treated as a nondiscretionary control variable. On the one hand, some studies include net loan charge-offs as a nondiscretionary control variable in the LLP model (e.g., Beaver and Engel (1996), Kim and Kross (1998), Kanagaretnam, Krishnan, and Lobo (2010), Beck and Narayanamoorthy (2013)). This is because charge-offs do not directly affect income, managers may not have incentives to manipulate the charge-offs. On the other hand, some studies do not include this variable in LLP models (e.g., Wahlen (1994), Collins, Shackelford, and Wahlen (1995), Beatty, Chamberlain, and Magliolo (1995), Liu and Ryan (2006), Bushman and Williams (2012)). Liu and Ryan (2006) suggest that banks will exercise discretion over loan charge-offs to avoid too much fluctuation in the level of allowances for loan losses and to avoid scrutiny from bank regulators. Similarly, the prior studies also hold different in whether the loan loss allowance should be treated as a nondiscretionary control variable. 
that the $D L L P$ measure that is best correlated with these phenomena is the best $D L L P$ measure. Their test results show that model (1) is the best performing model.

$$
\begin{aligned}
& L L P_{i, t}=\alpha_{0}+\alpha_{1} \Delta N P A_{i, t+1}+\alpha_{2} \Delta N P A_{i, t}+\alpha_{3} \Delta N P A_{i, t-1}+\alpha_{4} \Delta N P A_{i, t-2}+\alpha_{5} \operatorname{SIZE}_{i, t-1}+ \\
& \alpha_{6} \Delta L O A N_{i, t}+\alpha_{7} \Delta G D P_{t}+\alpha_{8} \operatorname{CSRET}_{t}+\alpha_{9} \Delta U N E M P_{t}+\varepsilon_{i, t} \\
& L L P_{i, t}=\alpha_{0}+\alpha_{1} \Delta N P A_{i, t+1}+\alpha_{2} \Delta N P A_{i, t}+\alpha_{3} \Delta N P A_{i, t-1}+\alpha_{4} \Delta N P A_{i, t-2}+\alpha_{5} \operatorname{SIZE}_{i, t-1}+ \\
& \alpha_{6} \Delta L O A N_{i, t}+\alpha_{7} \Delta G D P_{t}+\alpha_{8} \operatorname{CSRET}_{t}+\alpha_{9} \Delta U N E M P_{t}+\alpha_{10} C O_{i, t}+\varepsilon_{i, t} \\
& L L P_{i, t}=\alpha_{0}+\alpha_{1} \Delta N P A_{i, t+1}+\alpha_{2} \Delta N P A_{i, t}+\alpha_{3} \Delta N P A_{i, t-1}+\alpha_{4} \Delta N P A_{i, t-2}+\alpha_{5} S \operatorname{SIZE}_{i, t-1}+ \\
& \alpha_{6} \Delta L O A N_{i, t}+\alpha_{7} \Delta G D P_{t}+\alpha_{8} \operatorname{CSRET}_{t}+\alpha_{9} \Delta U N E M P_{t}+\alpha_{10} A L W_{i, t-1}+\varepsilon_{i, t} \\
& L L P_{i, t}=\alpha_{0}+\alpha_{1} \Delta N P A_{i, t+1}+\alpha_{2} \Delta N P A_{i, t}+\alpha_{3} \Delta N P A_{i, t-1}+\alpha_{4} \Delta N P A_{i, t-2}+\alpha_{5} S \operatorname{SIZE}_{i, t-1}+ \\
& \alpha_{6} \Delta L O A N_{i, t}+\alpha_{7} \Delta G D P_{t}+\alpha_{8} \operatorname{CSRET}_{t}+\alpha_{9} \Delta U N E M P_{t}+\alpha_{10} A L W_{i, t-1}+\alpha_{11} C_{i, t}+\varepsilon_{i, t}
\end{aligned}
$$

Among the macro factors, $\triangle G D P$ is the change in GDP between quarter $t$ and quarter $t-1$. CSRET is the return on the Case-Shiller Real Estate Index between quarter $t$ and quarter $t-1 . \triangle U N E M P$ is the change in unemployment rates between quarter $t$ and quarter $t-1$. These three variables capture the macro-level factors that may be associated with loan loss provisions.

In addition to the factors included in model (1), models (2) to (4) also include $\mathrm{CO}_{i, t}$, defined as the net charge off divided by lagged total loans in quarter $t$ for bank $i$, and $A L W_{i, t-1}$, defined as the loan loss allowance divided by total loans in quarter $t-1$ for bank $i$ as predictors. The rationale for including $A L W$ is that if a bank carrying a sufficiently high 
level of loan loss allowance due to taking provisions in the past, it may recognize a low level of loan loss provision in the current period. The amount of $C O$ directly affects the level of allowance. Therefore, $C O$ may also affect the provisions.

The residuals of each LLP model represent the unexplained component of loan loss provisions. We use the absolute value of residuals $\left|\varepsilon_{i, t}\right|$ as indicators of $D L L P$ because both positive and negative residuals may reflect the use of $D L L P$ to augment the provision accounted for by the explanatory variables (Jiang, Levine, and Lin, 2017). So, the DLLP of bank $i$ at quarter $t$ is defined as $D L L P_{i, t}=\left|\varepsilon_{i, t}\right|$. We define $D L L P 1$ as the $D L L P$ measure generated from LLP model (1), DLLP2 as the DLLP measure generated from model (2), DLLP3 as the DLLP measure generated from model (3), and DLLP4 as the DLLP measure generated from model (4).

In addition to measuring banks' opacity by the one-period $D L L P$, we consider the case that banks manipulate their $D L L P$ for multiple periods before being detected. In other words, the stock trading behavior will be influenced by more than one period's DLLP practice. So, we further examine the provisioning practice by accumulated $D L L P(A D L L P)$. We define bank $i$ 's $A D L L P_{i, t}$ at quarter $t$ as the sum of $D L L P$ in quarter $t, t-1, t-2$, and $t-3$ :

$$
A D L L P_{i, t}=D L L P_{i, t}+D L L P_{i, t-1}+D L L P_{i, t-2}+D L L P_{i, t-3}
$$


We define $A D L L P 1_{i, t}$ as the accumulated $D L L P 1, A D L L P 2_{i, t}$ as the accumulated $D L L P 2, A D L L P 3_{i, t}$ as the accumulated $D L L P 3$, and $A D L L P 4_{i, t}$ as the accumulated DLLP4. ${ }^{9}$

In the empirical analysis discussed below, we measure banks' opacity by both $D L L P$ and $A D L L P$.

\subsubsection{Stock trading illiquidity}

Theory predicts that investors in more opaque firms are exposed to higher risk of informed trading. Opaque firms' investors are concerned that they may be at an informational disadvantage relative to trading counterparties. Therefore, if investors feel that a firm is less transparent, they become reluctant to trade, resulting in higher STI (Grossman and Stiglitz, 1980; Kyle, 1985; and Dahiya, Iannotta, and Navone, 2017). Increased financial transparency and accounting conservatism can reduce information asymmetries between firms and market participants or between informed and uninformed investors, which in turn increases the firms' stock trading liquidity (Amihud and Mendelson, 1986; Easley and O’Hara, 2004; Beyer, Cohen, Lys, and Walther, 2010).

Consistent with this argument, a few studies find that higher firm opacity is related to lower STI. For example, Welker (1995) finds a negative correlation between disclosure

\footnotetext{
${ }^{8}$ Following equation (5), the $4 A D L L P$ measures can be calculated as: $A D L L P 1_{i, t}=D L L P 1_{i, t}+D L L P 1_{i, t-1}+D L L P 1_{i, t-2}+D L L P 1_{i, t-3}$, $A D L L P 2_{i, t}=D L L P 2_{i, t}+D L L P 2_{i, t-1}+D L L P 2_{i, t-2}+D L L P 2_{i, t-3}$, $A D L L P 3_{i, t}=D L L P 3_{i, t}+D L L P 3_{i, t-1}+D L L P 3_{i, t-2}+D L L P 3_{i, t-3}$, $A D L L P 4_{i, t}=D L L P 4_{i, t}+D L L P 4_{i, t-1}+D L L P 4_{i, t-2}+D L L P 4_{i, t-3}$. We perform a sensitivity test and find that $A D L L P$ is a strong indicator for $S T I$ when using $4-8$ lagged $D L L P s$. In our robustness checks, we report the results when $A D L L P$ is calculated as the sum of 8 quarters' $D L L P: A D L L P_{i, t}=D L L P_{i, t}+D L L P_{i, t-1}+D L L P_{i, t-2}+D L L P_{i, t-3}+D L L P_{i, t-4}+D L L P_{i, t-5}+D L L P_{i, t-6}+$ $D L L P_{i, t-7}$.
} 
ratings and bid-ask spreads. Healy, Hutton, and Palepu (1999) find similar results. Leuz and Verrecchia (2000) find that the choice to adopt International Accounting Standards or the United States ("U.S.") Generally Accepted Accounting Principles is associated with an increase in liquidity for German DAX firms. Lang, Lins, and Maffett (2012) find that firms with less evidence of earnings management and adherence to accounting standards are associated with greater liquidity as measured by lower bid-ask spreads and fewer zeroreturn days. In addition, Acharya and Pedersen (2005) and Brunnermeier and Pedersen (2009) find that variability of liquidity tends to be higher for firms with greater opacity, especially during the 2007-2009 crisis period.

Based on the existing literature, we propose the first hypothesis of this study:

H1. Bank opacity, as measured by discretionary loan loss provisions, is positively related to stock trading illiquidity.

\subsubsection{Stock price crash risk}

Stock price crash refers to a large drop in stock price over a short period of time (Hong and Stein, 1999). Jin and Myers (2006) show that firm managers (or insiders) may conceal negative firm-specific information when the benefits of doing so outweigh the costs. However, managers are typically able to conceal only a limited amount of negative firm-specific information. When accumulated negative information reaches a critical threshold, managers find themselves in the position of having to release accumulated negative information to the public, resulting in an unexpected extreme negative stock return.

For firms with a high level of information asymmetry, firm-specific return distributions are more negatively skewed (Chen, Hong, and Stein, 2001). The negative 
skewness comes with a higher probability of a small positive return at the cost of a higher probability of an extreme negative return outlier in the return distribution (i.e., fatter left tails, see Figure 2-1). In other words, opaque firms are associated with more negativelyskewed return distributions.

\section{Figure 2-1 Negative skewness}

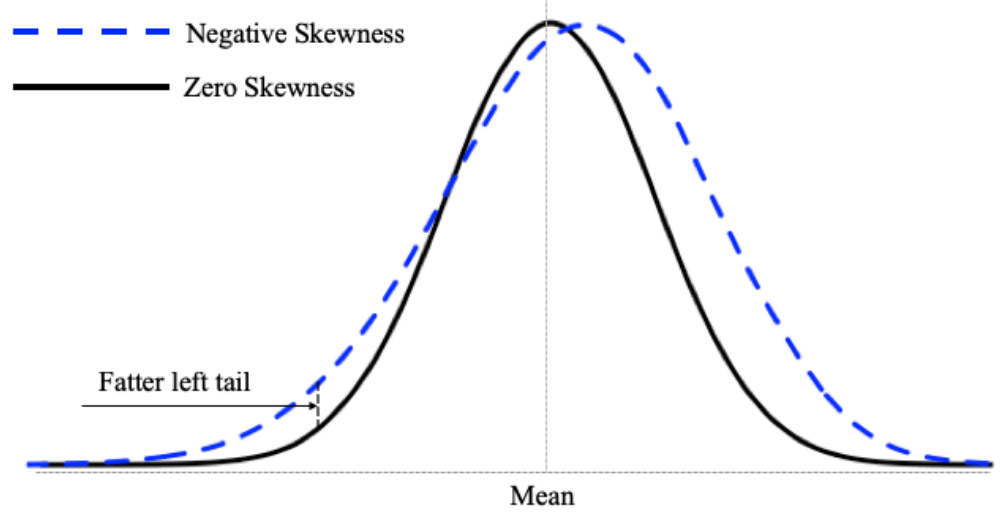

Consistent with the theory that negative-information-hoarding behavior induces $S P C R$, empirical evidence shows that financial transparency and accounting conservatism reduce future SPCR. For example, Jin and Myers (2006) find that overall firm opacity is associated with a higher probability of SPCR. Similarly, Hutton, Marcus, and Tehranian (2009), Kim and Zhang (2016), and Hung and Qiao (2017) find that accounting conservatism is associated with a lower probability of SPCR. In the banking sector, Cohen, Cornett, Marcus, and Tehranian (2014) find that banks with aggressive overall earnings management before 2007 were more likely to experience extremely negative stock returns during the crisis.

Based on previous theory and empirical evidence, our second hypothesis is: 
H2. Banks' opacity, as measured by discretionary loan loss provisions, is positively related to stock price crash risk.

\subsection{Empirical strategy}

\subsubsection{Discretionary loan loss provisions and stock trading illiquidity}

In this study, we use three STI measures: bid-ask spread, Amihud (2002)'s stock trading illiquidity measure, and the zero-return measure.

Market microstructure theory suggests that when trading volume is low, the inventory cost per trade is high. To compensate for the inventory cost of holding stocks, traders may purchase stocks at a bid price that is below the true price ${ }^{10}$, and sell stocks at an ask price that is above the true price (Ho and Stoll, 1980). So, the bid-ask spread is a proxy of trading inventory cost per trade. High $S T I$ is associated with a high bid-ask spread. Therefore, our first measure of $S T I$ is the bid-ask spread.

We use daily closing bid-ask spreads from the Center for Research in Security Prices (CRSP) database to capture STI. A large amount of the market microstructure literature calculates bid-ask spread relying on high-frequency data from the Trade and Quote (TAQ) database, which is a more precise way to capture market microstructure properties. Chung and Zhang (2014) find that, in the context of monthly average spreads, low frequency (daily) CRSP-based bid-ask spreads can be used as a viable alternative to high-frequency TAQ-based bid-ask spreads because the lowest correlation coefficients between CRSP and TAQ spreads is 0.91 for NASDAQ stocks and 0.82 for NYST/AMES stocks. Due to data limitations, we use Chung and Zhang (2014)'s CRSP-based daily bid-

\footnotetext{
${ }^{10}$ This is the terminology used in Ho and Stoll, 1980.
} 
ask spread measure. The bid-ask spread measure for stock $i$ in quarter $t$ is calculated pursuant to equation (6):

$$
\text { BidAsk }_{i, t}=\left(\frac{1}{D_{i, t}}\right) \sum_{d} \frac{\text { Ask price }_{i, d, t}-\text { Bid price }_{i, d, t}}{\left(\text { Ask price }_{i, d, t}+\text { Bid price }_{i, d, t}\right) / 2},
$$

where $D_{i, t}$ is the number of valid observation days for bank stock $i$ in quarter $t$, Ask $_{\text {price }} i, d, t$ is the closing ask price of bank stock $i$ on day $d$ in quarter $t$ from the CRSP daily data, and Bid price $e_{i, \mathrm{~d}, t}$ is the closing bid price of bank stock $i$ on day $d$ in quarter $t$ from CRSP daily data. For each bank, we calculate the quarterly average of the bid-ask spread. We expect that high $S T I$ is associated with a high value in BidAsk.

The second measure of bank STI is Amihud (2002)'s illiquidity measure. This measure captures stock price response to transaction volume. The intuition is that if a stock has a deep and liquid market, the stock price will not move much per dollar of daily trading volume. This is because liquidity and a deep market have the ability to absorb transaction quantities without having a large impact on stock price. This liquidity feature is known as price impact (Kyle, 1985; Amihud, 2002). In this study, we follow Amihud (2002) to calculate stock trading using equation (7). The Amihud illiquidity measure for stock $i$ in quarter $t$ is calculated as:

$$
\operatorname{Amihud}_{i, t}=1,000,000 \times\left(\frac{1}{D_{i, t}}\right) \sum_{d} \frac{\left|r_{i, d, t}\right|}{V o l_{i, d, t}}
$$


where $D_{i t}$ is the number of valid observation days for bank stock $i$ during quarter $t,\left|r_{i, d, t}\right|$ is the absolute value of return on bank stock $i$ on day $d$ in quarter $t$, and $V o l_{i, d, t}$ is the trading volume in U.S. dollars of bank stock $i$ on day $d$ in quarter $t$, obtained by multiplying the number of shares of a stock sold by the closing price. For each bank, we calculate the quarterly average of the Amihud illiquidity. To avoid unworkably small Amihud values, we multiply each calculated value by $1,000,000$.

Intuitively, for the same dollar amount of trading, if there is a large change in price, the stock is considered as illiquid. High STI is associated with a high Amihud value.

Third, we use the zero-return day ratio measure for illiquidity following Lang, Lins, and Maffett (2012). The zero-return day ratio $\left(Z E R O_{i, t}\right)$ is measured as the ratio of bank $i$ 's zero-return trading days over the bank's total trading days in the quarter $t$. Lesmond, Ogden, and Trzinka (1999) suggest that infrequent trading should be reflected in days without price movement. So, a high $Z E R O_{i, t}$ value means greater illiquidity.

Overall, we expect the STI, as measured by stock price BidAsk, Amihud, and ZERO respectively, to be positively related to the level of $D L L P$. To estimate the relation between DLLP and STI (see H1), we estimate regression (8):

$$
\begin{aligned}
& \text { STI }_{i, t}=\alpha_{0}+\alpha_{1} \text { DLLP }_{i, t-1}+\alpha_{2} \text { ROA }_{i, t-1}+\alpha_{3} \text { SIZE }_{i, t-1}+\alpha_{4} \text { TIER }_{i, t-1}+ \\
& \alpha_{5} \text { Loan }_{i, t-1}+\alpha_{6} \text { Depo }_{i, t-1}+\alpha_{7} \text { MTB }_{i, t-1}+\alpha_{8} \text { Turnover }_{i, t}+\alpha_{9} \text { RET }_{i, t}+ \\
& \alpha_{10} \text { RET_Vol }_{i, t}+\alpha_{11} \text { Price }_{i, t}+\alpha_{12} \text { VIX }_{t}+\alpha_{13} \text { SPRET }_{t}+\text { Quarter dummy }_{\text {dum }}+\varepsilon_{t}
\end{aligned}
$$

where $S T I_{i, t}$ is the illiquidity measure for bank $i$ at quarter $t$. The dependent variable is measured by BidAsk $_{i, t}$, Amihud $_{i, t}$, and $Z E R O_{i, t}$ respectively as described above. 
Market participants react to observed DLLP and other bank fundamental information. Therefore, we use the lagged variable $D L L P_{i, t-1}$. Using lagged variable also helps to control for the potential causality problem. For the other control variables in equation (8), we include a set of lagged bank fundamental variables following Bushman and Williams (2015). We also include a typical set of stock trading liquidity controls following Ding and Hou (2015).

Among the bank fundamental control variables, $R O A$ is calculated as income before extraordinary items divided by total assets. This variable is included to control for banks' profitability. The total book value of assets (SIZE) is calculated as the natural logarithm of total assets. This variable is included to control for banks' size. Tier-1 capital ratio (Tier1) is included to control for banks' capital ratios. The loan growth rate ( $\triangle$ Loan $)$ is calculated as the percentage change in loans over the quarter. This variable is included to control for the fact that high growth banks are different from low growth banks because the former may be taking on new, riskier loans. The Deposit-to-Loan ratio (Depo) is calculated total deposits divided by total loans. This variable is included to control for banks' access to deposit financing for their loans. Market-to-book ratio $(M T B)$ is calculated as the ratio of the market value of equity to the book value of equity, where market value is calculated as the common shares outstanding times the price at the end of the quarter. This variable is included to control for banks' growth opportunity.

Among the trading control variables, share turnover (Turnover), which is calculated as the natural logarithm of the quarterly average of the traded share volume divided by shares outstanding. This variable is included to control for trading volume. Average quarterly returns $(R E T)$ is calculated as the quarterly average of the daily stock returns. 
Return volatility $\left(R E T \_V o l\right)$ is calculated as the standard deviation of daily stock returns over the quarter. Average share price over the quarter (Price) is calculated as the average price of the stock over the quarter. It captures the probability that investors have a preference to buy stocks within a certain price range.

We include two market control variables. VIX is the average value of CBOE Volatility Index over the quarter. This variable is included to account for the overall market volatility. SPRET is the average daily return on the S\&P Composite Index over the quarter. This variable is included to account for the overall market return.

When estimating equation (8), we use an individual fixed effect model (also called a firm fixed effect model) to control for the issue that some omitted variables may be correlated with the variables in the model. ${ }^{11}$ The individual fixed effect model removes the effect of those time-invariant (but individual varying) characteristics. The idea is that if the omitted variables have some effect on the variables in the model at one time, they will also have the same effects at a later time. So, their effects over time should be fixed. Individual fixed effect models can remove the time-invariant values, so we can assess the net effect of the independent variables on the dependent variable. In addition, to control for the influence of aggregate time trends over quarters, we add time fixed effects by adding quarter time dummies.

As mentioned in Section 2.2.1, because the $S T I$ can be influenced by more than one period's $D L L P$ practice, we also examine the accumulated DLLP (ADLLP) on STI. We repeat the analysis by replacing $D L L P$ with $A D L L P$ as shown in equation (9):

\footnotetext{
${ }^{11}$ We perform the Hausman test to determine whether to use random effects or fixed effects (Greene, 2003). The test result indicates that the firm fixed effects model is preferred.
} 


$$
\begin{aligned}
& \text { STI }_{i, t}=\alpha_{0}+\alpha_{1} \text { ADLLP }_{i, t-1}+\alpha_{2} \text { ROA }_{i, t-1}+\alpha_{3} \text { SIZE }_{i, t-1}+\alpha_{4} \text { TIER }_{i, t-1}+ \\
& \alpha_{5} \text { LLan }_{i, t-1}+\alpha_{6} \text { Depo }_{i, t-1}+\alpha_{7} \text { MTB }_{i, t-1}+\alpha_{8} \text { Turnover }_{i, t}+\alpha_{9} R E T_{i, t}+ \\
& \alpha_{10} \text { RET_Vol }_{i, t}+\alpha_{11} \text { Price }_{i, t}+\alpha_{12} \text { VIX }_{t}+\alpha_{13} \text { SPRET }_{t}+\text { Quarter dummy }+\varepsilon_{t}
\end{aligned}
$$

\subsubsection{Discretionary loan loss provisions and stock price crash risk}

As discussed in Section 2.2.3, a high level of bad news hoarding can lead to extreme negative bank-specific returns over a short period of time (e.g., a few days) if all (or most of) the hoarded news was to become known to the public all at once. The risk that this might happen is called stock price crash risk.

We use negative skewness of firm-specific weekly returns to measure stock price crash risk following Chen, Hong, and Stein (2001). Negative skewness comes with a higher probability of a small positive return at the cost of a higher probability of an extreme negative return. So, a bank with a highly negatively skewed returns distribution is interpreted as a bank that is more likely to experience stock price crashes. Following the

literature, we use -1 times the third moment of each bank's return $R_{i, t}$ to capture negative skewness:

$$
N S K E W_{i, t}=-\frac{n(n-1)^{3 / 2} \sum R_{i, t}^{3}}{(n-1)(n-2)\left(\sum R_{i, t}^{2}\right)^{3 / 2}}
$$

where $R_{i, t}$ is the firm-specific weekly return for bank $i$ in year $t$, and $n$ is the number of weekly return observations for bank $i$ in year $t$. A higher value of NSKEW for a bank implies 
a more left-skewed return distribution, and correspondingly, that the bank in question is more likely to experience stock price crashes.

In equation (10), bank-specific return $R_{i, t}$ refer to the returns after netting out the portion of returns attributed by common market factors and bank-industry effects. We start with estimation of equation (11) in which $R_{i, t}$ is captured by $\varepsilon_{i, t}$ :

$$
\begin{aligned}
& r_{i, t}=\alpha_{j}+\beta_{1} r_{m, t-2}+\beta_{2} r_{m, t-1}+\beta_{3} r_{m, t}+\beta_{4} r_{m, t+1}+\beta_{5} r_{m, t+2}+\beta_{6} r_{b, t-2}+\beta_{7} r_{b, t-1}+ \\
& \beta_{8} r_{b, t}+\beta_{9} r_{b, t+1}+\beta_{10} r_{b, t+2}+\varepsilon_{i, t}
\end{aligned}
$$

where $r_{i, t}$ is the stock return on bank $i$ on week $t, r_{m, t}$ is the CRSP value-weighted market index return on week $t$, and $r_{b, t}$ is the value-weighted return bank-industry index return on week $t$ (provided by Kenneth R. French's data library). Consistent with Cohen, Cornett, Marcus, and Tehranian (2014), we include two lead terms and two lag terms for the market and bank industry average returns to allow for nonsynchronous trading. The residual $\varepsilon_{i, t}$ captures bank-specific returns $R_{i, t}$ for bank $i$ on week $t$.

Next, we examine the relation between the level of DLLP and NSKEW using equation (12) with a firm and time-fixed effect regression model:

$$
\begin{aligned}
& \text { NSKEW }_{i, t}=\alpha_{0}+\alpha_{1} \text { DLLP }_{i, t-1}^{\prime}+\alpha_{2} \text { ROA }_{i, t-1}+\alpha_{3} \text { SIZE }_{i, t-1}+\alpha_{4} \text { TIER }_{i, t-1}+ \\
& \alpha_{5} \text { Loan }_{i, t-1}+\alpha_{6} \text { Depo }_{i, t-1}+\alpha_{7} \text { MTB }_{i, t-1}+\alpha_{8} \text { Turnover }_{i, t}+\alpha_{9} \text { RET }_{i, t}+ \\
& \alpha_{10} \text { RET_Vol }_{i, t}+\alpha_{11} \text { Price }_{i, t}+\alpha_{12} \text { BidAs }_{i, t}+\alpha_{13} \text { VIX }_{t}+\alpha_{14} \text { SPRET }_{t}+ \\
& \text { Yeardummy }+\varepsilon_{t} .
\end{aligned}
$$


Unlike our tests of the relationship between $S T I$ and $D L L P$, where we used bankquarter observations, we perform the current analysis using the bank-year observations following the prior literature. Stock price crashes tend to be very rare events. If we were to study stock price crashes using quarterly, or more frequent, data, the dependent variable might not exhibit sufficient variation. In model (12), the dependent variable $N S K E W_{i, t}$ is the return distribution skewness for bank $i$ in the year preceding each bank-year observation $t$, which is calculated using equation (10).

The main explanatory variable of interest, $D L L P^{\prime}{ }_{i, t-1}$, is defined as the sum of the 4 quarters' $D L L P$ in year $t-1$ :

$$
D L L P_{i, t-1}^{\prime}=D L L P_{i, t-1, Q 1}+D L L P_{i, t-1, Q 2}+D L L P_{i, t-1, Q 3}+D L L P_{i, t-1, Q 4} .
$$

where the $D L L P_{i, t, Q 1}$ is the $D L L P$ for bank $i$ in $\mathrm{Q} 1$ in year $t, D L L P_{i, t-1, Q 2}$ is the $D L L P$ for bank $i$ in Q2 in year $t$, and so on. The quarterly $D L L P$ is calculated using the method introduced in Section 2.2.1 (i.e., the absolute value of residuals of the LLP models). With this method, we can test whether the $S P C R$ is related to banks' accumulated $D L L P$ practice during the past year.

Insofar as other control variables are concerned, we included all controls from models (8) and (9). The bank fundamental control variables are lagged by one year. In addition, Chang, Chen, and Zolotoy (2017) suggest that managers in firms with greater stock liquidity are more likely to withhold bad news because managers fear that its disclosure could lead to selling by transient investors. Therefore, the stock price crash risk 
may be affected by stock trading liquidity. Accordingly, we add a stock liquidity control 'BidAsk $k_{i, t}$ ', which is calculated as the average bid-ask spreads in year $t$.

\subsection{Data and empirical results}

\subsubsection{Sample selection}

Our sample consists of all publicly traded U.S. commercial banks or bank holding companies regulated by Federal Reserve over the sample period 2000Q1-2016Q4. We obtain our bank accounting data from the Compustat Bank database and we obtain the stock trading data from the Center for Research in Security Price (CRSP) database. All the macro-level variables are obtained from FRED, which is the economic database maintained by the St. Louis Federal Reserve.

Our initial sample includes 2,144,711 bank-day observations for the stock trading variables' estimation, 29,827 bank-quarter observations for the bank quarterly fundamental variables' estimation, and 8,456 bank-year observation for the bank annual fundamental variables' estimation. ${ }^{12}$ Following Beatty and Liao (2011), we exclude all observations with non-loan asset growth rate exceeding $10 \%$ in any quarter to exclude the influence from mergers and acquisitions. We also exclude observations with missing values in computing the required variables in regressions. The final sample size and variables' summary statistics are reported in Table 2-7 and Table 2-13 respectively.

\footnotetext{
12 There is a concern about exposure to the "Type 1 error" problem due the large sample size. To address this concern, in the unreported additional tests, we slice the sample based on the bank size and re-estimate the baseline regressions. The main findings are robust when using the sub-samples.
} 
Appendix B lists the detailed variable definition, calculation methods, and data source. To reduce potential bias from outliers, all continuous variables in regression analysis are winsorized at the $1 \%$ and $99 \%$ level.

\subsubsection{Discretionary loan loss provisioning: the estimation results}

We first estimate LLP model (1) - (4) to obtain the DLLP measures. Table 2-4 reports the regression results of the predictors in the four LLP models. The estimation results, including the coefficient significance and the $\mathrm{R}^{2}$ of each model, are very close to the results as reported in Beatty and Liao (2014).

Table 2-4 Regression results of loan loss provision models

Dependent Variable: $L L P_{i, t}$

(Intercept)

$\triangle N P A_{i, t+1}$

$\triangle N P A_{i, t}$

$\triangle N P A_{i, t-1}$

$\triangle N P A_{i, t-2}$

$\operatorname{SIZE}_{i, t-1}$

$\triangle L O A N_{i, t}$

$\operatorname{CSRET}_{t}$

$\triangle U N E M P_{t}$

$\triangle G D P_{t}$

$\mathrm{CO}_{i, t}$

$A L W_{i, t-1}$

No. of obs.

Adj. R-Squared

0.214

Notes: This table presents the regression estimating results of LLP models (1) to (4). Appendix B provides all the variable definitions and data sources. Each column reports the coefficient estimates and t-statistics (in parentheses) of each model. All regression models are estimated with OLS. The sample period is 2000Q1 to 2016Q4.

$* * *, * *$, and $*$ represent $1 \%, 5 \%$, and $10 \%$ significance, respectively.

All the coefficients of all bank-level predictors are significant at 1\% level. Model
(1)

(2)

(3)

(4)

$$
0.014 * * *(4.598)
$$

$0.075 * * *(24.401)$

$0.083 * * *(27.046)$

$0.094 * * *(30.648)$

$0.000 * * *(13.512)$

$-0.010 * * *(-31.158)$

$-0.009 * * *(-11.456)$

$0.002 * * *(5.384)$

$-0.006 *(-1.952)$

$-0.870 * * *(-204.737)$

$0.148 * * *(74.366)$

24138

23698

$-0.001 * * *(-16.142)$

$0.000 * * *$ ( 5.024$)$

$0.029 * * *(15.789)$

$0.083 * * *$ ( 44.370 )

$0.032 * * *(16.719)$

$0.028 * * *(15.014)$

$0.000 * *$ ( 2.495$)$

$0.000(-1.354)$

$0.000(-0.455)$

$0.002 * * *(10.781)$

$-0.005 * *(-2.512)$

$-0.879 * * *(-172.222)$

$-0.005 * * *(-3.343)$

23696

0.717 
the exercise of the discretion in charge-offs is highly correlated with the exercise of discretion in loan loss provisions (Liu and Ryan, 2006; Beatty and Liao, 2014), the two models with $C O$ as a predictor show better explanatory power.

The residuals $\varepsilon_{i, t}=L L P_{i, t}-\widehat{L P P}_{i, t}$ from each model represent the unexplained component of loan loss provisions. So, the measure of $D L L P$ of bank $i$ at quarter $t$ is $D L L P_{i, t}=\left|\varepsilon_{i, t}\right|$. Following this method, we obtain $D L L P 1, D L L P 2, D L L P 3$, and DLLP4 from models (1) to (4) respectively.

To examine if the DLLPs generated from the four models are correlated with each other, we report the correlation matrix of the four DLLP measures in Table 2-5. Overall, the correlation matrix suggests that the four DLLP measures are closely related to each other. DLLP1 is highly correlated with $D L L P 3 . D L L P 2$ is highly correlated with $D L L P 4$. The weakest correlation is found between $D L L P 1$ and DLLP4. The correlation coefficient between these two DLLP measures is 0.6 , which still signals a high correlation.

Table 2-5 Correlation matrix of the four $D L L P$ measures

\begin{tabular}{ccccc}
\hline & $D L L P 1$ & $D L L P 2$ & $D L L P 3$ & DLLP4 \\
\hline DLLP1 & 1.000 & 0.601 & 0.903 & 0.601 \\
$D L L P 2$ & 0.601 & 1.000 & 0.675 & 1.000 \\
$D L L P 3$ & 0.903 & 0.675 & 1.000 & 0.666 \\
$D L L P 4$ & 0.601 & 1.000 & 0.666 & 1.000 \\
\hline
\end{tabular}

Notes: The table presents the correlation coefficients of four DLLP measures generated from LLP models (1) to (4). $D L L P_{i, t}=\left|\varepsilon_{i, t}\right|$, where $\varepsilon_{i, t}$ is the absolute value of residuals from model (1) in Table 2-1. Similarly, $D L L P 2_{i, t}, D L L P 3_{i, t}$ and $D L L P 4_{i, t}$ are the absolute value of residuals from model (2), (3), and (4).

We further compute the accumulated $D L L P(A D L L P)$ measures using equation (5). We report the correlation coefficients of the four ADLLP measures in Table 2-6. The correlation coefficients of the four $A D L L P$ measures suggest that the four $A D L L P$ measures 
are closely related to each other. $A D L L P 1$ is highly correlated with $A D L L P 3$, and $A D L L P 2$ is highly correlated with $A D L L P 4$.

Table 2-6 Correlation matrix of the four $A D L L P$ measures

\begin{tabular}{rrrrr}
\hline & ADLLP1 & ADLLP2 & ADLLP3 & ADLLP4 \\
\hline ADLLP1 & 1.000 & 0.703 & 0.876 & 0.704 \\
$A D L L P 2$ & 0.703 & 1.000 & 0.765 & 1.000 \\
$A D L L P 3$ & 0.876 & 0.765 & 1.000 & 0.759 \\
ADLLP4 & 0.704 & 1.000 & 0.759 & 1.000 \\
\hline
\end{tabular}

Notes: The table presents the correlation coefficients of four $A D L L P$ measures.

\subsubsection{Empirical results for the relation between $D L L P($ and $A D L L P)$ and $S T I$}

\subsubsection{The summary statistics and correlation coefficients of the main variables}

Table 2-7 reports the summary statistics for the variables to be used in the regression tests on the relation between $D L L P$ (and $A D L L P$ ) and $S T I$. The sample period is from 2000Q1 to 2016Q4. Column 1 reports the number of bank-quarter observations after excluding observations with missing values. Column 2 and Column 3 report the mean and standard deviations, respectively. Column $4-6$ report the sample quantiles as $25 \%, 50 \%$ (median), and $75 \%$, respectively. The descriptive statistics show that the $4 D L L P$ measures are quite close with a mean value around 0.001 .

Table 2-8 reports the correlation coefficients of all the $D L L P($ and $A D L L P)$ and $S T I$ measures. The correlation matrix shows that all the $D L L P($ and $A D L L P)$ and $S T I$ measures are positively correlated with each other, consistent with the notion that firms with higher opacity are associated with higher stock illiquidity. The two STI measures, BidAsk and Amihud, are highly correlated with each other with a correlation coefficient of 0.881 . 
Table 2-7 Descriptive statistics based on bank-quarter observations between 2000Q1 to 2016Q4

\begin{tabular}{|c|c|c|c|c|c|c|}
\hline & $\mathrm{N}$ & Mean & Std.Dev & $25 \%$ quantile & Median & $75 \%$ quantile \\
\hline BidAsk & 24105 & 0.014 & 0.018 & 0.002 & 0.007 & 0.018 \\
\hline Amihud & 24133 & 1.192 & 2.752 & 0.008 & 0.078 & 1.004 \\
\hline ZERO & 24133 & 0.051 & 0.056 & 0.016 & 0.032 & 0.078 \\
\hline$D L L P 1$ & 20309 & 0.001 & 0.002 & 0.001 & 0.001 & 0.002 \\
\hline DLLP2 & 19965 & 0.001 & 0.001 & 0.000 & 0.000 & 0.001 \\
\hline DLLP3 & 20303 & 0.001 & 0.002 & 0.000 & 0.001 & 0.001 \\
\hline DLLP4 & 19963 & 0.001 & 0.001 & 0.000 & 0.000 & 0.001 \\
\hline$A D L L P 1$ & 18143 & 0.006 & 0.006 & 0.003 & 0.004 & 0.007 \\
\hline$A D L L P 2$ & 17701 & 0.003 & 0.004 & 0.001 & 0.002 & 0.004 \\
\hline ADLLP3 & 18136 & 0.005 & 0.005 & 0.002 & 0.003 & 0.006 \\
\hline ADLLP4 & 17697 & 0.003 & 0.004 & 0.001 & 0.002 & 0.004 \\
\hline $\mathrm{ROA}$ & 24132 & 0.002 & 0.003 & 0.001 & 0.002 & 0.003 \\
\hline SIZE & 24133 & 7.661 & 1.470 & 6.613 & 7.320 & 8.399 \\
\hline TIER1 & 21934 & 12.115 & 3.281 & 9.930 & 11.640 & 13.720 \\
\hline$\Delta L o a n$ & 24121 & 0.019 & 0.040 & -0.003 & 0.015 & 0.036 \\
\hline Depo & 24116 & 1.192 & 0.302 & 1.017 & 1.132 & 1.298 \\
\hline$M T B$ & 24064 & 1.435 & 0.684 & 0.962 & 1.311 & 1.814 \\
\hline Turnover & 24125 & 2.725 & 3.149 & 0.792 & 1.633 & 3.349 \\
\hline RET & 24133 & 0.000 & 0.002 & -0.001 & 0.001 & 0.002 \\
\hline RET_vol & 24133 & 0.021 & 0.011 & 0.013 & 0.018 & 0.025 \\
\hline Price & 24133 & 20.462 & 13.622 & 11.075 & 17.534 & 26.708 \\
\hline VIX & 24133 & 19.920 & 7.723 & 14.098 & 18.204 & 23.924 \\
\hline SPRET & 24133 & 0.000 & 0.001 & 0.000 & 0.000 & 0.001 \\
\hline
\end{tabular}

Notes: This table reports the descriptive statistics based on all bank-quarter observations for testing the relation between $D L L P$ (and $A D L L P$ ) and STI. Column 1 reports the number of observations (excluding missing values). Column 2 and Column 3 report the mean and standard deviations, respectively. Column 4 -6 report the quantiles as $25 \%, 50 \%$ (median), and $75 \%$, respectively.

The sample period is from 2000Q1 to 2016Q4. All variables are calculated as defined in Appendix B. 
Table 2-8 Correlation matrix for testing the relation between $D L L P($ and $A D L L P)$ and $S T I$

\begin{tabular}{lccccccccccc}
\hline & BidAsk & Amihud & ZERO & DLLP1 & DLLP2 & DLLP3 & DLLP4 & ADLLP1 & ADLLP2 & ADLLP3 & ADLLP4 \\
\hline BidAsk & 1.000 & 0.881 & 0.402 & 0.190 & 0.254 & 0.211 & 0.254 & 0.227 & 0.325 & 0.259 & 0.325 \\
Amihud & 0.881 & 1.000 & 0.337 & 0.184 & 0.238 & 0.203 & 0.238 & 0.231 & 0.316 & 0.263 & 0.316 \\
ZERO & 0.402 & 0.337 & 1.000 & 0.050 & 0.097 & 0.067 & 0.097 & 0.083 & 0.140 & 0.103 & 0.140 \\
DLLP1 & 0.190 & 0.184 & 0.050 & 1.000 & 0.599 & 0.879 & 0.599 & 0.723 & 0.518 & 0.633 & 0.519 \\
DLLP2 & 0.254 & 0.238 & 0.097 & 0.599 & 1.000 & 0.650 & 1.000 & 0.485 & 0.705 & 0.529 & 0.705 \\
DLLP3 & 0.211 & 0.203 & 0.067 & 0.879 & 0.650 & 1.000 & 0.643 & 0.616 & 0.557 & 0.718 & 0.553 \\
DLLP4 & 0.254 & 0.238 & 0.097 & 0.599 & 1.000 & 0.643 & 1.000 & 0.485 & 0.704 & 0.524 & 0.704 \\
ADLLP1 & 0.227 & 0.231 & 0.083 & 0.723 & 0.485 & 0.616 & 0.485 & 1.000 & 0.698 & 0.868 & 0.699 \\
ADLLP2 & 0.325 & 0.316 & 0.140 & 0.518 & 0.705 & 0.557 & 0.704 & 0.698 & 1.000 & 0.760 & 1.000 \\
ADLLP3 & 0.259 & 0.263 & 0.103 & 0.633 & 0.529 & 0.718 & 0.524 & 0.868 & 0.760 & 1.000 & 0.754 \\
ADLLP4 & 0.325 & 0.316 & 0.140 & 0.519 & 0.705 & 0.553 & 0.704 & 0.699 & 1.000 & 0.754 & 1.000 \\
\hline
\end{tabular}

Notes: This table reports the correlation matrix of the major variables of interest for testing the relation between $D L L P$ (and $A D L L P$ ) and STI. All variables are calculated as defined in Appendix B.

\subsubsection{The baseline regression results}

In this section, we test the relation between $D L L P($ and $A D L L P$ ) and $S T I$. We first report the baseline regression estimation results of equation (8) and (9).

Tables 2-9, 2-10, and 2-11 report the regression results for the relation between DLLP and STI as measured by Amihud, BidAsk, and ZERO, respectively. Each table includes two panels. Panel A reports the regression results of equation (8), where $D L L P$ is measured by one-period DLLP. Column (1) to (4) in Panel A reports the regression results when the one-period $D L L P$ is measured by DLLP1, DLLP2, DLLP3, and DLLP4 respectively. Panel B reports the regression results of equation (9), where DLLP is measured by accumulated $D L L P(A D L L P)$. Column (1) to (4) in Panel B reports the regression results when $A D L L P$ is measured by $A D L L P 1, A D L L P 2, A D L L P 3$, and $A D L L P 4$ respectively. 
Table 2-9 The regression results for the relation between $D L L P$ and $A m i h u d$

\begin{tabular}{|c|c|c|c|c|}
\hline \multicolumn{5}{|c|}{ Dependent variable: Amihud } \\
\hline \multicolumn{5}{|c|}{ Panel A: Using DLLP as the independent variable } \\
\hline & (1) & (2) & (3) & (4) \\
\hline$D L L P 1$ & $9.271(1.248)$ & & & \\
\hline$D L L P 2$ & & $43.426 * * *(4.241)$ & & \\
\hline$D L L P 3$ & & & $19.851 * * *(2.577)$ & \\
\hline$D L L P 4$ & & & & $43.270 * * *(4.224)$ \\
\hline$R O A$ & $-2.105(-0.328)$ & $0.556(0.099)$ & $1.008(0.165)$ & $0.521(0.092)$ \\
\hline$S I Z E$ & $-0.555 * * *(-10.314)$ & $-0.519 * * *(-9.607)$ & $-0.553 * * *(-10.264)$ & $-0.519 * * *(-9.608)$ \\
\hline TIER 1 & $-0.064 * * *(-11.141)$ & $-0.064 * * *(-11.164)$ & $-0.064 * * *(-11.218)$ & $-0.064 * * *(-11.162)$ \\
\hline$\Delta$ Loan & $-0.478 * *(-2.069)$ & $-0.431 *(-1.862)$ & $-0.471 * *(-2.042)$ & $-0.43 *(-1.858)$ \\
\hline Depo & $-0.043(-0.565)$ & $-0.017(-0.229)$ & $-0.045(-0.589)$ & $-0.018(-0.240)$ \\
\hline$M T B$ & $-0.531 * * *(-15.244)$ & $-0.542 * * *(-15.488)$ & $-0.532 * * *(-15.272)$ & $-0.542 * * *(-15.486)$ \\
\hline Turnover & $-0.234 * * *(-40.298)$ & $-0.231 * * *(-39.977)$ & $-0.234 * * *(-40.334)$ & $-0.231 * * *(-39.973)$ \\
\hline$R E T$ & $-30.837 * * *(-5.648)$ & $-31.364 * * *(-5.742)$ & $-30.563 * * *(-5.597)$ & $-31.355 * * *(-5.740)$ \\
\hline RET_vol & $106.049 * * *(54.632)$ & $104.564 * * *(53.476)$ & $105.920 * * *(54.550)$ & $104.568 * * *(53.476)$ \\
\hline Price & $0.012 * * *(5.827)$ & $0.012 * * *(6.017)$ & $0.012 * * *(5.893)$ & $0.012 * * *(6.015)$ \\
\hline$V I X$ & $-0.330 * *(-2.318)$ & $-0.328 * *(-2.314)$ & $-0.330 * *(-2.318)$ & $-0.328 * *(-2.316)$ \\
\hline SPRET & $-1072.749(-1.552)$ & $-1076.597(-1.566)$ & $-1072.895(-1.552)$ & $-1078.079(-1.568)$ \\
\hline No. of obs. & 18899 & 18676 & 18896 & 18674 \\
\hline Adj. R-Squared & 0.285 & 0.281 & 0.285 & 0.281 \\
\hline Time fixed effects & Yes & Yes & Yes & Yes \\
\hline Firm fixed effects & Yes & Yes & Yes & Yes \\
\hline \multicolumn{5}{|c|}{ Panel B: Using ADLLP as the independent variable } \\
\hline & (1) & (2) & (3) & (4) \\
\hline$A D L L P 1$ & $13.063 * * *(5.006)$ & & & \\
\hline$A D L L P 2$ & & $22.076 * * *(5.027)$ & & \\
\hline$A D L L P 3$ & & & $17.698 * * *(6.159)$ & \\
\hline$A D L L P 4$ & & & & $22.024 * * *(5.010)$ \\
\hline$R O A$ & $6.676(1.166)$ & $2.445(0.446)$ & $7.132(1.266)$ & $2.454(0.448)$ \\
\hline$S I Z E$ & $-0.490 * * *(-8.700)$ & $-0.420 * * *(-7.445)$ & $-0.479 * * *(-8.499)$ & $-0.421 * * *(-7.448)$ \\
\hline TIER1 & $-0.067 * * *(-11.375)$ & $-0.066 * * *(-11.154)$ & $-0.068 * * *(-11.562)$ & $-0.066 * * *(-11.149)$ \\
\hline$\Delta$ Loan & $-0.41 *(-1.736)$ & $-0.416 *(-1.76)$ & $-0.433 *(-1.833)$ & $-0.415 *(-1.756)$ \\
\hline Depo & $0.004(0.053)$ & $0.049(0.619)$ & $-0.001(-0.010)$ & $0.047(0.600)$ \\
\hline$M T B$ & $-0.520 * * *(-14.435)$ & $-0.532 * * *(-14.665)$ & $-0.518 * * *(-14.377)$ & $-0.532 * * *(-14.666)$ \\
\hline Turnover & $-0.215 * * *(-37.130)$ & $-0.212 * * *(-36.741)$ & $-0.215 * * *(-37.066)$ & $-0.212 * * *(-36.735)$ \\
\hline$R E T$ & $-33.004 * * *(-6.011)$ & $-32.333 * * *(-5.906)$ & $-32.380 * * *(-5.900)$ & $-32.342 * * *(-5.907)$ \\
\hline$R E T_{-}$vol & $97.115 * * *(48.101)$ & $94.948 * * *(46.555)$ & $96.790 * * *(47.941)$ & $94.956 * * *(46.555)$ \\
\hline Price & $0.013 * * *(6.082)$ & $0.013 * * *(6.152)$ & $0.013 * * *(6.358)$ & $0.013 * * *(6.137)$ \\
\hline$V I X$ & $-0.286 * *(-2.281)$ & $-0.282 * *(-2.274)$ & $-0.287 * *(-2.290)$ & $-0.282 * *(-2.274)$ \\
\hline SPRET & $3095.743 *(1.836)$ & $3083.836 *(1.852)$ & $3104.172 *(1.842)$ & $3085.364 *(1.853)$ \\
\hline No. of obs. & 17020 & 16690 & 17015 & 16687 \\
\hline Adj. R-Squared & 0.266 & 0.26 & 0.266 & 0.26 \\
\hline Time fixed effects & Yes & Yes & Yes & Yes \\
\hline Firm fixed effects & Yes & Yes & Yes & Yes \\
\hline
\end{tabular}

Notes: This table reports the regression results for the relation between discretionary loan loss provisioning and stock price illiquidity as measured by Amihud. Panel A of this table reports the regression results of equation (8), where the DLLP is measured by one-period DLLP. Column (1) to (4) in Panel A reports the regression results when the $D L L P$ is measured by $D L L P 1, D L L P 2, D L L P 3$, and $D L L P 4$ respectively. Panel $\mathrm{B}$ reports the regression results of equation (9), where the $D L L P$ is measured by accumulated $D L L P(A D L L P)$. Column (1) to (4) in Panel B reports the regression results when $A D L L P$ is measured by $A D L L P 1, A D L L P 2$, $A D L L P 3$, and $A D L L P 4$ respectively. Appendix B provides all the variable definitions and data sources. Each column reports the coefficient estimates and t-statistics (in parentheses) of each model. All regression models are estimated with both time-fixed and firm-fixed effect model. The sample period is from $2000 \mathrm{Q} 1$ to 2016Q4. ***,**, and * represent $1 \%, 5 \%$, and 10\% significance, respectively. 
Table 2-10 The regression results for the relation between $D L L P$ and BidAsk

\begin{tabular}{|c|c|c|c|c|}
\hline \multicolumn{5}{|c|}{ Dependent variable: BidAsk } \\
\hline \multicolumn{5}{|c|}{ Panel A: Using DLLP as the independent variable } \\
\hline & (1) & (2) & (3) & (4) \\
\hline$D L L P 1$ & $0.009(0.228)$ & & & \\
\hline$D L L P 2$ & & $0.049(0.924)$ & & \\
\hline$D L L P 3$ & & & $-0.028(-0.700)$ & \\
\hline$D L L P 4$ & & & & $0.051(0.959)$ \\
\hline$R O A$ & $-0.022(-0.671)$ & $-0.023(-0.789)$ & $-0.037(-1.168)$ & $-0.023(-0.778)$ \\
\hline$S I Z E$ & $-0.004 * * *(-13.381)$ & $-0.004 * * *(-12.613)$ & $-0.004 * * *(-13.384)$ & $-0.004 * * *(-12.609)$ \\
\hline TIER 1 & $0.000 * * *(-12.238)$ & $0.000 * * *(-12.096)$ & $0.000 * * *(-12.183)$ & $0.000 * * *(-12.097)$ \\
\hline$\Delta$ Loan & $-0.001(-1.018)$ & $-0.001(-0.917)$ & $-0.001(-1.039)$ & $-0.001(-0.915)$ \\
\hline Depo & $0.001 *(1.787)$ & $0.001 *(1.913)$ & $0.001 *(1.783)$ & $0.001 *(1.904)$ \\
\hline$M T B$ & $-0.003 * * *(-16.689)$ & $-0.003 * * *(-17.009)$ & $-0.003 * * *(-16.657)$ & $-0.003 * * *(-17.008)$ \\
\hline Turnover & $-0.002 * * *(-55.470)$ & $-0.002 * * *(-55.201)$ & $-0.002 * * *(-55.466)$ & $-0.002 * * *(-55.197)$ \\
\hline$R E T$ & $-0.124 * * *(-4.374)$ & $-0.130 * * *(-4.563)$ & $-0.125 * * *(-4.389)$ & $-0.130 * * *(-4.562)$ \\
\hline$R E T \_v o l$ & $0.762 * * *(75.315)$ & $0.755 * * *(74.025)$ & $0.763 * * *(75.338)$ & $0.755 * * *(74.020)$ \\
\hline Price & $0.000 * * *(3.851)$ & $0.000 * * *(3.860)$ & $0.000 * * *(3.845)$ & $0.000 * * *(3.862)$ \\
\hline$V I X$ & $-0.001(-1.137)$ & $-0.001(-1.106)$ & $-0.001(-1.137)$ & $-0.001(-1.107)$ \\
\hline SPRET & $-5.488(-1.523)$ & $-5.474(-1.526)$ & $-5.489(-1.523)$ & $-5.477(-1.527)$ \\
\hline No. of obs. & 18875 & 18652 & 18872 & 18650 \\
\hline Adj. R-Squared & 0.488 & 0.483 & 0.488 & 0.483 \\
\hline Time fixed effects & Yes & Yes & Yes & Yes \\
\hline Firm fixed effects & Yes & Yes & Yes & Yes \\
\hline \multicolumn{5}{|c|}{ Panel B: Using ADLLP as the independent variable } \\
\hline & $(1)$ & (2) & (3) & (4) \\
\hline$A D L L P 1$ & $0.076 * * *(5.511)$ & & & \\
\hline$A D L L P 2$ & & $0.069 * * *(2.959)$ & & \\
\hline$A D L L P 3$ & & & $0.065 * * *(4.264)$ & \\
\hline$A D L L P 4$ & & & & $0.070 * * *(2.973)$ \\
\hline$R O A$ & $0.019(0.629)$ & $-0.023(-0.776)$ & $-0.001(-0.023)$ & $-0.022(-0.769)$ \\
\hline$S I Z E$ & $-0.004 * * *(-11.884)$ & $-0.003 * * *(-10.614)$ & $-0.004 * * *(-11.730)$ & $-0.003 * * *(-10.616)$ \\
\hline TIER 1 & $0.000 * * *(-11.530)$ & $0.000 * * *(-11.216)$ & $0.000 * * *(-11.672)$ & $0.000 * * *(-11.211)$ \\
\hline$\Delta$ Loan & $-0.001(-0.790)$ & $-0.001(-1.006)$ & $-0.001(-0.997)$ & $-0.001(-0.999)$ \\
\hline Depo & $0.001(1.561)$ & $0.001 * *(2.085)$ & $0.001 *(1.657)$ & $0.001 * *(2.080)$ \\
\hline$M T B$ & $-0.003 * * *(-15.274)$ & $-0.003 * * *(-15.914)$ & $-0.003 * * *(-15.190)$ & $-0.003 * * *(-15.909)$ \\
\hline Turnover & $-0.002 * * *(-52.453)$ & $-0.002 * * *(-51.829)$ & $-0.002 * * *(-52.328)$ & $-0.002 * * *(-51.823)$ \\
\hline$R E T$ & $-0.149 * * *(-5.126)$ & $-0.145 * * *(-4.961)$ & $-0.145 * * *(-4.998)$ & $-0.145 * * *(-4.962)$ \\
\hline$R E T_{-}$vol & $0.718 * * *(67.263)$ & $0.713 * * *(65.585)$ & $0.720 * * *(67.400)$ & $0.713 * * *(65.579)$ \\
\hline Price & $0.000 * * *(4.286)$ & $0.000 * * *(4.370)$ & $0.000 * * *(4.356)$ & $0.000 * * *(4.352)$ \\
\hline$V I X$ & $-0.001(-1.013)$ & $-0.001(-1.041)$ & $-0.001(-1.044)$ & $-0.001(-1.041)$ \\
\hline SPRET & $11.233(1.260)$ & $11.548(1.302)$ & $11.459(1.285)$ & $11.545(1.302)$ \\
\hline No. of obs. & 17007 & 16677 & 17002 & 16674 \\
\hline Adj. R-Squared & 0.467 & 0.461 & 0.467 & 0.461 \\
\hline Time fixed effects & Yes & Yes & Yes & Yes \\
\hline Firm fixed effects & Yes & Yes & Yes & Yes \\
\hline
\end{tabular}

Notes: This table reports the regression results for the relation between discretionary loan loss provisioning and stock price illiquidity as measured by BidAsk. Panel A of this table reports the regression results of equation (8), where DLLP is measured by one-period DLLP. Column (1) to (4) in Panel A reports the regression results when $D L L P$ is measured by $D L L P 1, D L L P 2, D L L P 3$, and DLLP4 respectively. Panel B reports the regression results of equation (9), where $D L L P$ is measured by accumulated $D L L P(A D L L P)$. Column (1) to (4) in Panel B reports the regression results when $A D L L P$ is measured by $A D L L P 1, A D L L P 2$, $A D L L P 3$, and $A D L L P 4$ respectively. Appendix B provides all the variable definitions and data sources. Each column reports the coefficient estimates and t-statistics (in parentheses) of each model. All regression models are estimated with both time-fixed and firm-fixed effect model. The sample period is from $2000 \mathrm{Q} 1$ to 2016Q4. ***,**, and * represent $1 \%, 5 \%$, and 10\% significance, respectively. 
Table 2-11 The regression results for the relation between $D L L P$ and $Z E R O$

\begin{tabular}{|c|c|c|c|c|}
\hline \multicolumn{5}{|c|}{ Dependent variable: $Z E R O$} \\
\hline \multicolumn{5}{|c|}{ Panel A: Using DLLP as the independent variable } \\
\hline & (1) & (2) & (3) & (4) \\
\hline$D L L P 1$ & $0.156(0.946)$ & & & \\
\hline$D L L P 2$ & & $-0.493 * *(-2.171)$ & & \\
\hline$D L L P 3$ & & & $-0.184(-1.080)$ & \\
\hline$D L L P 4$ & & & & $-0.485 * *(-2.136)$ \\
\hline ROA & $-1.412 * * *(-9.944)$ & $-1.576 * * *(-12.616)$ & $-1.554 * * *(-11.481)$ & $-1.574 * * *(-12.604)$ \\
\hline SIZE & $-0.016 * * *(-13.644)$ & $-0.016 * * *(-13.071)$ & $-0.016 * * *(-13.651)$ & $-0.016 * * *(-13.066)$ \\
\hline TIER1 & $-0.001 * * *(-8.318)$ & $-0.001 * * *(-8.207)$ & $-0.001 * * *(-8.236)$ & $-0.001 * * *(-8.211)$ \\
\hline$\Delta$ Loan & $-0.016 * * *(-3.215)$ & $-0.017 * * *(-3.288)$ & $-0.017 * * *(-3.263)$ & $-0.017 * * *(-3.288)$ \\
\hline Depo & $0.008 * * *(4.596)$ & $0.008 * * *(4.717)$ & $0.008 * * *(4.618)$ & $0.008 * * *(4.718)$ \\
\hline$M T B$ & $-0.011 * * *(-14.712)$ & $-0.011 * * *(-14.537)$ & $-0.011 * * *(-14.665)$ & $-0.011 * * *(-14.535)$ \\
\hline Turnover & $0.000(1.537)$ & $0.000(1.543)$ & $0.000(1.602)$ & $0.000(1.545)$ \\
\hline$R E T$ & $0.216 *(1.790)$ & $0.223 *(1.842)$ & $0.214 *(1.768)$ & $0.223 *(1.841)$ \\
\hline RET_vol & $-1.263 * * *(-29.389)$ & $-1.246 * * *(-28.719)$ & $-1.259 * * *(-29.284)$ & $-1.246 * * *(-28.722)$ \\
\hline Price & $-0.001 * * *(-14.002)$ & $-0.001 * * *(-13.941)$ & $-0.001 * * *(-14.001)$ & $-0.001 * * *(-13.935)$ \\
\hline$V I X$ & $0.023 * * *(7.274)$ & $0.023 * * *(7.278)$ & $0.023 * * *(7.274)$ & $0.023 * * *(7.279)$ \\
\hline SPRET & $75.561 * * *(4.937)$ & $74.850 * * *(4.907)$ & $75.574 * * *(4.937)$ & $74.861 * * *(4.908)$ \\
\hline No. of obs. & 18899 & 18676 & 18896 & 18674 \\
\hline Adj. R-Squared & 0.168 & 0.166 & 0.168 & 0.166 \\
\hline Time fixed effects & Yes & Yes & Yes & Yes \\
\hline Firm fixed effects & Yes & Yes & Yes & Yes \\
\hline \multicolumn{5}{|c|}{ Panel B: Using ADLLP as the independent variable } \\
\hline & $(1)$ & (2) & (3) & (4) \\
\hline$A D L L P 1$ & $0.508 * * *(9.095)$ & & & \\
\hline$A D L L P 2$ & & $0.301 * * *(3.174)$ & & \\
\hline$A D L L P 3$ & & & $0.363 * * *(5.898)$ & \\
\hline$A D L L P 4$ & & & & $0.302 * * *(3.181)$ \\
\hline$R O A$ & $-1.125 * * *(-9.174)$ & $-1.427 * * *(-12.046)$ & $-1.297 * * *(-10.739)$ & $-1.426 * * *(-12.037)$ \\
\hline SIZE & $-0.013 * * *(-11.145)$ & $-0.013 * * *(-10.564)$ & $-0.013 * * *(-10.943)$ & $-0.013 * * *(-10.584)$ \\
\hline TIER1 & $-0.001 * * *(-7.907)$ & $-0.001 * * *(-7.760)$ & $-0.001 * * *(-8.126)$ & $-0.001 * * *(-7.748)$ \\
\hline$\Delta$ Loan & $-0.016 * * *(-3.086)$ & $-0.017 * * *(-3.367)$ & $-0.017 * * *(-3.445)$ & $-0.017 * * *(-3.337)$ \\
\hline Depo & $0.006 * * *(3.472)$ & $0.007 * * *(4.294)$ & $0.006 * * *(3.792)$ & $0.007 * * *(4.381)$ \\
\hline$M T B$ & $-0.008 * * *(-10.888)$ & $-0.008 * * *(-10.146)$ & $-0.008 * * *(-10.744)$ & $-0.008 * * *(-10.126)$ \\
\hline Turnover & $0.000(-0.869)$ & $0.000(-0.754)$ & $0.000(-0.662)$ & $0.000(-0.766)$ \\
\hline$R E T$ & $0.127(1.081)$ & $0.143(1.209)$ & $0.152(1.291)$ & $0.143(1.205)$ \\
\hline RET_vol & $-1.239 * * *(-28.673)$ & $-1.186 * * *(-26.911)$ & $-1.219 * * *(-28.161)$ & $-1.186 * * *(-26.904)$ \\
\hline Price & $-0.001 * * *(-13.305)$ & $-0.001 * * *(-13.428)$ & $-0.001 * * *(-13.234)$ & $-0.001 * * *(-13.476)$ \\
\hline$V I X$ & $0.021 * * *(7.661)$ & $0.020 * * *(7.550)$ & $0.020 * * *(7.591)$ & $0.020 * * *(7.553)$ \\
\hline SPRET & $-254.469 * * *(-7.053)$ & $-250.849 * * *(-6.970)$ & $-252.630 * * *(-6.991)$ & $-251.017 * * *(-6.975)$ \\
\hline No. of obs. & 17020 & 16690 & 17015 & 16687 \\
\hline Adj. R-Squared & 0.082 & 0.073 & 0.079 & 0.073 \\
\hline Time fixed effects & Yes & Yes & Yes & Yes \\
\hline Firm fixed effects & Yes & Yes & Yes & Yes \\
\hline
\end{tabular}

Notes: This table reports the regression results for the relation between discretionary loan loss provisioning and stock price illiquidity as measured by ZERO. Panel A of this table reports the regression results of equation (8), where DLLP is measured by one-period DLLP. Column (1) to (4) in Panel A reports the regression results when $D L L P$ is measured by $D L L P 1, D L L P 2, D L L P 3$, and $D L L P 4$ respectively. Panel B reports the regression results of equation (9), where $D L L P$ is measured by accumulated $D L L P(A D L L P)$. Column (1) to (4) in Panel B reports the regression results when $A D L L P$ is measured by $A D L L P 1, A D L L P 2$, $A D L L P 3$, and $A D L L P 4$ respectively. Appendix B provides all the variable definitions and data sources. Each column reports the coefficient estimates and t-statistics (in parentheses) of each model. All regression models are estimated with both time-fixed and firm-fixed effect model. The sample period is from $2000 \mathrm{Q} 1$ to 2016Q4. $* * *, * *$, and $*$ represent $1 \%, 5 \%$, and $10 \%$ significance, respectively. 
The results in Table 2-9 to Table $2-11^{13}$ show several findings. First, when using the one-period $D L L P$ as the predictor in testing the relation between $D L L P$ and $S T I$, the results are sensitive to the $D L L P$ measure choice and the $S T I$ measure choice. As shown in Panel A - Table 2-9, DLLP is positively and significantly associated with Amihud when the $D L L P$ is measured by $D L L P 2, D L L P 3$, and $D L L P 4$. All coefficients of these three DLLP measures are significant at $1 \%$ significance level. The coefficient on DLLP1 is positive, but not significant. As reported in Panel A - Table 2-10 and Panel A - Table 2-11, when $S T I$ is measured by BidAsk or ZERO, there is no significant and positive relationship between $D L L P$ and $S T I$. These results suggest that the one-period $D L L P$ is not a reliable predictor of the reduced stock trading liquidity.

Second, we observe very consistent results when using the $A D L L P$ as the predictor in testing the relation between $A D L L P$ and $S T I$. As shown in Panel B - Table 2-9, Panel B - Table 2-10, and Panel B - Table 2-11, the coefficients on all ADLLP measures are positive and significant at $1 \%$ significance level. This finding suggests that banks with a high level of accounting discretion, as measured by $A D L L P$, are associated with a higher level of Amihud, BidAsk, or ZERO. This finding supports our first hypothesis that banks associated with greater opacity are associated with reduced stock trading liquidity. This result holds when we use alternative $A D L L P$ measures generated by different $L L P$ models. Compared

\footnotetext{
${ }^{13}$ For each of the baseline regressions, we perform the Breusch-Pagan Lagrange Multiplier Test to examine residuals' heteroskedasticity problem. The Breusch-Pagan Test result suggests the presence of heteroskedasticity. To address the heteroskedasticity concern, in the unreported additional regressions, we obtain the heteroskedasticity-consistent coefficient estimates via the method proposed by Arellano (1987). The significance of the adjusted coefficients for $D L L P S$ (and $A D L L P S$ ) is not significantly affected. We also perform the Durbin-Watson Test to examine serial correlation in residuals. The Durbin-Watson Test result shows that we cannot reject the null hypothesis that there is no serial correlation in idiosyncratic errors. So we don't have the problem of serial correlation in errors. In addition, to address the concerns for multicollinearity, we calculate the Variance Inflation Factors (VIFs). We find no evidence of the presence of a multicollinearity problem.
} 
to one-period $D L L P, A D L L P$ is a more reliable and powerful predictor of reduced stock trading liquidity.

\subsubsection{The robustness checks}

The baseline results as reported in 2.4.3.2 show that when opacity is measured accumulated $D L L P(A D L L P)$, the opacity is significantly and positively related to all the three $S T I$ measures, and the results are robust to all $A D L L P$ measures generated by different LLP models. Therefore, $A D L L P$ can be used as a more reliable measure than the one-period $D L L P$ in measuring banks' opacity. We conclude that banks' greater opacity as measured by a higher level of $A D L L P$ leads to a higher level of STI. To examine if this conclusion is robust to additional conditions, we perform the following robustness checks to test the relation between $A D L L P$ and $S T I$.

The first robustness check is to add a control variable BIG4 that accounts for banks' financial reporting quality to equation (9). Prior studies suggest that if the auditor is from one of the largest global auditing firms, the informativeness of a firm's accounting data is likely to be better (Lang and Maffett, 2011). So, we use the auditing firm dummy (BIG4) to account for such accounting quality. BIG4 is set to one if a bank's auditing firm is from one of the four largest accounting firms (named as KPMG, Ernst \& Young, PricewaterhouseCoopers, and Deloitte Touche Tohmatsu), and zero otherwise. The reason we did not include BIG4 in equation (9) in the first place is because that Compustat database only provides auditing firm information since the year 2005, and the other variables in our data sample start from 2000. Therefore, including BIG4 in the regression will lead to a reduced sample size. But we are still interested in the results when the auditing 
firm information is controlled. So as a robustness check, we replicate the test by adding $B I G 4_{i, t-1}$ as a control variable to get more robust results. ${ }^{14}$

The second robustness check is to add a control variable $N A S D A Q$ that accounts for banks' stock exchange information to equation (9). Prior studies suggest that stock exchange information accounts for systematic differences in the market microstructure (Ding and Hou, 2015). So as a robustness test, we add an exchange dummy $N A S D A Q_{i}$ and replicate the test by using pooling OLS method. NASDAQ $Q_{i}$ is set to one if bank $i$ is listed on NASDAQ, and zero otherwise. We did not include $N A S D A Q$ at the beginning because we use the individual fixed effect to estimate the baseline regression. Using fixed effect model will drop the time-invariant independent variable $N A S D A Q_{i}$. In this robustness check, we replicate the test by using pooling OLS model (with time-fixed effect). This method allows us to include time-invariant independent variables in the regression model.

The third robustness check is to examine if the results are robust when we exclude the influence from the financial crisis from 2008 to 2009 . This check is to address the concern that the baseline results can be driven by the large market volatility during the crisis period. Following Chang, Chen, and Zolotoy (2017), we exclude observations from 2008Q1 to 2009Q4 and re-estimate equation (9).

The final robustness check is to examine if the results are robust when we use a longer accumulated period to measure $A D L L P$. Instead of calculating $A D L L P$ as the sum of accumulated 4 quarters' $D L L P$ as shown in equation (5), now we calculate $A D L L P$ as

\footnotetext{
${ }^{14}$ Because banks may change their auditing firms, $B I G 4$ is not a time-invariant variable. $B I G 4_{i, t-1}$ is defined as bank $i$ 's auditing firm dummy at quarter $t-1$. In addition, we only consider the 'BIG 4' auditing firm but not the 'BIG 5' auditing firm because Compustat provides available information starting from 2005, when the auditing firm Arthur Andersen was dropped from the top auditing firm list after the Enron scandal.
} 
the sum of accumulated 8 quarters' $D L L P$ as shown in equation (14). We replicate the test by using this 8-quarter accumulated $A D L L P$.

$$
\begin{aligned}
& A D L L P_{i, t-1}=D L L P_{i, t-1}+D L L P_{i, t-2}+D L L P_{i, t-3}+D L L P_{i, t-4}+D L L P_{i, t-5}+ \\
& D L L P_{i, t-6}+D L L P_{i, t-7}+D L L P_{i, t-8} .
\end{aligned}
$$

Table 2-12 reports the robustness check results for the relation between ADLLP and STI using equation (9). In Column (1), the regression dependent variable is Amihud. In Column (2), the regression dependent variable is BidAsk. In Column (3), the regression dependent variable is $Z E R O$. Each row reports the regression results when using different ADLLP measures. We report the coefficient estimates and t-statistics (in parentheses) of $A D L L P$ only, which is the key explanatory variable of interest. The other variables' coefficient estimates and t-statistics are not tabulated to save space. From the first to the last row in each panel, the $A D L L P$ in the regression is measured by $A D L L P 1, A D L L P 2$, $A D L L P 3$, and $A D L L P 4$, separately. Panel A in Table 2-12 reports the results when adding an additional explanatory dummy variable $B I G 4$ to equation (9). Panel B reports the results when adding an additional explanatory dummy variable $N A S D A Q$ to equation (9). Panel $\mathrm{C}$ reports the results of estimating equation (9) excluding observations during the past financial crisis from 2008Q1 to 2009Q4. Panel D reports the results of estimating equation (9) using alternative $A D L L P$ measures. 
Table 2-12 ADLLP and STI: additional analysis

\begin{tabular}{cccc}
\hline \multicolumn{4}{c}{ Coefficients of $A D L L P$} \\
Panel A: Including BIG4 as an explanatory variable \\
Amihud & $(2)$ & (3) \\
ADLLP1 & $13.399 * * *(4.555)$ & BidAsk & ZERO \\
ADLLP2 & $20.630 * * *(4.042)$ & $0.086^{* * *}(5.532)$ & $0.528^{* * *}(8.968)$ \\
ADLLP3 & $17.050 * * *(5.125)$ & $0.070 * * *(2.578)$ & $0.395 * * *(3.810)$ \\
ADLLP4 & $20.480 * * *(4.010)$ & $0.076 * * *(4.301)$ & $0.470 * * *(7.042)$ \\
\end{tabular}

\begin{tabular}{|c|c|c|c|}
\hline & Amihud & BidAsk & ZERO \\
\hline$A D L L P 1$ & $9.920 * * *(3.140)$ & $0.050 * * *(2.857)$ & $0.558 * * *(10.180)$ \\
\hline$A D L L P 2$ & $40.910 * * *(8.058)$ & $0.160 * * *(5.687)$ & $0.667 * * *(7.508)$ \\
\hline$A D L L P 3$ & $18.890 * * *(5.674)$ & $0.054 * * *(2.948)$ & $0.532 * * *(9.204)$ \\
\hline$A D L L P 4$ & $40.903 * * *(8.041)$ & $0.161 * * *(5.716)$ & $0.665 * * *(7.469)$ \\
\hline \multicolumn{4}{|c|}{ Panel C: Excluding observations during financial crisis (2008Q1-2009Q3) } \\
\hline & Amihud & BidAsk & ZERO \\
\hline$A D L L P 1$ & $7.612 * * *(2.819)$ & $0.048 * * *(3.715)$ & $0.516 * * *(7.223)$ \\
\hline$A D L L P 2$ & $15.498 * * *(3.443)$ & $0.067 * * *(3.097)$ & $0.369 * * *(3.094)$ \\
\hline$A D L L P 3$ & $10.968 * * *(3.778)$ & $0.038 * * *(2.702)$ & $0.288 * * *(3.745)$ \\
\hline$A D L L P 4$ & $15.550 * * *(3.445)$ & $0.069 * * *(3.154)$ & $0.369 * * *(3.089)$ \\
\hline \multicolumn{4}{|c|}{ Panel D: Using sum of the past 8-quarter DLLP as the ADLLP } \\
\hline & Amihud & BidAsk & ZERO \\
\hline$A D L L P 1$ & $9.452 * * *(5.909)$ & $0.058 * * *(6.779)$ & $0.379 * * *(11.107)$ \\
\hline$A D L L P 2$ & $25.968 * * *(8.915)$ & $0.098 * * *(6.283)$ & $0.466 * * *(7.327)$ \\
\hline$A D L L P 3$ & $14.050 * * *(7.650)$ & $0.067 * * *(6.837)$ & $0.358 * * *(9.093)$ \\
\hline$A D L L P 4$ & $25.895 * * *(8.877)$ & $0.098 * * *(6.256)$ & $0.465 * * *(7.307)$ \\
\hline
\end{tabular}

Notes: This table reports the additional analysis results for the relation between ADLLP and STI using equation (9). In Column (1), the regression dependent variable is Amihud. In Column (2), the regression dependent variable is BidAsk. In Column (3), the regression dependent variable is ZERO. Each row reports the regression results when using different $A D L L P$ measures. We only report the coefficient estimates and tstatistics (in parentheses) of $A D L L P$ only, which is the key explanatory variable of interest. The other variables' coefficient estimates and t-statistics are not tabulated to save space. From the first to the last row in each panel, the $A D L L P$ in the regression is measured by $A D L L P 1, A D L L P 2, A D L L P 3$, and ADLLP4, separately.

Panel A reports the results when adding an additional explanatory variable $B I G 4$ to equation (9). We estimate equation (9) for Panel A using the firm-fixed and time-fixed effect model. Panel B reports the results when adding an additional explanatory variable $N A S D A Q$ to equation (9). We estimate equation (9) for Panel B using the time-fixed effect model. Panel $\mathrm{C}$ reports the results of estimating equation (9) excluding observations during the past financial crisis from 2008Q1 to 2009Q4 (the results are robust when excluding the crisis period from 2007Q1 to 2009Q4). We estimate equation (9) for Panel C using the firm-fixed and time-fixed effect model. Panel D reports the results of estimating equation (9) using alternative $A D L L P$ measures: the accumulated $D L L P(A D L L P)$ is calculated as the sum of past 8-quarter $D L L P$ (instead of past4 quarter $\quad D L L P): \quad A D L L P_{i, t-1}=D L L P_{i, t-1}+D L L P_{i, t-2}+D L L P_{i, t-3}+D L L P_{i, t-4}+D L L P_{i, t-5}+$ $D L L P_{i, t-6}+D L L P_{i, t-7}+D L L P_{i, t-8}$. We estimate equation (9) for Panel D using the firm-fixed and timefixed effect model.

The sample period is from 2000Q1 to 2016Q4 (expect for Panel C). Appendix B provides all the variable definitions and data sources. $* * *, * *$, and $*$ represent $1 \%, 5 \%$, and $10 \%$ significance, respectively. 
All the results in Table 2-12 show that the relation between ADLLP and STI is positive and significant in all these additional checks. The coefficients on all ADLLPS are significant at $1 \%$ level. So, we can say that the ADLLPs generated by all four LLP models are reliable predictors of STI. The conclusion is robust after controlling for the auditing firm information, the exchange information, using different regression method, excluding the financial crisis influence, or using a longer accumulating period to measure $A D L L P$.

\subsubsection{Empirical results for the relation between $D L L P$ ' and $S P C R$}

\subsubsection{The summary statistics and correlation matrix of the main variables}

Table 2-13 reports the summary statistics of the variables to be used in the regression tests on the relation between $D L L P$ ' and SPCR. The sample period is from 2000 to 2016. Column 1 reports the number of bank-year observations (after excluding missing values). Column 2 and Column 3 report the mean and standard deviations, respectively. Column $4-6$ report the quantiles as $25 \%, 50 \%$ (median), and 75\%, respectively.

Table 2-14 reports the correlation coefficients of all the DLLP' measures and $N S K E W$. We see that the DLLP' measures and the NSKEW measure are positively correlated with each other, consistent with the notion that firms with higher opacity are associated with greater stock price crash risk. 
Table 2-13 Descriptive statistics based on bank-year observations between 2000 to 2016

\begin{tabular}{lcccccc}
\hline & $\mathrm{N}$ & Mean & Std.Dev & $25 \%$ quantile & Median & $75 \%$ quantile \\
\hline NSKEW & 7867 & -0.112 & 0.591 & -0.451 & -0.102 & 0.235 \\
DLLP1' & 5245 & 0.006 & 0.006 & 0.003 & 0.004 & 0.007 \\
DLLP2' & 5106 & 0.003 & 0.004 & 0.001 & 0.002 & 0.004 \\
DLLP3' & 5243 & 0.005 & 0.006 & 0.002 & 0.003 & 0.006 \\
DLLP4' & 5105 & 0.003 & 0.004 & 0.001 & 0.002 & 0.004 \\
ROA & 7864 & 0.006 & 0.010 & 0.005 & 0.008 & 0.011 \\
SIZE & 7865 & 7.509 & 1.475 & 6.459 & 7.175 & 8.237 \\
TIER1 & 7636 & 12.109 & 3.365 & 9.900 & 11.600 & 13.750 \\
ALoan & 6916 & 0.101 & 0.165 & 0.007 & 0.074 & 0.158 \\
Depo & 7862 & 1.191 & 0.306 & 1.015 & 1.130 & 1.297 \\
MTB & 7856 & 1.440 & 0.701 & 0.951 & 1.322 & 1.819 \\
Turnover & 7865 & 2.529 & 2.882 & 0.791 & 1.518 & 3.039 \\
RET & 7867 & 0.000 & 0.001 & 0.000 & 0.001 & 0.001 \\
RET_vol & 7867 & 0.022 & 0.010 & 0.015 & 0.019 & 0.026 \\
Price & 7867 & 19.820 & 13.010 & 10.950 & 16.889 & 25.774 \\
BidAsk & 7861 & 0.016 & 0.019 & 0.003 & 0.010 & 0.022 \\
VIX & 14824 & 20.388 & 6.165 & 15.480 & 17.799 & 24.203 \\
SPRET & 14824 & 0.000 & 0.001 & 0.000 & 0.000 & 0.001 \\
\hline NOtes: This & & &
\end{tabular}

Notes: This table reports the descriptive statistics based on all bank-year observations for testing the relation between DLLP' and SPCR. Column 1 report the number of observations (excluding missing values). Column 2 and Column 3 report the mean and standard deviations, respectively. Column $4-6$ report the quantiles as $25 \%, 50 \%$ (median), and 75\%, respectively. The sample period is from 2000 to 2016 . All variables are calculated as defined in Appendix B.

Table 2-14 Correlation matrix for testing the relation between $D L L P($ and $A D L L P)$ and $S P C R$.

\begin{tabular}{lccccc}
\hline & $N S K E W$ & $D L L P 1^{\prime}$ & $D L L P 2^{\prime}$ & $D L L P 3^{\prime}$ & $D L L P 4^{\prime}$ \\
\hline NSKEW & 1.000 & 0.085 & 0.050 & 0.066 & 0.050 \\
$D L L P 1^{\prime}$ & 0.085 & 1.000 & 0.708 & 0.877 & 0.709 \\
$D L L P 2^{\prime}$ & 0.050 & 0.708 & 1.000 & 0.768 & 1.000 \\
$D L L P 3^{\prime}$ & 0.066 & 0.877 & 0.768 & 1.000 & 0.762 \\
$D L L P 4^{\prime}$ & 0.050 & 0.709 & 1.000 & 0.762 & 1.000 \\
\hline
\end{tabular}

Notes: This table reports the correlation matrix of the major variables of interest for testing the relation between $D L L P^{\prime}$ and $S P C R$. All variables are calculated as defined in Appendix B.

\subsubsection{The baseline results}

In this section, we report the baseline regression results of equation (12), which models the relation between $D L L P^{\prime}$ and $S P C R$ as measured by NSKEW.

Table 2-15 reports the regression results. Column (1) to (4) reports the regression results when DLLP' is measured by $D L L P 1^{\prime}, D L L P 2^{\prime}, D L L P 3^{\prime}$, and $D L L P 4^{\prime}$ ' respectively. 
All regression models are estimated with both time and firm-fixed effect model. The sample period is from 2000 to 2016 .

Table 2-15 The regression results for the relation between DLLP' and SPCR

Dependent variable: NSKEW

\author{
(1)
}

$D L L P 1^{\prime}$

DLLP2'

DLLP3'

DLLP4'

$R O A$

SIZE

TIER 1

$\triangle$ Loan

Depo

MTB

Turnover

$R E T$

RET_vol

Price

BidAsk

$V I X$

SPRET

No. of obs.

R-Squared

Time fixed effects

Firm fixed effects
(2)

$6.067 *(1.753)$

$2.391 *(1.678)$
$0.093 * *(2.142)$
$0.008 *(1.722)$
$0.131 * *(2.016)$
$0.108 *(1.767)$
$0.005(0.197)$
$-0.002(-0.269)$
$-112.502 * * *(-13.916)$
$-8.051 * * *(-3.312)$
$0.006 * * *(3.306)$
$3.031 * *(2.249)$

$-0.039 * *(-2.276)$

$-586.147 * * *(-3.803)$

4751

0.099

Yes
(3)

$$
5.018 * *(2.168)
$$

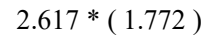

\section{1}

0.099
(4)

Notes: This table reports the regression results for equation (12), which models the relation between $D L L P$, and $S P C R$ as measured by NSKEW. Column (1) to (4) reports the regression results when DLLP' is measured by $D L L P 1$ ', $D L L P 2$ ', $D L L P 3$ ', and $D L L P 4$ ' respectively. Appendix B provides all the variable definitions and data sources. Each column reports the coefficient estimates and t-statistics (in parentheses). All regression models are estimated with both time-fixed and firm-fixed effect model. The sample period is from 2000 to 2016.

***, ${ }^{* *}$, and $*$ represent $1 \%, 5 \%$, and $10 \%$ significance, respectively. 
The results in Table $2-15^{15}$ shows that the coefficients on the four DLLP' measures are all positively and show significance. The coefficient on $D L L P 1$ ' is significant at $1 \%$ significance level. The coefficient on $D L L P 3$ ' is significant at $5 \%$ significance level. The coefficients on $D L L P 2$ ' and $D L L P 4$ ' are significant at $10 \%$ significance level. In general, the results suggest that banks with higher $D L L P^{\prime}$ are associated with more negatively skewed firm-specific returns, which signal greater stock price crash risk. This result supports our second hypothesis that banks with a higher level of opacity, as measured by $D L L P^{\prime}$, are associated with a higher level of stock price crash risk.

\subsubsection{The robustness checks}

In this section, we perform similar robustness checks as we did in Section 2.4.3.3. The purpose is to examine if the positive relationship between $D L L P^{\prime}$ and $S P C R$ still holds when we add additional conditions.

First, we add the auditing firm dummy $(B I G 4)$ to the regression and re-estimate the model. Second, we add an exchange dummy $N A S D A Q_{i}$ and re-estimate the model using pooling OLS method. Third, we exclude observations from 2008 to 2009 and re-estimate equation. Forth, instead of measuring $D L L P^{\prime}{ }_{i, t-1}$ using the sum of quarterly $D L L P$ in year

\footnotetext{
${ }^{15}$ For each of the baseline regressions, we perform the Breusch-Pagan Lagrange Multiplier Test to examine the residuals' heteroskedasticity problem. The Breusch-Pagan Test result suggests no presence of heteroskedasticity. We also perform the Durbin-Watson Test to examine serial correlation in the residuals. The Durbin-Watson Test result suggests no presence of serial correlation in idiosyncratic errors. In addition, to address multicollinearity, we calculate the VIFs. We find no evidence of the presence of a multicollinearity problem.
} 
$t-1$, we use an alternative measure $D L L P^{\prime}{ }_{i, t-1}$, which is defined as the sum of the quarters' $D L L P$ from year $t-2$ to year $t-1$ :

$$
\begin{aligned}
& D L L P_{i, t-1}^{\prime}=D L L P_{i, t-1, Q 1}+D L L P_{i, t-1, Q 2}+D L L P_{i, t-1, Q 3}+D L L P_{i, t-1, Q 4}+ \\
& D L L P_{i, t-2, Q 1}+D L L P_{i, t-2, Q 2}+D L L P_{i, t-2, Q 3}+D L L P_{i, t-2, Q 4} .
\end{aligned}
$$

Table 2-16 reports the additional analysis results for the relation between $D L L P$, and SPCR as measured by NSKEW using equation (12). Each row reports the coefficient estimates and t-statistics (in parentheses) of $D L L P^{\prime}$ measures only. The other variables' coefficient estimates and t-statistics are not tabulated to save space. From the first to the last row in each panel, the $D L L P^{\prime}$ in the regression is measured by $D L L P 1$ ', $D L L P 2^{\prime}$, DLLP3', and DLLP4', separately. 
Table 2-16 DLLP' and $S P C R$ : additional analysis

\begin{tabular}{|c|c|}
\hline Depender & Coefficients of $D L L P^{\prime}$ \\
\hline \multicolumn{2}{|c|}{ Panel A: Including BIG4 as an explanatory variable } \\
\hline$D L L P 1^{\prime}$ & $5.744 * *(2.436)$ \\
\hline$D L L P 2^{\prime}$ & $4.851(1.272)$ \\
\hline$D L L P 3^{\prime}$ & $4.456 *(1.755)$ \\
\hline$D L L P 4^{\prime}$ & $4.664(1.220)$ \\
\hline \multicolumn{2}{|c|}{ Panel B: Adding NASDAQ dummy (using only time-fixed effect model) } \\
\hline$D L L P 1^{\prime}$ & $5.327 * * *(2.757)$ \\
\hline$D L L P 2^{\prime}$ & $4.945 *(1.684)$ \\
\hline$D L L P 3^{\prime}$ & $3.382 *(1.727)$ \\
\hline$D L L P 4^{\prime}$ & $4.907 *(1.667)$ \\
\hline \multicolumn{2}{|c|}{ Panel C: Excluding observations during financial crisis (2008-2009) } \\
\hline$D L L P 1^{\prime}$ & $4.958 *(1.951)$ \\
\hline$D L L P 2^{\prime}$ & $6.523 *(1.676)$ \\
\hline$D L L P 3^{\prime}$ & $4.379 *(1.695)$ \\
\hline$D L L P 4^{\prime}$ & $6.338(1.624)$ \\
\hline \multicolumn{2}{|c|}{ Panel D: Using sum of two years (8 quarter) 'DLLP as the DLLP' } \\
\hline$D L L P 1^{\prime}$ & $0.020(0.014)$ \\
\hline$D L L P 2^{\prime}$ & $0.381(0.157)$ \\
\hline$D L L P 3^{\prime}$ & $0.540(0.352)$ \\
\hline$D L L P 4^{\prime}$ & $0.178(0.073)$ \\
\hline
\end{tabular}

Notes: This table reports the additional analysis results for the relation between $D L L P^{\prime}$ and $S P C R$ as measured by $N S K E W$ using equation (12). Each row reports the coefficient estimates and t-statistics (in parentheses) of $D L L P$ ' only, which is the key explanatory variable of interest. The other variables' coefficient estimates and t-statistics are not tabulated to save space. From the first to the last row in each panel, the $D L L P$ ' in the regression is measured by DLLP1', DLLP2', DLLP3', and DLLP4', separately.

Panel A reports the results when adding an additional explanatory variable $B I G 4$ to equation (12). We estimate equation (12) for Panel A using the firm-fixed and time-fixed effect model. Panel B reports the results when adding an additional explanatory variable $N A S D A Q$ to equation (12). We estimate equation (12) for Panel B using the time-fixed effect model. Panel C reports the results of estimating equation (12) excluding observations during the past financial crisis from 2008 to 2009 (the results are robust when excluding the crisis period from 2007 to 2009). We estimate equation (12) for Panel $\mathrm{C}$ using the firm-fixed and time-fixed effect model. Panel D reports the results of estimating equation (12) using alternative $D L L P$ ' measures. Instead of using only the sum of 4 quarters' $D L L P$, the alternative $D L L P^{\prime}{ }_{i, t-1}$ is defined as the sum of the 8 quarters' $D L L P$ from year t-2 to year t-1 using equation (15). We estimate equation (12) for Panel D using the firm-fixed and time-fixed effect model.

The sample period is from 2000 to 2016 (except for Panel C). Appendix B provides all the variable definitions and data sources. $* * *, * *$, and $*$ represent $1 \%, 5 \%$, and $10 \%$ significance, respectively.

Panel A reports the results when adding an additional explanatory dummy variable $B I G 4$ to equation (12). After controlling for the auditing firm information, the coefficients on the four $D L L P^{\prime}$ measures are still positive, but only the coefficients on $D L L P 1$ ' and 
DLLP3' show significance. The coefficient on $D L L P 1$ ' is significant at $5 \%$ significance level.

Panel B reports the results when adding an additional explanatory dummy variable $N A S D A Q$ to equation (12). After controlling for the exchange listing information, the coefficients on the four $D L L P^{\prime}$ measures are still positive and significant. In particular, the coefficient on $D L L P 1$ ' is significant with $1 \%$ significance level.

Panel $\mathrm{C}$ reports the results of estimating equation (12) excluding observations during the past financial crisis from 2008 to 2009. Coefficients on DLLP1', DLLP2', and $D L L P 3$ ' are positive and significant at $10 \%$ significance after excluding the observations during the crisis period. We also examine if the crisis period is defined as 2007 to 2009 . The main result (not tabulated) also holds. One possible explanation for the reduced significance in the coefficients of $D L L P^{\prime}$ during non-crisis period is that, in the crisis period, stock price crash risk is more sensitive to the $D L L P^{\prime}$, whereas during the non-crisis period, the sensitivity is weaker. This finding is consistent with the findings from Cohen, Cornett, Marcus, and Tehranian (2014). They find that banks' earnings management has little impact on $S P C R$ during the market quiet periods. But banks with more aggressive earnings management prior to the crisis period are more likely to meet large stock price crashes during the crisis years.

Panel D reports the results of estimating equation (12) using $D L L P^{\prime}$ measures when $D L L P^{\prime}$ is defined as the sum of the 8 quarters' $D L L P$. Surprisingly, all the four $D L L P^{\prime}$ measures lost their significance. This result suggests that the $D L L P^{\prime}$ ' measure as computed with the sum of four quarters' $D L L P$ would be a more powerful indicator for bank opacity than the $D L L P^{\prime}$ measured by the sum of eight quarters' $D L L P$. 
In summary, according to the baseline regression results and robustness check results, we find that among the four $D L L P^{\prime}$ measures, the $D L L P 1$ ' generated from LLP model (1) can better capture the correlation with the stock price crash risk than the other three $D L L P^{\prime}$ measures. As we mentioned in Section 2.2.1, Beatty and Liao (2014) find that the DLLP generated from LLP model (1) can better capture banks' provisioning practice. Our findings also suggest that the LLP model (1) can generate a better opacity measure.

\subsection{Conclusions}

Existing theories suggest that firm opacity will lead to reduced stock trading liquidity and increased stock price crash risk. In this study, we empirically confirm this relationship using data from the banking sector.

We construct two sets of $D L L P$ measures: the one-period $D L L P$, and the accumulated $D L L P(A D L L P)$. Different $D L L P$ measures are generated by different LLP models as introduced in Beatty and Liao (2014).

We first find that our measure of opacity, the accumulated $D L L P(A D L L P)$, is a reliable predictor of $S T I$, where $S T I$ can be measured by Amihud's illiquidity measure, BidAsk spread, or zero-return day ratio. The findings confirm the hypothesis that banks with greater opacity are associated with reduced stock trading liquidity. The results are robust when controlling for the auditing firm information or the exchange information. The results are also robust when using alternative $A D L L P$ measures. On the other hand, we do not find that one-period $D L L P$ can be used as a reliable predictor of reduced stock trading liquidity. This result suggests that banks' opacity is reflected in the accumulated discretionary loan 
loss provisioning practice rather than the one-period discretionary loan loss provisioning practice.

Second, we find that the accumulated $D L L P\left(D L L P 1^{\prime}\right)$ generated from the preferred LLP model from Beatty and Liao (2014), is a reliable predictor of SPCR, which is measured by the negative skewness of firm-specific weekly returns. This result suggests that banks associated with greater opacity, which is measured by DLLP1', are more likely to experience stock price crash risk. The association is stronger during the 2008-2009 financial crisis period.

Overall, the findings suggest, banks' discretionary provisioning practice, using our proxy for it, is related to the firms' opacity feature as manifested in their stock trading information. The findings from this study may provide future studies in this area a reference in choosing an appropriate $D L L P$ measure to capture banks' financial reporting opacity.

\section{References}

Acharya, V. V., \& Pedersen, L. H. (2005). Asset pricing with liquidity risk. Journal of financial Economics, 77(2), 375-410.

Amihud, Y. (2002). Illiquidity and stock returns: cross-Section and time-series effects. Journal of financial markets, 5(1), 31-56.

Amihud, Y., \& Mendelson, H. (1986). Asset pricing and the bid-ask spread. Journal of financial Economics, 17(2), 223-249.

Arellano, M. (1987). PRACTITIONERS'CORNER: Computing Robust Standard Errors for Within-groups Estimators. Oxford bulletin of Economics and Statistics, 49(4), 431-434.

Balla, E., Rose, M. J., \& Romero, J. S. (2012). Loan loss reserve accounting and bank behavior. Richmond Fed Economic Brief, (Mar).

Beatty, A., \& Liao, S. (2011). Do delays in expected loss recognition affect banks' willingness to lend? Journal of accounting and economics, 52(1), 1-20.

Beatty, A., \& Liao, S. (2014). Financial accounting in the banking industry: A review of the empirical literature. Journal of Accounting and Economics, 58(2-3), 339-383. 
Beatty, A., Chamberlain, S. L., \& Magliolo, J. (1995). Managing financial reports of commercial banks: The influence of taxes, regulatory capital, and earnings. Journal of accounting research, 231-261.

Beaver, W. H., \& Engel, E. E. (1996). Discretionary behavior with respect to allowances for loan losses and the behavior of security prices. Journal of Accounting and Economics, 22(1-3), 177-206.

Beck, P. J., \& Narayanamoorthy, G. S. (2013). Did the SEC impact banks' loan loss reserve policies and their informativeness?. Journal of Accounting and Economics, 56(2-3), 42-65.

Beyer, A., Cohen, D. A., Lys, T. Z., \& Walther, B. R. (2010). The financial reporting environment: Review of the recent literature. Journal of accounting and economics, 50(2), 296-343.

Brunnermeier, M. K., \& Pedersen, L. H. (2008). Market liquidity and funding liquidity. The Review of Financial Studies, 22(6), 2201-2238.

Bushman, R. M. (2016). Transparency, accounting discretion, and bank stability. Economic Policy Review, (Aug), 129-149.

Bushman, R. M., \& Williams, C. D. (2012). Accounting discretion, loan loss provisioning, and discipline of banks' risk-taking. Journal of Accounting and Economics, 54(1), 1-18.

Bushman, R. M., \& Williams, C. D. (2015). Delayed expected loss recognition and the risk profile of banks. Journal of Accounting Research, 53(3), 511-553.

Chang, X., Chen, Y., \& Zolotoy, L. (2017). Stock liquidity and stock price crash risk. Journal of financial and quantitative analysis, 52(4), 1605-1637.

Chen, J., Hong, H., \& Stein, J. C. (2001). Forecasting crashes: Trading volume, past returns, and conditional skewness in stock prices. Journal of financial Economics, 61(3), 345-381.

Chung, K. H., \& Zhang, H. (2014). A simple approximation of intraday spreads using daily data. Journal of Financial Markets, 17, 94-120.

Cohen, L. J., Cornett, M. M., Marcus, A. J., \& Tehranian, H. (2014). Bank earnings management and tail risk during the financial crisis. Journal of Money, Credit and Banking, 46(1), 171-197.

Collins, J. H., Shackelford, D. A., \& Wahlen, J. M. (1995). Bank differences in the coordination of regulatory capital, earnings, and taxes. Journal of accounting research, 263-291.

Dahiya, S., Iannotta, G., \& Navone, M. (2017). Firm opacity lies in the eye of the beholder. Financial Management, 46(3), 553-592.

Ding, R., \& Hou, W. (2015). Retail investor attention and stock liquidity. Journal of International Financial Markets, Institutions and Money, 37, 12-26.

Easley, D., \& O'hara, M. (2004). Information and the cost of capital. The journal of finance, 59(4), 15531583.

Greene, W. H. (2003). Econometric analysis. Pearson Education India.

Grossman, S. J., \& Stiglitz, J. E. (1980). On the impossibility of informationally efficient markets. The American economic review, 70(3), 393-408.

Healy, P. M., Hutton, A. P., \& Palepu, K. G. (1999). Stock performance and intermediation changes surrounding sustained increases in disclosure. Contemporary accounting research, 16(3), 485-520. 
Healy, P. M., Hutton, A. P., \& Palepu, K. G. (1999). Stock performance and intermediation changes surrounding sustained increases in disclosure. Contemporary accounting research, 16(3), 485-520.

Ho, T., \& Stoll, H. R. (1980). On dealer markets under competition. The Journal of Finance, 35(2), 259-267.

Hong, H. A., KIM, J. B., \& Welker, M. (2017). Divergence of cash flow and voting rights, opacity, and stock price crash risk: international evidence. Journal of Accounting Research, 55(5), 1167-1212.

Hong, H., \& Stein, J. C. (1999). A unified theory of underreaction, momentum trading, and overreaction in asset markets. The Journal of finance, 54(6), 2143-2184.

Huizinga, H., \& Laeven, L. (2012). Bank valuation and accounting discretion during a financial crisis. Journal of Financial Economics, 106(3), 614-634.

Hung, S., \& Qiao, Z. (2017). Shadows in the Sun: Crash risk behind Earnings Transparency. Journal of Banking \& Finance, 83, 1-18.

Hutton, A. P., Marcus, A. J., \& Tehranian, H. (2009). Opaque financial reports, R2, and crash risk. Journal of financial Economics, 94(1), 67-86.

Jiang, L., Levine, R., \& Lin, C. (2016). Competition and bank opacity. The Review of Financial Studies, 29(7), 1911-1942.

Jin, J. Y., Kanagaretnam, K., \& Liu, Y. (2018). Banks' funding structure and earnings quality. International Review of Financial Analysis, 59, 163-178.

Jin, L., \& Myers, S. C. (2006). R2 around the world: New theory and new tests. Journal of financial Economics, 79(2), 257-292.

Kanagaretnam, K., Krishnan, G. V., \& Lobo, G. J. (2010). An empirical analysis of auditor independence in the banking industry. The Accounting Review, 85(6), 2011-2046.

Kim, J. B., Li, Y., \& Zhang, L. (2011). Corporate tax avoidance and stock price crash risk: Firm-level analysis. Journal of Financial Economics, 100(3), 639-662.

Kim, M. S., \& Kross, W. (1998). The impact of the 1989 change in bank capital standards on loan loss provisions and loan write-offs. Journal of Accounting and Economics, 25(1), 69-99.

Kyle, A. S. (1985). Continuous auctions and insider trading. Econometrica: Journal of the Econometric Society, 1315-1335.

Lang, M., Lins, K. V., \& Maffett, M. (2012). Transparency, liquidity, and valuation: International evidence on when transparency matters most. Journal of Accounting Research, 50(3), 729-774.

Lesmond, D. A., Ogden, J. P., \& Trzcinka, C. A. (1999). A new estimate of transaction costs. The Review of Financial Studies, 12(5), 1113-1141.

Leuz, C., \& Verrecchia, R. (2000). The economic consequences of increased disclosure. Journal of Accounting Research, 38, 91-124.

Liu, C. C., \& Ryan, S. G. (2006). Income smoothing over the business cycle: Changes in banks' coordinated management of provisions for loan losses and loan charge-offs from the pre-1990 bust to the 1990s boom. The Accounting Review, 81(2), 421-441. 
McNichols, M. F. (2002). Discussion of the quality of accruals and earnings: The role of accrual estimation errors. The accounting review, 77(s-1), 61-69.

Tran, V. D., Hassan, M. K., \& Houston, R. (2018). Discretionary Loan-Loss Provision Behavior in the US Banking Industry (No. 2018-WP-01). Indiana State University, Scott College of Business, Networks Financial Institute.

Vyas, D. (2011). The Timeliness of Accounting Write-Downs by US Financial Institutions During the Financial Crisis of 2007-2008. Journal of accounting research, 49(3), 823-860.

Wahlen, J. M. (1994). The nature of information in commercial bank loan loss disclosures. Accounting Review, 455-478.

Welker, M. (1995). Disclosure policy, information asymmetry, and liquidity in equity markets. Contemporary accounting research, 11(2), 801-827. 


\section{Chapter 3: Depositors' Discipline, Banks' Accounting Discretion, and Depositors' Expectations of Implicit Government Guarantees}

\subsection{Introduction}

After the 2007-2009 financial crisis, policymakers took actions to reduce the likelihood that governments would have to bear the cost of saving distressed banks. For example, the Basel Committee (2015) called for improved disclosure of bank risk under Basel III's Pillar 3. The expected result was that improved risk disclosure would enhance creditors' ability and inclination to monitor banks. The Dodd-Frank Act in the U.S. and the bail-in reforms in the European Union and Canada sought to remove the perception that governments implicitly guarantee banks in order to incent creditors to monitor banks more effectively. Both examples amount to efforts to enhance market discipline in the banking sector.

Market discipline is effective when market participants accurately assess the riskiness of firms and behave accordingly in how they engage with them. For example, when market discipline is effective, financiers typically require a larger risk premium as firms become riskier. Additionally, there is a tendency for financiers to reduce the quantity of funds supplied to firms as they become riskier. The idea of market discipline is that it will cause firms to act responsibly toward how they assume risk because they do not want to face these kinds of punishments in financial markets. Acting responsibly involves matters such as assuming risk when the reward for doing so is sufficient and maintaining risk levels within bounds that are reasonable for all stakeholders in the firm, including those holding financial instruments issued by the firm. 
This paper examines the operation of market discipline in the banking sector, so our focus is on the interest rates depositors demand on uninsured deposits and the quantity of uninsured deposits they supply to banks depending on the level of risk in banks.

There are potentially many ways for banks to assume additional risk. One way involves the adoption of discretionary accounting practices. We use the term discretionary accounting practices to denote the application of management discretion to determine how entries are made in a firm's financial accounts rather than determining those entries using transactions or appropriately supported estimates. Because these practices can be arbitrary and self-serving for management, they tend to obscure fair presentation of financial results or financial position. We surmise that banks that adopt discretionary accounting practices appear riskier to financiers because they lead to information asymmetry between bank managers and financiers. This study examines whether depositors exert market discipline over banks that adopt discretionary accounting practices by demanding larger risk premiums or by reducing the supply of funds.

The discretionary accounting practice we focus on is the use of a discretionary loan loss provision ("DLLP"). We use the term $D L L P$ to denote the difference between an observed provision and a model-determined, notionally correct provision. DLLP is discretionary in the sense that managers adopt them at their discretion rather than because they are supported by appropriately conducted estimations.

The $D L L P$ measure has been used increasingly in recent bank opacity studies (e.g., Bushman and Williams, 2012, 2015; Iannotta and Kwan, 2014; Bushman, Hendricks, and Williams, 2016; Jiang and Levine, 2016; Gallemore, 2016; Costello, Granja, and Weber, 
2016; Dou, Ryan, and Zou, 2017). Here, the term bank opacity refers to the extent to which a bank obscures its true financial condition.

These studies assert that loan loss provisioning is the most important accounting mechanism banks can use to manipulate their financial statement indicators. When a bank chooses loan loss provisions that differ from those that could be considered notionally correct, information uncertainty increases. Also, ongoing deviation of loan loss provisions from those that could be considered notionally correct can result in an accumulation of concealed negative information. This can lead to a price crash in equity markets if all the concealed negative information becomes known to equity market participants at once. This in turn increases the bank's insolvency risk if its ability to raise financing in capital markets is compromised by the price crash. The foregoing raises the possibility that depositors will respond to elevated levels of $D L L P$ by demanding higher interest rates or by withdrawing deposits.

Another focus of this study is to address the widespread concern that implicit government guarantees remove the incentive for financiers to exert market discipline. We examine whether there is empirical support for this idea by examining whether the empirical evidence of market discipline is different for the so-called to-big-to-fail ("TBTF") banks than for other banks. TBTF banks are banks that are so important to the functioning of a country's financial system that they cannot be allowed to fail, usually because failure would lead to material negative spillover effects to the real economy. The supposition for these banks is that if they experience financial distress, the government will step in to rescue them. Consequently, TBTF banks are perceived to be safer than other banks. 
Depositors' incentives to monitor and discipline banks may weaken if depositors believe implicit government guarantees exist, as is potentially the case for TBTF banks. In such a context, depositors may not respond to elevated levels of DLLP by demanding higher interest rates or withdrawing deposits. Prior empirical evidence shows that TBTF banks tend to enjoy a reduced cost of debt and a larger supply of deposits (and other financing) than other banks, and creditors of TBTF banks tend to suffer fewer consequences for elevations in risk. All of this suggests that financiers treat TBTF banks as if implicit government guarantees exist. Thus, this study examines whether there is empirical evidence that depositors discipline banks who adopt $D L L P$ differently depending on whether the bank is TBTF or not. The expectation is that non-TBTF banks will be disciplined more severely than TBTF banks.

This study contributes to prior studies on market discipline in several ways. First, prior studies have examined the outsider's monitoring effect on banks' information quality. For example, $\mathrm{Wu}$ and Bowe (2012) examine evidence from the Chinese banking sector and find that the deposit growth rate is sensitive to bank fundamentals and the sensitivity increases as banks' information disclosures increase. Nier and Baumann (2006) find crosscountry evidence that higher information disclosure and a higher uninsured funding ratio lead banks to choose a higher capital buffer for a given asset risk. Our work extends their work. These studies measure information quantity using a disclosure index. They construct their disclosure index by recording whether or not a bank provides particular kinds of accounting information in various categories of the Bankscope database. So their focus is on the quantity of information the debtor provides. Our study investigates depositors' 
reactions to banks' discretionary accounting practices. Thus, our focus is on creditors' perceptions of and reactions to information quality.

Second, Gallemore (2016) finds that banks' opacity, as measured by delayed expected loan loss recognition, is related to a higher likelihood of regulatory forbearance, and that forbearance is more pronounced for systemically important banks. The idea is that if a troubled bank is successful in hiding its poor financial condition from the public (i.e., non-regulator outsiders) through opacity, regulators may conclude that this enables them to give the troubled bank time to correct its problems, rather than applying some of the regulatory options available to them. Forbearance like this avoids costly regulatory intervention and the system-wide damage (e.g., contagion; bank runs on financially healthy banks) that can occur in the event of a regulator taking publicly observable action against an important bank. While our study differs from Gallemore's (2016) discussion. We focus on whether outside depositors react to banks' loan loss provisioning behavior. We obtain the result that depositors appear to respond to loan loss provisioning behavior by punishing banks that act badly - in other words, action taken by banks to obscure financial realities is taken by the market as risk-elevating. This calls into question the idea that opacity helps troubled banks buy time to address their problems, and similarly, calls in to question the idea that opacity gives regulators grounds for exercising forbearance.

Third, a substantial body of literature questions whether large banks are subjected to weaker market discipline than other banks because large banks are protected by explicit or implicit government guarantees. Our study contributes to this literature by providing empirical support for the idea that market discipline is diminished for large banks. We find that within the non-TBTF banks, depositors react sensitively to $D L L P$ during both the crisis 
and non-crisis periods. The reaction is even stronger during the crisis period. However, for the TBTF banks, depositors react sensitively to $D L L P$ practices during the non-crisis period, but not during the crisis period. Our results are similar to the findings from Berger and Turk-Ariss (2015). They find that during the crisis period from 2008 to 2009 creditors in large U.S. banks were less sensitive to banks' risk indicators. This result can be explained by the effect to a perceived higher likelihood of government bailouts for the larger banks during the crisis period. In addition, we also find that the U.S. banks that received explicit government bailout funds during the crisis period were less punished for their DLLP practices than the banks that did not receive bailout funds. This evidence further confirms the notion that market discipline becomes weaker when banks appear to be protected by government guarantees. Thus, this study provides additional empirical evidence concerning the effects of implicit government guarantees.

In Section 3.2, we review the relevant literature. In Section 3.3, we discuss our empirical estimation methods, including measures and regression models. In Section 3.4, we discuss our empirical results. We conclude in Section 3.5.

\subsection{Literature review and hypothesis development}

\subsubsection{Depositors' discipline}

When banks assume additional risk depositors may punish them by withdrawing deposits or requiring higher interest rates (Berger, 1991; Martinez Peria and Schmukler, 2001). If depositors rationally withdraw their deposits or require higher interest rates based on banks' true riskiness, depositor discipline is effective. Effective market discipline can be beneficial to financial markets in several ways. First, if there is a credible threat to banks 
that depositors might initiate a large-scale withdrawal of funds - i.e., initiate a bank run in response to excessive risk-taking, banks may be more inclined to be more prudent about the risks they take than if this credible threat did not exist (Diamond and Dybvig, 1983). Second, the exercise of depositor discipline leads to deposits gravitating toward the more efficient banks. Third, depositor discipline may reduce governments' costs of monitoring banks and make it less likely they will need to bail out banks during financial crises.

If depositors' reactions become disconnected from a rational assessment of banks' true riskiness, the consequences can be negative. On the one hand, when depositors overreact to bank risk-taking, inefficient bank runs may happen. On the other hand, when depositors underreact (or remain indifferent) to bank risk-taking behavior, banks may have moral hazard incentives to increase their riskiness to levels that exceed what stakeholders would prefer, or to take risks that are not justified by the expected returns. Depositors may underreact (or remain indifferent) to bank risk-taking behavior if they believe that implicit government guarantees exist.

One stream of empirical literature on depositor discipline examines whether riskier banks pay higher interest rates on deposits. For example, empirical evidence from the large, uninsured certificates of deposits ("CD") market shows that higher bank risk-taking is associated with higher interest costs on CDs of U.S. banks (e.g., Ellis and Flannery, 1992; Brewer and Mondschean, 1994; and Cook and Spellman, 1994).

Another stream of empirical literature shows that the amount of uninsured deposits declines as a bank's risk increases. For example, Goldberg and Hudgins (1996) find that the level of uninsured deposits of failing U.S. savings and loan associations ("S\&Ls") was decreasing during the period 1986-1989. These failing S\&Ls attracted fewer uninsured 
deposits in the period preceding failure than the non-failing S\&Ls did. Park and Peristiani (1998) find that riskier thrifts paid higher interest rates on uninsured deposits and attracted fewer uninsured deposits during the period 1987-1991. The quantity effect was stronger than the interest rate effect. Billett, Garfinkel, and O'Neal (1998) find Moody's downgrades increase banks' reliance on insured deposits. Jordan (2000) finds that the levels of Jumbo CDs and small CDs were decreasing two years before bank failures, suggesting that uninsured depositors do react to deterioration in bank conditions. Maechler and McDill (2006) find that uninsured depositors are more sensitive to changes in bank fundamentals in banks with low equity capital. Hasan, Jackowicz, Kowalewski, and Kozlowski (2013) investigate foreign-owned banks in European countries and find that the 2007-2009 financial crisis did not change the sensitivity of deposit growth rates to banks' performance indicators including ROA, capital ratio, and risky loans. But they do find depositors reacted more strongly to negative press rumors relating to the foreign-owned banks' parent companies.

In general, these empirical studies examine depositors' reactions to risk factors. These factors can be bank financial statement indicators such as leverage, non-performing loans, volatility in ROA, etc. They can also be a single risk measure, such as balance-sheetbased Z-score, or market-data-based measures such as return volatility, Merton (1974)'s distance-to-default, Value-at-Risk, or rating agencies' credit ratings. In this study, in addition to the widely documented risk factors, we examine depositors' reactions to discretionary accounting practices. 


\subsubsection{Do investors react to poor financial reporting quality?}

Typically, firm managers possess private information concerning the firm information that current and prospective outsider investors do not have. Thus, information asymmetry exists between managers and outside investors. Managers can use their informational advantage to act opportunistically as they adopt discretionary accounting practices. Discretionary accounting practices involve the application of management discretion to determine financial reporting to outsiders, so what is reported deviates from what would be reported under generally accepted accounting principles. Because these practices can be arbitrary and self-serving for management, they tend to obscure fair presentation of financial results or financial position. The adoption of discretionary accounting practices, therefore, tends to reduce the quality of information available to outsider investors (Richardson, 2000).

The theoretical literature has shown that poor information quality can increase a firm's funding costs. This arises because poor information quality increases information uncertainty, which is costly for investors to resolve. Diamond (1985) shows that if firms choose to disclose more information, the costs of individual investors to gather private information can be reduced. Further, investors may ask for a lower risk premium for more transparent firms. Easley and O'Hara (2004) note that investors hold different levels of information concerning the firm. Informed investors know private information. When new information arrives, informed investors will exploit it and the equilibrium price of the firm's shares will also change. Then, less informed investors will make correct inferences about this private information from prices. When less informed investors recognize that 
they are at an informational disadvantage for a particular asset, they will hold a smaller quantity of that asset or ask for a higher rate of return.

Leuz and Verrecchia (2004) consider the role of financial reporting information quality in aligning firms to investors and their investment decisions. In their model, investors determine the price of projects based on information provided by the firm. Firms choose projects that maximize market value as determined by investors. Therefore, the quality of a firm's information affects the firm's investment choice, and the firm's investment choice affects the level of expected cash flows. When unexpected cash flows occur, investors recognize that the firm is providing low quality information and therefore charge a higher required return as compensation.

The empirical literature has examined the association between information quality and firms' cost of equity. Most of the evidence shows that lower information disclosure is related to a higher cost of equity (e.g., Botosan, 1997; Sengupta, 1998; Hribar and Jenkins, 2004; Francis, LaFond, Olsson, and Schipper, 2005; Francis, Nanda, Olsson, 2008), confirming that lower disclosure quality is associated with greater information uncertainty among investors in the equity markets. To compensate for bearing information uncertainty risk, equity investors ask for a higher rate of return, resulting in higher equity cost to the firm. One exception to this evidence is from Botosan and Plumlee (2002), who find that the cost of equity is positively related to the level of timely disclosures. They suggest that greater timely disclosures may increase a cost of equity via increased stock price volatility.

In addition to the evidence on the relation between information quality and equity returns, some studies also find that as firms' accounting information quality decreases, the risk of equity price crashes increases (e.g., Jin and Myers, 2006; Hutton, Marcus, and 
Tehranian, 2009, and Cohen and Cornett, 2014). The evidence shows that if firm managers stop concealing negative information and eventually release accumulated negative information, equity market investors will respond to the negative information dramatically.

Empirical studies have also investigated the association between information quality and cost of debt. Firms' ability to generate future cash flows is critical to ensure the payment of interest and principal to creditors. The quality of accounting information affects creditors' estimation of future cash flows (Ge and Kim, 2014). Bharath, Sunder, and Sunder (2008) find that firms with poor accounting quality are associated with more stringent debt contracting terms. Francis, LaFond, Olsson and Schipper (2005) find that firms with poor accounting quality are associated with a higher cost of debt, which is measured by the overall interest expenses associated with firms' debt. Prevost, Rao and Skousen (2008) find that firms with poor accounting quality are associated with higher corporate bond yield spreads. Ge and Kim (2014) find that firms that practice a high level of earnings management by altering the timing and scale of operating decisions are associated with lower credit ratings and higher bond yield spreads. Overall, this evidence implies that credit rating agencies and creditors see poor accounting information (or the adoption of a high level of discretionary accounting practices) as a credit-risk-increasing factor, which therefore leads to elevated risk premiums.

These empirical findings are consistent with the model from Duffie and Lando (2001). They show that if firms reveal perfect information to outside creditors, the default is priced based on firm fundamentals. In contrast, if the creditors cannot observe the firms' assets directly, and only get periodical delayed and noisy accounting report information, the default is priced based on both the fundamental and the imperfect information available 
to the creditors. So the compensation for creditors includes not only the credit risk premium from the firms' fundamental characteristics', but also the credit risk premium from the imperfect information.

Banks tend to be more opaque than other types of firms because banking, by its nature, is a complex business. Morgan (2002) finds that banks' riskiness is difficult to observe and that outside rating agencies disagree more on banks' bond issues than they do for other businesses. Additionally, banks are protected by the government by deposit insurance and have a history of being bailed out during periods of crisis. Consequently, creditors may not respond to banks' information risk as sensitively as they do for other businesses. Wu and Bowe (2012) examine evidence from the Chinese banking sector and find that the deposit growth rate is sensitive to bank fundamentals and the sensitivity increases as banks' information disclosures increase. Nier and Baumann (2006) find crosscountry evidence that higher information disclosure and a higher uninsured funding ratio lead banks to choose a higher capital buffer for a given asset risk. By contrast, Gilbert and Vaughan (2001) examine depositors' reactions to enforcement actions announced by federal bank supervisors in the 1990s. These actions, in effect, reveal to the public confidential information possessed by the banks' supervisors. While information revealed in this way could create a channel through which depositors could exert discipline on banks, the results show no evidence of unusual deposit withdrawals following the announcements of enforcement actions, indicating that such actions do not appear to spark bank runs, nor do they appear to enhance depositor discipline.

Overall, the extant theoretical literature shows that poor information disclosure quality tends to increase information uncertainty, resulting in higher funding costs because 
investors require compensation for the information uncertainty. However, the empirical evidence on the relationship between disclosure quality and investors' reactions is mixed, particularly in the banking sector. The mixed evidence suggests that the association between disclosure and investors' reactions might depend on factors that are additional to those that have been examined so far.

\subsubsection{The relationship between too-big-to-fail expectations and market discipline}

When investors conclude that a bank is so systemically important that it is likely to receive government support should it find itself in distress, an implicit government guarantee is said to exist even though no guarantee has been formally established or documented. Such banks are regarded as TBTF, and thus, tend to be subjected to reduced levels of market discipline. Because there are reduced consequences for these banks for elevated risk-taking, they are exposed to moral hazard incentives to increase risk-taking.

Many studies examine whether market discipline exists for large banks by comparing funding cost differences between TBTF banks and non-TBTF banks (see a survey from Kroszner, 2016). TBTF banks are typically defined as large banks with assets levels above a certain cutoff level.

Among the funding cost comparison studies, funding costs are usually measured by bond spreads (e.g., Santos, 2014; Lester and Kumar, 2014; Acharya, Anginer, and Warburton, 2016), CDS spreads (e.g., Demirgüc-Kunt and Huizinga, 2010), or interest expenses on deposits (e.g., Baker and McArthur, 2009; Jacewitz and Pogach, 2018). Many studies find that large banks have funding cost advantages over small banks after controlling for banks' risk factors, indicating that creditors ask for lower risk premiums for 
large banks. The argument is that lower risk premiums are consistent with perceptions of implicit government guarantees (e.g., Santos, 2014; Demirgüc-Kunt and Huizinga, 2010).

Two studies focus on quantity of funding measures. Beyhaghi, Souza, and Roberts (2014) report that the wholesale deposit growth rate was higher for the six largest Canadian banks than for the smaller banks during the period 1990-2010. Berger and Turk-Ariss (2015) find that during the crisis period from 2008 to 2009 investors in uninsured deposits in large U.S. banks were less sensitive to banks' risk indicators, including the equity ratio and the level of non-performing loans, than were depositors in smaller banks. They attribute the effect to a perceived higher likelihood of government bailouts for the larger banks.

Overall, empirical evidence shows that perceptions of implicit government guarantees affect creditors' reactions. This study is different from previous TBTF studies in that we do not directly examine the relationship between a TBTF effect and depositors' reactions. Instead, we examine how depositors react to the way in which banks exercise accounting discretion, and we examine whether this reaction is different for TBTF banks versus non-TBTF banks.

\subsubsection{Testable hypotheses}

Based on reviewed theories and empirical evidence, we develop two testable hypotheses. The first one is developed to test the relationship between the level of discretionary accounting practices and uninsured deposit growth rates. The second one is developed to test the relationship between TBTF expectations and depositors' risk sensitivity. 
First, the expectation is that in the absence of perceptions of government guarantees, depositors will punish banks for their elevated risk-taking behavior. Elevated bank riskiness should be associated with reduced levels of deposit growth rates and elevated levels of deposit interest rates. The risk factor we examine is the adoption of discretionary accounting practices. It is a risk factor because it increases creditors' information uncertainty about the future cash flows of the bank, and therefore increases information uncertainty about the banks' ability to make interest and principal repayments. Therefore, all else being equal, a high level of discretionary accounting practices should be associated with a reduced level of deposit growth rates.

\section{H1. Banks' adoption of discretionary accounting practices has a negative} effect on uninsured deposit growth rates.

Second, the expectation is that the exercise of depositors' discipline will be attenuated when implicit government guarantees are perceived to exist. Therefore, when depositors see banks as $\mathrm{TBTF}^{16}$, they react less sensitively to indicators of elevated risk in those banks than they do for non-TBTF banks. Sensitivity is reduced because depositors conclude that their deposits are protected by implicit government guarantees.

H2. The negative effect of bank riskiness on uninsured deposit growth rates is weaker for TBTF banks than for non-TBTF banks.

\footnotetext{
${ }^{16}$ Or equivalently, when depositors conclude that governments see banks as TBTF.
} 


\subsection{Empirical methodology}

\subsubsection{Measuring $\quad$ DLLP}

In this study, banks' adoption of discretionary accounting practices is measured by $D L L P$. Recall that we use the term $D L L P$ to denote the difference between an observed provision and a model-determined, non-discretionary (or normal) provision.

Loan loss provisioning is a key accounting practice that directly influences banks' earnings and reflects the risk attributes of banks' loan portfolios (Beatty and Liao, 2014). Bank managers may use $D L L P$ to smooth income, signal portfolio quality strength, and manage their capital ratios with the purpose of obtaining short-term benefits. $D L L P$ may induce greater investor uncertainty about banks' intrinsic value. Managers may opportunistically use $D L L P$ to conceal or delay releasing negative information, resulting in a reduction in bank transparency (Bushman and Williams, 2015).

To estimate the DLLP, one may start with a Loan Loss Provision (LLP) model: $L L P_{i, t}=\alpha_{0}+\alpha_{1}$ Predictors $+\varepsilon_{i, t}$. The fitted value $\widehat{L L P}_{i, t}$ from the model captures the notionally correct (or normal) loan loss provisions, which result from a bank's normal operations and are free from management manipulation. The residuals $\varepsilon_{i, t}=L L P_{i, t}$ $\widehat{L L P} \widehat{C}_{i, t}$ capture the discretionary (or abnormal) loan loss provisions denoted here as $D L L P$. This measure, in effect, quantifies bank managers' loan loss manipulation to achieve goals such as meeting regulatory capital requirements or smoothing earnings.

Estimating discretionary loan loss provisions requires us to determine predictors for the non-discretionary (or normal) loan loss provisions. The earnings management literature in non-bank sectors usually adopts some commonly used discretionary accruals models. However, in the banking literature, there is no consensus on how to best model 
discretionary provisions (Beatty and Liao, 2014). Different discretionary provision models employ different "non-discretionary" predictors. For example, some studies treat the net charge-offs as the non-discretionary component and include the net charge-offs as a predictor in the LLP model. Other studies consider the net charge-offs as the discretionary component and exclude this variable from the LLP model.

Beatty and Liao (2014) identify a set of common factors used in loan loss provision models and construct four LLP models using these common factors shown as equations (1) to (4) below. Each model generates its own DLLP measure. Since Beatty and Liao (2014) see restating financial results and receiving SEC comment letters relating to loan loss provisioning as the most direct evidence of provision manipulation, they examine which $D L L P$ model produces results that are most closely correlated with these phenomena. Their test results show that, according to this metric, model (1) performs best.

$$
\begin{aligned}
& L L P_{i, t}=\alpha_{0}+\alpha_{1} \Delta N P A_{i, t+1}+\alpha_{2} \Delta N P A_{i, t}+\alpha_{3} \Delta N P A_{i, t-1}+\alpha_{4} \Delta+\alpha_{5} \operatorname{SIZE}_{i, t-1}+ \\
& \alpha_{6} \Delta L O A N_{i, t}+\alpha_{7} \Delta G D P_{t}+\alpha_{8} \operatorname{CSRET}_{t}+\alpha_{9} \Delta U N E M P_{t}+\varepsilon_{i, t} \\
& L L P_{i, t}=\alpha_{0}+\alpha_{1} \Delta N P A_{i, t+1}+\alpha_{2} \Delta N P A_{i, t}+\alpha_{3} \Delta N P A_{i, t-1}+\alpha_{4} \Delta N P A_{i, t-2}+\alpha_{5} S \mathrm{IZE}_{i, t-1}+ \\
& \alpha_{6} \Delta L O A N_{i, t}+\alpha_{7} \Delta G D P_{t}+\alpha_{8} \operatorname{CSRET}_{t}+\alpha_{9} \Delta U N E M P_{t}+\alpha_{10} C_{i, t}+\varepsilon_{i, t} \\
& L L P_{i, t}=\alpha_{0}+\alpha_{1} \Delta N P A_{i, t+1}+\alpha_{2} \Delta N P A_{i, t}+\alpha_{3} \Delta N P A_{i, t-1}+\alpha_{4} \Delta N P A_{i, t-2}+\alpha_{5} \operatorname{SIZE}_{i, t-1}+ \\
& \alpha_{6} \Delta L O A N_{i, t}+\alpha_{7} \Delta G D P_{t}+\alpha_{8} \operatorname{CSRET}_{t}+\alpha_{9} \Delta U N E M P_{t}+\alpha_{10} A L W_{i, t-1}+\varepsilon_{i, t} \\
& L L P_{i, t}=\alpha_{0}+\alpha_{1} \Delta N P A_{i, t+1}+\alpha_{2} \Delta N P A_{i, t}+\alpha_{3} \Delta N P A_{i, t-1}+\alpha_{4} \Delta N P A_{i, t-2}+\alpha_{5} S I Z E_{i, t-1}+ \\
& \alpha_{6} \Delta L O A N_{i, t}+\alpha_{7} \Delta G D P_{t}+\alpha_{8} \operatorname{CSRET}_{t}+\alpha_{9} \Delta U N E M P_{t}+\alpha_{10} A L W_{i, t-1}+\alpha_{11} \operatorname{CO}_{i, t}+\varepsilon_{i, t}
\end{aligned}
$$


In model (1), $L L P_{i, t}$ is the loan loss provision in quarter $t$ divided by total loans in quarter $t-1$ for bank $i . \Delta N P A_{i, t}$ is the change in non-performing assets between quarter $t$ and quarter $t-1$ divided by total loans in quarter $t-1$ for bank $i$. Future and historical $\triangle N P A_{i, t+1}, \Delta N P A_{i, t-1}$, and $\triangle N P A_{i, t-2}$ are included in the model because banks may use forward or backward non-performing loan information to estimate loan loss provisions. This method assumes that on average banks can correctly estimate future and current nonperforming loans, so it uses the actual future and current non-performing loans to capture the predicted values of non-performing loans.

$\operatorname{SIZE}_{i, t-1}$ is the natural log of total assets in quarter $t-1$ for bank $i$. This variable is included because banks of different sizes may be subjected to different levels of external monitoring. $\triangle L O A N_{i, t}$ is the change in total loans between quarter $t$ and quarter $t-1$ divided by total loans in quarter $t-1$ for bank $i$. It is included because loan loss provisions may be higher when a bank expands its lending to more borrowers with lower credit quality than existing borrowers.

Among the macro factors, $\triangle \mathrm{GDP}$ is the percentage change in GDP between quarter $t$ and quarter $t-1$. CSRET is the return on the Case-Shiller Real Estate Index between quarter $t$ and quarter $t-1$. $\triangle \mathrm{UNEMP}$ is the percentage change in unemployment rates between quarter $t$ and quarter $t-1$. These three variables capture the macro-level factors that may be associated with loan loss provisions.

In addition to the factors included in model (1), models (2) to (4) also include $\mathrm{CO}_{i, t}$, defined as the net charge off divided by lagged total loans in quarter $t$ for bank $i$, and $A L W_{i, t-1}$, defined as the loan loss allowance divided by total loans in quarter $t-1$ for bank $i$ as predictors. The rationale for including $A L W$ is that if a bank is carrying a sufficiently 
high level of loan loss allowance due to recording allowances in the past, it may recognize only a small change in loan loss allowances (and therefore only a small loan loss provision in the income statement) in the current period. Since $C O$ amounts to a reversal of a previously recorded allowance combined with a write-off of the loan balance, any difference between the loan balance and the allowance affects the loan loss provision in the income statement.

Since Beatty and Liao's (2014) test results show that model (1) outperforms the other models in creating the best $D L L P$ measure, we do the main part of our analysis using this model. As a robustness check, we also examine whether the other DLLP measures deliver similar results.

\subsubsection{Empirical strategy}

To begin the baseline regression analysis, we divide the whole sample into two subgroups: TBTF banks and non-TBTF banks. We allocate banks to these groups based on bank size. For each quarter-year, banks above the upper $10^{\text {th }}$ percentile of total assets are treated as TBTF banks and the rest as non-TBTF banks. ${ }^{17}$ Within each group, we first estimate equation (5) with a time-fixed OLS model. ${ }^{18}$ The time fixed effect method is used to control for the influence of aggregate time trends over quarters.

Uninsured_Deposit_Growth_Rate $e_{i, t}=\beta_{0}+\beta_{1} D L L P_{i, t-1}+\beta_{2} T I E R 1_{i, t-1}+$ $\beta_{3} N P A_{i, t-1}+\beta_{4}$ RealEstate $_{i, t-1}+\beta_{5}$ Non_Interest_Income $_{t-1}+$

${ }^{17}$ Following Acharya, Anginer, and Warburton (2016), we started with $10^{\text {th }}$ percentile as the cut-off. In the robustness check part, we also try the other size cut-offs.

${ }^{18}$ Due to the large sample size and limited computing power, we do not use the firm-fixed effects model, and we use the OLS model with time-fixed effects following Acharya, Anginer, and Warburton (2016). We also perform the analysis with random effect, the results are robust. 


$$
\begin{aligned}
& \beta_{6} \text { Non_Deposit_Funding }_{t-1}+\beta_{7} \text { Liquidity_Ratio }_{i, t-1}+
\end{aligned}
$$

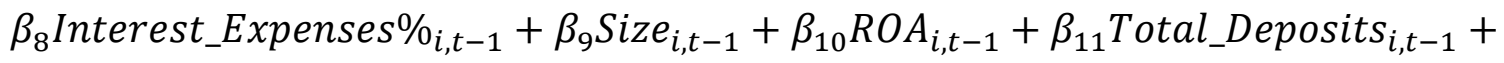

$$
\begin{aligned}
& \beta_{12} \text { Tbill_3M } M_{t-1}+\beta_{13} T 10 Y 3 M_{t-1}+\beta_{14} \text { Ted_Rate } \text { R }_{t-1}+\beta_{15} t+\varepsilon_{i, t}
\end{aligned}
$$

The dependent variable Uninsured_Deposit_Growth_Rate $e_{i, t}$ is defined as $\frac{\text { Uninsured Deposit }_{t}-\text { Uninsured Deposit }_{t-1}}{\text { Uninsured Deposit }} t_{-1}$, where Uninsured Deposit is computed following the steps in Berger and Turk-Ariss $(2015)^{19}$.

There is a potential endogeneity problem between past uninsured deposit amounts and $D L L P$ arising from the possibility that banks that have experienced low uninsured deposit growth rates in the past have had an incentive to present loan loss provisions that make the bank look more attractive to depositors. Therefore, we use the lagged variable $D L L P_{i, t-1}$ in equation (5) to control for the potential endogeneity.

In terms of control variables, following Berger and Turk-Ariss (2014), Beyhaghi, Souza, and Roberts (2014), and Acharya, Anginer, and Warburton (2016), we include a set of financial indicators to represent banks' capital adequacy, asset quality, liquidity, income structure, funding structure and other characteristics. TIERl (Tier 1 capital ratio) is included to control for capital adequacy. NPA (the ratio of non-performing loans to total

\footnotetext{
${ }^{19}$ Based on Berger and Turk-Ariss (2015), we calculate the quantity of uninsured deposits in the following way:

For the period before 2006Q2, uninsured deposits $=($ Amount of Deposits Accounts $>\$ 100 \mathrm{~K})-\$ 100 \mathrm{~K} *$ (Number of Deposit Accounts $>\$ 100 \mathrm{~K})+$ Foreign Deposits.

For the period between 2006Q2 to 2009Q2, uninsured deposits $=($ Amount of Deposits $>\$ 100 \mathrm{~K})-\$ 100 \mathrm{~K} *$ (Number of Deposit Accounts $>\$ 100 \mathrm{~K})+($ Amount of Retirement Deposits Accounts $>\$ 250 \mathrm{~K})-\$ 250 \mathrm{~K} *$ (Number of Retirement Deposits Accounts $>\$ 250 \mathrm{~K})+$ Foreign Deposits.

For the period from 2009Q3 and onward: uninsured deposits $=($ Amount of Deposits $>\$ 250 \mathrm{~K})-\$ 250 \mathrm{~K} *$ (Number of Deposit Accounts $>\$ 250 \mathrm{~K})+($ Amount of Retirement Deposits Accounts $>\$ 250 \mathrm{~K}$ ) $-\$ 250 \mathrm{~K} *$ (Number of Retirement Deposits Accounts $>\$ 250 \mathrm{~K})+$ Foreign Deposits.
} 
loans) and RealEstate\% (real estate loans scaled by total loans) are used to control for asset riskiness. Non_Interest_Income (total non-interest income divided by the sum of total interest income and non-interest income) is included to control for income arising from non-traditional banking activities (Demirguc-kunt, Huizinga, 2010). Non_Deposit_Funding (the ratio of non-deposit funding to total assets) is included to control for the nature of the banks' funding source. Liquidity_Ratio (the ratio of cash and balances due from depository institutions plus the held-to-maturity U.S. Treasury securities to total assets) is included to control for asset liquidity. $R O A$ (net income divided by total assets) is included to control for earnings. Interest_Expenses\% (the ratio of total interest expense on deposits to total deposits) is included to control for the level of interest rate paid on deposits. Additionally, we include Size (natural log of total assets) and Total_Deposits (natural log of the sum of total deposits, including both uninsured and insured deposits) to control for bank scale.

We also include three macro-control variables: Tbill_3m (3-month Treasury bill rate), T10Y3M (the term spread, measured as the difference between 10-year bond yields and the 3-month Treasury bill rate), and TED_Spread (the market funding liquidity measure, defined as the difference between the 3-month LIBOR rate and the 3-month Treasury bill rate). Finally, $t$ at the end of the regression models stands for the quarter time fixed effect.

As robustness checks, we also examine the relationship of $D L L P$ to Insured_Deposit_Growth_Rate and Interest_Expenses\% by estimating equations (6) and (7) respectively. 


$$
\begin{aligned}
& \text { Insured_Deposit_Growth_Rate }_{i, t}=\beta_{0}+\beta_{1} D_{L L P} P_{i, t-1}+\beta_{2} \text { TIER } 1_{i, t-1}+\beta_{3} N P A_{i, t-1}+ \\
& \beta_{4} \text { RealEstate } \%_{i, t-1}+\beta_{5} \text { Non_Interest_Income } t_{-1}+ \\
& \beta_{6} \text { Non_Deposit_Funding }_{t-1}+\beta_{7} \text { Liquidity_Ratio }_{i, t-1}+
\end{aligned}
$$

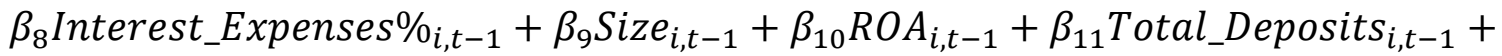

$$
\begin{aligned}
& \beta_{12} \text { Tbill_3M } M_{t-1}+\beta_{13} T 10 Y 3 M_{t-1}+\beta_{14} \text { Ted_Rate } \text { T }-1_{1}+\beta_{15} t+\varepsilon_{i, t} \\
& \text { Interest_Expenses } \%_{i, t}=\beta_{0}+\beta_{1} D L L P_{i, t-1}+\beta_{2} \text { TIER } 1_{i, t-1}+\beta_{3} N P A_{i, t-1}+ \\
& \beta_{4} \text { RealEstate } \%_{i, t-1}+\beta_{5} \text { Non_Interest_Income }{ }_{t-1}+ \\
& \beta_{6} \text { Non_Deposit_Funding }_{t-1}+\beta_{7} \text { Liquidity_Ratio }_{i, t-1}+\beta_{8} \text { Size }_{i, t-1}+\beta_{9} \text { ROA }_{i, t-1}+ \\
& \beta_{10} \text { Total_Deposits }_{i, t-1}+\beta_{11} \text { Tbill_3 }_{t-1}+\beta_{12} \text { T10Y3M } M_{t-1}+\beta_{13} \text { Ted_Rate }_{t-1}+ \\
& \beta_{14} t+\varepsilon_{i, t}
\end{aligned}
$$

The dependent variable Insured_Deposit_Growth_Rate $e_{i, t}$ is defined as $\frac{\text { Insured Deposit }_{t} \text { Insured Deposit }}{t-1}$, where Insured Deposit is computed as total deposits minus the uninsured deposits. Interest_Expenses $\%$ is calculated as the ratio of total interest expense on deposits to total deposits. Ideally, one would use the interest expenses on uninsured deposits to examine the depositors' required risk premium. However, FFIEC 031/041 Call reports do not provide detailed information to calculate the variable of interest expenses on uninsured deposits. Therefore, we use a less accurate measure, the interest expenses on all deposits, to examine the risk premium. We include the same controls in equations (6) and (7) as those used in equation (5).

We expect that the insured deposit growth rate examined in equation (6) will react less sensitively to risk, as proxied by $D L L P$, than the uninsured deposit growth rate because 
of the protection provided by the deposit insurance. Insofar as interest expense is concerned, we expect reduced risk sensitivity apparent from equation (7) because the dependent variable is based on a combination of interest on insured and uninsured deposits, and we expect that interest rates on insured deposits will be relatively less sensitive to risk, as proxied by $D L L P$.

\subsection{Data and empirical results}

\subsubsection{Sample selection}

U.S. bank regulatory data can be collected from FFIEC 031/041 Call Reports for commercial banks or FR-Y-9C reports for bank-holding companies. However, only FFIEC 031/041 Call reports provide the detailed data needed to calculate the number of uninsured deposits. Therefore, we collect our data from FFIEC 031/041 Call Reports.

Appendix C lists all the variable definitions. The initial dataset includes 331,711 bank-quarter observations from 2001Q1 to 2010Q4. We choose this period because data before 2001Q1 does not include the information needed to calculate the Tier-1 capital ratio, which is an important asset riskiness indicator. Data after 2010Q4 is incomplete that it does not enable us to calculate non-performing loans, which is a key variable needed to estimate $D L L P$. Because the main variable of concern in this study is the uninsured deposit growth rate, we exclude banks that are not insured by Federal Deposit Insurance Corporation (FDIC). ${ }^{20}$ We also exclude observations with zero total assets, leaving 318,958 bankquarter observations.

\footnotetext{
${ }^{20}$ The banks that are not insured by FDIC can be foreign-owned institutions or branches operating in the U.S. These banks do not have the accounting data for several variables used in this study.
} 
We further exclude observations for banks involved in M\&A deals using the method introduced in Delis, Staikouras, and Tsoumas (2017). If a bank is identified in the FDIC's Reports of Structure Changes as a target or an acquirer in an M\&A deal, we exclude the bank-quarter observations for a -4 quarters to +4 quarters window around the effective date of the deal. The final sample size is reported in Table 3-3.

All the macro-level variables are obtained from FRED, which is the economic database maintained by the St. Louis Federal Reserve.

We winsorize all variables at the $0.5 \% / 99.5 \%$ level. ${ }^{21}$

\subsubsection{DLLP calculation}

We first estimate LLP models (1) to (4) to obtain the DLLP measures. Table 3-1 reports the OLS estimates of the predictors of the four LLP models. From Table 3-1, we see that the coefficients of all bank-level predictors are significant at the $1 \%$ level. Models (2) and (4), the two models with $C O$ as a predictor, show higher adjusted R-squared. This is not surprising given that the exercise of discretion in charge-offs is highly correlated with the exercise of discretion in loan loss provisions (Liu and Ryan, 2006; Beatty and Liao, 2014).

\footnotetext{
${ }^{21}$ We repeat the analysis with winsorizing data at $1 \% / 99 \%$ level and the empirical results are not affected. Frank and Goyal (2005) note that 'It is particularly common to winsorize each tail at $0.5 \%$ or $1 \%$ ' when they address the winsorizing practice in corporate finance literature.
} 
Table 3-1 Regression results of loan loss provision models

\begin{tabular}{|c|c|c|c|c|}
\hline & (1) & (2) & (3) & (4) \\
\hline (Intercept) & $-0.002 * * *(-22.108)$ & $-0.001 * * *(-20.731)$ & $-0.004 * * *(-57.272)$ & $0.000 * * *(-9.361)$ \\
\hline$\Delta N P A_{i, t+1}$ & $0.024 * * *(32.842)$ & $0.024 * * *(47.699)$ & $0.027 * * *(38.082)$ & $0.023 * * *(46.579)$ \\
\hline$\triangle N P A_{i, t}$ & $0.046 * * *(59.784)$ & $0.060 * * *(114.624)$ & $0.047 * * *(62.979)$ & $0.060 * * *(115.395)$ \\
\hline$\Delta N P A_{i, t-1}$ & $0.064 * * *(81.656)$ & $0.029 * * *(53.224)$ & $0.059 * * *(78.250)$ & $0.028 * * *(53.176)$ \\
\hline$\Delta N P A_{i, t-2}$ & $0.058 * * *(73.477)$ & $0.022 * * *(40.163)$ & $0.053 * * *(68.774)$ & $0.022 * * *(40.336)$ \\
\hline$S \operatorname{IZE}_{i, t-1}$ & $0.000 * * *(40.102)$ & $0.000 * * *(23.803)$ & $0.000 * * *(54.149)$ & $0.000 * * *(18.888)$ \\
\hline$\triangle L O A N_{i, t}$ & $0.002 * * *(23.260)$ & $0.006 * * *(100.787)$ & $0.003 * * *(37.216)$ & $0.006 * * *(99.062)$ \\
\hline $\operatorname{CSRET}_{t}$ & $0.001 * * *(3.106)$ & $0.001 * * *(2.672)$ & $0.001 * * *(2.900)$ & $0.001 * * *(2.714)$ \\
\hline$\triangle U N E M P_{t}$ & $0.004 * * *(26.804)$ & $0.002 * * *(20.182)$ & $0.004 * * *(28.686)$ & $0.002 * * *(19.377)$ \\
\hline$\Delta G D P_{t}$ & $-0.003 *(-1.841)$ & $0.001(0.736)$ & $-0.006 * * *(-4.631)$ & $0.002(1.638)$ \\
\hline$C O_{i, t}$ & & $0.830 * * *(543.836)$ & & $0.855 * * *(511.274)$ \\
\hline$A L W_{i, t-1}$ & & & $0.109 * * *(135.279)$ & $-0.022 * * *(-35.992)$ \\
\hline No. of obs. & 253647 & 253647 & 253647 & 253647 \\
\hline Adj. R-Squared & 0.071 & 0.571 & 0.134 & 0.573 \\
\hline
\end{tabular}

Notes: The table presents the regression results of LLP models (1) to (4). Appendix C provides all the variable definitions and data sources. Each column reports the coefficient estimates and t-statistics (in parentheses) of each model. All regression models are estimated with OLS. The sample period is 2001Q1 to 2010 Q4. $* * *, * *$, and $*$ represent $1 \%, 5 \%$, and $10 \%$ significance, respectively.

The residuals $\varepsilon_{i, t}=L L P_{i, t}-L \widehat{L P} P_{i, t}$ from each model represent the unexplained component of loan loss provisions. We use the absolute value of residuals $\left|\varepsilon_{i, t}\right|$ as indicators of $D L L P$ because both positive and negative residuals may reflect the use of $D L L P$ to augment the provision accounted for by the explanatory variables (Jiang, Levine, and Lin, 2017). So, the measure of $D L L P$ of bank $i$ at quarter $t$ is $D L L P_{i, t}=\left|\varepsilon_{i, t}\right|$. Following this method, we obtain $D L L P 1, D L L P 2, D L L P 3$, and DLLP4 from models (1) to (4) respectively.

To examine if the DLLPs from the four models are correlated with each other, we report the correlation coefficients of the four DLLP measures in Table 3-2. Overall, the correlation coefficients suggest that the four $D L L P$ measures are closely related to each other. DLLP1 is highly correlated with $D L L P 3$ with a correlation coefficient of 0.961 . 
$D L L P 2$ is highly correlated with DLLP4 with a correlation coefficient of 0.997 . The weakest correlation is found between DLLP1 and DLLP4. The correlation coefficient between these two $D L L P$ measures is 0.703 , which still signals a high correlation.

Table 3-2 DLLPs' correlation coefficients

\begin{tabular}{ccccr}
\hline & $D L L P 1$ & $D L L P 2$ & DLLP3 & DLLP4 \\
\hline DLLP1 & 1.000 & 0.705 & 0.961 & 0.704 \\
$D L L P 2$ & 0.705 & 1.000 & 0.728 & 0.997 \\
$D L L P 3$ & 0.961 & 0.728 & 1.000 & 0.718 \\
$D L L P 4$ & 0.704 & 0.997 & 0.718 & 1.000 \\
\hline
\end{tabular}

Notes: The table presents the correlation coefficients of four DLLP measures based on LLP models (1) to (4). $D L L P_{i, t}=\left|\varepsilon_{i, t}\right|$, where $\varepsilon_{i, t}$ is the residual from model (1) in Table 3-1. Similarly, $D L L P 2_{i, t}, D L L P 3_{i, t}$ and $D L L P 4_{i, t}$ are the absolute value of residuals from models (2), (3), and (4).

We use DLLP1 for the main analysis since model (1) is the preferred model according to Beatty and Liao (2014) and the results from Chapter 2. For robustness, and to examine if the results are sensitive to how we measure $D L L P$, we also examine if analyses using the other three $D L L P$ measures show similar results.

\subsubsection{Summary statistics and univariate analysis}

Table 3-3 reports summary statistics for the variables used in the baseline regression. We list the number of observations, maximum and minimum values, means, medians, and standard deviations across all banks in the sample. In addition, Table 3-4 reports the number of observations and mean values of the main bank-level variables separately for TBTF and non-TBTF banks, and the t-statistics for mean comparisons. 
Table 3-3 Summary statistics on bank and macro variables

\begin{tabular}{lcccccc}
\hline & $\mathrm{N}$ & Mean & Stdev & $25 \%$ & Median & $75 \%$ \\
\hline Uninsured_Deposit_Growth_Rate & 281421 & 0.099 & 0.470 & -0.078 & 0.027 & 0.158 \\
Insured_Deposit_Growth_Rate & 281889 & 0.027 & 0.110 & -0.011 & 0.010 & 0.035 \\
Interest expenses\% & 292543 & 0.006 & 0.003 & 0.004 & 0.005 & 0.007 \\
DLLP1 & 247085 & 0.002 & 0.003 & 0.001 & 0.001 & 0.002 \\
DLLP2 & 247085 & 0.001 & 0.002 & 0.000 & 0.001 & 0.001 \\
DLLP3 & 247085 & 0.002 & 0.003 & 0.000 & 0.001 & 0.002 \\
DLLP4 & 247085 & 0.001 & 0.002 & 0.000 & 0.001 & 0.001 \\
TIER1 & 291454 & 0.116 & 0.094 & 0.082 & 0.095 & 0.118 \\
NPA & 288481 & 0.013 & 0.020 & 0.002 & 0.007 & 0.017 \\
RealEstate\% & 292253 & 0.662 & 0.204 & 0.541 & 0.694 & 0.812 \\
Non_Interest_Income & 293856 & 0.121 & 0.122 & 0.061 & 0.096 & 0.144 \\
Non_Deposit_Funding & 294885 & 0.185 & 0.123 & 0.119 & 0.157 & 0.209 \\
Liquidity_Ratio & 291454 & 0.058 & 0.064 & 0.025 & 0.039 & 0.065 \\
Total_Assets(Size) & 295449 & 11.678 & 1.230 & 10.863 & 11.581 & 12.376 \\
ROA & 293882 & 0.003 & 0.005 & 0.002 & 0.003 & 0.004 \\
Total_Deposits & 293440 & 11.460 & 1.232 & 10.681 & 11.396 & 12.173 \\
Tbill_3M & 295449 & 0.022 & 0.016 & 0.009 & 0.017 & 0.037 \\
T10Y3M & 295449 & 1.960 & 1.270 & 0.775 & 2.524 & 3.076 \\
TED_Rate & 295449 & 0.512 & 0.475 & 0.208 & 0.298 & 0.521 \\
\hline Notes: The table & 54509
\end{tabular}

Notes: The table reports the basic summary statistics for the main variables in models (5), (6) and (7), including the number of observations (bank-quarter) after removing the missing values, means, standard deviations, $25 \%$ and $75 \%$ quantiles, and medians. The results are reported after winsorizing. The sample period is 2001Q1 to 2010Q4. Appendix C provides all the variable definitions and data sources. 
Table 3-4 Summary statistics on non-TBTF banks and TBTF banks ${ }^{22}$

\begin{tabular}{|c|c|c|c|c|c|c|c|c|c|}
\hline & \multicolumn{4}{|c|}{ Non-TBTF banks } & \multicolumn{4}{|c|}{ TBTF banks } & \multirow{2}{*}{$\begin{array}{l}\begin{array}{l}\text { Group- } \\
\text { Mean } \\
\text { comparison }\end{array} \\
\mathrm{T}- \\
\text { statistics } \\
\end{array}$} \\
\hline & $\mathrm{N}$ & Mean & Median & Stdev & $\mathrm{N}$ & Mean & Median & Stdev & \\
\hline Unisured_Deposit_Growth_Rate & 253758 & $1.032 \mathrm{E}-01$ & $2.714 \mathrm{E}-02$ & $4.839 \mathrm{E}-01$ & 27663 & $5.821 \mathrm{E}-02$ & 2.799E-02 & $3.089 \mathrm{E}-01$ & 21.528 \\
\hline Insured_Deposit_Growth_Rate & 254246 & $2.724 \mathrm{E}-02$ & $9.624 \mathrm{E}-03$ & $1.109 \mathrm{E}-01$ & 27643 & $2.159 \mathrm{E}-02$ & $8.736 \mathrm{E}-03$ & $1.060 \mathrm{E}-01$ & 8.3684 \\
\hline Interest expenses $\%$ & 263279 & $5.648 \mathrm{E}-03$ & $5.303 \mathrm{E}-03$ & $2.492 \mathrm{E}-03$ & 29264 & $5.494 \mathrm{E}-03$ & $5.091 \mathrm{E}-03$ & $2.692 \mathrm{E}-03$ & 9.3552 \\
\hline$D L L P 1$ & 225787 & $1.523 \mathrm{E}-03$ & $9.760 \mathrm{E}-04$ & $2.710 \mathrm{E}-03$ & 21298 & $2.143 \mathrm{E}-03$ & $1.365 \mathrm{E}-03$ & $3.615 \mathrm{E}-03$ & -24.401 \\
\hline DLLP2 & 225787 & $1.038 \mathrm{E}-03$ & $5.010 \mathrm{E}-04$ & $1.917 \mathrm{E}-03$ & 21298 & $1.074 \mathrm{E}-03$ & $5.030 \mathrm{E}-04$ & $2.059 \mathrm{E}-03$ & -2.4651 \\
\hline$D L L P 3$ & 225787 & $1.498 \mathrm{E}-03$ & $8.520 \mathrm{E}-04$ & $2.653 \mathrm{E}-03$ & 21298 & $1.936 \mathrm{E}-03$ & $1.188 \mathrm{E}-03$ & $3.161 \mathrm{E}-03$ & -19.568 \\
\hline DLLP4 & 225787 & $1.041 \mathrm{E}-03$ & $5.140 \mathrm{E}-04$ & $1.907 \mathrm{E}-03$ & 21298 & $1.080 \mathrm{E}-03$ & $5.120 \mathrm{E}-04$ & $2.070 \mathrm{E}-03$ & -2.65 \\
\hline TIER 1 & 264772 & $1.186 \mathrm{E}-01$ & $9.620 \mathrm{E}-02$ & $9.659 \mathrm{E}-02$ & 26682 & $9.488 \mathrm{E}-02$ & 8.490E-02 & $5.344 \mathrm{E}-02$ & 62.969 \\
\hline$N P A$ & 261935 & $1.342 \mathrm{E}-02$ & $6.728 \mathrm{E}-03$ & $1.989 \mathrm{E}-02$ & 26546 & $1.412 \mathrm{E}-02$ & $6.615 \mathrm{E}-03$ & $2.216 \mathrm{E}-02$ & -4.9732 \\
\hline RealEstate $\%$ & 262919 & $6.576 \mathrm{E}-01$ & $6.865 \mathrm{E}-01$ & $1.998 \mathrm{E}-01$ & 29334 & $6.983 \mathrm{E}-01$ & 7.543E-01 & $2.376 \mathrm{E}-01$ & -28.233 \\
\hline Non_Interest_Income & 264544 & $1.155 \mathrm{E}-01$ & $9.338 \mathrm{E}-02$ & $1.174 \mathrm{E}-01$ & 29312 & $1.675 \mathrm{E}-01$ & $1.325 \mathrm{E}-01$ & $1.507 \mathrm{E}-01$ & -57.182 \\
\hline Non_Deposit_Funding & 265537 & $1.781 \mathrm{E}-01$ & $1.523 \mathrm{E}-01$ & $1.165 \mathrm{E}-01$ & 29348 & $2.496 \mathrm{E}-01$ & $2.109 \mathrm{E}-01$ & $1.574 \mathrm{E}-01$ & -75.62 \\
\hline Liquidity_Ratio & 264772 & $6.013 \mathrm{E}-02$ & $3.966 \mathrm{E}-02$ & $6.526 \mathrm{E}-02$ & 26682 & 4.184E-02 & $2.978 \mathrm{E}-02$ & 4.595E-02 & 59.243 \\
\hline Total_Assets(Size) & 265884 & $1.141 \mathrm{E}+01$ & $1.145 \mathrm{E}+01$ & $9.352 \mathrm{E}-01$ & 29565 & $1.408 \mathrm{E}+01$ & $1.377 \mathrm{E}+01$ & $9.218 \mathrm{E}-01$ & -471.61 \\
\hline$R O A$ & 264568 & $2.505 \mathrm{E}-03$ & $3.095 \mathrm{E}-03$ & $4.775 \mathrm{E}-03$ & 29314 & $3.391 \mathrm{E}-03$ & $3.714 \mathrm{E}-03$ & $5.394 \mathrm{E}-03$ & -26.978 \\
\hline Total_Deposits & 264146 & $1.121 \mathrm{E}+01$ & $1.127 \mathrm{E}+01$ & $9.710 \mathrm{E}-01$ & 29294 & $1.369 \mathrm{E}+01$ & $1.350 \mathrm{E}+01$ & $1.072 \mathrm{E}+00$ & -379.4 \\
\hline
\end{tabular}

Notes: The table reports the number of observations, means, medians, standard deviations of main variables by non-TBTF banks and TBTF banks, and t-statistics for mean comparison. The sample period is 2001Q1 to 2010Q4. Appendix C provides all the variable definitions and data sources.

The mean comparison results from Table 3-4 show that the non-deposit funding in non-TBTF banks is significantly lower than in TBTF banks, indicating that small (nonTBTF) banks rely more on deposits as their funding sources than big (TBTF) banks. The results also show that the average uninsured and insured deposit growth rates are higher in non-TBTF banks than in TBTF banks. In particular, the uninsured deposit growth rate in non-TBTF banks is significantly higher.

The higher deposit growth rates in non-TBTF banks can be explained in two ways.

First, non-TBTF banks pay higher interest rates on deposits than TBTF banks, and this

\footnotetext{
${ }^{22}$ We group the banks as TBTF banks and non-TBTF banks after winsorizing. We also replicate the entire analysis by the grouping the banks before winsorizing, the main results are not affected.
} 
would tend to attract deposits. As is evident from Table 3-4, non-TBTF banks present with higher average interest rates on deposits. Second, given that non-TBTF banks exhibit lower $D L L P$, a higher average Tier 1 capital ratio, a lower average non-performing loan ratio, and a lower real estate loan ratio, the fundamentals of non-TBTF banks look favorable compared to TBTF banks. Put another way, the non-TBTF banks appear to be making themselves attractive enough to overcome the possibility that they do not enjoy the same implicit government guarantee that TBTF banks seem to enjoy.

\subsubsection{DLLP and bank performance}

To inform our understanding of whether outsiders consider $D L L P$ a risk factor, we consider whether banks with different degrees of DLLP present with differences in profitability and risk profile.

For each quarter, we rank banks based on their DLLP1. We group banks with $D L L P$ above the 90th percentile to the High_DLLP group (i.e., the opaque group). We group banks below the 10th percentile to the $L o w_{-} D L L P$ group (i.e., the transparent group). The boxplots in Figure 3-1 describe for each period, the two groups' distributions in three performance indicators: (a) banks' profitability (as measured by ROA), (b) profit volatility (as measured by standard deviation of ROA over a moving window of lagged 8 quarters), and (c) banks' loan quality (as measured by non-performing loans scaled by total loans) ) $^{23}$.

\footnotetext{
${ }^{23} \mathrm{We}$ also examined the results by grouping banks based three other $D L L P$ measures (i.e., $D L L P 2, D L L P 3$, and DLLP4), and the results are similar to Figure 3-1.
} 
Figure 3-1 Boxplots of performance indicators between High_DLLP and $L o w \_D L L P$ groups Panel (a): Boxplots of ROA

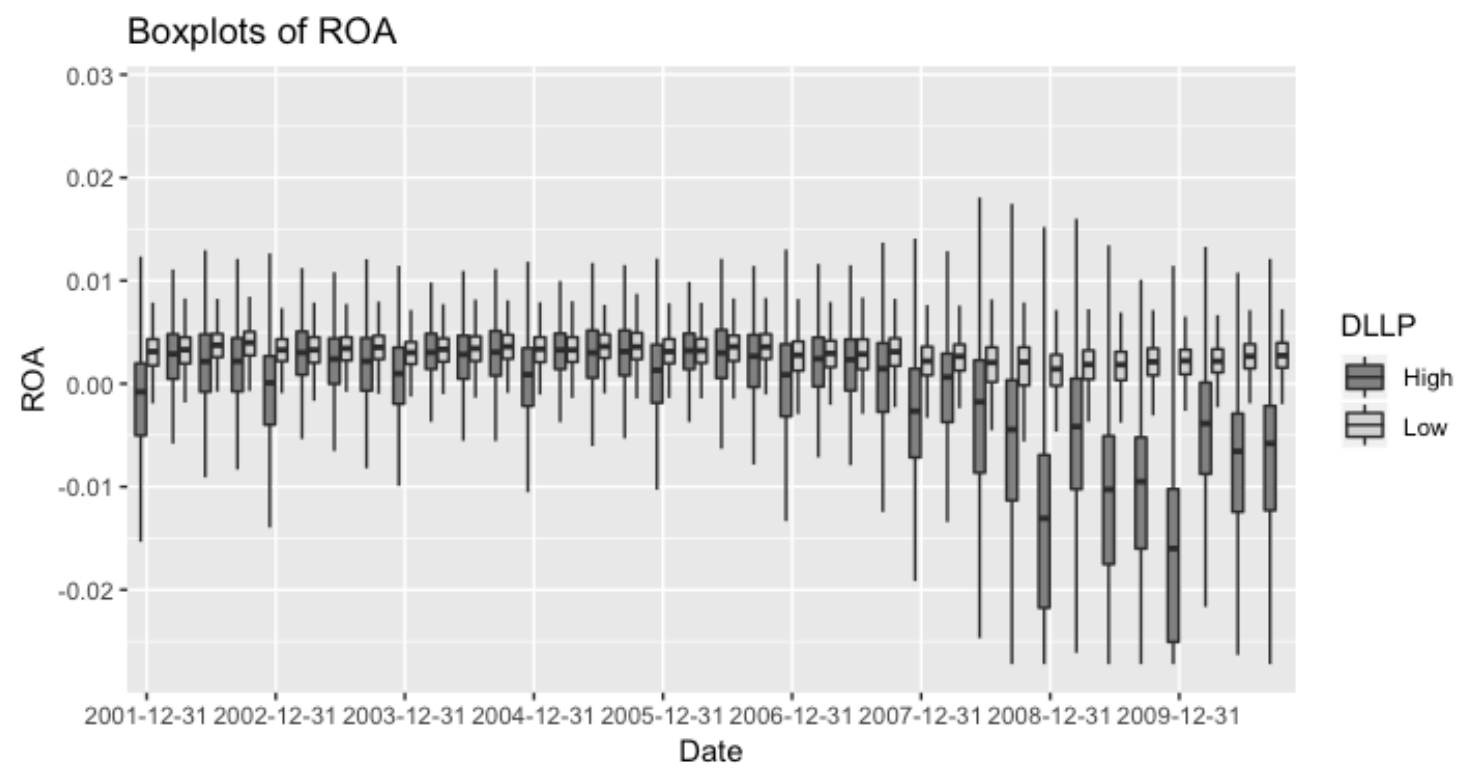

Panel (b): Boxplots of ROA volatility

Boxplots of ROA Volatility

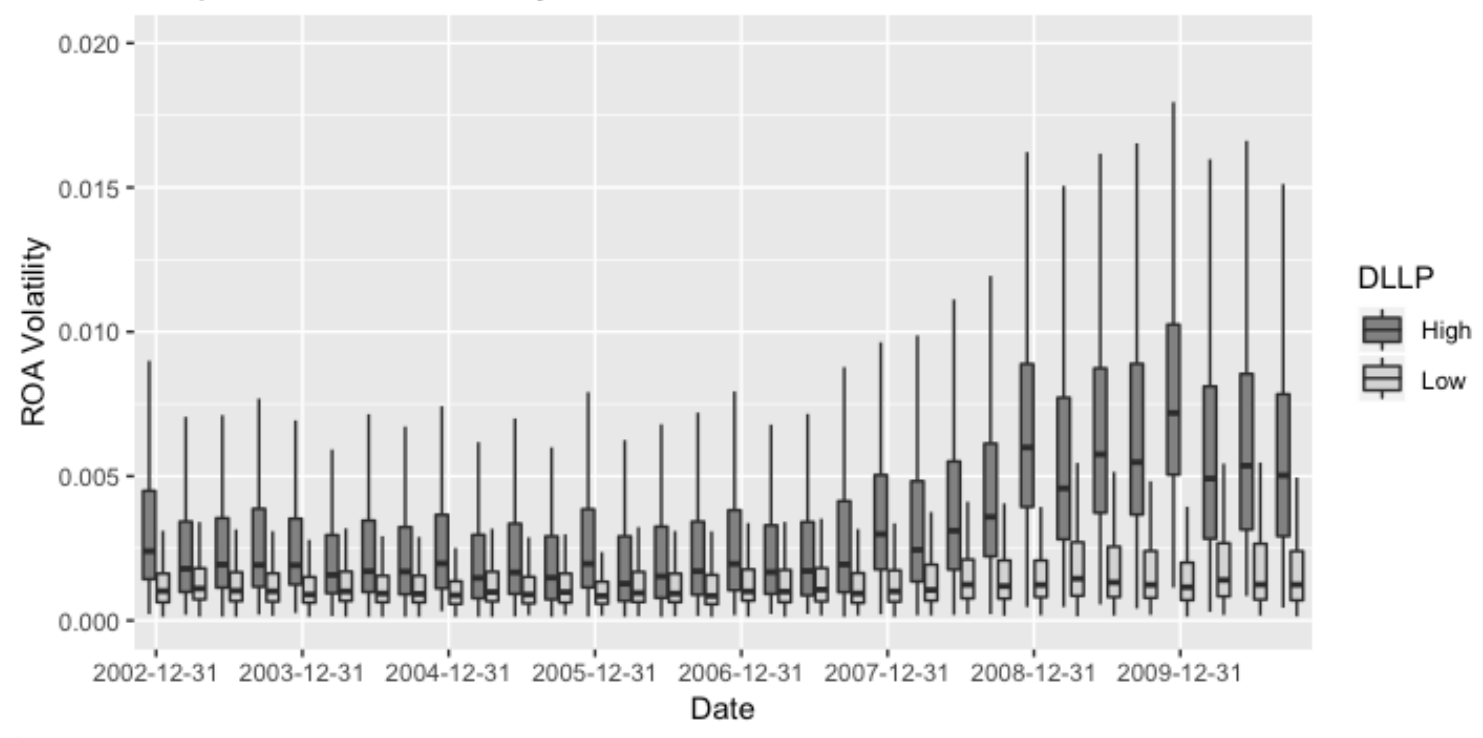




\section{Panel (c): Boxplots of NPA\%}

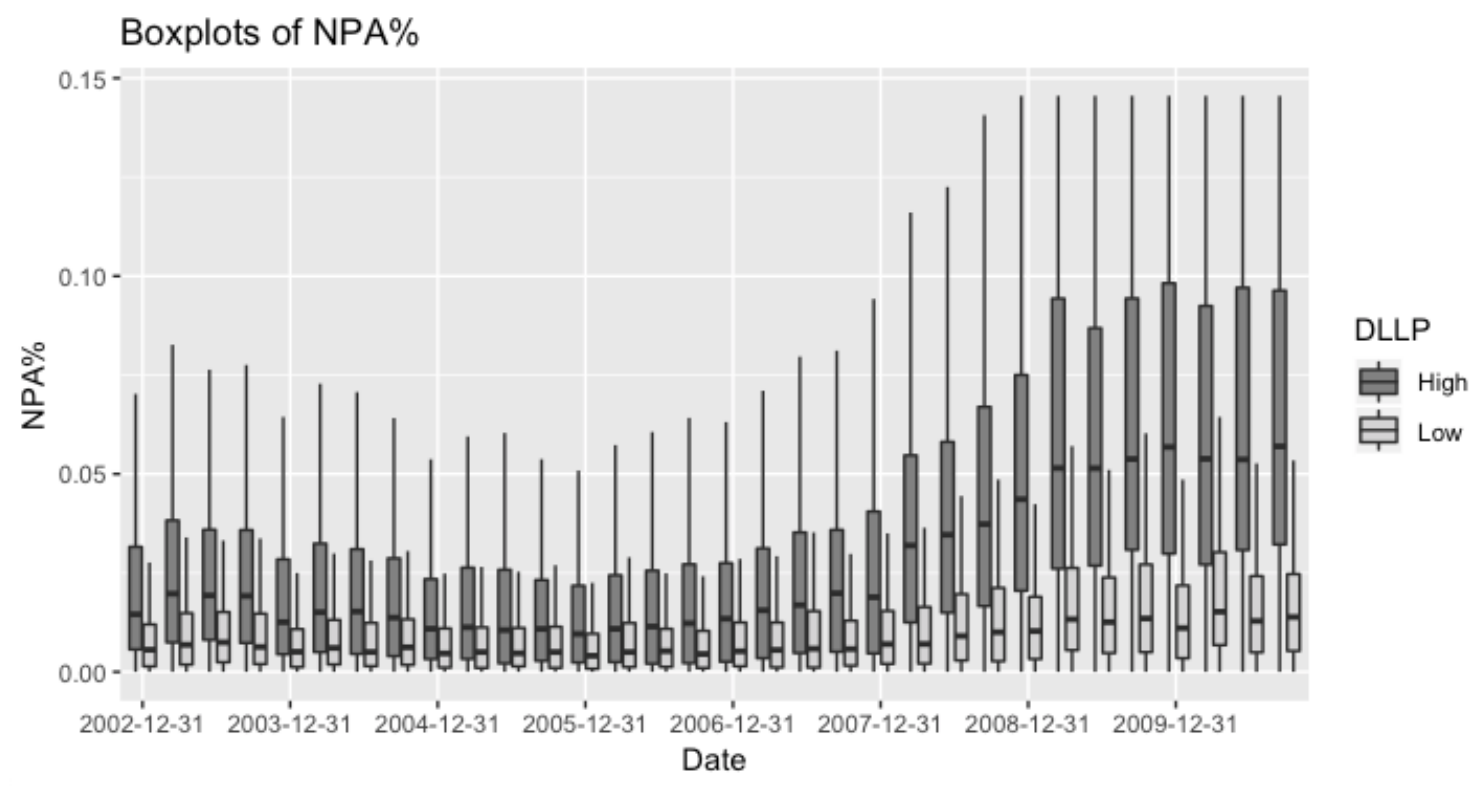

Notes: For each quarter, we rank banks based on their $D L L P 1$. We group banks with $D L L P$ above the 90th percentile to the High_DLLP group (i.e., the opaque group). We group banks below the 10th percentile to the Low_DLLP group (i.e., the transparent group). The boxplots in Figure 3-1 describe for each period, the two groups' distributions in three performance indicators: (a) banks' profitability (as measured by ROA), (b) profit volatility (as measured by standard deviation of ROA over 8 quarters), and (c) banks' loan quality (as measured by non-performing loans scaled by total loans). Within each figure, the boxplots in dark grey describe the distribution of the indicators for the High_DLLP group, and the boxplots in light grey describe the distribution of the indicators for the Low_DLLP group.

We observe several results from the boxplots in Figure 3-1. First, Figure 3-1(a) shows that the ROA of the Low_DLLP group is consistently higher than the ROA of the High_DLLP group over time. Second, Figure 3-1(b) shows that the volatility in ROA of the $L o w_{-} D L L P$ group is consistently lower than the volatility in ROA of the High_DLLP group over time. Third, Figure 3-1(c) shows that the NPA\% (i.e., the non-performing loan ratio) of the High_DLLP group is consistently higher than the NPA\% of the Low DLLP group. Additionally, from Figure 3-1, we can observe that the difference in each indicator between the two groups is increasing during the 2008 crisis period.

The conclusion from Figure 3-1 is that banks with a high degree of DLLP are associated with poor performance on the measures shown compared to the banks with a 
low degree of $D L L P$. During the market downturn, the performance of High_DLLP on the NPA\% is even worse. As a result, the High_DLLP banks can hardly mask their deteriorating asset quality during the crisis period.

\subsubsection{Baseline regression results}

Table 3-5 provides the baseline regression results using the whole sample period: 2001Q1 to 2010Q4. ${ }^{24}$ Columns (1) to (3) report the OLS regression results of model (5). Columns (4) to (6) report the OLS regression results of model (6). Columns (7) to (9) report the OLS regression results of model (7). We report the results separately for all banks, for non-TBTF banks, and for TBTF banks. The DLLP measure used is DLLPI based on LLP model (1).

\footnotetext{
${ }^{24}$ For each of the baseline regression, we perform the Breusch-Pagan Lagrange Multiplier Test to examine residuals' heteroskedasticity. The Breusch-Pagan Test result suggests the presence of heteroskedasticity in model (5) - (7). To address the heteroskedasticity problem, in the unreported additional regressions, we obtain the heteroskedasticity-consistent coefficient estimates via the method proposed by White (1984). The significance of the adjusted coefficients for $D L L P$ is not significantly affected. We also perform the DurbinWatson Test to examine serial correlation in residuals. The Durbin-Watson Test result shows that, for each of the model in (5) - (7), we cannot reject the null hypothesis that there is no serial correlation in idiosyncratic errors. So we don't have the problem of serial correlation in errors. In addition, to address the concern for multicollinearity, we calculate the Variance Inflation Factors (VIFs). We find no evidence of the presence of a multicollinearity problem.
} 
Table 3-5 The baseline regression results

\begin{tabular}{|c|c|c|c|c|c|c|c|c|c|}
\hline \multirow[t]{2}{*}{ Dependent Variable: } & \multicolumn{3}{|c|}{ Uninsured_Deposit_Growth_Rate $e_{i, t}$} & \multicolumn{3}{|c|}{ Insured_Deposit_Growth_Rate $_{i, t}$} & \multicolumn{3}{|c|}{ Interest expenses $\%_{i, t}$} \\
\hline & $\begin{array}{l}\text { All Banks } \\
\text { (1) }\end{array}$ & $\begin{array}{l}\text { non-TBTF Banks } \\
\text { (2) }\end{array}$ & $\begin{array}{l}\text { TBTF Banks } \\
\text { (3) }\end{array}$ & $\begin{array}{l}\text { All Banks } \\
\text { (4) }\end{array}$ & $\begin{array}{l}\text { non-TBTF Banks } \\
\text { (5) }\end{array}$ & $\begin{array}{l}\text { TBTF Banks } \\
\text { (6) }\end{array}$ & $\begin{array}{l}\text { All Banks } \\
\text { (7) }\end{array}$ & $\begin{array}{l}\text { non-TBTF Banks } \\
\text { (8) }\end{array}$ & $\begin{array}{l}\text { TBTF Banks } \\
\text { (9) }\end{array}$ \\
\hline (Intercept) & $0.744 * * *(21.329)$ & $0.938 * * *(24.557)$ & $0.081(0.898)$ & $-0.031 * * *(-4.812)$ & $-0.029 * * *(-4.418)$ & $0.024(0.802)$ & $0.001 * * *(10.854)$ & $0.001 * * *(7.987)$ & $0.000(0.038)$ \\
\hline$D L L P 1_{i, t-1}$ & $-2.382 * * *(-6.038)$ & $-2.699 * * *(-6.100)$ & $-1.153(-1.611)$ & $-1.238 * * *(-17.259)$ & $-1.610 * * *(-21.038)$ & $-0.447 *(-1.896)$ & $0.023 * * *(17.850)$ & $0.009 * * *(6.014)$ & $0.060 * * *(15.532)$ \\
\hline $\operatorname{TIER} 1_{i, t-1}$ & $0.223 * * *(10.119)$ & $0.199 * * *(8.271)$ & $0.259 * * *(4.857)$ & $0.276 * * *(68.956)$ & $0.286 * * *(68.975)$ & $0.101 * * *(5.818)$ & $0.000 * * *(4.168)$ & $0.000(-0.315)$ & $0.004 * * *(12.804)$ \\
\hline$N P A_{i, t-1}$ & $-0.744 * * *(-14.653)$ & $-0.742 * * *(-13.668)$ & $-0.827 * * *(-6.558)$ & $-0.486 * * *(-52.114)$ & $-0.510 * * *(-54.000)$ & $-0.097 * *(-2.269)$ & $0.007 * * *(41.858)$ & $0.006 * * *(37.132)$ & $0.015 * * *(21.731)$ \\
\hline RealEstate $\%_{i, t-1}$ & $-0.006(-1.230)$ & $0.012 * *(2.193)$ & $-0.028 * *(-2.418)$ & $0.009 * * *(9.944)$ & $0.012 * * *(12.854)$ & $-0.021 * * *(-5.542)$ & $0.000 * * *(30.117)$ & $0.001 * * *(29.745)$ & $0.000 * * *(6.278)$ \\
\hline Non_Interest_Income $e_{t-1}$ & $0.060 * * *(5.843)$ & $0.066 * * *(5.769)$ & $0.026(1.356)$ & $0.025 * * *(13.304)$ & $0.024 * * *(12.040)$ & $0.024 * * *(3.758)$ & $-0.004 * * *(-116.509)$ & $-0.004 * * *(-115.767)$ & $-0.002 * * *(-21.782)$ \\
\hline Non_Deposit_Funding $g_{t-1}$ & $0.278 * * *(17.216)$ & $0.344 * * *(14.213)$ & $0.128 * * *(5.552)$ & $0.055 * * *(18.648)$ & $0.073 * * *(17.581)$ & $0.042 * * *(5.365)$ & $0.001 * * *(20.711)$ & $0.001 * * *(17.724)$ & $0.001 * * *(8.085)$ \\
\hline Liquidity_Ratio $_{i, t-1}$ & $-0.101 * * *(-6.149)$ & $-0.130 * * *(-7.493)$ & $-0.054(-1.046)$ & $-0.053 * * *(-17.547)$ & $-0.054 * * *(-17.927)$ & $-0.047 * * *(-2.688)$ & $-0.005 * * *(-87.887)$ & $-0.005 * * *(-84.787)$ & $-0.006 * * *(-19.917)$ \\
\hline Interest_Expenses $\%_{i, t-1}$ & $6.622 * * *(11.098)$ & $7.344 * * *(11.271)$ & $3.125 * *(2.511)$ & $2.375 * * *(21.766)$ & $2.379 * * *(21.045)$ & $0.899 * *(2.179)$ & & & \\
\hline Size $_{i, t-1}$ & $-0.052 * * *(-10.532)$ & $-0.106 * * *(-9.072)$ & $-0.020 * * *(-3.939)$ & $-0.003 * * *(-3.560)$ & $-0.016 * * *(-7.845)$ & $-0.004 * *(-2.194)$ & $0.000 * * *(-3.248)$ & $0.000 * * *(-4.264)$ & $0.000 * *(-2.113)$ \\
\hline$R O A_{i, t-1}$ & $-2.765 * * *(-9.926)$ & $-2.977 * * *(-9.587)$ & $0.316(0.584)$ & $-2.926 * * *(-57.709)$ & $-3.367 * * *(-62.706)$ & $0.141(0.781)$ & $-0.020 * * *(-21.381)$ & $-0.029 * * *(-28.895)$ & $-0.005(-1.521)$ \\
\hline Total_Deposits $_{i, t-1}$ & $0.017 * * *(3.555)$ & $0.057 * * *(4.947)$ & $0.004(1.013)$ & $0.004 * * *(5.133)$ & $0.017 * * *(8.481)$ & $0.001(0.758)$ & $0.000 * * *(6.312)$ & $0.000 * * *(6.517)$ & $0.000 * * *(4.994)$ \\
\hline Tbill_3 $3 M_{t-1}$ & $-7.510 * * *(-18.652)$ & $-8.413 * * *(-19.398)$ & $-2.620 * * *(-2.822)$ & $-0.314 * * *(-4.241)$ & $-0.338 * * *(-4.483)$ & $0.333(1.064)$ & $0.207 * * *(164.818)$ & $0.209 * * *(163.041)$ & $0.199 * * *(40.530)$ \\
\hline$T 10 Y 3 M_{t-1}$ & $-0.075 * * *(-9.175)$ & $-0.084 * * *(-9.670)$ & $0.024(1.255)$ & $-0.002(-1.324)$ & $-0.003 *(-1.671)$ & $0.004(0.667)$ & $0.000 * * *(14.539)$ & $0.000 * * *(14.158)$ & $0.000 * * *(3.850)$ \\
\hline Ted_Rate $_{t-1}$ & $-0.096 *(-1.723)$ & $-0.146 * *(-2.443)$ & $0.476 * * *(3.606)$ & $0.008(0.786)$ & $0.011(1.081)$ & $-0.008(-0.169)$ & $-0.001 * * *(-5.542)$ & $-0.001 * * *(-5.101)$ & $-0.001 * *(-2.011)$ \\
\hline Quarter fixed effect & Yes & Yes & Yes & Yes & Yes & Yes & Yes & Yes & Yes \\
\hline No. of obs. & 245946 & 224700 & 21246 & 246514 & 225163 & 21351 & 247003 & 225614 & 21389 \\
\hline Adj. R-Squared & 0.019 & 0.021 & 0.021 & 0.066 & 0.076 & 0.031 & 0.550 & 0.558 & 0.540 \\
\hline
\end{tabular}

Notes: The table provides the baseline regression results using the whole sample period (2001Q1 to 2010Q4). Appendix C provides all the variable definitions and data sources. Columns (1) - (3) report the OLS regression results for model (5), which uses Uninsured_Deposit_Growth_Rate as the dependent variable. Column (4) - (6) report the OLS regression results for model (6), which uses Insured_Deposit_Growth_Rate as the dependent variable. Column (7) - (9) report the OLS regression results for model (7), which uses Interest expenses\% as the dependent variable. Each column reports the coefficient estimates and t-statistics (in parentheses). The results are reported by all banks, non-TBTF banks, and TBTF banks. The explanatory variable DLLP1 is computed based on Equation (1). $* * *, * *$, and $*$ represent $1 \%, 5 \%$, and $10 \%$ significance, respectively. 
First, column (1) reports that $D L L P 1_{i, t-1}$ obtains a negative coefficient of -2.382 , which is significant at $1 \%$. Thus, consistent with Hypothesis $1, D L L P 1_{i, t-1}$ is significantly negatively related to Uninsured_Deposit_Growth_Rate ${ }_{i, t}$, indicating that banks with high $D L L P$ (i.e., opaque banks) are associated with lower uninsured deposit growth rate. In terms of other risk factors, banks with a higher Tier-1 capital ratio, with a lower nonperforming loan ratio, and with a lower real estate loan ratio are associated with a higher uninsured deposit growth rate. These results suggest that uninsured depositors consider $D L L P$ as a risk factor and they punish riskier banks with a smaller supply of uninsured deposits.

Next, we examine the results by bank size groups. Column (2) shows that within the non-TBTF banks, the coefficient of $D L L P 1_{i, t-1}$ is -2.699 , which is also significant at 1\%. However, from Column (3), we see that within the TBTF banks, although the coefficient of $D L L P 1_{i, t-1}$ is negative, it is not statistically significant. The findings from Columns (2) and (3) are consistent with Hypothesis 2, showing that the negative relationship between $D L L P 1_{i, t-1}$ and Uninsured_Deposit_Growth_Rate $i, t$ is mainly driven by the non-TBTF banks. The market discipline from uninsured deposit growth rates is much weaker for TBTF banks than for non-TBTF banks.

The regression results for model (6) are similar. Columns (4) to (6) show that $D L L P 1_{i, t-1}$ is significantly, negatively related to the Insured_Deposit_Growth_Rate ${ }_{i, t}$, and the negative effect is larger and more significant within the non-TBTF banks. This finding suggests that insured depositors react to non-TBTF banks' $D L L P$ practices.

The regression results for model (7) suggest that banks with high $D L L P 1_{i, t-1}$ are associated with high Interest_Expenses $\%_{i, t}$. The result is consistent with the idea that 
depositors demand higher interest rates from opaque banks. However, the coefficient for $D L L P 1_{i, t-1}$ on Interest_Expenses $\%_{i, t}$ is both positive and significant for both the non-TBTF and the TBTF banks, implying that for the TBTF banks, market discipline is not operating to reduce deposit supply, but appears to be working through higher deposit interest rates.

One potential issue in measuring depositors' reactions to $D L L P$ is that, in addition to reacting to $D L L P$ practices in the immediately preceding quarter, depositors may also react to the recent history of $D L L P$ practices over several quarters. This is because the recent history of $D L L P$ practices may reflect an underlying policy to manage earnings (Hutton, Marcus, and Tehranian, 2009).

To measure accumulated $D L L P(A D L L P)$ practices, we define bank $i$ 's $A D L L P_{i, t}$ at quarter $t$ as the sum of DLLPs in quarter $t, t-1, t-2$, and $t-3$ :

$$
A D L L P_{t, i}=D L L P_{t, i}+D L L P_{t-1, i}+D L L P_{t-2, i}+D L L P_{t-3, i}
$$

Recall that $D L L P$ is measured as the absolute value of the residuals from estimating a LLP model, $A D L L P$ is the sum of absolute values of the residuals. A high $A D L L P$ can therefore result from both positive and negative abnormal accruals.

We re-estimate the regression models (5) to (7) replacing DLLP1 with ADLLP1. We report the results in Table 3-6. We find that the results of using $A D L L P 1$ are very close to the results of using DLLP1 as the predictor. This finding suggests that the depositors react to the single-period $D L L P$ and multiple-period $D L L P$ in a similar way. 
Table 3-6 Using the $A D L L P 1$ measure for the baseline regression

\begin{tabular}{|c|c|c|c|c|c|c|c|c|c|}
\hline \multirow[t]{2}{*}{ Dependent Variable: } & \multicolumn{3}{|c|}{ Uninsured_Deposit_Growth_Rate ${ }_{i, t}$} & \multicolumn{3}{|c|}{ Insured_Deposit_Growth_Rate $e_{i, t}$} & \multicolumn{3}{|l|}{ Interest expenses $\%_{i, t}$} \\
\hline & $\begin{array}{l}\text { All Banks } \\
\text { (1) }\end{array}$ & $\begin{array}{l}\text { non-TBTF Banks } \\
\text { (2) }\end{array}$ & $\begin{array}{l}\text { TBTF Banks } \\
\text { (3) }\end{array}$ & $\begin{array}{l}\text { All Banks } \\
\text { (4) }\end{array}$ & $\begin{array}{l}\text { non-TBTF Banks } \\
\text { (5) }\end{array}$ & $\begin{array}{l}\text { TBTF Banks } \\
\text { (6) }\end{array}$ & $\begin{array}{l}\text { All Banks } \\
\text { (7) }\end{array}$ & $\begin{array}{l}\text { non-TBTF Banks } \\
(8)\end{array}$ & $\begin{array}{l}\text { TBTF Banks } \\
\text { (9) }\end{array}$ \\
\hline (Intercept) & $0.765 * * *(21.234)$ & $0.949 * * *(24.166)$ & $0.040(0.407)$ & $-0.018 * * *(-2.884)$ & $-0.011 *(-1.797)$ & $-0.003(-0.101)$ & $0.001 * * *(8.353)$ & $0.001 * * *(5.742)$ & $-0.001(-1.360)$ \\
\hline$A D L L P 1_{i, t-1}$ & $-0.550 * * *(-3.551)$ & $-0.735 * * *(-4.121)$ & $-0.256(-1.002)$ & $-0.242 * * *(-9.164)$ & $-0.297 * * *(-10.327)$ & $-0.435 * * *(-5.107)$ & $0.017 * * *(33.283)$ & $0.012 * * *(21.898)$ & $0.023 * * *(17.138)$ \\
\hline $\operatorname{TIER} 1_{i, t-1}$ & $0.142 * * *(5.584)$ & $0.125^{* * *}(4.524)$ & $0.214^{* * *}(3.610)$ & $0.118 * * *(27.244)$ & $0.117^{* * *}(26.295)$ & $0.108^{* * *}(5.523)$ & $0.000(0.338)$ & $0.000 * * *(-3.691)$ & $0.004 * * *(11.605)$ \\
\hline$N P A_{i, t-1}$ & $-0.614 * * *(-10.819)$ & $-0.594 * * *(-9.785)$ & $-0.753 * * *(-5.330)$ & $-0.340 * * *(-34.628)$ & $-0.359 * * *(-36.406)$ & $0.006(0.131)$ & $0.005 * * *(27.762)$ & $0.005 * * *(25.754)$ & $0.013 * * *(16.322)$ \\
\hline RealEstate $\%_{i, t-1}$ & $-0.019 * * *(-3.675)$ & $-0.002(-0.423)$ & $-0.034 * * *(-2.636)$ & $0.001(1.509)$ & $0.004 * * *(4.722)$ & $-0.024 * * *(-5.557)$ & $0.001 * * *(29.570)$ & $0.001 * * *(28.566)$ & $0.000 * * *(6.947)$ \\
\hline Non_Interest_Income $e_{t-1}$ & $0.050 * * *(4.573)$ & $0.055 * * *(4.490)$ & $0.032(1.563)$ & $0.020 * * *(10.517)$ & $0.016^{* * *}(8.118)$ & $0.031 * * *(4.444)$ & $-0.004 * * *(-110.363)$ & $-0.004 * * *(-109.937)$ & $-0.002 * * *(-19.304)$ \\
\hline Non_Deposit_Funding $g_{t-1}$ & $0.270 * * *(15.631)$ & $0.325 * * *(12.550)$ & $0.138 * * *(5.405)$ & $0.054 * * *(18.193)$ & $0.060 * * *(14.526)$ & $0.039 * * *(4.440)$ & $0.001 * * *(19.503)$ & $0.001 * * *(15.354)$ & $0.001 * * *(7.367)$ \\
\hline Liquidity_Ratio $_{i, t-1}$ & $-0.092 * * *(-5.264)$ & $-0.119 * * *(-6.474)$ & $-0.052(-0.946)$ & $-0.033 * * *(-10.777)$ & $-0.032 * * *(-10.823)$ & $-0.055 * * *(-2.916)$ & $-0.005 * * *(-83.038)$ & $-0.005 * * *(-79.857)$ & $-0.006 * * *(-18.403)$ \\
\hline Interest_Expenses $\%_{i, t-1}$ & $6.711 * * *(10.345)$ & $7.422 * * *(10.529)$ & $3.231 * *(2.309)$ & $2.775 * * *(24.776)$ & $2.762 * * *(24.159)$ & $1.492 * * *(3.182)$ & & & \\
\hline Size $_{i, t-1}$ & $-0.050 * * *(-9.472)$ & $-0.099 * * *(-7.741)$ & $-0.020 * * *(-3.665)$ & $-0.001(-0.924)$ & $-0.005 * *(-2.562)$ & $-0.001(-0.412)$ & $0.000 *(-1.679)$ & $0.000 *(-1.672)$ & $0.000(-0.239)$ \\
\hline$R O A_{i, t-1}$ & $-1.032 * * *(-3.697)$ & $-1.189 * * *(-3.854)$ & $0.898(1.574)$ & $-1.219 * * *(-25.344)$ & $-1.447 * * *(-28.986)$ & $0.295(1.525)$ & $-0.018 * * *(-19.444)$ & $-0.023 * * *(-23.472)$ & $-0.015 * * *(-4.832)$ \\
\hline Total_Deposits $_{i, t-1}$ & $0.015 * * *(2.918)$ & $0.050 * * *(3.980)$ & $0.005(1.101)$ & $0.002 * *(2.214)$ & $0.006 * * *(2.901)$ & $0.000(0.056)$ & $0.000 * * *(6.027)$ & $0.000 * * *(4.377)$ & $0.000 * * *(4.553)$ \\
\hline Tbill_ $3 M_{t-1}$ & $-6.252 * * *(-10.217)$ & $-7.294 * * *(-11.159)$ & $1.028(0.687)$ & $0.126(1.185)$ & $0.111(1.047)$ & $0.632(1.233)$ & $0.172 * * *(86.041)$ & $0.174 * * *(85.174)$ & $0.173 * * *(21.371)$ \\
\hline$T 10 Y 3 M_{t-1}$ & $-0.075 * * *(-9.007)$ & $-0.084 * * *(-9.523)$ & $0.032(1.558)$ & $-0.002(-1.204)$ & $-0.002(-1.568)$ & $0.005(0.731)$ & $0.000 * * *(13.749)$ & $0.000 * * *(13.531)$ & $0.000 * * *(3.574)$ \\
\hline Ted_Rate $_{t-1}$ & 0.186456 & $-0.153 * * *(-2.582)$ & $0.522 * * *(3.768)$ & $0.008(0.792)$ & $0.010(1.054)$ & $-0.015(-0.312)$ & $-0.001 * * *(-4.777)$ & $-0.001 * * *(-4.533)$ & 0.001679 \\
\hline Quarter fixed effect & Yes & Yes & Yes & Yes & Yes & Yes & Yes & Yes & Yes \\
\hline No. of obs. & 217203 & 199257 & 17946 & 217704 & 199662 & 18042 & 218142 & 200063 & 18079 \\
\hline Adj. R-Squared & 0.019 & 0.02 & 0.022 & 0.031 & 0.034 & 0.033 & 0.566 & 0.572 & 0.567 \\
\hline
\end{tabular}

Notes: The table provides the baseline regression results using the whole sample period (2001Q1 to 2010Q4). The explanatory variable $A D L L P 1$ is computed based on equation (8). Appendix C provides all the variable definitions and data sources. Columns (1) - (3) report the OLS regression results for model (5), which uses Uninsured_Deposit_Growth_Rate as the dependent variable. Column (4) - (6) report the OLS regression results for model (6), which uses Insured_Deposit_Growth_Rate as the dependent variable. Column (7) - (9) report the OLS regression results for model (7), which uses Interest expenses\% as the dependent variable. Each column reports the coefficient estimates and t-statistics (in parentheses). The results are reported by all banks, non-TBTF banks, and TBTF banks.

$* * *, * *$, and $*$ represent $1 \%, 5 \%$, and $10 \%$ significance, respectively. 


\subsubsection{Robustness checks}

\subsubsection{The impact of the financial crisis}

There is the possibility that market discipline might have been different during the 2008-2009 crisis period. For example, Berger and Turk-Ariss (2015) find that during the 2008-2009 crisis period, uninsured depositors were no longer sensitive to large U.S. banks' risk-taking behavior. Beyhaghi, D'Souza, and Roberts (2014) also find that during the crisis period, Canadian banks' funding costs were not sensitive to the banks' risk factors, especially for deposits. So, it is possible that, during the crisis period, market discipline changed when the market perceived an elevated propensity for the government to step in to help the big banks.

We consider the possibility that depositors punish the large banks less, or not at all, with the expected government intervention. It is also possible that for the small banks without government guarantees, market discipline may increase during the crisis period because of the increasing awareness of bank failures. To examine these matters, we estimate equation (5) separately using two sub-period samples: pre-crisis period (2000Q12007Q4) and crisis period (2008Q1-2009Q3). Table 3-7 reports the results. 
Table 3-7 The sub-period regression results

\begin{tabular}{|c|c|c|c|c|c|c|}
\hline \multirow[t]{3}{*}{ Dependent Variable: } & \multicolumn{6}{|c|}{ Uninsured_Deposit_Growth_Rate $e_{i, t}$} \\
\hline & \multicolumn{3}{|c|}{ Pre-crisis period (2001Q1-2007Q4) } & \multicolumn{3}{|c|}{ Crisis period (2008Q1-2009Q3) } \\
\hline & $\begin{array}{l}\text { All Banks } \\
\text { (1) }\end{array}$ & $\begin{array}{l}\text { non-TBTF Banks } \\
\text { (2) }\end{array}$ & $\begin{array}{l}\text { TBTF Banks } \\
\text { (3) }\end{array}$ & $\begin{array}{l}\text { All Banks } \\
\text { (4) }\end{array}$ & $\begin{array}{l}\text { non-TBTF Banks } \\
\text { (5) }\end{array}$ & $\begin{array}{l}\text { TBTF Banks } \\
\text { (6) }\end{array}$ \\
\hline (Intercept) & $0.449 * *(2.281)$ & $0.543 * *(2.562)$ & $0.592(1.413)$ & $0.040(0.988)$ & $0.153 * * *(3.351)$ & $-0.029(-0.193)$ \\
\hline$D L L P 1_{i, t-1}$ & $-1.741 * * *(-3.390)$ & $-1.826 * * *(-3.141)$ & $-3.617 * * *(-4.187)$ & $-3.071 * * *(-4.127)$ & $-3.697 * * *(-4.481)$ & $-0.483(-0.318)$ \\
\hline TIER $1_{i, t-1}$ & $0.198 * * *(8.185)$ & $0.173 * * *(6.522)$ & $0.212 * * *(4.170)$ & $0.366 * * *(8.521)$ & $0.310 * * *(6.729)$ & $0.682 * * *(5.408)$ \\
\hline$N P A_{i, t-1}$ & $-0.681 * * *(-9.502)$ & $-0.679 * * *(-8.986)$ & $-1.082 * * *(-5.248)$ & $-0.700 * * *(-7.505)$ & $-0.732 * * *(-7.314)$ & $-0.514 * *(-2.186)$ \\
\hline RealEstate $\%_{i, t-1}$ & $0.011 * *(2.067)$ & $0.026 * * *(4.492)$ & $-0.010(-0.858)$ & $-0.019 *(-1.741)$ & $-0.002(-0.168)$ & $-0.061 * *(-2.090)$ \\
\hline Non_Interest_Income $e_{t-1}$ & $0.071 * * *(6.294)$ & $0.078 * * *(6.116)$ & $0.024(1.256)$ & $0.059 * * *(2.582)$ & $0.053 * *(2.093)$ & $0.081 *(1.740)$ \\
\hline Non_Deposit_Funding $g_{t-1}$ & $0.241 * * *(13.700)$ & $0.270 * * *(10.320)$ & $0.126 * * *(5.756)$ & $0.366 * * *(11.092)$ & $0.456 * * *(9.195)$ & $0.180 * * *(3.037)$ \\
\hline Liquidity_Ratio $_{i, t-1}$ & $-0.111 * * *(-5.677)$ & $-0.136 * * *(-6.579)$ & $-0.071(-1.242)$ & $-0.039(-1.093)$ & $-0.071 *(-1.886)$ & $0.125(0.957)$ \\
\hline Interest_Expenses $\%_{i, t-1}$ & $6.339 * * *(9.874)$ & $7.409 * * *(10.517)$ & $1.566(1.269)$ & $8.148 * * *(6.909)$ & $8.037 * * *(6.323)$ & $8.197 * * *(2.872)$ \\
\hline Size $_{i, t-1}$ & $-0.046 * * *(-8.392)$ & $-0.077 * * *(-6.204)$ & $-0.020 * * *(-4.013)$ & $-0.060 * * *(-6.224)$ & $-0.113 * * *(-4.744)$ & $-0.034 * * *(-2.939)$ \\
\hline$R O A_{i, t-1}$ & $-3.099 * * *(-9.455)$ & $-3.383 * * *(-9.232)$ & $1.622 * * *(2.656)$ & $-3.585 * * *(-7.200)$ & $-3.945 * * *(-7.170)$ & $-0.518(-0.476)$ \\
\hline Total_Deposits $s_{i, t-1}$ & $0.013 * *(2.512)$ & $0.032 * * *(2.628)$ & $0.005(1.133)$ & $0.031 * * *(3.324)$ & $0.074 * * *(3.115)$ & $0.017 *(1.790)$ \\
\hline Tbill_3 $M_{t-1}$ & $-3.038(-0.712)$ & $-2.393(-0.521)$ & $-8.842(-0.977)$ & $5.102 * * *(7.059)$ & $5.245 * * *(6.838)$ & $2.902(1.474)$ \\
\hline$T 10 Y 3 M_{t-1}$ & $-0.022(-0.544)$ & $-0.017(-0.390)$ & $-0.075(-0.867)$ & $0.106 * * *(9.107)$ & $0.107 * * *(8.721)$ & $0.081 * * *(2.581)$ \\
\hline Ted_Rate $_{t-1}$ & $0.053 * * *(6.777)$ & $0.057 * * *(6.858)$ & $0.017(1.008)$ & $-0.021 * * *(-4.089)$ & $-0.023 * * *(-4.115)$ & $-0.002(-0.108)$ \\
\hline Quarter fixed effect & Yes & Yes & Yes & Yes & Yes & Yes \\
\hline No. of obs. & 173647 & 158416 & 15231 & 40117 & 36801 & 3316 \\
\hline Adj. R-Squared & 0.016 & 0.017 & 0.020 & 0.028 & 0.029 & 0.029 \\
\hline
\end{tabular}

Notes: The table provides the OLS regression results of estimating model (5) for the pre-crisis sample period (2001Q1 to 2007Q4) and for the crisis period (2008Q1 to 2009Q3). Appendix C provides all the variable definitions and data sources. Each column reports the coefficient estimates and t-statistics (in parentheses). The results are reported for all banks, non-TBTF banks, and TBTF banks. $* * *, * *$, and $*$ represent $1 \%, 5 \%$, and $10 \%$ significance, respectively. 
The results in Table 3-7 columns (1) to (3) show that, during the pre-crisis period, the coefficient on $D L L P 1_{i, t-1}$ is negative and significant for both non-TBTF and TBTF banks, indicating that uninsured deposit growth rates react sensitively to $D L L P$ for both groups of banks before the crisis period. Columns (4) to (6) report the crisis period results. We see that, although the coefficient on $D L L P 1_{i, t-1}$ is negative for both non-TBTF and TBTF banks, the coefficient is significant only for the non-TBTF banks, indicating that the uninsured deposit growth rate loses its sensitivity to risk, as proxied by $D L L P I$, during the crisis period.

In addition, comparing the pre-crisis and crisis period results for the non-TBTF banks, we find that the coefficient on $D L L P 1_{i, t-1}$ becomes more negative (with coefficient values changing from -1.826 in the pre-crisis period to -3.697 in the crisis period) and more significant (with the t-statistics changing from -3.141 in the pre-crisis period to -4.481 in the crisis period). These results suggest that, during the non-crisis period, both large and small banks were punished similarly for their $D L L P$ practices. But during the crisis period, market discipline for the TBTF banks appears to be much weaker than for the non-TBTF banks, a result that is consistent with a belief in an implicit government guarantee of the TBTF banks. The results are consistent with the findings from Berger and Turk-Ariss (2014). They find that during the 2008-2009 crisis period, the depositor discipline decreased for the large U.S. banks, but not for the small U.S. banks.

\subsubsection{The impact from government bailout actions during the crisis}

In our prior analysis, we used bank asset size to indicate the possible existence of implicit government guarantees. In the financial crisis, however, the government took explicit bailout actions to save banks, some of which were not among the largest banks. 
These actions may have also affected how market discipline was applied differentially to the banks that were helped as compared to the banks that were not helped. Thus, we examine during the post-government bailout period (i.e., 2008Q4 to 2010Q4) whether market discipline is different for the bailed-out banks versus non-bailed-out banks. The specific bailout action we focus on is the Troubled Asset Relief Program (TARP), which is the largest of the U.S. government bailout actions following the financial crisis.

TARP was initiated on October 14, 2008 by the U.S. Treasury Department to bail out troubled U.S. banks. The first round of TARP infusion was mandatory and was undertaken with 9 of the largest U.S. banks. The second round of TARP infusion was optional. 705 financial institutions applied for the program. Applicants were assessed and those that were judged to be financially sound were selected for participation. We consider the possibility that banks supported by TARP would be considered safer than other banks with the result that depositors of those banks would react less sensitively to their riskiness after the TARP fund injection.

We obtained government TARP program information from the U.S. Treasury website. If a bank's name or a bank's parent bank holding company's name in our data set matches the recipient bank name listed in the TARP program, we mark the bank as a TARP fund recipient. We group the TARP recipients as TARP banks and the others as non-TARP banks. Next, we estimate equation (5) for the TARP bank group and non-TARP bank group separately for the post-TARP period (2008Q4 to 2010Q4). Table 3-8 reports the regression results. 
Table 3-8 The TARP effect

\begin{tabular}{|c|c|c|c|}
\hline & $\begin{array}{l}\text { All Banks } \\
\text { (1) }\end{array}$ & $\begin{array}{l}\text { Non-TARP Banks } \\
(2)\end{array}$ & $\begin{array}{l}\text { TARP Banks } \\
\text { (3) }\end{array}$ \\
\hline (Intercept) & $0.884 * * *(18.396)$ & $0.870 * * *(16.817)$ & $0.979 * * *(7.476)$ \\
\hline$D L L P 1_{i, t-1}$ & $-2.976 * * *(-3.526)$ & $-2.869 * * *(-3.170)$ & $-4.529 *(-1.896)$ \\
\hline $\operatorname{TIER} 1_{i, t-1}$ & $0.142 * *(2.219)$ & $0.178 * * *(2.598)$ & $-0.057(-0.315)$ \\
\hline$N P A_{i, t-1}$ & $-0.565 * * *(-5.743)$ & $-0.589 * * *(-5.635)$ & $-0.337(-1.152)$ \\
\hline${\text { RealEstate } \%_{i, t-1}}$ & $-0.063 * * *(-4.449)$ & $-0.067 * * *(-4.358)$ & $-0.059(-1.460)$ \\
\hline Non_Interest_Income $_{t-1}$ & $0.039(1.474)$ & $0.035(1.241)$ & $0.089(1.185)$ \\
\hline Non_Deposit_Funding $_{t-1}$ & $0.445 * * *(9.510)$ & $0.513 * * *(9.061)$ & $0.319 * * *(2.746)$ \\
\hline Liquidity_Ratio $_{i, t-1}$ & $-0.105 * * *(-2.876)$ & $-0.105 * * *(-2.675)$ & $-0.118(-1.216)$ \\
\hline Interest_Expenses $\%_{i, t-1}$ & $9.562 * * *(5.108)$ & $10.813 * * *(5.375)$ & $0.183(0.035)$ \\
\hline Size $_{i, t-1}$ & $-0.072 * * *(-5.438)$ & $-0.108 * * *(-4.837)$ & $-0.042 * *(-2.169)$ \\
\hline$R O A_{i, t-1}$ & $-2.522 * * *(-3.655)$ & $-2.664 * * *(-3.596)$ & $-1.742(-0.907)$ \\
\hline Total_Deposits $s_{i, t-1}$ & $0.026 * *(1.974)$ & $0.062 * * *(2.809)$ & $-0.007(-0.392)$ \\
\hline Tbill_3 $3 M_{t-1}$ & $1.243(0.159)$ & $1.303(0.154)$ & $0.692(0.034)$ \\
\hline$T 10 Y 3 M_{t-1}$ & $-0.073 * * *(-7.244)$ & $-0.073 * * *(-6.671)$ & $-0.076 * * *(-2.857)$ \\
\hline Ted_Rate $e_{t-1}$ & $-0.111(-1.247)$ & $-0.116(-1.209)$ & $-0.075(-0.323)$ \\
\hline Quarter fixed effect & Yes & Yes & Yes \\
\hline No. of obs. & 52119 & 45236 & 6883 \\
\hline Adj. R-Squared & 0.021 & 0.022 & 0.018 \\
\hline
\end{tabular}

Notes: The table reports the results of estimating OLS model (5) for the post-TARP period (2008Q4 to 2010Q4). Column (1) reports the OLS regression results using the sample of all banks during the postTARP period. Column (2) reports the OLS regression results for the non-TARP banks. Column (3) reports the OLS regression results for the TARP banks. Each column reports the coefficient estimates and tstatistics (in parentheses).

$* * *, * *$, and $*$ represent $1 \%, 5 \%$, and $10 \%$ significance, respectively. 
Table 3-8, columns (1) to (3) report the OLS estimation results of equation (5) for all banks, for non-TARP banks, and for TARP banks. Column (2) shows that the coefficient on $D L L P 1_{i, t-1}$ is negative and significant, and Column (3) shows that the coefficient on $D L L P 1_{i, t-1}$ is negative and less significant. The reduction in significance is consistent with our expectation that the relationship between DLLP practices and market discipline in the form of lower uninsured deposit growth rate would be weaker for banks supported by TARP. Additionally, for the TARP banks, the uninsured deposit growth rate appears less sensitive to the other risk factors, such as the Tier 1 capital ratio, non-performing loans and real estate loan ratio than for the non-TARP banks. Together, these results imply that the government bailout actions may have resulted in weakened market discipline that might otherwise punish banks for their risk-taking behaviors.

\subsubsection{Using alternative "Too-big-to-fail" bank size cut-offs}

Previously, we defined the TBTF banks as the banks above the upper 10th percentile of total assets. Now we examine the sensitivity of our results to the way we defined TBTF and non-TBTF banks. We use alternative bank size cut-offs to group TBTF banks and non-TBTF banks and examine if the previous results are robust to different bank grouping methods.

Table 3-9 reports the results of estimating OLS model (5) using alternative bank size cut-offs to group non-TBTF banks and TBTF banks. The sample period is 2001Q1 to 2010Q4. Column (1) and (2) report the results using 5\% for the size cut-off (i.e., for each quarter-year, banks with total assets in the top 5\% are grouped as TBTF banks. The other banks are grouped as non-TBTF banks). Columns (3) and (4) report the results using $15 \%$ for the size cut-off. Columns (5) and (6) report the results using $20 \%$ for the size cut-off. 
Table 3-9 Using alternative bank size cut-offs

\begin{tabular}{|c|c|c|c|c|c|c|}
\hline \multicolumn{7}{|c|}{ Dependent Variable: Uninsured_Deposit_Growth_Rate ${ }_{i, t}$} \\
\hline \multirow[t]{2}{*}{ TBTF bank size cut-off: } & \multicolumn{2}{|l|}{$5 \%$} & \multicolumn{2}{|l|}{$15 \%$} & \multicolumn{2}{|l|}{$20 \%$} \\
\hline & $\begin{array}{l}\text { non-TBTF Banks } \\
\text { (1) }\end{array}$ & $\begin{array}{l}\text { TBTF Banks } \\
\text { (2) }\end{array}$ & $\begin{array}{l}\text { non-TBTF Banks } \\
\text { (3) }\end{array}$ & $\begin{array}{l}\text { TBTF Banks } \\
\text { (4) }\end{array}$ & $\begin{array}{l}\text { non-TBTF Banks } \\
\text { (5) }\end{array}$ & $\begin{array}{l}\text { TBTF Banks } \\
\text { (6) }\end{array}$ \\
\hline (Intercept) & $0.850 * * *(23.374)$ & $-0.031(-0.211)$ & $1.019 * * *(25.405)$ & $0.120 *(1.652)$ & $1.099 * * *(25.956)$ & $0.182 * * *(2.968)$ \\
\hline$D L L P 1_{i, t-1}$ & $-2.444 * * *(-5.829)$ & $-1.684 *(-1.693)$ & $-2.808 * * *(-6.066)$ & $-1.540 * *(-2.468)$ & $-2.804 * * *(-5.782)$ & $-1.865 * * *(-3.342)$ \\
\hline $\operatorname{TIER} 1_{i, t-1}$ & $0.211 * * *(9.112)$ & $0.319 * * *(4.675)$ & $0.191 * * *(7.650)$ & $0.282 * * *(5.946)$ & $0.186 * * *(7.156)$ & $0.229 * * *(5.391)$ \\
\hline$N P A_{i, t-1}$ & $-0.741 * * *(-14.173)$ & $-1.042 * * *(-5.397)$ & $-0.761 * * *(-13.521)$ & $-0.593 * * *(-5.653)$ & $-0.764 * * *(-12.986)$ & $-0.570 * * *(-6.444)$ \\
\hline RealEstate $\%_{i, t-1}$ & $0.007(1.332)$ & $-0.032 * *(-1.981)$ & $0.015 * * *(2.711)$ & $-0.027 * * *(-2.833)$ & $0.018 * * *(3.032)$ & $-0.029 * * *(-3.507)$ \\
\hline Non_Interest_Income $_{t-1}$ & $0.067 * * *(6.134)$ & $0.007(0.253)$ & $0.067 * * *(5.552)$ & $0.025(1.539)$ & $0.065 * * *(5.094)$ & $0.029 * *(2.021)$ \\
\hline Non_Deposit_Funding $g_{t-1}$ & $0.345 * * *(14.912)$ & $0.146 * * *(4.674)$ & $0.350 * * *(13.840)$ & $0.155 * * *(7.665)$ & $0.348 * * *(12.977)$ & $0.166 * * *(9.142)$ \\
\hline Liquidity_Ratio $_{i, t-1}$ & $-0.123 * * *(-7.241)$ & $0.018(0.258)$ & $-0.140 * * *(-7.827)$ & $-0.041(-0.962)$ & $-0.149 * * *(-8.065)$ & $-0.041(-1.111)$ \\
\hline Interest_Expenses $\%_{i, t-1}$ & 6.906 *** ( 11.048$)$ & $3.297 *(1.891)$ & $7.627 * * *(11.210)$ & $2.511 * *(2.384)$ & $7.668 * * *(10.714)$ & $3.599 * * *(3.959)$ \\
\hline Size $_{i, t-1}$ & $-0.104 * * *(-9.204)$ & $-0.018 * * *(-2.707)$ & $-0.115 * * *(-9.667)$ & $-0.022 * * *(-4.887)$ & $-0.118 * * *(-9.369)$ & $-0.025 * * *(-5.726)$ \\
\hline$R O A_{i, t-1}$ & $-2.788 * * *(-9.466)$ & $0.109(0.139)$ & $-3.143 * * *(-9.699)$ & $0.386(0.815)$ & $-3.262 * * *(-9.614)$ & $0.266(0.631)$ \\
\hline Total_Deposits $_{i, t-1}$ & $0.061 * * *(5.470)$ & $0.008(1.550)$ & $0.062 * * *(5.215)$ & $0.005(1.216)$ & $0.059 * * *(4.714)$ & $0.006(1.535)$ \\
\hline Tbill_3 $3 M_{t-1}$ & $-7.952 * * *(-19.111)$ & $-2.459 *(-1.706)$ & $-8.830 * * *(-19.503)$ & $-2.533 * * *(-3.345)$ & $-9.197 * * *(-19.351)$ & $-3.042 * * *(-4.725)$ \\
\hline$T 10 Y 3 M_{t-1}$ & $-0.079 * * *(-9.488)$ & $0.045(1.444)$ & $-0.089 * * *(-9.849)$ & $0.019(1.188)$ & $-0.093 * * *(-9.850)$ & $0.008(0.601)$ \\
\hline Ted_Rate $e_{t-1}$ & $-0.115 * *(-2.000)$ & $0.429 * *(2.066)$ & $-0.170 * * *(-2.731)$ & $0.418 * * *(3.912)$ & $-0.192 * * *(-2.942)$ & $0.359 * * *(3.952)$ \\
\hline No. of obs. & 236558 & 9388 & 212517 & 33429 & 200084 & 45862 \\
\hline Adj. R-Squared & 0.020 & 0.024 & 0.021 & 0.018 & 0.022 & 0.018 \\
\hline
\end{tabular}

Notes: The table reports the results of estimating OLS model (5) using alternative bank size cut-offs to group non-TBTF banks and the TBTF banks. The sample period is 2001Q1 to 2010Q4. Appendix C provides all the variable definitions and data sources. Columns (1) and (2) report the results using 5\% as the size cutoff. Columns (3) and (4) report the results using 15\% as the size cut-off. Columns (5) and (6) report the results using 20\% as the size cut-off. Each column reports the coefficient estimates and t-statistics (in parentheses). ${ }^{* * *}, * *$, and $*$ represent $1 \%, 5 \%$, and $10 \%$ significance, respectively. 
Table 3-9 shows that when using $5 \%$ as the size cut-off, the coefficients on $D L L P 1_{i, t-1}$ are very different for the non-TBTF banks and TBTF banks. Among the nonTBTF banks, the coefficient on $D L L P 1_{i, t-1}$ is significant at the $1 \%$ level. Among the TBTF banks, the coefficient on $D L L P 1_{i, t-1}$ is only significant at the $10 \%$ level. When using $15 \%$ as the size cut-off, the difference in significance is smaller ( $1 \%$ versus $5 \%)$. When using $20 \%$ as the size cut-off, the significance is essentially the same. So, the results are sensitive to how one defines TBTF and non-TBTF banks.

\subsubsection{Using alternative DLLP measures}

As discussed in Section 3.4.2, the DLLP measures generated by different LLP models may convey different information about loan loss provisioning practices. To determine whether the results we report are robust to changes in how $D L L P$ is determined, we estimate equation (5) using $D L L P 2, D L L P 3, D L L P 4$ separately. We report the results in Table 3-10.

From Table 3-10, we see that the findings are robust to alternative $D L L P$ measures:

there is a significant negative relationship between $D L L P_{i, t-1}$ and Uninsured_Deposit_Growth_Rate $_{i, t}$ within the non-TBTF banks; and there is no significant relationship between $D L L P_{i, t-1}$ and Uninsured_Deposit_Growth_Rate $e_{i, t}$ within the TBTF banks. The values of adjusted R-squared do not change when we use different $D L L P$ measures, indicating that the influence from different $D L L P$ measures does not affect the model's explanatory power. 
Table 3-10 Using alternative $D L L P$ measures

Dependent Variable: Uninsured_Deposit_Growth_Rate $e_{i, t}$

\begin{tabular}{|c|c|c|c|c|c|c|c|c|c|}
\hline \multirow{2}{*}{$D L L P$ measures: } & \multicolumn{3}{|c|}{ DLLP2 from model (2) } & \multicolumn{3}{|c|}{ DLLP3 from model (3) } & \multicolumn{3}{|c|}{ DLLP4 from model (4) } \\
\hline & $\begin{array}{l}\text { All Banks } \\
\text { (1) }\end{array}$ & $\begin{array}{l}\text { non-TBTF Banks } \\
\text { (2) }\end{array}$ & $\begin{array}{l}\text { TBTF Banks } \\
\text { (3) }\end{array}$ & $\begin{array}{l}\text { All Banks } \\
\text { (4) }\end{array}$ & $\begin{array}{l}\text { non-TBTF Banks } \\
\text { (5) }\end{array}$ & $\begin{array}{l}\text { TBTF Banks } \\
\text { (6) }\end{array}$ & $\begin{array}{l}\text { All Banks } \\
\text { (7) }\end{array}$ & $\begin{array}{l}\text { non-TBTF Banks } \\
\text { (8) }\end{array}$ & $\begin{array}{l}\text { TBTF Banks } \\
\text { (9) }\end{array}$ \\
\hline (Intercept) & $0.749^{* * *}(21.474)$ & $0.943 * * *(24.679)$ & $0.081(0.895)$ & $0.746 * * *(21.382)$ & $0.940 * * *(24.614)$ & $0.081(0.893)$ & $0.749^{* * *}(21.474)$ & $0.943^{* * *}(24.678)$ & $0.081(0.895)$ \\
\hline$D L L P_{i, t-1}$ & $-1.378 * *(-2.550)$ & $-1.624 * * *(-2.778)$ & $-0.012(-0.010)$ & $-2.636 * * *(-6.445)$ & $-3.036 * * *(-6.745)$ & $-1.196(-1.472)$ & $-1.397 * * *(-2.580)$ & $-1.620 * * *(-2.763)$ & $-0.076(-0.065)$ \\
\hline TIER1 $_{i, t-1}$ & $0.218 * * *(9.888)$ & $0.196 * * *(8.159)$ & $0.246 * * *(4.643)$ & $0.226 * * *(10.250)$ & $0.203 * * *(8.450)$ & $0.257 * * *(4.826)$ & $0.218 * * *(9.890)$ & $0.196 * * *(8.158)$ & $0.246 * * *(4.646)$ \\
\hline$N P A_{i, t-1}$ & )$^{-0.777 * * *(-15.138}$ & )$^{-0.771 * * *(-14.034}$ & $-0.892 * * *(-7.072)$ & $-0.732 * * *(-14.343)$ & $-0.725 * * *(-13.286)$ & $-0.832 * * *(-6.575)$ & $-0.777 * * *(-15.158)$ & $-0.772 * * *(-14.066)$ & $-0.890 * * *(-7.062)$ \\
\hline RealEstate $\%_{i, t-1}$ & $-0.003(-0.710)$ & $0.014 * * *(2.599)$ & $-0.023 * *(-2.051)$ & $-0.007(-1.402)$ & $0.010 *(1.945)$ & $-0.027 * *(-2.367)$ & $-0.003(-0.707)$ & $0.014 * * *(2.610)$ & $-0.023 * *(-2.061)$ \\
\hline Non_Interest_Income $e_{t-1}$ & $0.054 * * *(5.317)$ & $0.061 * * *(5.310)$ & $0.023(1.217)$ & $0.059 * * *(5.808)$ & $0.066 * * *(5.782)$ & $0.025(1.325)$ & $0.054 * * *(5.320)$ & $0.061 * * *(5.307)$ & $0.023(1.220)$ \\
\hline Non_Deposit_Funding $g_{t-1}$ & $0.279 * * *(17.265)$ & $0.348 * * *(14.401)$ & $0.128 * * *(5.568)$ & $0.279 * * *(17.241)$ & $0.346 * * *(14.309)$ & $0.127 * * *(5.534)$ & $0.279 * * *(17.265)$ & $0.348 * * *(14.399)$ & $0.128 * * *(5.566)$ \\
\hline Liquidity_Ratio $_{i, t-1}$ & $-0.101 * * *(-6.166)$ & $-0.130 * * *(-7.506)$ & $-0.052(-1.013)$ & $-0.101 * * *(-6.136)$ & $-0.130 * * *(-7.488)$ & $-0.052(-1.019)$ & $-0.101 * * *(-6.165)$ & $-0.130 * * *(-7.504)$ & $-0.052(-1.014)$ \\
\hline Interest_Expenses $\%_{i, t-1}$ & $6.542 * * *(10.965)$ & $7.322 * * *(11.236)$ & $2.927 * *(2.362)$ & $6.537 * * *(10.961)$ & $7.269 * * *(11.156)$ & $3.039 * *(2.449)$ & $6.543 * * *(10.967)$ & $7.322 * * *(11.235)$ & $2.930 * *(2.364)$ \\
\hline Size $_{i, t-1}$ & $\begin{array}{l}-0.053 * * *(-10.922 \\
)\end{array}$ & $-0.110 * * *(-9.448)$ & $-0.020 * * *(-4.046)$ & $-0.052 * * *(-10.655)$ & $-0.107 * * *(-9.224)$ & $-0.020 * * *(-3.945)$ & $-0.053 * * *(-10.915)$ & $-0.110 * * *(-9.442)$ & $-0.020 * * *(-4.042)$ \\
\hline$R O A_{i, t-1}$ & $-2.200 * * *(-8.357)$ & $-2.308 * * *(-7.984)$ & $0.559(1.045)$ & $-2.808 * * *(-10.115)$ & $-3.042 * * *(-9.894)$ & $0.324(0.596)$ & $-2.201 * * *(-8.370)$ & $-2.305 * * *(-7.979)$ & $0.552(1.031)$ \\
\hline Total_Deposits $_{i, t-1}$ & $0.018 * * *(3.788)$ & $0.061 * * *(5.250)$ & $0.005(1.101)$ & $0.018 * * *(3.646)$ & $0.059 * * *(5.080)$ & $0.004(1.029)$ & $0.018 * * *(3.782)$ & $0.061 * * *(5.245)$ & $0.005(1.097)$ \\
\hline Tbill_3 $3 M_{t-1}$ & $\begin{array}{l}-7.548 * * *(-18.747 \\
)\end{array}$ & $\begin{array}{l}-8.468 * * *(-19.529 \\
)\end{array}$ & $-2.647 * * *(-2.849)$ & $-7.474 * * *(-18.556)$ & $-8.379 * * *(-19.315)$ & $-2.585 * * *(-2.782)$ & $-7.549 * * *(-18.750)$ & $-8.469 * * *(-19.532)$ & $-2.645 * * *(-2.847)$ \\
\hline$T 10 Y 3 M_{t-1}$ & $-0.074 * * *(-9.136)$ & $-0.084 * * *(-9.635)$ & $0.024(1.271)$ & $-0.074 * * *(-9.169)$ & $-0.084 * * *(-9.663)$ & $0.024(1.254)$ & $-0.074 * * *(-9.136)$ & $-0.084 * * *(-9.634)$ & $0.024(1.271)$ \\
\hline Ted_Rate $e_{t-1}$ & $-0.099 *(-1.777)$ & $-0.149 * *(-2.499)$ & $0.473 * * *(3.579)$ & $-0.097 *(-1.730)$ & $-0.146 * *(-2.448)$ & $0.475 * * *(3.598)$ & $-0.099 *(-1.777)$ & $-0.149 * *(-2.498)$ & $0.473 * * *(3.580)$ \\
\hline Quarter fixed effect & Yes & Yes & Yes & Yes & Yes & Yes & Yes & Yes & Yes \\
\hline No. of obs. & 245946 & 224700 & 21246 & 245946 & 224700 & 21246 & 245946 & 224700 & 21246 \\
\hline Adj. R-Squared & 0.019 & 0.021 & 0.021 & 0.019 & 0.021 & 0.021 & 0.019 & 0.021 & 0.021 \\
\hline
\end{tabular}

Notes: The table reports the results of estimating OLS model (5) using alternative DLLP measures. The sample period is 2001Q1 to 2010Q4. Appendix C provides all the variable definitions and data sources. The $D L L P$ variable used in Columns (1) - (3) is DLLP2 from estimating LLP model (2). The DLLP variable used in Columns (4) - (6) is DLLP3 from estimating LLP model (3). The DLLP variable used in Columns (7) - (9) is DLLP4 from estimating LLP model (4). Each column reports the coefficient estimates and t-statistics (in parentheses). The results are reported by all banks, non-TBTF banks, and TBTF banks.

$* * *, * *$, and $*$ represent $1 \%, 5 \%$, and $10 \%$ significance, respectively. 


\subsection{Conclusions}

This study presents evidence that suggests that depositors can recognize banks' discretionary accounting practices, measured by $D L L P$, and that they punish such practices by reducing the supply of deposits. Using U.S. commercial banks' data from call reports from 2001Q1 to 2010Q4, we find that the uninsured deposit growth rate is negatively associated with banks' DLLP practices, except for the case of TBTF banks during the crisis period.

First, the univariate analysis shows that the uninsured deposit growth rate is higher in the non-TBTF banks than in the TBTF banks. The higher uninsured deposit growth rate can be explained in two ways. First, the non-TBTF banks are using higher interest rates to attract more deposits. Second, the non-TBTF banks are safer in that these banks exhibit lower $D L L P$, higher average Tier 1 capital ratios, lower average non-performing loan ratios, and lower real estate loan ratios.

Next, we examine the relationship between DLLP practices and the uninsured deposit growth rate by controlling for effects from interest rates and other risk factors. Using call report data from 2001Q1 to 2010Q4 we find that banks with high DLLP are associated with lower uninsured deposit growth rates, lower insured deposit growth rates, as well as higher interest rates. The evidence is consistent with our first hypothesis, suggesting that depositors punish banks for their discretionary accounting practices.

To examine the effect of government guarantees on depositors' reactions to banks' $D L L P$, we perform regressions separately within the non-TBTF banks and TBTF banks. Results suggest that within the non-TBTF banks, depositors react sensitively to DLLP during both the crisis and non-crisis periods. The reaction is even stronger during the crisis 
period. However, for the TBTF banks, depositors react sensitively to DLLP practices during the non-crisis period, but not during the crisis period. This evidence suggests that during the crisis period, there is an increasing expectation among depositors that the government will step in to rescue the large banks if necessary.

During the crisis, the U.S. government took actions to bail out not only the largest banks but also other smaller banks that met the conditions for receiving bailout help. To examine if this influenced how depositors discipline banks for discretionary accounting practices, we examine the relationship between $D L L P$ and the uninsured deposit growth rate during the post-TARP period for the group of TARP banks and the group of nonTARP banks separately. We find that the uninsured deposit growth rate reacts sensitively to the non-TARP recipient banks' $D L L P$, but we do not find similar evidence among the TARP recipient banks. The results are consistent with the notion that the government's bailout actions influence how depositors apply market discipline.

In terms of policy implications, our findings suggest that, during the pre-crisis period, uninsured depositors punished banks for behaviors that increased information asymmetry between the banks and outsider creditors, but this discipline attenuated when it appeared that implicit government guarantees might be operative for some banks and when bail out funding was made available to some banks. Therefore, the sensibility of policies such as rescuing big banks or increasing deposit insurance coverage ought to be evaluated in terms of whether the benefits of such policies outweigh the potential costs of a concomitant reduction in market discipline. One of the potential costs of a reduction in market discipline is that it may induce the affected banks to engage in opportunistic 
accounting practices, thus increasing their financial reporting opacity, which may make them more difficult to regulate.

\section{References}

Acharya, V. V., Anginer, D., \& Warburton, A. J. (2016). The end of market discipline? Investor expectations of implicit government guarantees. Woking paper.

Baker, D., \& McArthur, T. (2009). The value of the 'too big to fail' big bank subsidy. Center for Economic and Policy Research Issue Brief. September.

Basel Committee on Banking Supervision (2015). Revised Pillar 3 disclosure requirements, www.bis.org

Beatty, A., \& Liao, S. (2014). Financial accounting in the banking industry: A review of the empirical literature. Journal of Accounting and Economics, 58(2-3), 339-383.

Berger, A. N. (1991). Market discipline in banking. In Federal Reserve Bank of Chicago Proceedings (No. $328)$.

Berger, A. N., \& Turk-Ariss, R. (2015). Do depositors discipline banks and did government actions during the recent crisis reduce this discipline? An international perspective. Journal of Financial Services Research, 48(2), 103-126.

Beyhaghi, M., D’Souza, C., \& Roberts, G. S. (2014). Funding advantage and market discipline in the Canadian banking sector. Journal of Banking \& Finance, 48, 396-410.

Bharath, S. T., Sunder, J., \& Sunder, S. V. (2008). Accounting quality and debt contracting. The Accounting Review, 83(1), 1-28.

Billett, M. T., Garfinkel, J. A., \& O'Neal, E. S. (1998). The cost of market versus regulatory discipline in banking1. Journal of Financial Economics, 48(3), 333-358.

Botosan, C. A. (1997). Disclosure level and the cost of equity capital. Accounting review, 323-349.

Botosan, C. A., \& Plumlee, M. A. (2002). A re-examination of disclosure level and the expected cost of equity capital. Journal of accounting research, 40(1), 21-40.

Brewer, E., \& Mondschean, T. H. (1994). An empirical test of the incentive effects of deposit insurance: The case of junk bonds at savings and loan associations. Journal of Money, Credit and Banking, 26(1), 146-164.

Bushman, R. M., \& Williams, C. D. (2012). Accounting discretion, loan loss provisioning, and discipline of banks' risk-taking. Journal of Accounting and Economics, 54(1), 1-18.

Bushman, R. M., \& Williams, C. D. (2015). Delayed expected loss recognition and the risk profile of banks. Journal of Accounting Research, 53(3), 511-553.

Bushman, R. M., Hendricks, B. E., \& Williams, C. D. (2016). Bank Competition: Measurement, DecisionMaking, and Risk-Taking. Journal of Accounting Research, 54(3), 777-826. 
Cohen, L. J., Cornett, M. M., Marcus, A. J., \& Tehranian, H. (2014). Bank earnings management and tail risk during the financial crisis. Journal of Money, Credit and Banking, 46(1), 171-197.

Cook, D. O., \& Spellman, L. J. (1994). Repudiation risk and restitution costs: Toward understanding premiums on insured deposits. Journal of Money, Credit and Banking, 26(3), 439-459.

Costello, A. M., Granja, J., \& Weber, J. (2016). Do Strict Regulators Increase the Transparency of the Banking System?.

Delis, M. D., Staikouras, P. \& Tsoumas, C (2017), Supervisory Enforcement Actions and Depositors' Reaction: Monitoring, Running, or Living a Quiet Life? (July 26, 2017). European Banking Institute Working Paper Series 2017 - no. 10.

Demirgüc-Kunt, A., \& Huizinga, H. (2010). Are banks too big to fail or too big to save? International evidence from equity prices and CDS spreads (No. 5360). The World Bank.

Diamond, D. W. (1985). Optimal release of information by firms. The journal of finance, 40(4), 1071-1094.

Diamond, D. W., \& Dybvig, P. H. (1983). Bank runs, deposit insurance, and liquidity. Journal of political economy, 91(3), 401-419.

Dou, Y., Ryan, S., \& Zou, Y. (2017). The Effect of Credit Competition on Banks' Loan Loss Provisions. Journal of Financial and Quantitative Analysis, Forthcoming.

Duffie, D., \& Lando, D. (2001). Term structures of credit spreads with incomplete accounting information. Econometrica, 69(3), 633-664.

Easley, D., \& O'Hara, M. (2004). Information and the cost of capital. The journal of finance, 59(4), 15531583.

Ellis, D. M., \& Flannery, M. J. (1992). Does the debt market assess large banks, risk?: Time series evidence from money center CDs. Journal of Monetary Economics, 30(3), 481-502.

Francis, J., LaFond, R., Olsson, P., \& Schipper, K. (2005). The market pricing of accruals quality. Journal of accounting and economics, 39(2), 295-327.

Francis, J., Nanda, D., \& Olsson, P. (2008). Voluntary disclosure, earnings quality, and cost of capital. Journal of accounting research, 46(1), 53-99.

Frank, M. Z., \& Goyal, V. K. (2008). Trade-off and pecking order theories of debt. In Handbook of empirical corporate finance (pp. 135-202). Elsevier.

Gallemore, J. (2016). Bank financial reporting opacity and regulatory intervention. Working paper

Ge, W., \& Kim, J. B. (2014). Real earnings management and the cost of new corporate bonds. Journal of Business Research, 67(4), 641-647.

Gilbert, R. A., \& Vaughan, M. D. (2001). Do depositors care about enforcement actions? Journal of Economics and Business, 53(2-3), 283-311.

Goldberg, L. G., \& Hudgins, S. C. (1996). Response of uninsured depositors to impending S\&L failures: evidence of depositor discipline. The Quarterly Review of Economics and Finance, 36(3), 311-325.

Kroszner, R. (2016). A review of bank funding cost differentials. Journal of Financial Services Research, 49(2-3), 151-174. 
Hasan, I., Jackowicz, K., Kowalewski, O., \& Kozłowski, Ł. (2013). Market discipline during crisis: Evidence from bank depositors in transition countries. Journal of Banking \& Finance, 37(12), 5436-5451.

Hribar, P., \& Jenkins, N. T. (2004). The effect of accounting restatements on earnings revisions and the estimated cost of capital. Review of accounting studies, 9(2-3), 337-356.

Hutton, A. P., Marcus, A. J., \& Tehranian, H. (2009). Opaque financial reports, R2, and crash risk. Journal of financial Economics, 94(1), 67-86.

Iannotta, G., \& Kwan, S. H. (2014, July). The impact of reserves practices on bank opacity. Federal Reserve Bank of San Francisco.

Jacewitz, S., \& Pogach, J. (2018). Deposit rate advantages at the largest banks. Journal of Financial Services Research, 53(1), 1-35.

Jiang, L., Levine, R., \& Lin, C. (2016). Competition and bank opacity. The Review of Financial Studies, 29(7), 1911-1942.

Jin, L., \& Myers, S. C. (2006). R2 around the world: New theory and new tests. Journal of financial Economics, 79(2), 257-292.

Jordan, J. S. (2000). Depositor discipline at failing banks. New England Economic Review, (Mar), 15-28.

Lester, J., \& Kumar, A. (2014). Do Bond Spreads Show Evidence of Too Big to Fail Effects? Evidence from 2009-2013 Among US Bank Holding Companies. Working paper.

Leuz, C., Verrecchia, R., (2005). Firms' capital allocation choices, information quality, and the cost of capital. University of Pennsylvania Working Paper.

Liu, C. C., \& Ryan, S. G. (2006). Income smoothing over the business cycle: Changes in banks' coordinated management of provisions for loan losses and loan charge-offs from the pre-1990 bust to the 1990s boom. The Accounting Review, 81(2), 421-441.

Maechler, A. M., \& McDill, K. M. (2006). Dynamic depositor discipline in US banks. Journal of Banking \& Finance, 30(7), 1871-1898.

Martinez Peria, M. S., \& Schmukler, S. L. (2001). Do depositors punish banks for bad behavior? Market discipline, deposit insurance, and banking crises. The journal of finance, 56(3), 1029-1051.

Merton, R. C. (1974). On the pricing of corporate debt: The risk structure of interest rates. The Journal of finance, 29(2), 449-470.

Morgan, D. P. (2002). Rating banks: Risk and uncertainty in an opaque industry. American Economic Review, 92(4), 874-888.

Nier, E., \& Baumann, U. (2006). Market discipline, disclosure and moral hazard in banking. Journal of Financial Intermediation, 15(3), 332-361.

Park, S., \& Peristiani, S. (1998). Market discipline by thrift depositors. Journal of Money, Credit and Banking, 347-364.

Prevost, A. K., Rao, R. P., \& Skousen, C. J. (2008). Earnings management and the cost of debt. Working paper. 
Richardson, V. J. (2000). Information asymmetry and earnings management: Some evidence. Review of quantitative finance and accounting, 15(4), 325-347.

Santos, J. A. (2014). Evidence from the Bond Market on Banks "Too-Big-To-Fail' Subsidy. Working paper

Sengupta, P. (1998). Corporate disclosure quality and the cost of debt. Accounting review, 459-474.

White, H. (1980). A heteroskedasticity-consistent covariance matrix estimator and a direct test for heteroskedasticity. Econometrica, 48(4), 817-838.

Wu, Y., \& Bowe, M. (2012). Information disclosure and depositor discipline in the Chinese banking sector. Journal of International Financial Markets, Institutions and Money, 22(4), 855-878. 


\section{Chapter 4: Estimating Financial Sector Risk Spillover: A Conditional Value-at-Risk Approach}

\subsection{Introduction}

In general, the financial sectors of modern economies play an important role in serving and supporting the respective real sub-sectors of those economies. Some of a financial sector's important functions are matching holders of capital with those who need it to finance projects, pooling resources into usefully large quantities, affecting payments, and managing risks, to name a few. For a comprehensive discussion see Neave (2009). If a shift to a stressed state in the financial sector raises doubts about its ability to fulfill any of these functions, adverse consequences for the entire economy can follow through a variety of transmission mechanisms, chief among them being the rapid decline in credit supply that is often associated with a shift to a stressed state in the financial sector. When credit supply declines borrowers have difficulty financing their investment or operating plans thus requiring them to alter or abandon these plans. This is especially so in real subsectors that are more dependent than others on financing from financial intermediaries (e.g., small firms, young firms, firms specializing in new products, or publicly listed firms with a short operating history). Given that it is reasonable to assume that the plans that existed before the shift to a stressed state in the financial sector were intended to be wealth-creating, altering or abandoning those plans amounts to an adverse outcome for the economy. In addition, firms that would have supplied the canceled or deferred projects experience a negative demand shock that can lead to downsizing of businesses and layoffs of personnel.

Financial crises can also create shocks to demand for consumer products, and declining demand can lead to reduced output and profit in consumer-oriented parts of the 
real sector. The 2007 to 2009 crisis in the financial sector is a good example. It originated due to issues in the U.S. sub-prime mortgage market and in markets for collateralized debt obligations that used these mortgages as underlying assets and quickly spread to real sectors in the U.S. economy and to the economies of other countries as well. The S\&P 500 Stock Index fell $28.49 \%$ in 2008 , which was its worst yearly percentage loss in history. A detailed discussion is presented in Jarrow (2011).

This study investigates the tail risk spillover effects from the financial sector to real sub-sectors using the Conditional Value-at-Risk ("CoVaR”) approach. One widely used risk measure is Value-at-Risk ("VaR"), which involves estimating the potential loss to which a financial position is exposed for a specified confidence level and time period (Tsay, 2010). For example, a person who is long S\&P/TSX 60 index units might estimate that, with a probability of .99 , the potential investment outcome over a period of one day is a loss of less than $2 \%$. Here the time period is one day, the VaR is $2 \%$ and the confidence level is $99 \%$. It is in this way that VaR focuses directly on tail risk.

One important limitation of traditional VaR is that it tends to be computed using historical return/loss data for a financial instrument - say shares in a publicly traded company - for which a VaR estimate is sought. Thus, traditional VaR tends to focus on a specific asset in isolation. Thinking in terms of an asset that is a common share in a company, VaR would not specifically address how risk, and therefore VaR, for an investment in those common shares might be increased or decreased by other firms experiencing a shift to a stressed state. For example, during the 2008 financial crisis firms in the energy sector had to defer or suspend a lot of planned projects because credit from financial intermediaries became unavailable. Meanwhile, households and businesses began 
spending less on things like energy-consuming vehicles, appliances, and business operating equipment, leading to declines in energy demand (Birol, 2009). If an energy firm were to estimate its VaR using its own historical stock return data, it could underestimate the VaR of a holding in its common shares by ignoring contributions to $\mathrm{VaR}$ originating from sources not necessarily reflected its own stock return history. It is in this way that traditional VaR does not necessarily inform users about risk transmitted from the financial sector as it shifts from a normal state to a stressed state. This study addresses this matter by explicitly including contributions to risk from the financial sector to real sub-sectors and examining the effect of doing so on risk estimations.

CoVaR used in this study measures VaR for real sub-sectors conditional on VaR in the financial sector. A member of the real sector with elevated CoVaR is more susceptible to being affected by a tail event in the financial sector than a member with lower CoVaR. To be more specific, we are interested in questions such as, "What is the energy sector's CoVaR when the financial sector is in a normal state?" and, "What is the change in the energy sector's CoVaR when the financial sector shifts from a normal state to a stressed state?" The CoVaR approach enables users to identify which real sub-sectors are more likely or less likely to be affected by risks that originate in the financial sector.

Building on the quantile regression framework proposed by Koenker and Bassett (1978), Engle and Manganelli (2004) develop the Conditional Autoregressive Value-atRisk ("CAVaR") model, suggesting that VaR can be conditional on current information. Adrian and Brunnermeier (2016) develop a CoVaR measure to explore the conditional risk relationship within the U.S. banking sector, focusing on how the entire banking system's VaR is affected by individual banks' respective VaR. Our approach is related to their 
studies, using the Conditional-VaR approach ( $\mathrm{CoVaR})$ with quantile regression to evaluate conditional risk. Unlike most of the previous literature that limits its focus to risk contagion within the financial sector, we focus on risk spillover from the financial sector to various real sub-sectors.

The empirical strategy and empirical findings in this study are as follows. First, we estimate a CoVaR model for each of the real sub-sectors using quantile regression and data for the period 2005-01-04 to 2017-12-29. The quantile regression results reveal that the financial sector's stock returns significantly contribute to the real sectors' tail risk in stock returns.

To trace time-varying spillover effect, we use 500-day rolling windows over the period spanned by our sample data to estimate the CoVaR model for each real sub-sector on a daily basis. We find that the spillover effect from the financial sector to real subsectors reached the highest levels in our sample period just before the 2008 financial crisis and decreased once the financial crisis had started.

Qualitatively, we find that both VaR and CoVaR appear to be sensitive to changes in the underlying return loss process and show a high level of risk during the 2008-2009 crisis period. The values of $\mathrm{CoVaR}$ measures are consistently larger than the values of $\mathrm{VaR}$ measures over time, suggesting that $\mathrm{CoVaR}$ measures can be used as more conservative risk measures than VaR measures.

To examine which real sub-sectors appear to be riskier than others, we ranked the real sub-sectors using the mean values of the daily estimates of VaR, CoVaR, and $\Delta \mathrm{CoVaR}$. We find that the Mining, Steel, Oil, and Cars sectors are ranked among the riskiest sectors using either risk indicator. 
We then examine the risk-predicting ability of CoVaR and traditional VaR models using back-testing method. The statistical test results in the Bernoulli Coverage test show that the CoVaR model performs better than the VaR model during the financial crisis period. The contribution of the CoVaR model appears to be that it can be a more reliable indicator of risk during very volatile market periods, e.g., the crisis period. Our results also suggest that, outside of crisis periods, both models appear to generate conservative estimates of boundary losses.

Finally, to understand the time path of risk spillover, we use impulse response functions ("IRFs") to determine the magnitude and duration of responses in real sub-sectors to shocks in the financial sector. Our results show that the real sub-sectors' stock returns respond to shocks originating from the financial sector's stock returns immediately (in one day) and that the effects attenuate over the ensuing two weeks to a negligible level.

Using U.S. commercial bank data from 2001Q1 to 2010Q4, we find that uninsured deposit growth is negatively associated with banks' $D L L P S$. The findings suggest that depositors punish banks' discretionary accounting practices. We also find that within the non-TBTF banks, depositors react sensitively to DLLP during both the crisis and non-crisis periods. However, for those TBTF banks, depositors react sensitively to DLLP practices only during the non-crisis period, but not during the crisis period. In addition, we find that banks subject to US government bailout actions during the 2008-2009 crisis period received less depositor discipline than other banks.

This study contributes to the literature in several ways. First, it complements existing literature that examines the risk spillover effects from the financial sector to real sub-sectors. The existing literature typically examines the effect of shocks using each sub- 
sector's value-added growth rate (e.g., Rajan and Zingales, 1998; Kroszner, Laeven, and Klingebiel, 2007), industry output volatility (e.g., Raddatz, 2006), or industry stock price performance (e.g., Tong and Wei, 2008). We complement the literature by focusing directly on tail risk measures. Unlike previous studies, we do not seek to examine the channel(s) through which crises from the financial sector are transmitted to real sub-sectors (i.e., shocks to credit supply, or shocks to product demand). Instead, we focus on each real sub-sector's aggregate risk conditional on the state (normal or stressed) of the financial sector.

Second, the methodology used in this study is related to a growing literature using $\mathrm{CoVaR}$, which is typically used to examine risk in one firm conditional on risk in another firm. While the CoVaR approach is being adopted increasingly in studies focusing on systemic risk within the financial sector, few studies adopt this approach to study risk dependence between pairings of sub-sectors of the economy, specifically in this study, in pairings of the financial sector with each of the individual real sub-sectors, respectively. To the best of our knowledge, this is the first study to use the CoVaR approach to explore conditional risk between the financial sector and real sub-sectors.

Third, the tail risk measure for real sub-sectors developed in this study is useful for policymakers and regulators because it helps them understand more fully the way in which real sub-sectors are connected to the financial sector. This understanding can help them apply valuable and scarce regulatory and policy formulation efforts in a more informed way. For example, banking regulators in economies that are heavily weighted toward real sub-sectors that are very sensitive to risk emanating from the banking sector may regulate more strictly than for economies largely composed of real sub-sectors that are relatively 
immune to risk emanating from the banking sector. Also, regulators may approach decisions to forebear differently for similar reasons.

In Section 4.2 we review the literature that is foundational to this study. In Section 4.3 we describe and discuss the traditional VaR model and the CoVaR model empirical strategies. In Section 4.4 we present the empirical results. Finally, Section 4.5 concludes.

\subsection{Literature review}

\subsubsection{Stress in the financial sector and consequences for real sub-sectors}

A large literature, dating back to Joseph Schumpeter (1911), emphasizes that technological innovation and economic development benefit from services provided by financial intermediaries. Levine (1997) summarizes the function of the financial intermediaries as "mobilize savings, allocate resources, exert corporate control, facilitate risk management, ease trading of goods, services, contracts" (p.691). The failure of a financial intermediary therefore creates negative effects that are external to the failed intermediary because it amounts to a partial withdrawal of these valuable services for the economy.

Drawing from the existing literature, we introduce two kinds of shocks from the financial sector that can affect stock price performance in real sub-sectors: a reduction in credit supply to real sub-sectors, and a contraction in product demand in real sub-sectors. Although our study does not seek to identify the channel(s) through which shocks from the financial sector are transmitted to real sub-sectors, we are interested in existing evidence concerning those channels. This evidence helps explain why some real sub-sectors are 
more vulnerable to shocks from the financial sector than others, and therefore, may also help explain variation in empirical results across real sub-sectors in this study.

\subsubsection{Credit supply shocks}

Shocks in the financial sector may cause a shortage of funding liquidity in banks, thus reducing banks' inclination or ability to lend, even to financially healthy firms, in the real sector. Consequently, real sub-sectors comprised of firms that require more external financing than others can be expected to suffer more than other real sub-sectors during financial crises. A large literature explores how the state of financial markets, and the behaviour of financial intermediaries and their lending decisions, have discernable consequences for firms in the real sector. Bernanke and Blinder (1988) show that a negative shock, which is typically associated with a tightening of monetary policy, affects banks' lending ability, leading to a decline in real economic activity. Further evidence of interaction between the financial sector and real sub-sectors can be found in Rajan and Zingales (1998). They find that industrial sectors that are relatively more dependent on external financing grow disproportionately faster in countries with more developed financial markets. Following their work, Kroszner, Laeven, and Klingebiel (2007), and Dell'Ariccia, Detragiache, and Rajan (2008) investigate the effects of banking crises and find that real sub-sectors that are more dependent on external financing perform relatively worse during banking crises. Braun and Larrain (2005) find that industries that are more dependent on external financing exhibit a larger drop in growth during recessions than other industries. They also find that this effect is larger in industries whose assets are less tangible than in other industries, and therefore less able to support the borrower-lender relationship than tangible assets. Raddatz (2006) finds evidence that a well-developed 
financial market reduces output volatility in industries that are more dependent on external financing than other industries. Laeven and Valencia (2013) show that the growth is larger for firms in industries that are more dependent on external financing in countries where governments help to restore bank capital during crises, indicating that bank lending matters. Chava and Purnanandam (2011) investigate the 1998 Russian financial crisis and find that firms that rely primarily on bank financing perform worse in equity markets compared to the firms with access to public debt markets.

Overall, this strand of literature suggests that industries that are financed primarily with internal funds should be relatively immune to shocks to financial intermediaries, and conversely, that industries that depend on bank financing should suffer more than other industries when there are shocks to financial intermediaries.

\subsubsection{Product demand shock}

In addition to reducing credit supply to the real sector, financial sector crises may lead to a contraction in consumer demand and its attendant consequences.

Calomiris, Love and Pería (2012) focus on shocks to global trade. They capture firms' sensitivity to product demand shocks using the share of foreign sales to total sales. They find that monthly equity returns performance can be explained by firms' sensitivity to global trade demand shocks during crisis periods. They do not find the same effect during non-crisis periods.

Using firms' stock price change after the 9/11 attack, Tong and Wei (2008) construct an index of consumer demand sensitivity at the industry-level. They assume that changes in stock price after 9/11 capture firms' vulnerability to a loss in confidence in the economy. They find evidence that both the effect of credit constraint and the effect of 
reduced consumer confidence are at work, but the effect from credit constraint is more significant in explaining cross-firm differences in stock price declines. Grammatikos and Vermeulen (2014) use the same index and find that industries that are more sensitive to demand shocks experienced larger losses during the 2008 U.S. financial crisis.

In general, evidence from the literature suggests that, during financial crises, firms that are sensitive to demand shocks perform worse than other firms.

Although many studies examine why some real sub-sectors are more vulnerable than others during financial crises, there remain some important open questions that we examine in this study:

a) How quickly do shocks from the financial sector transmit to real sub-sectors;

b) How quickly do the real sub-sectors respond; and,

c) How long does the response persist?

\subsubsection{Methods in measuring risk transmission}

The topic of financial crisis transmission gained a lot of attention after the East Asian financial crisis in the late 1990s. Risk contagion among stock markets around the world has been studied using a range of different methodologies. One test examines changes in the correlation coefficients for stock prices across different stock markets. In this literature, contagion is defined as an increase in cross-market correlation (e.g., Baig and Goldfajn, 1999; and Bekaert and Harvey, 2003). Another commonly used method is to estimate spillovers in volatility by estimating multivariate GARCH processes (e.g., Park and Song, 2001). A few extreme-value-theory based studies focus on extreme moments in asset prices and examine whether market co-movements increase during crisis periods (e.g., Hartmann, Straetmans, and de Vries, 2004, and Chan-Lau, Mathieson, and Yao, 2004). 
Claessens and Forbes (2004) review and discuss the applications and limitations of these methods. In recent years, the global vector autoregression model ("GVAR") has been widely adopted in studying cross-border risk transmission (e.g., Dees, di Mauro, Pesaran, and Smith, 2007). Overall, these studies focus on the cross-border risk transmission mechanism because most of them are motivated to understand why a country-specific crisis in the East Asian financial crisis could spread internationally.

This study extends the literature by developing a tail risk measure that can capture the change in risk in real sub-sectors that follows from an elevation of risk in the financial sector. Our approach is closely related to the CoVaR approach that was first proposed by Adrian and Brunnermeier in 2008 in Federal Reserve Staff Report No. 348, revised in later years, and formally published in 2016.

CoVaR is used to measure the spillover effects of tail events, capturing one firm's contribution to another firm's tail risk based on market data. According to the authors, "Co" in $\mathrm{CoVaR}$ stands for conditional, co-movement, contagion, or contributing. This measure was developed in the context of the 2008 financial crisis. At that time there were perceptions of increased risk caused by counterparty credit risk or funding liquidity problems, so there was increased interest in finding ways to understand, measure and address systemic risk.

The basic idea behind CoVaR is that the distribution of stock returns (or asset values) of one firm can depend on the financial health of another firm. One can extend this idea to the notion that returns in a real sub-sector of the economy can depend on the health of the financial sector of the economy. The risk in the financial sector, considered in its entirety, depends on the respective financial conditions of the financial institutions that 
comprise it and their effects on each other. When one financial institution enters a stressed state, risk in the financial sector will change, in part because the riskiness of one of its members changed, but also because that change in riskiness can affect the riskiness of all of its other members. The research focus of Adrian and Brunnermeier (2016) is the change in $\mathrm{CoVaR}$ of the financial sector, in its entirety, when an individual financial institution goes from a normal state to a stressed state. Using weekly U.S. financial institution data, they examine the contribution to systemic risk of each individual financial institution. They find that systemic risk, as measured by changes in CoVaR, is very different from each financial institution's risk in isolation, as measured by VaR.

Girardi and Ergun (2013) use multivariate GARCH estimation rather than quantile regression to estimate CoVaR by using daily data for four groups of U.S. financial institutions (deposit-taking institutions, securities dealers and commodity brokers, insurers, and others). They find that deposit-taking institutions are the biggest contributors to systemic risk. Adam, Füss, and Gropp (2014) develop a state-dependent sensitivity valueat-risk (“SDSVaR") to evaluate risk spillovers among four U.S. financial institution groups (commercial banks, investment banks, hedge funds, and insurance companies). They find that the size of risk spillovers among the four sets of financial institutions is larger when the market is in a volatile state than when it is in a normal state.

In addition to the U.S. evidence, some studies adopt CoVaR to examine risk contagion among different economies. López-Espinosa, Moreno, Rubia, and Valderrama (2012) compute weekly CoVaR by constructing a global financial system with 54 large international banks and examining the bank-level determinants of CoVaR. Wong and Fong (2011) adopt the CoVaR approach to examine the tail risk relationship among 11 Asia- 
Pacific economies using daily sovereign credit default swap (“CDS”) spreads. Using the same approach, Fong and Wong (2012) analyze the risk spillovers among European sovereigns.

Jinjarak and Zheng (2014) examine the international equity market interdependence based on the CoVaR approach. They find that the idiosyncratic shocks to the largest equity funds investing in the U.S. have an economically significant effect on the funds in the non-U.S. markets.

One role for CoVaR is to use it as a tool to identify or rank systemically important (too-connected-to-fail) financial institutions. For example, Sharifova (2012) rank the bank importance of a set of U.S. and European banks based on their systemic risk contribution to banks in other countries/continents as measured by the change in CoVaR. Castro and Ferrari (2014) develop a way to statistically test whether the systemic risk contribution, as measured by the change in CoVaR, for a given institution is significant and test whether the 26 large European banks in their sample are systemically important."

In this study, we are looking at the contribution to tail risk in real sub-sectors from tail risk in the financial sector. Unlike previous studies, which tend to focus on how one institution contributes risk to a system or group of institutions, we focus on how the financial sector contributes risk to respective real sub-sectors when additional risk arises in the financial sector. By investigating the changes in each sector's CoVaR when the financial sector shifts from a normal state to a stressed state, we seek to identify which sectors are more sensitive than others to change in risk in the financial sector during a financial crisis. 
Details of the VaR and CoVaR estimation procedures are described and discussed in Section 4.3.

\subsection{VaR and CoVaR approaches}

\subsubsection{VaR and quantile regression}

One of the most commonly used risk measures is VaR. VaR can be simply described in the following way:

$$
\operatorname{Pr}\left(r \leq \operatorname{VaR}_{q} \mid \Omega\right)=q
$$

In this equation, $r$ is the return for the portfolio or institution of interest for a prespecified time interval - often just one day - and $q$ is an arbitrarily chosen, often small probability. VaR is the benchmark return level at which the probability of an outcome worse than VaR is $q . \Omega$ denotes current information. To establish an example let us assume that setting $q$ equal to $5 \%$ corresponds to a $\mathrm{VaR}$ of $-2.5 \%$ over one day, or equivalently, that setting VaR equal to $-2.5 \%$ over one day corresponds to $q$ equal to $5 \%$. In either case this is expressed as $V a R_{5 \%}=-2.5 \%$ (see Figure 4-1). The interpretation of equation (1) is that $5 \%$ of time the outcome on a $\$ 1$ investment over one day will be $\$ 1 \times V a R_{5 \%}$ or worse - that is, the outcome is a negative dollar amount and therefore a loss. Expressed consistently with equation we have:

$$
\operatorname{Pr}(r \leq-2.5 \% \mid \Omega)=5 \%
$$


Figure 4-1 Value-at-Risk example

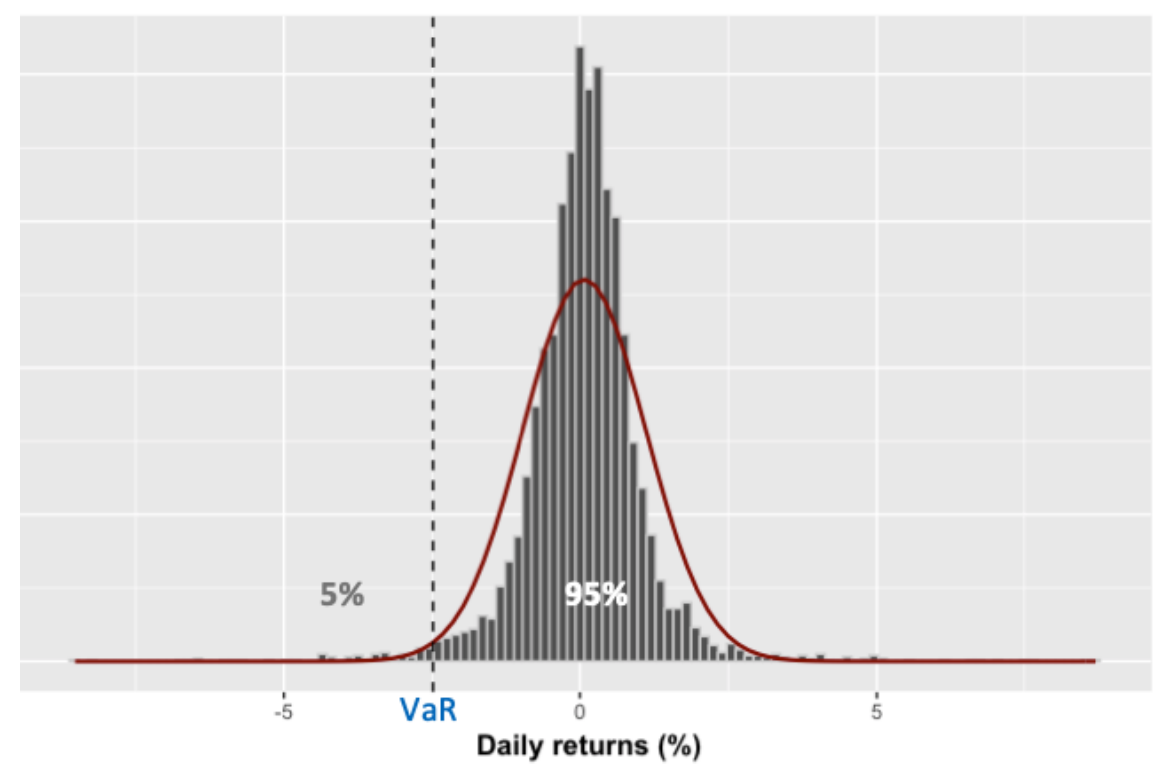

Some authors prefer to multiply returns by -1 . Doing so causes negative returns, or equivalently losses, to appear as positive values, so the need to interpret negative percentages as losses is dispensed with. The outcome from multiplying \$1 of investment by $\mathrm{VaR}$ is then a dollar loss expressed as a positive value. This is the approach commonly used in the literature, so we adopt it in the discussion that follows. Using the percentage assumptions from the numerical example provided above, this approach results in expressing $\mathrm{VaR}$ in the following way:

$$
\operatorname{Pr}(r \leq 2.5 \% \mid \Omega)=95 \%
$$

So $\operatorname{VaR}_{95 \%}=2.5 \%$. This is interpreted as $95 \%$ of the time, the loss of $1 \$$ investment will be no larger than $\$ 1 \times \operatorname{VaR}_{95 \%}$ over one day (see Figure $4-2$ ). 
Figure 4-2 Value-at-Risk example: equivalent illustration

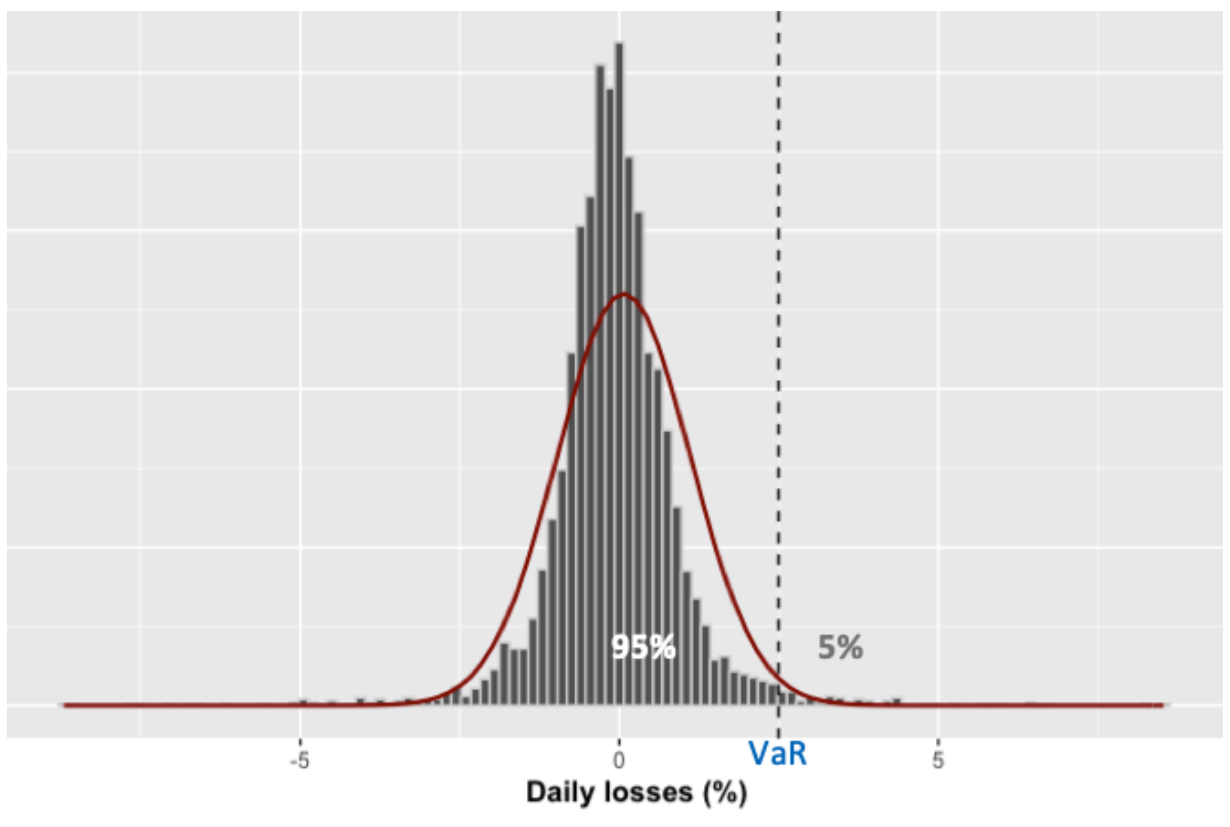

VaR can be estimated using classical econometric models such as Riskmetrics and GARCH. These models assume $r_{t} \mid \Omega$ follows some kind of distribution (e.g., the normal distribution or the student-t distribution). Then, the quantiles are calculated using the mean and variance of the distributions. The classical models are often criticized for assuming the nature of the distribution for an entire return series.

The quantile regression method, introduced by Koenker and Bassett (1978) and developed by Engle and Manganelli (2004), is an approach to modeling the quantile of return series directly ${ }^{25}$. One advantage of using quantile regression to estimate VaR is that for the distribution function $r_{t} \mid \Omega$, quantile regression is able to include a set of explanatory variables in $\Omega$. For example, monetary policy decisions made by the U.S. Federal Reserve

\footnotetext{
${ }^{25}$ Bošković, Laplace, and Edgeworth worked on median regression in the 1700 s and 1800 s. They can be considered as a prelude to Koenker and Bassett (1978)'s contribution to quantile regression.
} 
Bank could have important consequences for U.S. stock returns. To account for this, interest rate levels can be included in $\Omega$.

Assume the current information $\Omega$ includes vectors of state variables denoted $M_{t-1}$. We can write down a linear model in the following way:

$$
r_{t}=\beta_{0}+\beta_{1} M_{t-1}+\epsilon_{t}
$$

In equation (4), $r_{t}$ denotes the realized return percentage multiplied by $-1, \beta_{0}$ is a regression coefficient and $\beta_{1}$ is a vector of regression coefficients corresponding to each element in the vector $M_{t-1} . \epsilon_{t}$ is the error term. We use $\boldsymbol{\beta}$ to denote the vector of regression coefficients $\beta_{0}$ and $\beta_{1}$. We use $\widehat{\boldsymbol{\beta}}_{\boldsymbol{q}}$ to denote the vector of estimated regression coefficients $\hat{\beta}_{0, q}$ and $\hat{\beta}_{1, q}$ associated with quantile $q$.

The ordinary least squares ("OLS") method is not appropriate for estimating $\boldsymbol{\beta}$ because it establishes the relationship between $M_{t-1}$ and the conditional mean of the dependent variable $r_{t}$. We are interested in how $M_{t-1}$ is related, differentially, to a particular quantile of $r_{t}$. Quantile regression, on the other hand, provides a way to estimate the conditional quantiles of the response variables given certain values of the predictor variables. Thus, we apply the quantile regression framework proposed by Koenker and Bassett (1978) who show that $\widehat{\boldsymbol{\beta}}_{\boldsymbol{q}}$ is determined by minimizing the weighted absolute values in equation (5):

$$
\widehat{\boldsymbol{\beta}}_{\boldsymbol{q}}=\operatorname{argmin}_{\boldsymbol{\beta}} \Sigma_{t=1}^{n} \begin{cases}q\left|r_{t}-\beta_{0}-\beta_{1} M_{t-1}\right| & \text { if }\left(r_{t}-\beta_{0}-\beta_{1} M_{t-1}\right) \geq 0 \\ (1-q)\left|r_{t}-\beta_{0}-\beta_{1} M_{t-1}\right| & \text { if }\left(r_{t}-\beta_{0}-\beta_{1} M_{t-1}\right)<0\end{cases}
$$


Using $\hat{\beta}_{0, q}$ and $\hat{\beta}_{1, q}$ in equation (4) produces:

$$
\operatorname{VaR}_{q, t}=\hat{r}_{q, t}=\hat{\beta}_{0, q}+\hat{\beta}_{1, q} M_{t-1}
$$

Equations (4), (5) and (6) are expressed for returns generally. We will be concerned with returns and VaR for particular real sub-sectors and for the financial sector, so returns in what follows will be super-scripted to denote this. For example, a VaR estimation for the financial sector depends on returns for the financial sector, denoted $r_{t}^{F}$, so equation (6) for the financial sector is the following:

$$
\operatorname{VaR}_{q, t}^{F}=\hat{r}_{q, t}^{F}=\hat{\beta}_{0, q}+\hat{\beta}_{1, q} M_{t-1}
$$

\subsubsection{CoVaR}

CoVaR uses a conceptual method similar to VaR. According to Adrian and Brunnermeier (2016), $\operatorname{CoVaR}_{q}^{j \mid i}$ is defined as the $q$ quantile $\mathrm{VaR}$ for institution $j$ conditional on the contemporaneous level of the $q$ quantile VaR in sector $i$.

In this study, we examine returns for sectors rather than institutions, and the conditioning sector, sector $i$, is the always the financial sector. Conditioning is achieved by adding financial sector returns $r_{t}^{F}$ as an explanatory variable in the equation defining a sector $j$ 's returns $r_{t}^{j \mid F}$, effectively an expansion of equation (4):

$$
r_{t}^{j \mid F}=\alpha_{0}+\alpha_{1} M_{t-1}+\alpha_{2} r_{t}^{F}+\epsilon_{t}
$$


We use $\boldsymbol{\alpha}$ to denote the vector of regression coefficients $\alpha_{0}, \alpha_{1}$ and $\alpha_{2}$ and $\widehat{\boldsymbol{\alpha}}_{\boldsymbol{q}}$ to denote the vector of estimated regression coefficients $\hat{\alpha}_{0, q}, \hat{\alpha}_{1, q}$ and $\hat{\alpha}_{2, q}$ associated with quantile $q$. We use quantile regression to determine the estimated coefficients $\widehat{\boldsymbol{\alpha}}_{\boldsymbol{q}}$ in the following way:

$\widehat{\boldsymbol{\alpha}}_{\boldsymbol{q}}=\operatorname{argmin}_{\boldsymbol{\alpha}} \Sigma_{t=1}^{n}\left\{\begin{array}{l}q\left|r_{t}^{j}-\alpha_{0}-\alpha_{1} M_{t-1}-\alpha_{2} \mathrm{r}_{t}^{F}\right|, \quad \text { if }\left(r_{t}^{j}-\alpha_{0}-\alpha_{1} M_{t-1}-\alpha_{2} \mathrm{r}_{t}^{F}\right) \geq 0 \\ (1-q)\left|r_{t}^{j}-\alpha_{0}-\alpha_{1} M_{t-1}-\alpha_{2} \mathrm{r}_{t}^{F}\right|, \quad \text { if }\left(r_{t}^{j}-\alpha_{0}-\alpha_{1} M_{t-1}-\alpha_{2} \mathrm{r}_{t}^{F}\right)<0\end{array}\right.$

Using the estimated coefficients $\widehat{\boldsymbol{\alpha}}_{\boldsymbol{q}}$ from equation (9), $\operatorname{CoVaR} R_{q, t}^{j \mid F}$ is determined in the following way:

$\operatorname{CoVaR}_{q, t}^{j \mid F}=\operatorname{VaR}_{q, t}^{j \mid r^{F}=\operatorname{VaR} R_{q}^{F}}=\hat{\alpha}_{0, q}+\hat{\alpha}_{1, q} M_{t-1}+\hat{\alpha}_{2, q} \hat{r}_{q, t}^{F}=\hat{\alpha}_{0, q}+\hat{\alpha}_{1, q} M_{t-1}+\hat{\alpha}_{2, q} \operatorname{VaR} R_{q, t}^{F}$

In equation (10), $\hat{r}_{q, t}^{F}$ is determined from equation (7) and $\hat{\alpha}_{2, q}$ is interpreted as a measure of the contribution to sector $j$ 's risk emanating from the financial sector.

Next, we examine the change in the CoVaR of sector $j$ conditional on a change in the financial sector's returns from median levels determined as $V a R_{50 \%, t}^{F}$ to extreme levels proxied by the financial sector's $\operatorname{VaR}_{q, t}^{F}$. This difference, which Adrian and Brunnermeier (2016) call $\Delta \operatorname{CoVaR} R_{q, t}^{j \mid F}$, is determined for each sector as follows:

$$
\Delta \operatorname{CoVaR}_{q, t}^{j \mid F}=\operatorname{CoVaR}_{q, t}^{j \mid F}-\operatorname{CoVaR}_{50 \%, t}^{j \mid F}=\hat{\alpha}_{2, q}\left(\operatorname{VaR}_{q, t}^{F}-\operatorname{VaR}_{50 \%, t}^{F}\right)
$$


To summarize the above estimation procedures for computing $\mathrm{VaR}, \mathrm{CoVaR}$, and $\triangle$ CoVaR:

Step 1: Obtain financial sector's $\operatorname{VaR}_{q, t}^{F}$ using equations (4) - (7).

Step 2: Compute CoVaR for each real sub-sector using equations (8) - (10).

Step 3: Compute $\Delta$ CoVaR for each real sub-sector using equation (11).

CoVaR and $\triangle$ CoVaR measure different phenomena, and respectively, they can be used in different scenarios. CoVaR can be used to infer the sizes of the losses in real subsectors, respectively, that originate in the financial sector. $\triangle$ CoVaR can be used as a measure of the additional contribution to real sub-sectors' risk when the financial sector shifts from a normal state as proxied by $V a R_{50 \%, t}^{F}$ to a stressed state, as proxied by $V a R_{q, t}^{F}$. A larger $\triangle \mathrm{CoVaR}$ for a real sub-sector indicates that the real sub-sector is more sensitive to shocks from the financial sector than a real sub-sector with smaller $\Delta \operatorname{CoVaR}$. Thus, $\triangle \mathrm{CoVaR}$ can help risk managers understand the boundary for large losses in their respective real sub-sector during a financial crisis. Managers or investors in high $\Delta$ CoVaR real sub-sectors could moderate their risk-taking behaviour, or perhaps their levels of supporting capital if a crisis in the financial sector seems imminent.

\subsection{Data and empirical results}

\subsubsection{Data and summary statistics}

We use U.S. industry-level return data to examine industry-level VaR, CoVaR, and $\Delta$ CoVaR. The U.S. industry portfolio returns are obtained from Kenneth R. French's data 
bank $^{26}$. According to the description from Kenneth R. French's data bank, each stock in the NYSE, AMEX, and NASDAQ is assigned to an industry portfolio at the end of June of each year based on its 4-digit SIC code at that time. The SIC code is obtained from Compustat and CRSP.

We obtain the average daily weighted returns from 17 industry level portfolios. A definition for each of the industries is provided in Appendix D. One portfolio corresponds to the financial sector and each of the rest corresponds to a real sub-sector. The sample period is from 2005-01-04 to 2017-12-29 and is comprised of 3,188 observations for each sector. As suggested by Tsay (2010), we transform the raw daily industry return data $x_{t}$ into mean-corrected negative $\log$ returns $r_{t}$ for use in our quantile regression estimations ${ }^{27}$ :

$$
r_{t}=-\log \left(x_{t}-\bar{x}+1\right), \quad \bar{x}=\frac{1}{n} \sum_{t=1}^{n} x_{t},
$$

where $n$ is the number of observations.

In addition to the return data, we need to construct a set of state variables $M_{t-1}$. The state variables are intended to capture time variation in $r_{t} \mid \Omega$. Based on Adrian and Brunnermeier (2016), we choose the following variables to be included in $M_{t-1}$ :

- $\quad V I X$ : Implied stock market volatility, as measured by the VIX index, available at the Chicago Board Options Exchange (CBOE).

\footnotetext{
${ }^{26}$ The data is available at http://mba.tuck.dartmouth.edu/pages/faculty/ken.french/data_library.html. ${ }^{27}$ Log returns are widely used in financial time series data for various reasons such as normalization and time-additivity.
} 
- $S P$ : Market performance as measured by S\&P500 returns, which are available from CRSP.

- TED: A funding liquidity measure of the short-term TED spread, defined as the difference between the three-month LIBOR rate and the three-month Treasury bill rate. The LIBOR rate is available from the British Banker's Association. The Treasury Bill rate is available from the Federal Reserve Board's H.15 release.

- T3M: The change in the 3-month Treasury Bill rate.

- T103: The change in term spread, measured as the difference between longterm (10-year) bond yield and the three-month Treasury bill rate. Both rates are available from the Federal Reserve Board's H.15 release.

- VOL: stock return volatility for each sector, which is computed as the 22-day rolling window standard deviation of the daily stock returns.

Table 4-1 reports summary statistics for $r_{t}$ for the 16 real sub-sectors and for the financial sector. Since the return data is mean-corrected, the skewness of all return series is close to zero. The financial sector's kurtosis is the highest among the 17 sectors, suggesting a fat tail in that sector's return distribution. We also report the summary statistics for the state variables $M_{t-1}$ in Table 4-2. 
Table 4-1 Summary statistics for sector returns

\begin{tabular}{lrrrrrrrr}
\hline & \#Obs & Minimum & Maximum & Mean & Median & Stdev & Skewness & Kurtosis \\
\hline Finan & 3188 & -8.5300 & 8.7000 & 0.0474 & 0.0700 & 1.1587 & 1.1587 & 0.0136 \\
Food & 3188 & -7.0900 & 5.7400 & 0.0547 & 0.0900 & 0.9724 & 0.9724 & -0.4718 \\
Mines & 3188 & -13.0500 & 13.4400 & 0.0332 & 0.0700 & 2.2304 & 2.2304 & -0.2335 \\
Oil & 3188 & -16.1700 & 11.4900 & 0.0283 & 0.1000 & 2.2839 & 2.2839 & -0.3165 \\
Clths & 3188 & -9.6200 & 7.5900 & 0.0542 & 0.1000 & 1.4272 & 1.4272 & -0.2310 \\
Durbl & 3188 & -8.7000 & 11.5300 & 0.0325 & 0.0800 & 1.2922 & 1.2922 & -0.1532 \\
Chems & 3188 & -11.3800 & 13.8300 & 0.0496 & 0.1050 & 1.5799 & 1.5799 & -0.2841 \\
Cnsum & 3188 & -7.4600 & 6.4100 & 0.0669 & 0.1500 & 1.2464 & 1.2464 & -0.3394 \\
Cnstr & 3188 & -10.7900 & 16.3900 & 0.0486 & 0.0800 & 1.6425 & 1.6425 & 0.1083 \\
Steel & 3188 & -14.1600 & 12.8400 & 0.0425 & 0.0800 & 2.0603 & 2.0603 & -0.2638 \\
FabPr & 3188 & -9.5500 & 7.8800 & 0.0620 & 0.1050 & 1.5382 & 1.5382 & -0.3072 \\
Machn & 3188 & -8.3900 & 7.3600 & 0.0525 & 0.1300 & 1.3662 & 1.3662 & -0.3763 \\
Cars & 3188 & -12.4000 & 10.2900 & 0.0478 & 0.1300 & 1.7614 & 1.7614 & -0.0387 \\
Trans & 3188 & -8.5800 & 7.7700 & 0.0502 & 0.0900 & 1.4428 & 1.4428 & -0.2108 \\
Utils & 3188 & -8.1100 & 8.0700 & 0.0451 & 0.1000 & 1.0590 & 1.0590 & -0.3513 \\
Rtail & 3188 & -9.3800 & 8.3800 & 0.0363 & 0.0900 & 1.3507 & 1.3507 & -0.1438 \\
Other & 3188 & -8.2300 & 5.9600 & 0.0520 & 0.1400 & 1.2004 & 1.2004 & -0.4373 \\
\hline Notes: This
\end{tabular}

Notes: This table reports summary statistics for the raw returns (i.e., returns without any transformation). Mean, Median, and Standard Deviation are reported as percentages. The data is comprised of daily observations from 2005-01-04 to 2017-12-29 with 3188 observations for each sector. We delete the observations with missing values in returns or state variables. Sectors are defined based on Compustat SIC and CRSP SIC codes (see Appendix D for sectors' definitions). 
Table 4-2 Summary statistics for state variables

\begin{tabular}{|c|c|c|c|c|c|c|c|c|}
\hline & \#Obs & Minimum & Maximum & Mean & Median & Stdev & Skewness & Kurtosis \\
\hline$V I X$ & 3188 & 9.1400 & 80.8600 & 18.7668 & 15.8700 & 9.2912 & 2.5065 & 8.4365 \\
\hline$S P$ & 3188 & -9.4695 & 10.2457 & 0.0183 & 0.0603 & 1.1812 & -0.6206 & 10.5656 \\
\hline$T 3 M$ & 3188 & -0.8100 & 0.7400 & -0.0003 & 0.0000 & 0.0508 & -0.6751 & 68.6737 \\
\hline$T E D$ & 3188 & 0.0900 & 4.5800 & 0.4756 & 0.3300 & 0.4692 & 3.4313 & 15.8495 \\
\hline$T 103$ & 3188 & -0.5200 & 0.7400 & -0.0003 & 0.0000 & 0.0706 & 0.3092 & 13.0078 \\
\hline \multicolumn{9}{|l|}{$V O L:$} \\
\hline Finan & 3188 & 0.3067 & 4.1602 & 0.9548 & 0.7683 & 0.6553 & 2.5721 & 7.1903 \\
\hline Food & 3188 & 0.2564 & 3.3968 & 0.8610 & 0.7511 & 0.4471 & 2.5141 & 8.0209 \\
\hline Mines & 3188 & 0.6402 & 8.4857 & 1.9823 & 1.7091 & 1.0291 & 2.7008 & 10.7589 \\
\hline Oil & 3188 & 0.5747 & 7.9641 & 1.9979 & 1.6448 & 1.1149 & 2.1610 & 5.9872 \\
\hline Clths & 3188 & 0.3370 & 5.2233 & 1.2396 & 1.0430 & 0.6931 & 2.3908 & 7.1405 \\
\hline Durbl & 3188 & 0.3555 & 4.4174 & 1.1219 & 0.9433 & 0.6076 & 2.4456 & 7.1340 \\
\hline Chems & 3188 & 0.4691 & 5.6315 & 1.3651 & 1.1419 & 0.7860 & 2.5496 & 8.0075 \\
\hline Cnsum & 3188 & 0.3905 & 3.9555 & 1.1191 & 0.9983 & 0.5304 & 2.1705 & 6.2722 \\
\hline Cnstr & 3188 & 0.4539 & 5.8003 & 1.4151 & 1.1799 & 0.8087 & 2.5023 & 7.6474 \\
\hline Steel & 3188 & 0.6599 & 8.2536 & 1.7889 & 1.5135 & 1.0290 & 2.7485 & 9.8194 \\
\hline $\mathrm{FabPr}$ & 3188 & 0.5177 & 5.8957 & 1.3472 & 1.1282 & 0.7519 & 2.6297 & 8.9896 \\
\hline Machn & 3188 & 0.4448 & 4.8894 & 1.1905 & 0.9866 & 0.6591 & 2.4731 & 7.3117 \\
\hline Cars & 3188 & 0.5485 & 7.2541 & 1.4767 & 1.2012 & 0.9363 & 2.9232 & 10.6689 \\
\hline Trans & 3188 & 0.4688 & 4.9477 & 1.2678 & 1.0578 & 0.6867 & 2.2122 & 5.8803 \\
\hline Utils & 3188 & 0.3271 & 4.4226 & 0.9201 & 0.7852 & 0.5360 & 3.4393 & 15.7159 \\
\hline Rtail & 3188 & 0.4036 & 5.2813 & 1.1572 & 0.9674 & 0.6755 & 2.5607 & 8.4903 \\
\hline Other & 3188 & 0.3633 & 4.2826 & 1.0462 & 0.9034 & 0.5734 & 2.3997 & 7.2244 \\
\hline
\end{tabular}

Notes: This table reports the summary statistics for state variables $\mathrm{M}_{\mathrm{t}-1}$. VIX: Implied stock market volatility, as measured by the VIX index. SP: Market performance as measured by S\&P500 returns. TED: A funding liquidity measure of the short-term TED spread, defined as the difference between the three-month LIBOR rate and the three-month Treasury bill rate. T103: The change in term spread, measured as the difference between the long-term (10-year) bond yield and the three-month Treasury bill rate. VOL: sector stock return volatility, which is computed as the 22-day lagged rolling standard deviation of each sector's daily stock return. For each sector, we include that sector's stock return volatility as a state variable. The bottom 17 rows in this table present the summary statistics for each sector's return volatility. SP, TED, and T103 are reported as percentages. The data is comprised of daily observations from 2005-01-04 to 2017-12-29 with 3188 observations for each series. Sectors are defined based on Compustat SIC and CRSP SIC codes (see Appendix D for sectors' definitions). 


\subsubsection{Quantile regression results}

In this section, we discuss the quantile regression estimation results for equation (8). The purpose is to see how the returns from the financial sector and the state variables affect each of the real sub-sectors' tail risk (i.e., the returns at a quantile $q=99 \%$ ).

We estimate equation (8) using the transformed return data with quantile regression method. The estimation period is from 2005-01-04 to 2017-12-29. We report the estimation results for each real sub-sector in Table 4-3.

Column 2 in Table 4-3 reports the size and significance of the regression coefficient

$\hat{\alpha}_{2, q}$ for the financial sector's returns. We can see that the coefficient $\hat{\alpha}_{2, q}$ on the financial sector's returns is significant in each of the 16 sub-sector regressions. This suggests that outcomes in the financial sector are significantly related to outcomes in each real sub-sector at the $99 \%$ quantile. Since at the $99 \%$ quantile outcomes in both the real sub-sector and the financial sector are percentage losses, the significance of $\hat{\alpha}_{2, q}$ means that losses in real subsectors are significantly related to losses in the financial sector. This is consistent with the idea that there is a strong spillover effect from the financial sector to real sub-sectors.

The Mining, Steel, Oil, and Cars sectors have the largest outcomes for $\hat{\alpha}_{2, q}$, indicating losses in these sectors are highly correlated with losses in the financial sector.

Columns 3 to 8 report the size and significance of regression coefficients $\hat{\alpha}_{1, q}$ for the lagged state variables. Among the state variables, VIX, S\&P500 stock returns, and TED spreads are also significant in explaining real sub-sector returns at the $99 \%$ quantile. 
Table 4-3 Coefficients of the CoVaR model

\begin{tabular}{|c|c|c|c|c|c|c|c|c|}
\hline & Intercept & Finan & VIX & SP & $\mathrm{T} 3 \mathrm{M}$ & TED & $\mathrm{T} 103$ & VOL \\
\hline Food & $0.9839 * *$ & $0.6571^{* *}$ & $0.0193 *$ & 0.0055 & 0.066 & $0.265^{* *}$ & $2.3361 *$ & -0.1102 \\
\hline Mines & $2.1218^{* *}$ & $1.407 * *$ & -0.0116 & $-0.393 * *$ & -2.5179 & $3.0906^{* *}$ & 0.1092 & $0.5351^{* *}$ \\
\hline Oil & $1.7073 * *$ & $1.2548^{* *}$ & -0.0864 & -0.1239 & -2.2403 & $2.7575^{* *}$ & 1.7763 & $1.373^{* *}$ \\
\hline Clths & $1.0313^{* *}$ & $0.9156^{* *}$ & 0.0224 & -0.0119 & 1.2289 & 0.3623 & 0.542 & 0.28 \\
\hline Durbl & $0.9519^{* *}$ & $0.9041^{* *}$ & $0.0437 * *$ & -0.0578 & -0.0065 & $0.2435^{* *}$ & 0.1019 & $-0.2919 * *$ \\
\hline Chems & $0.9041^{* *}$ & $1.0927 * *$ & $0.0609 * *$ & -0.0762 & $-3.7983 *$ & $0.6246^{* *}$ & -0.9583 & -0.2108 \\
\hline Cnsum & $0.9656^{* *}$ & $0.8517 * *$ & -0.0074 & -0.0123 & -3.7247 & 0.4222 & -1.7415 & $0.9444 * *$ \\
\hline Cnstr & $1.1965^{* *}$ & $1.2151^{* *}$ & 0.0313 & -0.0458 & -0.5319 & 0.1599 & 0.6841 & -0.0315 \\
\hline Steel & $1.3978^{* *}$ & $1.3925^{* *}$ & 0.014 & $-0.1422 *$ & $-9.9201 *$ & $1.3765^{* *}$ & -1.5984 & $0.3304^{*}$ \\
\hline FabPr & $0.9212^{* *}$ & $1.0541 * *$ & $0.04 *$ & -0.0552 & 0.5427 & 0.2559 & 1.9898 & 0.1749 \\
\hline Machn & $0.9207^{* *}$ & $0.9783 * *$ & $0.0387^{*}$ & -0.0548 & -1.5941 & $0.4123 * *$ & -0.1693 & -0.238 \\
\hline Cars & $0.8916^{* *}$ & $1.2506^{* *}$ & $0.0479 *$ & -0.1716 & -2.2164 & $0.4578 * *$ & 0.8188 & 0.0796 \\
\hline Trans & $0.7939^{* *}$ & $1.0513^{* *}$ & $0.0361 * *$ & -0.0353 & -1.009 & $0.465 * *$ & 0.1759 & -0.0408 \\
\hline Utils & $1.2052 * *$ & $0.5476^{* *}$ & $6 e-04$ & -0.0962 & 2.7761 & $0.7816^{* *}$ & $5.5389 * *$ & 0.3884 \\
\hline Rtail & $1.0579 * *$ & $0.9253^{* *}$ & 0.0064 & 0.0553 & -0.0334 & $0.4749 * *$ & 1.4908 & 0.2456 \\
\hline Other & $0.803^{* *}$ & $0.9094 * *$ & 0.0062 & -0.043 & $-2.9304 *$ & $0.3359 *$ & -0.2564 & 0.3447 \\
\hline
\end{tabular}

Notes: This table presents the size of the coefficient estimates obtained by running a $99 \%$ quantile regression using equation (8). Table rows correspond to real sub-sectors. The estimation period is from 2005-01-04 to 2017-12-29 (3188 observations). Column 2 reports the size of $\hat{\alpha}_{2, q}$, which measures the financial sector's contribution to real sub-sector risk. Columns 3-8 report the size of the $\widehat{\alpha}_{1, q}$ 's, which measure contribution to real sub-sector from the set of lagged state variables $M_{t-1}$. Sectors are defined based on Compustat SIC and CRSP SIC codes (see Appendix D for sectors' definitions).

** and $*$ denote significance at the $1 \%$ and $5 \%$ level respectively.

\subsubsection{Rolling-window estimations}

\subsubsection{Comparing VaR, CoVaR and $\Delta$ CoVaR estimates}

In this section, we compute the daily estimates of one-day-ahead $\mathrm{VaR}_{99 \%}, \mathrm{CoVaR}_{99 \%}$ and $\Delta \mathrm{CoVaR}_{99} \%$ using a 500-day rolling window estimation method ${ }^{28}$.

To implement the rolling window method, for each real sub-sector, we estimate one-day-ahead $\mathrm{VaR}_{99 \%}, \mathrm{CoVaR}_{99 \%}$ and $\Delta \mathrm{CoVaR}_{99 \%}$ on a daily basis for every trading day

\footnotetext{
${ }^{28}$ Consistent with our discussion of equation (1), forward-looking assessments of possible losses and their probabilities - i.e., $\mathrm{VaR}_{99 \%}, \mathrm{CoVaR}_{99 \%}$ and $\Delta \mathrm{CoVaR}_{99 \%}$ - are associated with a forward-looking time period. In our case, all our estimates are one-day-ahead because all of our estimations are based on one-day return data.
} 
in our sample window (2005-01-04 to 2017-12-29) using the previous 500 trading day data.

For example, we first compute the $\mathrm{VaR}_{99 \%}$ for the day 2005-01-04 by using previous 500 trading day data from $2002-12-17$ to $2004-12-31$. Next, we compute the $\mathrm{VaR}_{99} \%$ for the day 2005-01-05 by using data from 2002-12-18 to 2005-01-04. So, the number of increments between successive rolling windows is 1 day. We repeat this process until we compute the $\mathrm{VaR}_{99 \%}$ for the day $2017-12-29$. So we can get $3188 \mathrm{VaR}_{99 \%}$ estimates from 2005-01-04 to 2017-12-29.

Using this method, we can obtain the time series of the one-day-ahead $\mathrm{VaR}_{99 \%}$, $\mathrm{CoVaR}_{99} \%$ and $\Delta \mathrm{CoVaR}_{99} \%$ for each of the real sub-sectors. Tables 4-4, 4-5 and 4-6 report the summary statistics for these time series, respectively.

Table 4-4 Summary statistics of one-day-ahead VaR99\% estimates

\begin{tabular}{llrrrrr}
\hline & \#Obs & Minimum & Maximum & Mean & Median & Stdev \\
\hline Food & 3188 & -0.4127 & 10.6250 & 2.1778 & 1.9500 & 1.1522 \\
Mines & 3188 & -6.4233 & 34.7529 & 5.2531 & 4.6572 & 2.9641 \\
Oil & 3188 & -0.4971 & 29.0644 & 5.2812 & 4.3600 & 3.1788 \\
Clths & 3188 & -3.1505 & 13.4363 & 3.1523 & 2.8146 & 1.6168 \\
Durbl & 3188 & -4.0237 & 12.0408 & 2.8110 & 2.4502 & 1.4186 \\
Chems & 3188 & -0.7742 & 23.5769 & 3.6002 & 3.1334 & 2.0127 \\
Cnsum & 3188 & -0.6787 & 11.4171 & 2.8232 & 2.5055 & 1.2587 \\
Cnstr & 3188 & -2.0540 & 16.0355 & 3.4802 & 3.0620 & 1.7435 \\
Steel & 3188 & -5.3448 & 32.0510 & 4.6618 & 4.0784 & 2.4260 \\
FabPr & 3188 & -1.0099 & 15.5333 & 3.2940 & 2.9521 & 1.5546 \\
Machn & 3188 & -2.6094 & 12.3287 & 2.9640 & 2.6689 & 1.4082 \\
Cars & 3188 & -6.0976 & 14.5274 & 3.8266 & 3.3705 & 1.9443 \\
Trans & 3188 & -0.0394 & 14.3579 & 3.2055 & 2.8744 & 1.5102 \\
Utils & 3188 & -0.3820 & 12.1951 & 2.4601 & 2.0632 & 1.3879 \\
Rtail & 3188 & -1.6944 & 12.6321 & 2.8281 & 2.4254 & 1.4176 \\
Other & 3188 & -1.3027 & 10.3091 & 2.6522 & 2.3661 & 1.2021 \\
\hline
\end{tabular}

Notes: This table reports summary statistics for daily estimates of one-day-ahead $\mathrm{VaR}_{99 \%}$ for each day commencing 2005-01-04 and ending 2017-12-29 for each sector. Each $V_{a R}{ }_{99 \%}$ is estimated by running equations (4) and (5) to obtain equation (6) using data from the 500 trading days preceding each estimate. $\mathrm{VaR}_{99 \%}$ values are reported as percentages. Sectors are defined based on Compustat SIC and CRSP SIC codes (see Appendix D for sectors' definitions). 
Table 4-5 Summary statistics of one-day-ahead CoVaR ${ }_{99 \%}$ estimates

\begin{tabular}{|c|c|c|c|c|c|c|}
\hline & $\# \mathrm{Obs}$ & Minimum & Maximum & Mean & Median & Stdev \\
\hline Food & 3188 & -0.0987 & 14.0085 & 2.9876 & 2.8259 & 1.1713 \\
\hline Mines & 3188 & 2.0720 & 42.4837 & 7.4555 & 6.7866 & 3.4216 \\
\hline Oil & 3188 & 0.7551 & 30.8528 & 7.0823 & 6.2392 & 3.4533 \\
\hline Clths & 3188 & -1.8031 & 13.4239 & 4.0200 & 3.6589 & 1.6077 \\
\hline Durbl & 3188 & 0.9199 & 14.6802 & 3.7333 & 3.3820 & 1.4454 \\
\hline Chems & 3188 & 0.1098 & 20.7090 & 4.6184 & 4.2455 & 1.8724 \\
\hline Cnsum & 3188 & -0.2485 & 16.6168 & 4.1213 & 3.7788 & 1.6246 \\
\hline Cnstr & 3188 & -0.1700 & 21.3919 & 4.7622 & 4.5099 & 1.9003 \\
\hline Steel & 3188 & 1.3157 & 29.6277 & 6.3491 & 5.6591 & 2.5798 \\
\hline FabPr & 3188 & 0.3950 & 18.0941 & 4.5086 & 4.1038 & 1.7592 \\
\hline Machn & 3188 & 0.2039 & 15.6721 & 3.9839 & 3.6610 & 1.4679 \\
\hline Cars & 3188 & 0.1611 & 22.3234 & 5.1689 & 4.5040 & 2.3556 \\
\hline Trans & 3188 & 0.6067 & 17.8075 & 4.3100 & 3.9944 & 1.7341 \\
\hline Utils & 3188 & 0.0179 & 11.6507 & 3.1972 & 2.8470 & 1.3179 \\
\hline Rtail & 3188 & -1.8254 & 16.4912 & 3.8573 & 3.4613 & 1.7356 \\
\hline Other & 3188 & -2.3213 & 15.2056 & 3.5445 & 3.2988 & 1.3830 \\
\hline
\end{tabular}

Notes: This table reports summary statistics for daily estimates of one-day-ahead $\mathrm{CoVaR}_{99 \%}$ for each day commencing 2005-01-04 and ending 2017-12-29 for each sector. Each $\mathrm{CoVaR}_{99 \%}$ is estimated by running equations (8) and (9) to obtain equation (10) using data from the 500 trading days preceding each estimate. $\mathrm{CoVaR}_{99} \%$ values are reported as percentages. Sectors are defined based on Compustat SIC and CRSP SIC codes (see Appendix D for sectors' definitions).

Table 4-6 Summary statistics of one-day-ahead $\Delta$ CoVaR99\% estimates

\begin{tabular}{llrrrrr}
\hline & \#Obs & Minimum & Maximum & Mean & Median & Stdev \\
\hline Food & 3188 & -0.7138 & 6.5509 & 1.7555 & 1.5548 & 0.8666 \\
Mines & 3188 & -0.7372 & 12.7824 & 3.3058 & 3.0156 & 1.5479 \\
Oil & 3188 & -0.7844 & 11.7131 & 3.0052 & 2.9661 & 1.5073 \\
Clths & 3188 & -1.1538 & 9.0193 & 2.1816 & 1.9387 & 1.0250 \\
Durbl & 3188 & -0.5860 & 9.0902 & 2.1773 & 1.9124 & 1.0991 \\
Chems & 3188 & -1.4017 & 10.1987 & 2.7626 & 2.5087 & 1.2568 \\
Cnsum & 3188 & -1.5149 & 8.1967 & 2.3194 & 2.1295 & 1.0083 \\
Cnstr & 3188 & -1.3228 & 11.3652 & 2.9973 & 2.7031 & 1.3949 \\
Steel & 3188 & -0.8172 & 12.3232 & 3.4497 & 3.1059 & 1.5656 \\
FabPr & 3188 & -0.6797 & 10.2689 & 2.6348 & 2.3813 & 1.2711 \\
Machn & 3188 & -0.5091 & 8.8407 & 2.5381 & 2.2786 & 1.0760 \\
Cars & 3188 & -0.6436 & 16.7237 & 3.1610 & 2.7246 & 1.8088 \\
Trans & 3188 & -0.9520 & 11.6385 & 2.7565 & 2.4914 & 1.3354 \\
Utils & 3188 & -2.2058 & 7.0580 & 1.5004 & 1.3520 & 0.8494 \\
Rtail & 3188 & -1.3472 & 11.0440 & 2.2952 & 2.0092 & 1.2451 \\
Other & 3188 & -1.6377 & 8.7433 & 2.3798 & 2.1530 & 1.0123 \\
\hline Notes: This & & & & & &
\end{tabular}

Notes: This table reports summary statistics for daily estimates of one-day-ahead $\Delta \mathrm{CoVaR}_{99 \%}$ for each day commencing 2005-01-04 and ending 2017-12-29 for each sector. Each $\Delta \mathrm{CoVaR}_{99 \%}$ is estimated by running equation (11) using data from the 500 trading days preceding each estimate. $\Delta \mathrm{CoVaR}_{99} \%$ values are reported as percentages. Sectors are defined based on Compustat SIC and CRSP SIC codes (see Appendix D for sectors' definitions). 
Next, we compare the riskiness based on the risk estimation results using the above risk indicators (i.e., $\mathrm{VaR}_{99 \%}, \mathrm{CoVaR}_{99 \%}$ and $\Delta \mathrm{CoVaR}_{99 \%}$ ). We aim at exploring which real sub-sectors appear to be riskier than others.

Table 4-7 lists the real sub-sectors ranked using the mean values of the daily estimates of $\mathrm{VaR}_{99 \%}, \mathrm{CoVaR}_{99 \%}$ and $\Delta \mathrm{CoVaR}_{99 \%}$. The first ranked are the riskiest and the last ranked are the least risky. The mean values of $\mathrm{VaR}_{99 \%}, \mathrm{CoVaR}_{99 \%}$ and $\Delta \mathrm{CoVaR}_{99 \%}$ are obtained from Column 5 in Table 4-4, 4-5, and 4-6. In addition to present the rankings based on $\mathrm{VaR}_{99 \%}, \mathrm{CoVaR}_{99 \%}$ and $\Delta \mathrm{CoVaR}_{99 \%}$, we also present the ranking based on Return $99 \%$, which is defined as the $99 \%$ quantile of the return series ${ }^{29}$.

${ }^{29}$ Return $_{99 \%}$ is obtained by finding the $99 \%$ quantile of the return series. Over the period commencing 2005-01-04 and ending 2017-12-29, each day we find the 99\% return quantile using the previous 500 trading day data. Then we obtain the mean values of the Return ${ }_{99 \%}$ data series, and we rank the riskiness of the sectors based on their mean values of Return ${ }_{99 \%}$. The $99 \%$ return quantile differs significantly from $\mathrm{VaR}_{99 \%}$ because the former is simply the raw cut-off return level determined without conditioning on any state variables as in equation (4). 
Table 4-7 Rankings of real sub-sectors

\begin{tabular}{|c|c|c|c|c|c|c|c|c|}
\hline \multirow[t]{2}{*}{ Rank } & \multicolumn{2}{|c|}{ Return99\% } & \multicolumn{2}{|c|}{$\mathrm{VaR}_{99 \%}$} & \multicolumn{2}{|c|}{$\mathrm{CoVaR}_{99 \%}$} & \multicolumn{2}{|c|}{$\Delta \mathrm{CoVaR} 99 \%$} \\
\hline & Sector & Value & Sector & Value & Sector & Value & Sector & Value \\
\hline 1 & Mines & 6.1637 & Oil & 5.2812 & Mines & 7.4555 & Steel & 3.4497 \\
\hline 2 & Oil & 5.8553 & Mines & 5.2531 & Oil & 7.0823 & Mines & 3.3058 \\
\hline 3 & Steel & 5.4346 & Steel & 4.6618 & Steel & 6.3491 & Cars & 3.1610 \\
\hline 4 & Cars & 4.4680 & Cars & 3.8266 & Cars & 5.1689 & Oil & 3.0052 \\
\hline 5 & Cnstr & 4.2167 & Chems & 3.6002 & Cnstr & 4.7622 & Cnstr & 2.9973 \\
\hline 6 & Chems & 4.1591 & Cnstr & 3.4802 & Chems & 4.6184 & Chems & 2.7626 \\
\hline 7 & FabPr & 4.0117 & $\mathrm{FabPr}$ & 3.2940 & FabPr & 4.5086 & Trans & 2.7565 \\
\hline 8 & Trans & 3.7552 & Trans & 3.2055 & Trans & 4.3100 & FabPr & 2.6348 \\
\hline 9 & Machn & 3.6610 & Clths & 3.1523 & Cnsum & 4.1213 & Machn & 2.5381 \\
\hline 10 & Clths & 3.5671 & Machn & 2.9640 & Clths & 4.0200 & Other & 2.3798 \\
\hline 11 & Cnsum & 3.4466 & Rtail & 2.8281 & Machn & 3.9839 & Cnsum & 2.3194 \\
\hline 12 & Other & 3.3590 & Cnsum & 2.8232 & Rtail & 3.8573 & Rtail & 2.2952 \\
\hline 13 & Rtail & 3.2728 & Durbl & 2.8110 & Durbl & 3.7333 & Clths & 2.1816 \\
\hline 14 & Durbl & 3.2101 & Other & 2.6522 & Other & 3.5445 & Durbl & 2.1773 \\
\hline 15 & Utils & 2.7474 & Utils & 2.4601 & Utils & 3.1972 & Food & 1.7555 \\
\hline 16 & Food & 2.6736 & Food & 2.1778 & Food & 2.9876 & Utils & 1.5004 \\
\hline
\end{tabular}

Notes: This table lists the real sub-sectors ranked from most risky to least risky according to the mean value of the daily estimates of Return ${ }_{99 \%}, \mathrm{VaR}_{99 \%}, \mathrm{CoVaR}_{99 \%}$ and $\Delta \mathrm{CoVaR}_{99 \%}$ with the daily estimates determined using a 500-day rolling window method for the period 2005-01-04 to 2017-12-29. "Sector" is defined based on Compustat SIC and CRSP SIC codes (see Appendix D for sectors' definitions). "Value" means the mean values of the risk indicators.

Table 4-7 shows that the Mining, Steel, Oil, and Cars sectors are ranked among the top four sectors using either risk indicator. Recall that in Section 4.4.2, we find that these four sectors have the largest outcomes for $\hat{\alpha}_{2, q}$, indicating losses in these sectors are highly correlated with losses in the financial sector.

Table 4-7 also shows that the rankings based on $\mathrm{VaR}_{99 \%}$ and $\mathrm{CoVaR}_{99 \%}$ are similar, while the rankings based on $\Delta \mathrm{CoVaR}_{99 \%}$ are a little different. This result can also be observed by the scatterplots in Figure 4-3, which shows that there is a strong correlation between $\mathrm{VaR}_{99 \%}$ and $\mathrm{CoVaR}_{99 \%}$, whereas there is a weaker correlation between $\mathrm{VaR}_{99 \%}$ and $\Delta \mathrm{CoVaR}_{99 \%}$. 
Figure 4-3 The relationship between CoVaR99\% and VaR99\%, and between $\Delta \mathrm{CoVaR}_{99 \%}$ and VaR99\% Panel (a)
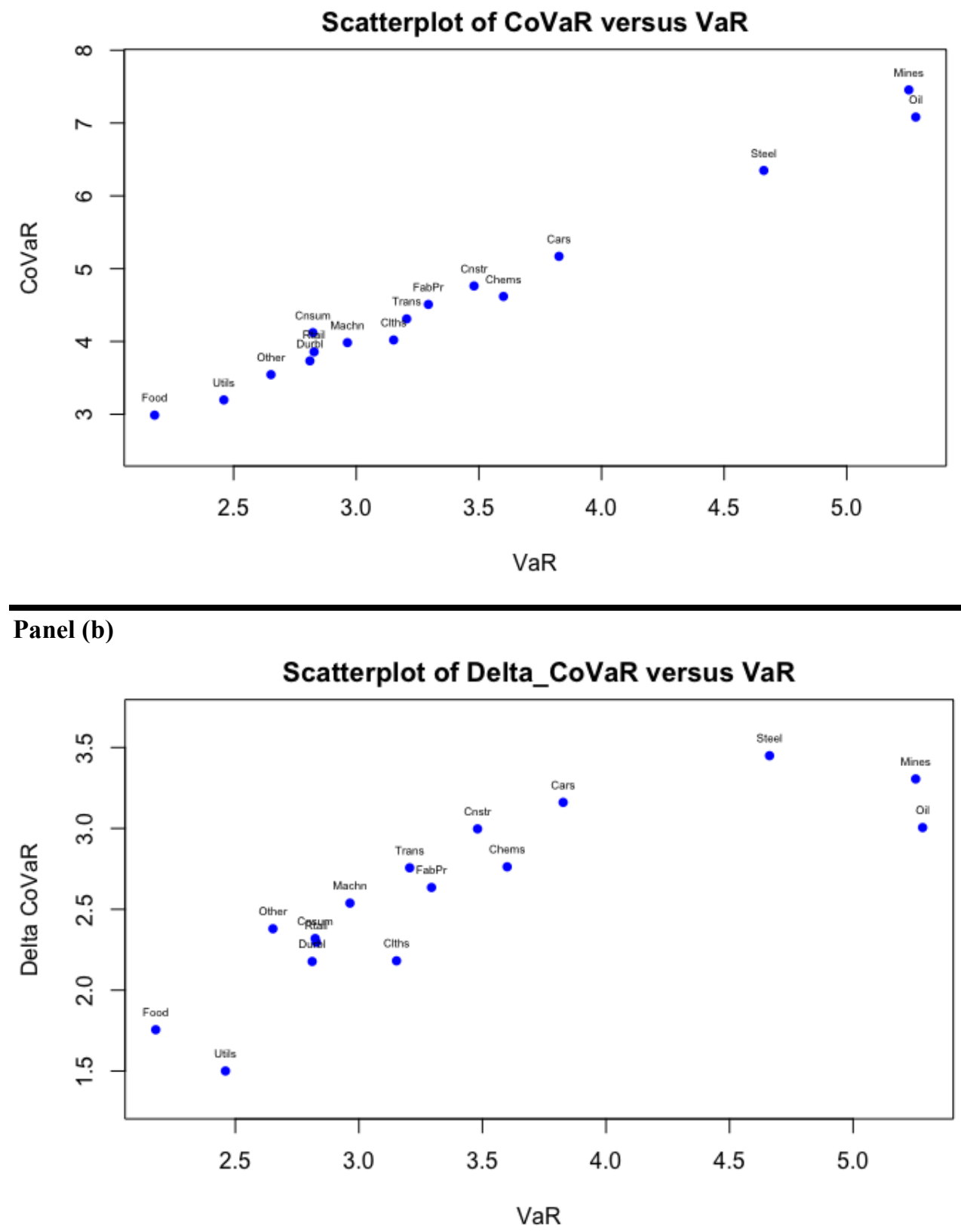

Notes: The scatterplot in Panel (a) displays the relationship between the mean of $\mathrm{VaR}_{99 \%}$ and $\mathrm{CoVaR}_{99 \%}$ for real sub-sectors estimated from 2005-01-04 to 2017-12-29 using 500-day rolling window data. The scatterplot in Panel (b) displays the relationship between the mean of $\mathrm{VaR}_{99 \%}$ and $\Delta \mathrm{CoVaR}_{99 \%}$ (estimated from 2005-01-04 to 2017-12-29 using 500-day rolling window data) for each real sub-sector. Sectors are defined based on Compustat SIC and CRSP SIC codes (see Appendix D for sectors' definitions). 
The way in which $\mathrm{VaR}_{99 \%}, \mathrm{CoVaR}_{99 \%}$ and $\Delta \mathrm{CoVaR}_{99 \%}$, are qualitatively different can be seen in the plot of the time series of the daily estimates for the real sub-sectors. Figure 4-4 presents the time-series plots the daily estimates of $\mathrm{VaR}_{99 \%}, \mathrm{CoVaR}_{99 \%}$, and $\Delta \mathrm{CoVaR}_{99 \%}$ for the Mining sector, one of the higher risk sectors.

In Figure 4-4, the transformed realized return series is plotted in red, $\mathrm{VaR}_{99 \%}$ is plotted in blue, $\mathrm{CoVaR} 99 \%$ is plotted in green, and $\Delta \mathrm{CoVaR}_{99 \%}$ is plotted in purple.

Figure 4-4 Mining sector realized losses and daily estimates of $\operatorname{VaR}_{99 \%}, \mathrm{CoVaR}_{99 \%} \Delta \mathrm{CoVaR}_{99 \%}$

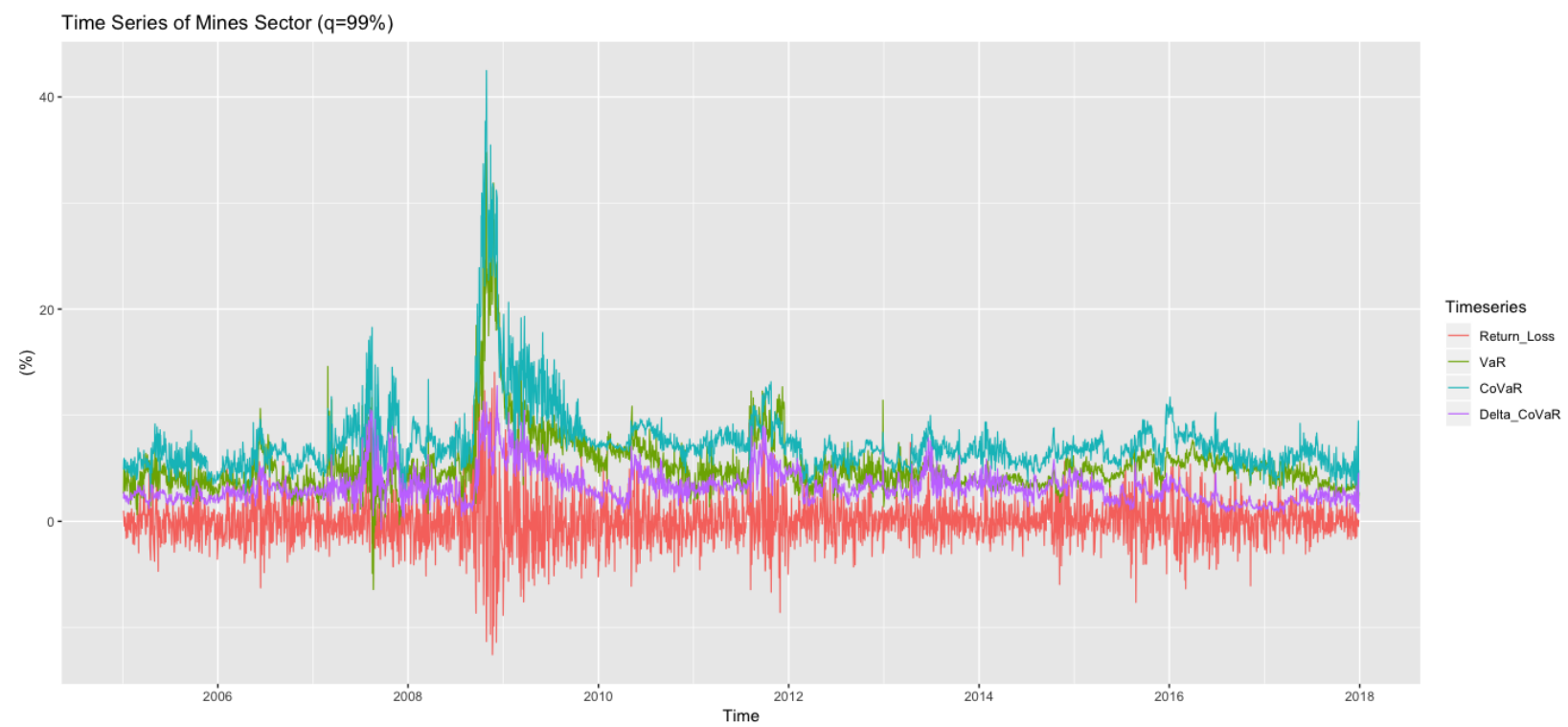

Notes: This figure displays a plot of the daily estimates of one-day-ahead $\mathrm{VaR}_{99 \%}, \mathrm{CoVaR}_{99 \%}$ and $\Delta \mathrm{CoVaR}_{99 \%}$ and the negative or realized returns for the Mining sector for the period 2005-01-04 to 201712-29. Adjusted raw returns denoted $r_{t}$ from equation (12) are plotted in red, $\mathrm{VaR}_{99 \%}$ is plotted in blue line, $\mathrm{CoVaR}_{99 \%}$ is plotted in green and $\Delta \mathrm{CoVaR}_{99 \%}$ is plotted in purple, all across time. We make our estimates using data from the 500 trading days preceding each estimate.

Several things can be observed from Figure 4-4. First, both $\mathrm{VaR}_{99 \%}$ and $\mathrm{CoVaR}_{99 \%}$ react sensitively to underlying returns and show a high level of risk during the 2008-2009 crisis period. Second, CoVaR $99 \%$ is consistently higher than $\mathrm{VaR}_{99 \%}$ over time, suggesting that CoVaR is a more conservative risk measure than VaR. This finding is confirmed by 
the summary statistics from Tables 4-4 and 4-5. In addition, compared to $\mathrm{VaR}_{99 \%}, \mathrm{CoV}_{\mathrm{V}} \mathrm{R}_{99 \%}$ shows greater volatility in the pre-crisis period (mid-2007 to mid-2008 period). This characteristic is observed in all 16 real sub-sectors (see Appendix E).

The purple colored line in Figure $4-4$ is the plot of the $\Delta \mathrm{CoVaR}_{99 \%}$ time series. Interestingly, while $\Delta \mathrm{CoVaR}_{99 \%}$ is at a relatively high level and is quite volatile before 2008Q4, it drops suddenly to a very low level at the beginning of 2008Q4. Recall that $\Delta \mathrm{CoVaR}$ is interpreted as the change in $\mathrm{CoVaR}$ for a real sub-sector when the financial sector shifts from a normal state to a stressed state. A large decrease in $\Delta \mathrm{CoVaR}$ indicates that the real sub-sector's CoVaR has ceased to respond much to a change in the financial sector's risk state. The $\Delta \mathrm{CoVaR}_{99 \%}$ pattern in Figure 4-4 indicates that before the financial crisis outbreak in October 2008, the risk level in the Mining sector was very sensitive to changes in the risk level in the financial sector, but after the outbreak, this risk sensitivity attenuated.

One can observe similar effects in Figure 4-5. It presents a plot of daily estimates of coefficient $\hat{\alpha}_{2, q}$ from equation (10) through time for the Mining sector, and the contemporaneous estimate of the standard deviation of $\hat{\alpha}_{2, q}$. As discussed in Section 4.3.2, $\hat{\alpha}_{2, q}$ captures the spillover effect to real sub-sectors of return losses in the financial sector. The plot of $\hat{\alpha}_{2, q}$ in Figure 4-5 shows that the spillover effect from the financial sector reached a maximum (within our sample period) before the 2008 financial crisis and dramatically decreased when the financial crisis started. A possible explanation can be that once the financial crisis broke out, financial institutions froze lending to firms, so the Mining sector responded by decreasing its financial dependence on the financial sector, and this rendered the Mining sector relatively immune to risk emanating from the financial 
sector. In later months, the financial sector dependence resumed as the financial sector recovered and the Mining sector came to be seen as relying on it again.

\section{Figure 4-5 Time-varying coefficients and error bands for the Mining sector}

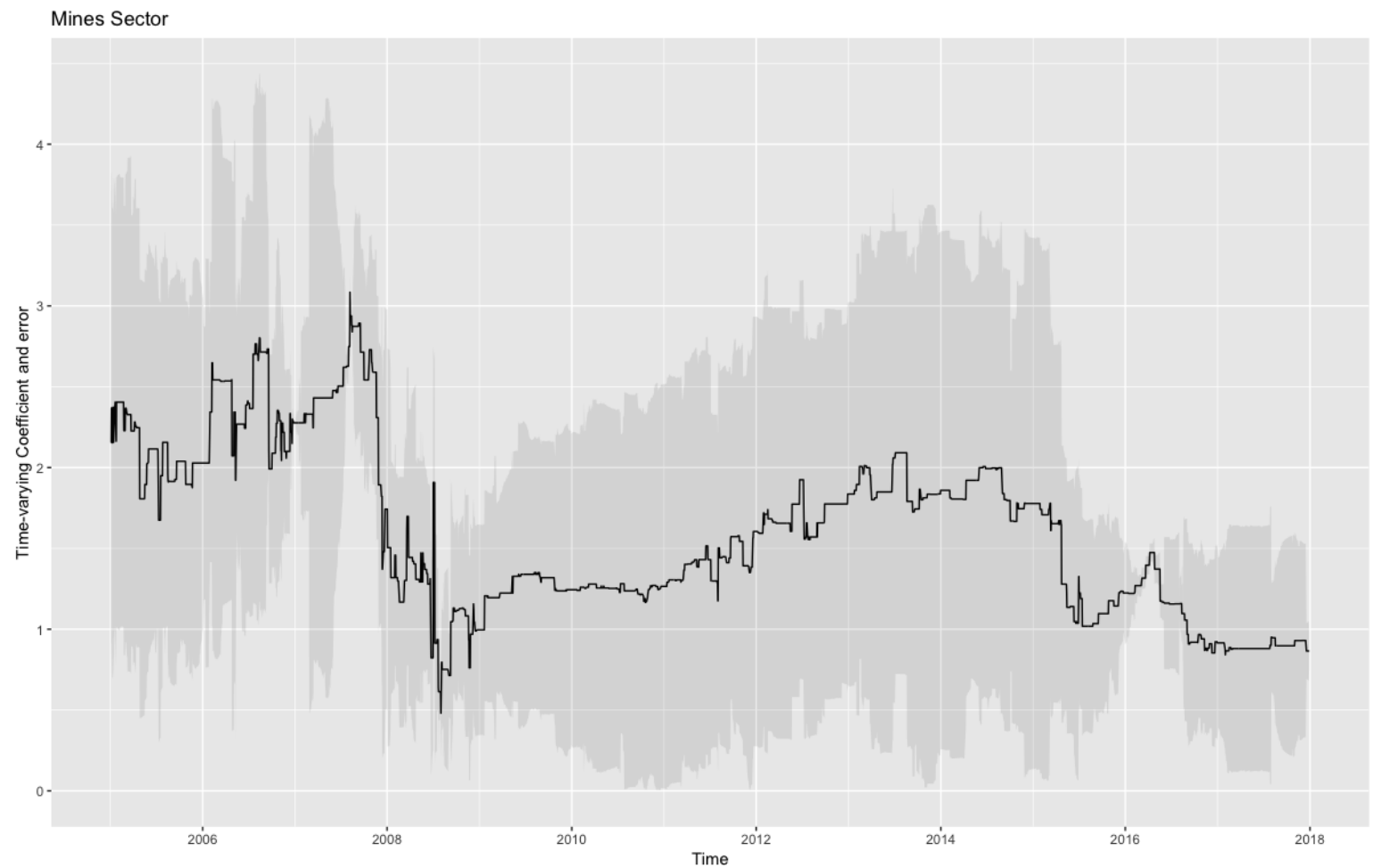

Notes: This figure presents a plot of the estimated daily coefficient and error band of $\hat{\alpha}_{2, q}$ in equation (10). In equation (10), $\hat{\alpha}_{2, q}$ measures the contribution to Mining sector risk from the financial sector for the $99 \%$ quantile. For each day commencing 2005-01-04 and ending 2017-12-29, we use data from the 500 trading days preceding each estimate to run equations (8) and (9) to obtain equation (10). We record the coefficient $\hat{\alpha}_{2, q}$ and the standard deviation of $\hat{\alpha}_{2, q}$.

Appendix F presents the plots of daily estimates of coefficient $\alpha_{2, q}$ from equation (9) through time and the contemporaneous estimate of the standard deviation of $\alpha_{2, q}$ for all 16 real sub-sectors. For most of the sectors, the coefficient $\alpha_{2, q}$ declines at the beginning of 2008 Q2. After the crisis, it returns to, or even exceeds the pre-crisis level, suggesting that the real sub-sectors eventually recover their dependence on, or come to be seen as dependent on the financial sector once again. 


\subsubsection{Back-testing VaR and CoVaR}

In this section, we assess the forecast accuracy of the VaR and CoVaR models. An important empirical question is whether risk, as proxied by VaR (or CoVaR), is a useful indicator of the size and frequency of the future outcomes that might transpire. We use back-testing to examine this matter.

Back-testing involves making periodic (in our case, daily) ex-ante estimates of VaR (or CoVaR) using a particular model, and then observing ex-post returns to see whether the estimated $\mathrm{VaR}$ (or CoVaR) is exceeded more or less frequently than the model predicts (Danielsson, 2011). Figure 4-4 shows that at some points in time, realized losses exceeded estimated VaR (or CoVaR). Whenever realized losses exceed VaR (or CoVaR), a violation is said to have occurred. For back-testing with $q=99 \%$, we would expect to observe a VaR violation frequency of $1 \%$ in the testing windows (i.e., the days on which we intend to make comparisons). If violations are observed with a frequency of greater than $1 \%$, the VaR model is said to underestimate risk at the $99 \%$ level. If violations are observed with a frequency of less than $1 \%$, the VaR model is said to overestimate risk at the $99 \%$ level.

In addition, any two violations should be independent of each other. A violation observed today should not convey information about the likelihood of observing a violation tomorrow; one should reject a VaR model if violations under the model exhibit clustering in time.

Christoffersen (2012) suggests that the sequence of violations should be distributed independently over time as a Bernoulli variable. Formal tests of violations include the Bernoulli Coverage test and Independence of Violations test. If the null hypothesis in the Bernoulli Coverage test is rejected by the data, the VaR model should also be rejected 
because this result implies that the frequency of violations is significantly different from the expected frequency of violations. If the null hypothesis in the Independence of Violations test is rejected by the data, again, the VaR model should also be rejected because this result implies there is clustering of violations.

Similar to the rolling window estimation steps in Section 4.4.3.1, we use the 500day rolling window data to obtain daily estimates of one-day-ahead $\mathrm{VaR}_{99 \%}$ and $\mathrm{CoVaR}_{99 \%}$. Next, we compare the estimated one-day-ahead $\mathrm{VaR}_{99 \%}$ and $\mathrm{CoVaR}_{99 \%}$ to the realized returns on the next day. We record the violations when realized losses exceed $\mathrm{VaR}_{99 \%}$ (or CoVaR99\%). Then, following Christoffersen (2012), we perform the Bernoulli Coverage test and the Independence of Violations test, respectively, on the sequences of violations for each real sub-sector. Because our sample window includes the financial crisis period, which was a period of high returns volatility, we conducted tests separately for two periods: Period A - the crisis period (2008-06-02 to 2009-06-01); and, Period B - the period before and after the crisis period (2005-01-04 to 2008-06-01, and 2009-06-02 to 2017-12-29). The results are reported in Table 4-8. 
Table 4-8 Back-testing - Bernoulli Coverage Test and Independence of Violations Test

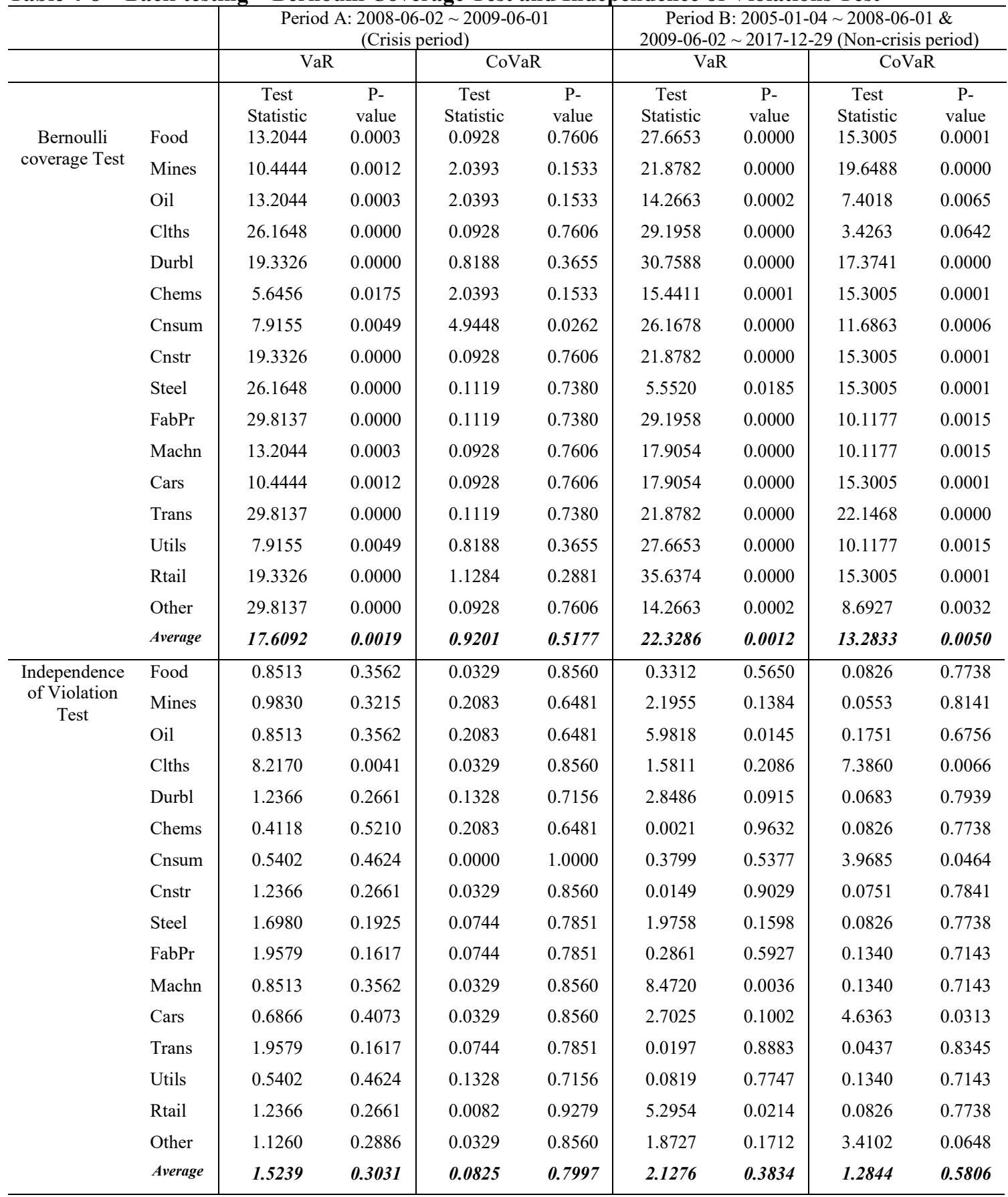

Notes: This table reports the results of back-testing VaR and CoVaR for violations for two periods. Period A: the crisis period (2008-06-02 to 2009-06-01) and Period B: the non-crisis period (2005-01-04 to 2008-0601, and 2009-06-02 to 2017-12-29). The upper panel reports the Bernoulli Coverage test statistics and the corresponding P-values. The lower panel reports the Independence of Violations test statistics and the corresponding P-values. The last row of each panel reports the average test statistics and P-values of all 16 real sub-sectors. Sectors are defined based on Compustat SIC and CRSP SIC codes (see Appendix D for sectors' definitions). 
The upper panel of Table 4-8 reports the Bernoulli Coverage test statistics and the corresponding P-values for each sector. The lower panel of Table 4-8 reports the Independence of Violations test statistics and the corresponding P-values for each sector. P-values larger than 0.05 - neither the null hypothesis nor the VaR/CoVaR model should be rejected - are evident in the table. The last row in each panel reports the average test statistics and P-values for all 16 real sub-sectors.

The test results show that both models performed well in both periods in the Independence of Violations test. In terms of the Bernoulli Coverage test, the CoVaR model performed better than VaR model during the crisis period; in fact, the former was not rejected by the test in any of the real sub-sectors at the $1 \%$ level and in only one real subsector at the 5\% level whereas the latter was rejected in every real sub-sector at the $5 \%$ level and in all but one at the $1 \%$ level. This suggests that the CoVaR model was a more reliable risk measure than the VaR model during the crisis period.

Neither model performed well in the Bernoulli Coverage test for the non-crisis period. VaR was rejected in all real sub-sectors at the $5 \%$ level and in all but one at the $1 \%$ level. CoVaR was rejected all but one real sub-sector, with the rejection being at both the $5 \%$ level and $1 \%$ levels. This result is consistent with the infrequent violations seen in Figure 4-4. There, the values for $\mathrm{VaR}$ and $\mathrm{CoVaR}$ are generally so large that there are very few violations in that window of time. Our results suggest that, outside of crisis periods, both models appear to generate conservative estimates of boundary losses that are unlikely to be violated. 


\subsubsection{Time path analysis}

In this section, we investigate the time path of each real sub-sector's reaction to shocks originating from the financial sector using IRFs. The analysis shows how quickly each real sub-sector responds and how persistent the response is.

To estimate the IRFs, we need to estimate the vector autoregressive model ("VAR"), which is often used to model how different time series are correlated with each other.

Let $Z_{t}=\left(\begin{array}{l}r_{t}^{1} \\ r_{t}^{2}\end{array}\right)$ be the vector process comprised of two return time series. $r_{t}^{1}$ denotes the returns for a real sub-sector that is affected by the risk from the financial sector, and $r_{t}^{2}$ denotes returns for the financial sector. Then, the VAR(p) model is:

$$
Z_{t}=\Gamma_{0}+\Gamma_{1} Z_{t-1}+\cdots+\Gamma_{p} Z_{t-p}+a_{t}
$$

where $\Gamma_{0}=\left(\begin{array}{c}\Gamma_{0}^{1} \\ \Gamma_{0}^{2}\end{array}\right)$ is a constant vector, and $\Gamma_{1}, \cdots, \Gamma_{p}$ are $2 \times 2$ matrices. The innovation vector (residual vector) is $a_{t}=\left(\begin{array}{l}\mathrm{a}_{t}^{1} \\ \mathrm{a}_{t}^{2}\end{array}\right)$ comprised of independent random variables following $N(0, \Sigma)$.

The parameters in the $\operatorname{VAR}(\mathrm{p})$ model are calibrated with three steps. First, the optimal order $p$ (i.e., the number of optimal lags) is selected using the Akaike Information Criterion ("AIC"). Second, once $p$ is determined, $\Gamma_{0}, \Gamma_{1}, \cdots, \Gamma_{p}$ are determined by OLS. Lastly, the standard deviation and correlation of the residuals determine matrix $\Sigma$.

After identifying the VAR(p) model, we can examine the spillover effect of financial sector shocks to real sub-sectors using IRFs. 
Equation (13) of VAR(p) can be rewritten as:

$$
Z_{t}=\mu+a_{t}+\psi_{1} a_{t-1}+\psi_{2} a_{t-2}+\cdots
$$

In equation (14), if $a_{t}$ increases by one unit (i.e., one unit of positive shock), $Z_{t}$ responds to $a_{t}$ by increasing one unit; $Z_{t+1}$ respond to $a_{t}$ by increasing $\psi_{1}$ units; $Z_{t+2}$ responds to $a_{t}$ by increasing $\psi_{2}$ units... Therefore, $\psi_{i}$ determines how $Z_{t}$ responds to a shock in $a_{t-1}$ (similarly, how $Z_{t+i}$ responds to shock $a_{t}$ ). So, $\Psi_{i}$ is called the IRF.

One issue is that $\psi_{i}$ measures the responses to $a_{t}$ (reduced form shock), which may possess non-zero concurrent cross-correlation (Tsay, 2010). To examine responses to orthogonalized shocks (via Cholesky decomposition), VAR(p) should be transformed to a structural form. For methods, see Sims (1980), and Pesaran and Shin (1998).

We examine the response of each real sub-sector's returns to a one standard error positive shock to the financial sector's returns ${ }^{30}$. The plots of IRFs tell the size of the response and how persistent the response is. If each real sub-sector is closely related to the financial sector and shocks are persistent, we would expect reactions to the initial shock to last for a longer period.

Appendix G presents plots of each real sub-sector's IRF. The size of the shock of each series is 1 standard deviation. The time series period ranges from 2005-01-04 to 201712-29. For each financial sector/real sub-sector system, the VAR lag selections are based

\footnotetext{
${ }^{30}$ One standard error positive shock means the size of the shock is one standard deviation unit of the residual term $a_{t}$.
} 
on the Akaike criterion (AIC). The Cholesky ordering is such that the financial sector's return series comes first, and the shocked real sub-sector's return series comes second.

All IRFs shows that the real sub-sectors' stock returns respond to shocks originating from the financial sector's stock returns immediately: an impulse (shock) from financial sector's stock returns to each real sub-sector's stock returns at day zero has large effects the next day, but the effects become smaller and smaller as the time passes. The effects disappear within 7 to 15 trading days.

\subsection{Conclusions}

Based on known connections between the financial sector and real sub-sectors, we postulated that a real sub-sector's tail risk would increase when the financial sector shifts from a normal state to a stressed state. Using the CoVaR approach developed by Adrian and Brunnermeier (2016), we quantify the size of risk spillovers from the financial sector to each real sub-sector. The quantile regression results presented in Section 4.4.2 present empirical support for the idea that We define CoVaR as the Value-at-Risk from the financial sector contributes significantly to each in a real sub-sector's CoVaR.

The results presented in Section 4.4.3.1 show that both $\mathrm{VaR}_{99 \%}$ and $\mathrm{CoVaR}_{99 \%}$ appear to be sensitive to changes in the underlying return loss process and show a high level of risk during the $2008-2009$ crisis period. $\mathrm{CoVaR}_{99 \%}$ is consistently higher than $\mathrm{VaR}_{99 \%}$ over time, suggesting that $\mathrm{CoVaR}$ can be used as a more conservative risk measure than VaR. Compared to $\mathrm{VaR}_{99 \%}$, $\mathrm{CoVaR}_{99 \%}$ shows greater volatility in the pre-crisis period (mid-2007 to mid-2008 period) with the attenuation possibly because some sub-sectors reduced their dependence conditional on the financial sector once the crisis had 
commenced. The spillover effect from the financial sector to real sub-sector reached the highest levels in our sample period before the 2008 financial crisis and dramatically decreased once the financial crisis had started. Our analysis also shows that there is a strong correlation between $\mathrm{VaR}_{99 \%}$ and $\mathrm{CoVaR}_{99 \%}$, and there is a weaker correlation between $\mathrm{VaR}_{99 \%}$ and $\Delta \mathrm{CoVaR}_{99 \%}$ being in a stressed state.

Section 4.4.3.2 reports the results of the back-testing both the VaR and CoVaR models. They show that the unconditional VaR model did not perform as well as the CoVaR model during the financial crisis period in the Bernoulli Coverage test and that neither performed well in this test during the period after the financial crisis where both models tended to overstate the risk. The contribution of the CoVaR model appears to be that it can be a more reliable indicator of risk during very volatile market periods, e.g., the crisis period. Our results also suggest that, outside of crisis periods, both models appear to generate conservative estimates of boundary losses that are unlikely to be violated.

Section 4.4.4 reports the results of using IRFs to examine the response of real subsectors to shocks in the financial system. Our results show that the real sub-sectors' stock returns respond to shocks originating from the financial sector's stock returns immediately (in one day) and that the effects attenuate over the ensuing two weeks.

The CoVaR approach is useful in examining the spillover effects from one institution to another or a group of institutions. Many studies have adopted this approach to examine the spillover effects within the financial sector. This study extends the application of this approach to an examination of the cross-industry spillover effect, specifically from the financial sector to real sub-sectors. In terms of the future work to extend this study, first, the influence direction between the financial sector and other real 
sub-sectors could be either-way. For example, when the real-estate industry is in distress, the banking sector will probably suffer from increased default rates in housing mortgage loans. Future study may extend this study by considering the factor that the other sectors' risks will also affect the financial sectors' performance. Second, this study has not addressed the mechanisms underlying the spillovers from the financial sector to other sectors. For some real sub-sectors, the spillover effect could be dominated by credit supply shocks whereas for others it could be dominated by product demand shocks or even shocks not identified in this study. To understand the underlying mechanisms, future studies should consider using more detailed firm-level or industry-level information to explore the relationship between firm or industry characteristics and spillover effects.

\section{References}

Adams, Z., Füss, R., \& Gropp, R. (2014). Spillover effects among financial institutions: A state-dependent sensitivity value-at-risk approach. Journal of Financial and Quantitative Analysis, 49(3), 575-598.

Adrian, T., \& Brunnermeier, M. K. (2016). CoVaR. American Economic Review, 106(7), 1705-41.

Baig, T., \& Goldfajn, I. (1999). Financial market contagion in the Asian crisis. IMF staff papers, 46(2), 167195.

Bekaert, G., \& Harvey, C. R. (2003). Market integration and contagion (No. w9510). National Bureau of Economic Research.

Bernanke, B. S., \& Blinder, A. S. (1988). Credit, Money, And Aggregate Demand. The American Economic Review, 78(2), 435.

Birol, F (2009). The Impact of the Financial and Economic Crisis on Global Energy Investments. Energy, Policies and Technologies for Sustainable Economies, 10th IAEE European Conference, 2009. International Association for Energy Economics.

Braun, M., \& Larrain, B. (2005). Finance and the business cycle: international, inter-industry evidence. The Journal of Finance, 60(3), 1097-1128.

Calomiris, C. W., Love, I., \& Pería, M. S. M. (2012). Stock returns' sensitivities to crisis shocks: Evidence from developed and emerging markets. Journal of International Money and Finance, 31(4), 743-765.

Castro, C., \& Ferrari, S. (2014). Measuring and testing for the systemically important financial institutions. Journal of Empirical Finance, 25, 1-14. 
Chan-Lau, J. A., Mathieson, D. J., \& Yao, J. Y. (2004). Extreme contagion in equity markets. IMF staff papers, 51(2), 386-408.

Chava, S., \& Purnanandam, A. (2011). The effect of banking crisis on bank-dependent borrowers. Journal of Financial Economics, 99(1), 116-135.

Christoffersen, P. F. (2012). Elements of financial risk management. Academic Press.

Claessens, S., \& Forbes, K. (2004, November). International financial contagion: The theory, evidence and policy implications. In Conference "The IMF's role in emerging market economies: Reassessing the adequacy of its resources", Amsterdam.

Daníelsson, J. (2011). Financial risk forecasting: the theory and practice of forecasting market risk with implementation in R and Matlab (Vol. 588). John Wiley \& Sons.

Dees, S., Mauro, F. D., Pesaran, M. H., \& Smith, L. V. (2007). Exploring the international linkages of the euro area: a global VAR analysis. Journal of applied econometrics, 22(1), 1-38.

Dell'Ariccia, G., Detragiache, E., \& Rajan, R. (2008). The real effect of banking crises. Journal of Financial Intermediation, 17(1), 89-112.

Engle, R. F., \& Manganelli, S. (2004). CAViaR: Conditional autoregressive Value-at-Risk by regression quantiles. Journal of Business \& Economic Statistics, 22(4), 367-381.

Fong, T. P. W., \& Wong, A. Y. (2012). Gauging potential sovereign risk contagion in Europe. Economics Letters, 115(3), 496-499.

Girardi, G., \& Ergün, A. T. (2013). Systemic risk measurement: Multivariate GARCH estimation of CoVaR. Journal of Banking \& Finance, 37(8), 3169-3180.

Grammatikos, T., \& Vermeulen, R. (2014). The 2007-2009 financial crisis: changing market dynamics and the impact of credit supply and aggregate demand sensitivity. Applied Economics, 46(8), 895-911.

Hartmann, P., Straetmans, S., \& Vries, C. D. (2004). Asset market linkages in crisis periods. Review of Economics and Statistics, 86(1), 313-326.

Jarrow, R. A. (2011). The Role of ABS, CDS and CDOs in the Credit Crisis and the Economy. Rethinking the Financial Crisis, 210-234.

Jinjarak, Y., \& Zheng, H. (2014). Granular institutional investors and global market interdependence. Journal of International Money and Finance, 46, 61-81.

Koenker, R., \& Bassett Jr, G. (1978). Regression quantiles. Econometrica: Journal of the Econometric Society, 33-50.

Kroszner, R. S., Laeven, L., \& Klingebiel, D. (2007). Banking crises, financial dependence, and growth. Journal of Financial Economics, 84(1), 187-228.

Laeven, L., \& Valencia, F. (2013). The real effects of financial sector interventions during crises. Journal of money, credit and Banking, 45(1), 147-177.

Levine, R. (1997). Financial Development and Economic Growth: Views and Agenda. Journal of Economic Literature, 35(2), 688-726. 
López-Espinosa, G., Moreno, A., Rubia, A., \& Valderrama, L. (2012). Short-term wholesale funding and systemic risk: A global CoVaR approach. Journal of Banking \& Finance, 36(12), 3150-3162.

Neave, E. H. (2009). Modern financial systems: theory and applications (Vol. 183). John Wiley \& Sons.

Park, Y. C., \& Song, C. Y. (2001). Financial contagion in the East Asian crisis: With special reference to the Republic of Korea. In International financial contagion (pp. 241-265). Springer, Boston, MA.

Pesaran, M. H., \& Shin, Y. (1998). An autoregressive distributed-lag modelling approach to cointegration analysis. Econometric Society Monographs, 31, 371-413.

Raddatz, C. (2006). Liquidity needs and vulnerability to financial underdevelopment. Journal of financial economics, 80(3), 677-722.

Rajan, R. G., \& Zingales, L. (1998). Financial Dependence and Growth. The American Economic Review, 88(3), $559-586$.

Schumpeter, J. A. (1911), A Theory of Economic Development, Harvard University Press.

Sims, C. A. (1980). Macroeconomics and reality. Econometrica: Journal of the Econometric Society, 1-48.

Sharifova, M. (2012). Measuring Cross-Border Linkages between US and European Banking Institutions. SIGFIRM Working paper No.19

Tong, H., \& Wei, S. J. (2008). Real effects of the subprime mortgage crisis: is it a demand or a finance shock? (No. w14205). National Bureau of Economic Research.

Tsay, R. S. (2010). Analysis of Financial Time Series. John Wiley \& Sons.

Wong, A. Y., \& Fong, T. P. W. (2011). Analysing interconnectivity among economies. Emerging Markets Review, 12(4), 432-442. 


\section{Chapter 5: Summary and Conclusions}

The desire to improve understanding of the antecedents and consequences of riskiness from the banking sector and its economic significance serve as the primary motivation of this study. The primary goal of this thesis has been to investigate several issues relating to riskiness in banks. The first two essays examine riskiness arising within the financial sector. The focus is on how banks' opportunistic accounting practices affect banks' risk profiles and how bank investors respond when banks present as using opportunistic accounting practices. The third essay examines how tail risks from the financial sector are related to tail risks in real sub-sectors. Altogether, this thesis contributes empirical evidence to the banking risk management literature.

The first essay (Chapter 2) find that banks' discretionary accounting practices, which are captured by bank managers' discretionary loan loss provisioning practices, accumulated for 4 quarters, lead to greater information uncertainty among banks' equity investors, and results in low $S T I$ and high $S P C R$. These findings suggest that banks' $D L L P$ practices increase banks' financial information opacity.

The second essay (Chapter 3) finds that banks' depositors treat banks' discretionary loan loss provisioning practices as a credit risk-increasing factor. The depositors punish banks' bad behavior by reducing funds supplied or requiring higher interest rates. However, depositors' risk sensitivity is affected by their perceptions of explicit or implicit government guarantees for banks. We find that for TBTF banks depositors react sensitively to $D L L P$ practices only during the non-crisis period, but not during the crisis period. In addition, banks subject to U.S. government bailout actions during the 2008-2009 crisis period received less depositor discipline than other banks. 
The third essay (Chapter 4) examines tail-risk dependence between the financial sector and real sub-sectors. Traditional Value-at-Risk approaches use an asset's historical return information to estimate future maximum losses. However, assets that are closely related to the financial sector may face even larger losses if the financial sector shifts from a normal state to a distressed state. Using the Conditional Value-at-Risk approach, developed based on Adrian and Brunnermeier (2016), we examine the relationship between changes in the financial sector's Value-at-Risk and real sub-sectors' Value-at-Risk responses. We find that real sub-sectors are closely related to the financial sector in terms of the tail risk of equity prices. We also compare the risk forecasting ability of traditional Value-at-Risk (VaR) measures to Conditional Value-at-Risk (CoVaR) measures. We find that the CoVaR model we propose in this study can be a more conservative tail risk indicator than the traditional VaR model. 


\section{Appendices}

\section{Appendix A for Chapter 2: An alternate provisioning presentation}

\section{A.1 Hypothetical bank balance sheet}

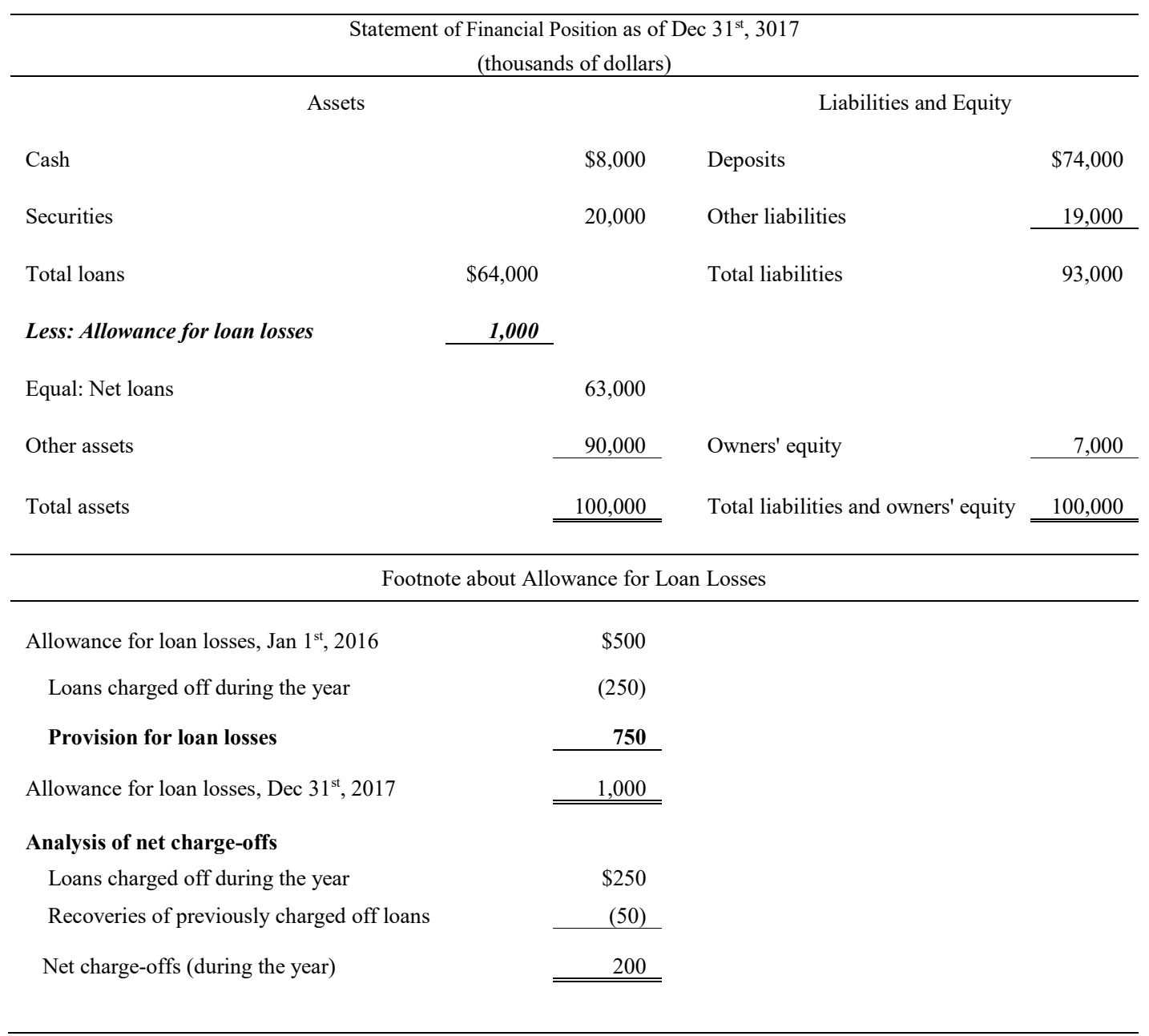




\section{A.2 Hypothetical bank income statement}

\begin{tabular}{|c|c|c|c|}
\hline \multicolumn{4}{|c|}{$\begin{array}{l}2017 \text { Statement of Comprehensive Income } \\
\text { (thousands of dollars) }\end{array}$} \\
\hline Interest income & & $\$ 9,000$ & \\
\hline Noninterest income & & 1,000 & \\
\hline Total income & & & $\$ 10,000$ \\
\hline Interest expense & & 6,000 & \\
\hline \multicolumn{4}{|l|}{ Noninterest expense } \\
\hline Provision for loan losses & $\$ 750$ & & \\
\hline Recoveries of previously charged off loans & $(50)$ & 700 & \\
\hline Other noninterest expense & & 2,700 & \\
\hline Total expense & & & 9,400 \\
\hline Income before taxes & & & 600 \\
\hline Income taxes & & & 150 \\
\hline Net income & & & 450 \\
\hline
\end{tabular}




\section{Appendix B for Chapter 2: Variable definitions and data source}

\begin{tabular}{|c|c|c|}
\hline Variable & Definition & Data source \\
\hline \multicolumn{3}{|c|}{ Variables used to estimate LLP model (1) - (4): } \\
\hline$L L P_{i, t}$ & $\begin{array}{l}\text { Loan loss provision in quarter } t \text { divided by total loans in quarter } t- \\
1 \text {. }\end{array}$ & Compustat \\
\hline$\Delta N P A_{i, t}$ & $\begin{array}{l}\text { The change in non-performing assets between quarter } t \text { and quarter } t \\
-1 \text { divided by total loans in quarter } t-1 \text {. }\end{array}$ & Compustat \\
\hline$S \mathrm{IZE}_{i, t}$ & Natural log of total assets in quarter $t$. & Compustat \\
\hline$\triangle L O A N_{i, t}$ & $\begin{array}{l}\text { The change in total loans between quarter } t \text { and quarter } t-1 \text { divided } \\
\text { by total loans in quarter } t-1 \text {. }\end{array}$ & Compustat \\
\hline$A L W_{i, t}$ & The allowance divided by total loans in quarter $t$. & Compustat \\
\hline$C O_{i, t}$ & The net charge off divided by lagged total loans in quarter $t$. & Compustat \\
\hline$\Delta \mathrm{GDP}_{t}$ & The change in GDP between quarter $t$ and quarter $t$. & $\begin{array}{l}\text { https://fred.stlo } \\
\text { uisfed.org/ }\end{array}$ \\
\hline $\mathrm{CSRET}_{t}$ & $\begin{array}{l}\text { The return on the Case-Shiller Real Estate Index between quarter } t \\
\text { and quarter } t-1 \text {. }\end{array}$ & $\begin{array}{l}\text { https://fred.stlo } \\
\text { uisfed.org/ }\end{array}$ \\
\hline$\Delta \mathrm{UNEMP}_{t}$ & The change in unemployment rates between quarter $t$ and quarter $t-1$ & $\begin{array}{l}\text { https://fred.stlo } \\
\text { uisfed.org/ }\end{array}$ \\
\hline
\end{tabular}

The DLLP measures to be used in equation (8):

$D L L P 1_{i, t} \quad$ One period $D L L P$ for bank $i$ at quarter $t$, which is calculated as the absolute value of residuals from LLP model (1).

$D L L P 2_{i, t} \quad$ One period $D L L P$ for bank $i$ at quarter $t$, which is calculated as the absolute value of residuals from LLP model (2).

$D L L P 3_{i, t} \quad$ One period DLLP for bank $i$ at quarter $t$, which is calculated as the absolute value of residuals from LLP model (3).

$D L L P 4_{i, t} \quad$ One period DLLP for bank $i$ at quarter $t$, which is calculated as the absolute value of residuals from LLP model (4).

The $A D L L P$ measures to be used in equation (9):

$A D L L P 1_{i, t} \quad$ The accumulated $D L L P 1$ for bank $i$ at quarter $t$, which is calculated as: $A D L L P 1_{i, t}=D L L P 1_{i, t}+D L L P 1_{i, t-1}+D L L P 1_{i, t-2}+$ $D L L P 1_{i, t-3}$.

$A D L L P 2_{i, t} \quad$ The accumulated $D L L P 2$ for bank $i$ at quarter $t$, which is calculated as: $A D L L P 2_{i, t}=D L L P 2_{i, t}+D L L P 2_{i, t-1}+D L L P 2_{i, t-2}+$ $D L L P 2_{i, t-3}$.

$A D L L P 3_{i, t} \quad$ The accumulated $D L L P 3$ for bank $i$ at quarter $t$, which is calculated as: $A D L L P 3_{i, t}=D L L P 3_{i, t}+D L L P 3_{i, t-1}+D L L P 3_{i, t-2}+$ $D L L P 3_{i, t-3}$.

$A D L L P 4_{i, t} \quad$ The accumulated DLLP4 for bank $i$ at quarter $t$, which is calculated as: $A D L L P 4_{i, t}=D L L P 4_{i, t}+D L L P 4_{i, t-1}+D L L P 4_{i, t-2}+$ $D L L P 4_{i, t-3}$. 


\begin{tabular}{|c|c|c|}
\hline Variable & Definition & Data source \\
\hline \multicolumn{3}{|c|}{ The $S T I$ measures to be used in equation (8) and (9): } \\
\hline BidAsk $_{i, t}$ & $\begin{array}{l}\text { The average bid-ask spread measure for bank } i \text { in quarter } t \text {, which is } \\
\text { calculated using equation (6). }\end{array}$ & CRSP \\
\hline Amihud $_{i, t}$ & $\begin{array}{l}\text { The average Amihud illiquidity for bank } i \text { in quarter } t \text {, which is } \\
\text { calculated using equation (7). }\end{array}$ & CRSP \\
\hline$Z E R O_{i, t}$ & $\begin{array}{l}\text { The ratio of bank } i \text { 's zero-return trading days over the bank's total } \\
\text { trading days in the quarter } t \text {. }\end{array}$ & CRSP \\
\hline \multicolumn{3}{|c|}{ Control variables used in equation (8) and (9): } \\
\hline$R O A_{i, t}$ & Net income divided by total assets for bank $i$ in quarter $t$. & Compustat \\
\hline$S I Z E_{i, t}$ & Natural log of total assets for bank $i$ in quarter $t$. & Compustat \\
\hline TIER $1_{i, t}$ & The Tier-1 risk-adjusted capital ratio for bank $i$ in quarter $t$. & Compustat \\
\hline$\Delta \operatorname{Loan}_{i, t}$ & $\begin{array}{l}\text { The change in total loans between quarter } t \text { and quarter } t-1 \text { divided } \\
\text { by total loans for bank } i \text { in quarter } t-1 \text {. }\end{array}$ & Compustat \\
\hline Depo $_{i, t}$ & The total deposits divided by total loans for bank $i$ in quarter $t$. & Compustat \\
\hline$M T B_{i, t}$ & $\begin{array}{l}\text { The ratio of market value of equity over the book value of equity for } \\
\text { bank } i \text { in quarter } t \text {, where market value is calculated as the common } \\
\text { shares outstanding times the price at the end of the quarter. }\end{array}$ & $\begin{array}{l}\text { Compustat, } \\
\text { CRSP }\end{array}$ \\
\hline Turnover $_{i, t}$ & $\begin{array}{l}\text { The natural logarithm of the average of the share volume divided by } \\
\text { shares outstanding for bank } i \text { in quarter } t \text {. }\end{array}$ & CRSP \\
\hline$R E T_{i, t}$ & $\begin{array}{l}\text { The quarterly average of the daily returns for bank } i \text { over the quarter } \\
t \text {. }\end{array}$ & CRSP \\
\hline$R E T_{-} V_{o l} l_{i, t}$ & The standard deviation of daily returns for bank $i$ over the quarter $t$. & CRSP \\
\hline Price $_{i, t}$ & The average stock price of the stock for bank $i$ over the quarter $t$. & CRSP \\
\hline$V I X_{t}$ & The average value of CBOE Volatility Index over the quarter $t$. & $\mathrm{CBOE}$ \\
\hline$S_{P R E T_{t}}$ & The average return on S\&P Composite Index over the quarter $t$. & CRSP \\
\hline$B I G 4_{i, t}$ & $\begin{array}{l}\text { A dummy variable set to one if bank } i \text { audited by 'Big4' auditing } \\
\text { firms and zero otherwise. }\end{array}$ & Compustat \\
\hline$N A S D A Q_{i, t}$ & $\begin{array}{l}\text { A dummy variable set to one if bank } i \text { is listed in NASDAQ and zero } \\
\text { otherwise. }\end{array}$ & CRSP \\
\hline \multicolumn{3}{|c|}{ The $D L L P$ measures to be used in equation (12): } \\
\hline$D L L P 1_{i, t}^{\prime}$ & $\begin{array}{l}\text { The sum of the } 4 \text { quarters' } D L L P 1 \text { in year } \mathrm{t} \text {, which is calculated } \\
\text { using equation (13). }\end{array}$ & - \\
\hline$D L L P 2^{\prime}{ }_{i, t}$ & $\begin{array}{l}\text { The sum of the } 4 \text { quarters' } D L L P 2 \text { in year } t \text {, which is calculated } \\
\text { using equation (13). }\end{array}$ & - \\
\hline$D_{L L P 3^{\prime}}{ }_{i, t}$ & $\begin{array}{l}\text { The sum of the } 4 \text { quarters' } D L L P 3 \text { in year } t \text {, which is calculated } \\
\text { using equation (13). }\end{array}$ & - \\
\hline$D L L P 4^{\prime}{ }_{i, t}$ & $\begin{array}{l}\text { The sum of the } 4 \text { quarters' DLLP4 in year } t \text {, which is calculated } \\
\text { using equation (13). }\end{array}$ & - \\
\hline
\end{tabular}




\begin{tabular}{|c|c|c|}
\hline Variable & Definition & Data source \\
\hline \multicolumn{3}{|c|}{ The $S P C R$ measures used in equation (12): } \\
\hline$N S K E W_{i, t}$ & $\begin{array}{l}\text { The negative skewness for for bank } i \text { in quarter } t \text {, which is calculated } \\
\text { using equation (10). }\end{array}$ & CRSP \\
\hline \multicolumn{3}{|c|}{ Control variables used in equation (12): } \\
\hline$R O A_{i, t}$ & Net income divided by total assets for bank $i$ in year $t$. & Compustat \\
\hline$S I Z E_{i, t}$ & Natural log of total assets for bank $i$ in year $t$. & Compustat \\
\hline $\operatorname{TIER} 1_{i, t}$ & The Tier-1 risk-adjusted capital ratio for bank $i$ in year $t$. & Compustat \\
\hline$\Delta \operatorname{Loan}_{i, t}$ & $\begin{array}{l}\text { The change in total loans between year } t \text { and year } t-1 \text { divided by } \\
\text { total loans for bank } i \text { in year } t-1 \text {. }\end{array}$ & Compustat \\
\hline $\operatorname{Depo}_{i, t}$ & The total deposits divided by total loans for bank $i$ in year $t$. & Compustat \\
\hline$M T B_{i, t}$ & $\begin{array}{l}\text { The ratio of market value of equity over the book value of equity for } \\
\text { bank } i \text { in year } t \text {, where market value is calculated as the common } \\
\text { shares outstanding times the price at the end of the year. }\end{array}$ & $\begin{array}{l}\text { Compustat, } \\
\text { CRSP }\end{array}$ \\
\hline Turnover $_{i, t}$ & $\begin{array}{l}\text { The natural logarithm of the average of the share volume divided by } \\
\text { shares outstanding for bank } i \text { in year } t \text {. }\end{array}$ & CRSP \\
\hline$R E T_{i, t}$ & The quarterly average of the daily returns for bank $i$ over the year $t$. & CRSP \\
\hline$R E T_{-} V_{o l} l_{i, t}$ & The standard deviation of daily returns for bank $i$ over the year $t$. & CRSP \\
\hline Price $_{i, t}$ & The average stock price of the stock for bank $i$ over the year $t$. & CRSP \\
\hline BidAsk $_{i, t}$ & $\begin{array}{l}\text { The average bid-ask spread measure for bank } i \text { in year } t \text {, which is } \\
\text { calculated using equation (6). }\end{array}$ & CRSP \\
\hline$V I X_{t}$ & The average value of CBOE Volatility Index over the year $t$. & CBOE \\
\hline$S P R E T_{t}$ & The average return on S\&P Composite Index over the year $t$. & CRSP \\
\hline$B I G 4_{i, t}$ & $\begin{array}{l}\text { A dummy variable set to one if bank } i \text { audited by 'Big } 4 \text { ' auditing } \\
\text { firms and zero otherwise. }\end{array}$ & Compustat \\
\hline$N A S D A Q_{i, t}$ & $\begin{array}{l}\text { A dummy variable set to one if bank } i \text { is listed in NASDAQ and zero } \\
\text { otherwise. }\end{array}$ & CRSP \\
\hline
\end{tabular}




\section{Appendix C for Chapter 3: Variable definitions and data source}

\begin{tabular}{|c|c|c|}
\hline Variable & Definition & Data source \\
\hline \multicolumn{3}{|c|}{ Variables used to estimate LLP model (1) - (4): } \\
\hline$L L P_{i, t}$ & $\begin{array}{l}\text { Loan loss provision in quarter } t \text { divided by } \\
\text { total loans in quarter } t-1\end{array}$ & Call report \\
\hline$\triangle N P A_{i, t}$ & $\begin{array}{l}\text { The change in non-performing assets } \\
\text { between quarter } t \text { and quarter } t-1 \text { divided } \\
\text { by total loans in quarter } t-1 \text {. }\end{array}$ & Call report \\
\hline$S \mathrm{IZE}_{i, t-1}$ & Natural log of total assets in quarter $t-1$ & Call report \\
\hline$\triangle L O A N_{i, t}$ & $\begin{array}{l}\text { The change in total loans between quarter } t \\
\text { and quarter } t-1 \text { divided by total loans in } \\
\text { quarter } t-1\end{array}$ & Call report \\
\hline$A L W_{i, t-1}$ & $\begin{array}{l}\text { The allowance divided by total loans in } \\
\text { quarter } t-1\end{array}$ & Call report \\
\hline$C O_{i, t}$ & $\begin{array}{l}\text { The net charge off divided by lagged total } \\
\text { loans in quarter } t\end{array}$ & Call report \\
\hline$\Delta \mathrm{GDP}_{t}$ & $\begin{array}{l}\text { The change in GDP between quarter } t \text { and } \\
\text { quarter } t-1\end{array}$ & $\begin{array}{l}\text { https://fred.stl } \\
\text { ouisfed.org/ }\end{array}$ \\
\hline $\operatorname{CSRET}_{t}$ & $\begin{array}{l}\text { The return on the Case-Shiller Real Estate } \\
\text { Index between quarter } t \text { and quarter } t-1\end{array}$ & $\begin{array}{l}\text { https://fred.stl } \\
\text { ouisfed.org/ }\end{array}$ \\
\hline$\triangle \mathrm{UNEMP}$ & $\begin{array}{l}\text { The change in unemployment rates between } \\
\text { quarter } t \text { and quarter } t-1\end{array}$ & $\begin{array}{l}\text { https://fred.stl } \\
\text { ouisfed.org/ }\end{array}$ \\
\hline \multicolumn{3}{|l|}{ Variables used to estimate equation (5): } \\
\hline DLLP1 & $\begin{array}{l}\text { The absolute value of residuals from LLP } \\
\text { model (1) }\end{array}$ & - \\
\hline DLLP2 & $\begin{array}{l}\text { The absolute value of residuals from LLP } \\
\text { model (2) }\end{array}$ & - \\
\hline DLLP3 & $\begin{array}{l}\text { The absolute value of residuals from LLP } \\
\text { model (3) }\end{array}$ & - \\
\hline DLLP4 & $\begin{array}{l}\text { The absolute value of residuals from LLP } \\
\text { model (4) }\end{array}$ & - \\
\hline Uninsured_Deposit_Growth_Rate ${ }_{i, t}$ & $\begin{array}{l}\frac{\text { Uninsured Deposit }{ }_{t} \text {-Uninsured Deposit }}{t-1} \text {, whinsured Deposit } t-1 \\
\text { Uninsured Deposit is computed using } \\
\text { following the steps in Berger and Turk-Ariss } \\
(2015) \text { (see footnote } 7) .\end{array}$ & Call report \\
\hline Insured_Deposit_Growth_Rate $e_{i, t}$ & $\begin{array}{l}\frac{\text { Insured Deposit }}{t-\text { Insured Deposit }_{t-1}} \text {, where } \\
\text { Insured Deposit } t-1 \\
\text { Insured Deposit is computed as Total } \\
\text { deposit-Uninsured Deposit. }\end{array}$ & Call report \\
\hline Interest expenses $\%_{i, t}$ & $\begin{array}{l}\text { The ratio of total interest expense on } \\
\text { deposits to total deposits in quarter } t \text {. }\end{array}$ & Call report \\
\hline $\operatorname{TIER} 1_{i, t-1}$ & $\begin{array}{l}\text { The Tier- } 1 \text { risk-adjusted capital ratio in } \\
\text { quarter } t-1 \text {. }\end{array}$ & Call report \\
\hline
\end{tabular}




\begin{tabular}{|c|c|c|}
\hline Variable & Definition & Data source \\
\hline$N P A_{i, t-1}$ & $\begin{array}{l}\text { Non-performing assets in quarter } t-1 \text { scaled } \\
\text { by total loans in quarter } t-1 \text {. }\end{array}$ & Call report \\
\hline RealEstate $\%_{i, t-1}$ & $\begin{array}{l}\text { Real estate loans scaled by total loans in } \\
\text { quarter } t-1 \text {. }\end{array}$ & Call report \\
\hline Non_Interest_Income $e_{i, t-1}$ & $\begin{array}{l}\text { The ratio of non-interest income to total } \\
\text { income in quarter } t-1 \text {. }\end{array}$ & Call report \\
\hline Non_Deposit_Funding $g_{i, t-1}$ & $\begin{array}{l}\text { The ratio of non-deposit funding to total } \\
\text { assets in quarter } t-1 \text {. }\end{array}$ & Call report \\
\hline Liquidity_Ratio $_{i, t-1}$ & $\begin{array}{l}\text { The ratio of cash and balances due from } \\
\text { depository institutions plus the held-to- } \\
\text { maturity U.S. Treasury securities to total } \\
\text { assets in quarter } t-1 \text {. }\end{array}$ & Call report \\
\hline$S I Z E_{i, t-1}$ & Natural $\log$ of total assets in quarter $t-1$ & Call report \\
\hline$R O A_{i, t-1}$ & $\begin{array}{l}\text { Net income divided by total assets in quarter } \\
t-1 \text {. }\end{array}$ & Call report \\
\hline Total Deposits $_{i, t-1}$ & Natural log of total deposits in quarter $t-1$. & Call report \\
\hline Tbill_3 $3 M_{t-1}$ & $\begin{array}{l}\text { Three-month Treasury bill rate in quarter } t- \\
1 .\end{array}$ & $\begin{array}{l}\text { https://fred.stl } \\
\text { ouisfed.org/ }\end{array}$ \\
\hline$T 10 Y 3 M_{t-1}$ & $\begin{array}{l}\text { The term spread in quarter } t-1 \text {, measured as } \\
\text { difference between } 10 \text {-year bond yield and } \\
\text { the } 3 \text {-month Treasury bill rate }\end{array}$ & $\begin{array}{l}\text { https://fred.stl } \\
\text { ouisfed.org/ }\end{array}$ \\
\hline Ted_Rate $_{t-1}$ & $\begin{array}{l}\text { The market funding liquidity measure in } \\
\text { quarter } t-1 \text {, defined as the difference } \\
\text { between the 3-month LIBOR rate and the } 3 \text { - } \\
\text { month Treasury bill rate }\end{array}$ & $\begin{array}{l}\text { https://fred.stl } \\
\text { ouisfed.org/ }\end{array}$ \\
\hline
\end{tabular}




\section{Appendix D for Chapter 4: Definitions of sectors}

\begin{tabular}{ll}
\hline Name & Definitions \\
\hline Food & Food \\
Mines & Mining and Minerals \\
Oil & Oil and Petroleum Products \\
Clths & Textiles, Apparel \& Footwear \\
Durbl & Consumer Durables \\
Chems & Chemicals \\
Cnsum & Drugs, Soap, Perfumes, Tobacco \\
Cnstr & Construction and Construction Materials \\
Steel & Steel Works etc \\
FabPr & Fabricated Products \\
Machn & Machinery and Business Equipment \\
Cars & Automobiles \\
Trans & Transportation \\
Utils & Utilities \\
Rtail & Retail Stores \\
Finan & Banks, Insurance Companies, and Other Financials \\
Other & Other \\
\hline
\end{tabular}

Notes: Source: Fama and French Data Library: 17 Industry Portfolios

http://mba.tuck.dartmouth.edu/pages/faculty/ken.french/Data_Library/det_17_ind_port.html 


\section{Appendix E for Chapter 4: Forecasts of $\mathrm{VaR}, \mathrm{CoVaR}$ and $\triangle \mathrm{CoVaR}$ for 16 real sub-}

sectors
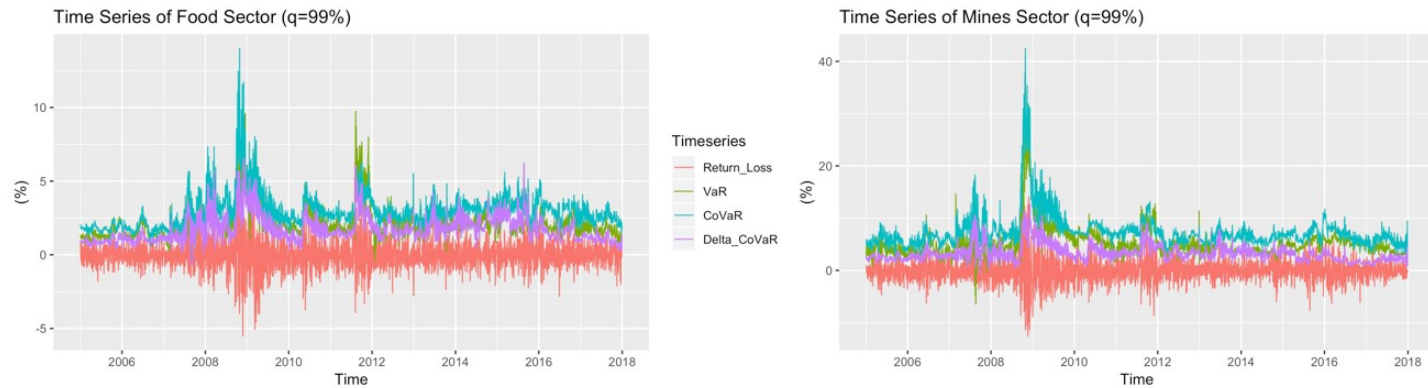

Timeseries

- Return_Loss

- Var

CoVar
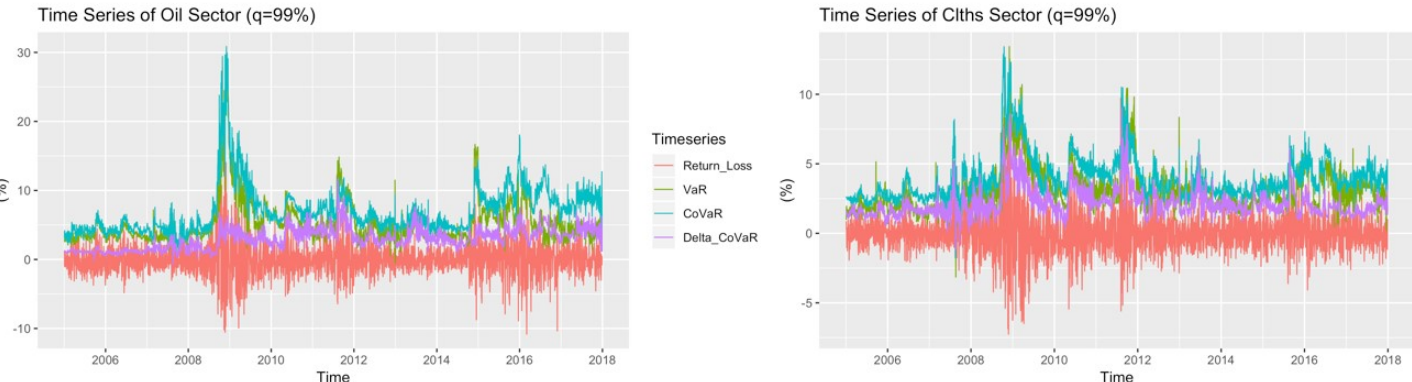

Timeseries

- Return_Loss

- Var

Time Series of Durbl Sector ( $q=99 \%)$
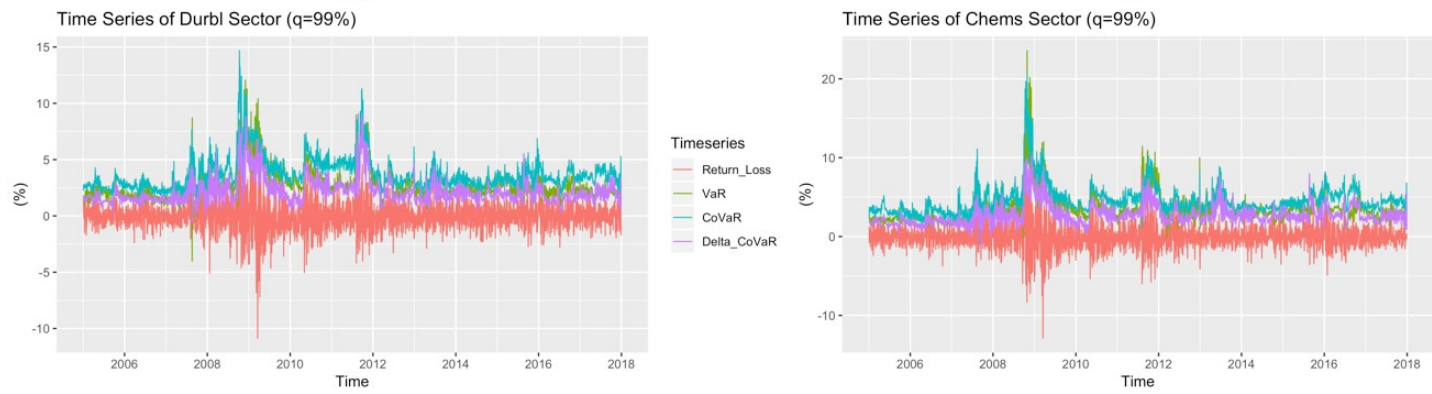

Timeseries
- Return_Loss

- Return_Loss

- VaR
- Covar

- Della_Covar

Time Series of Cnsum Sector ( $q=99 \%$ )
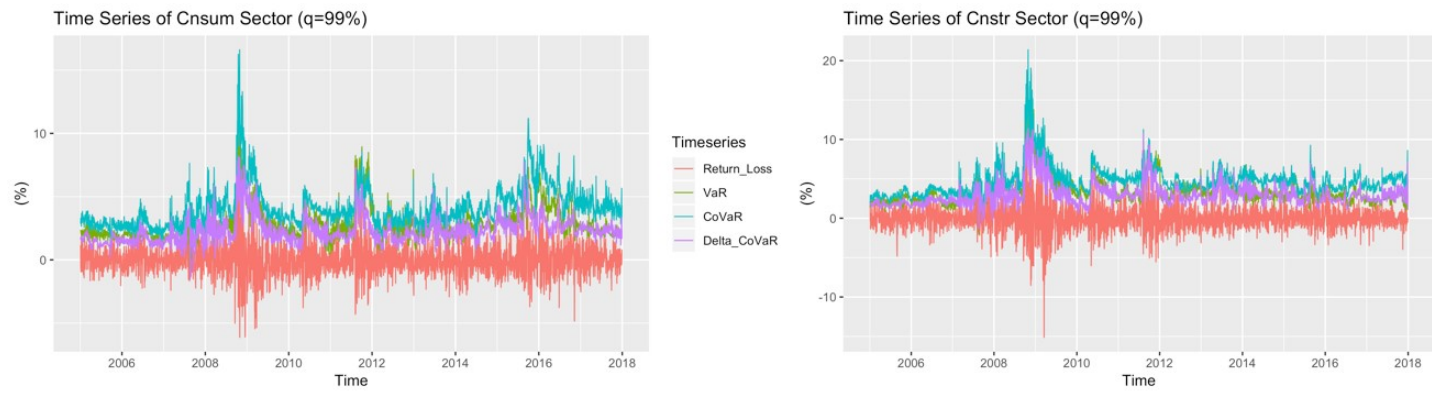

Timeseries

- Return_Los:

- Var

- Delta_Covar 

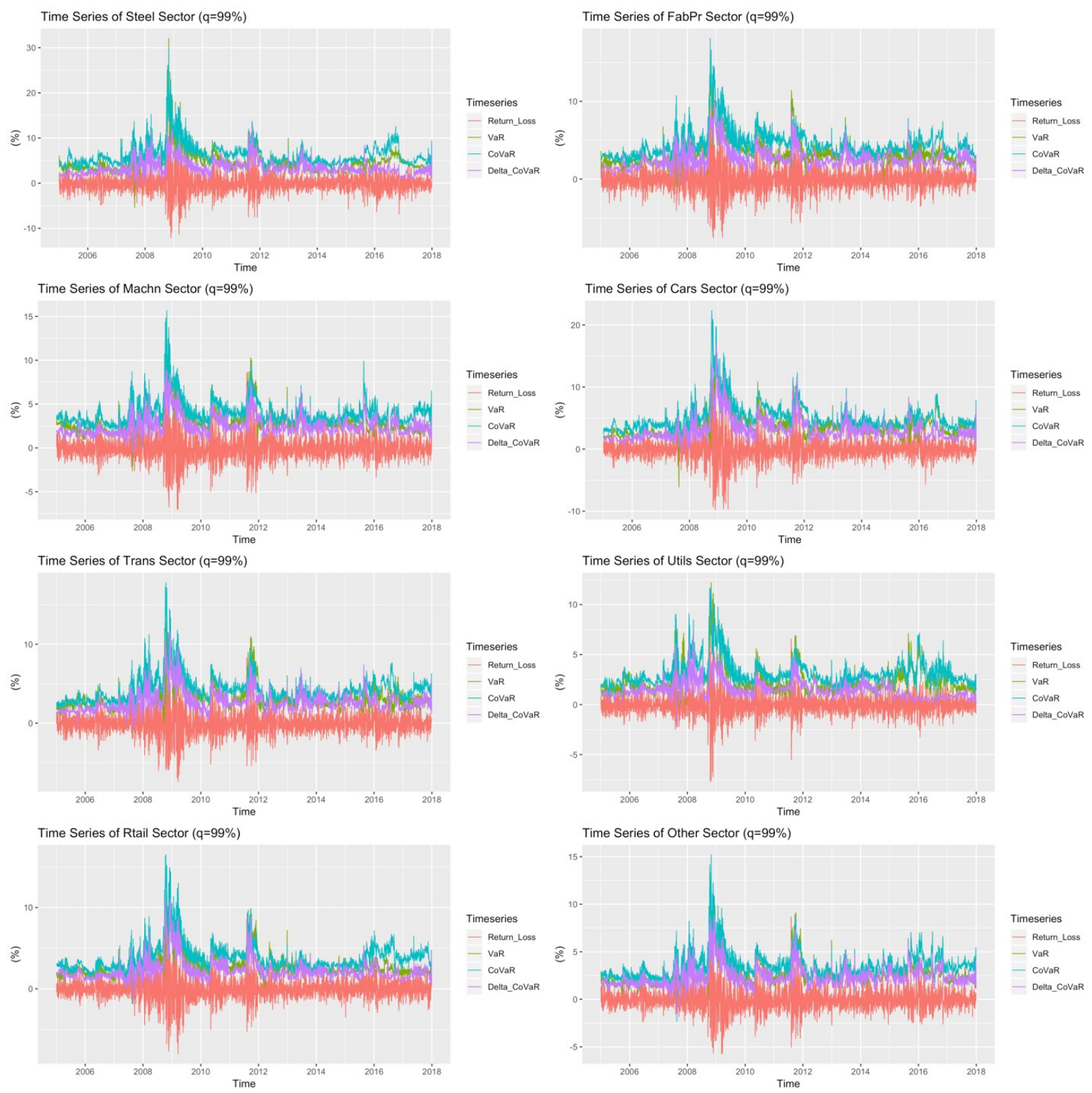

Notes: These figures display plots of the daily estimates of one-day-ahead $\mathrm{VaR}_{99}, \mathrm{CoVaR}_{99 \%}$ and $\Delta \mathrm{CoVaR}_{99 \%}$ and the negative or realized returns for the period 2005-01-04 to 2017-12-29. Adjusted raw returns denoted $r_{t}$ from equation (12) are plotted in red, $\mathrm{VaR}_{99 \%}$ is plotted in blue line, $\mathrm{CoVaR}_{99 \%}$ is plotted in green and $\Delta \mathrm{CoVaR}_{99 \%}$ is plotted in purple, all across time. We make our estimates using data from the 500 trading days preceding each estimate. Sectors are defined based on Compustat SIC and CRSP SIC codes (see Appendix D for sectors' definitions). 
Appendix F for Chapter 4: Time-varying coefficients and error bands for 16 real sub-sectors
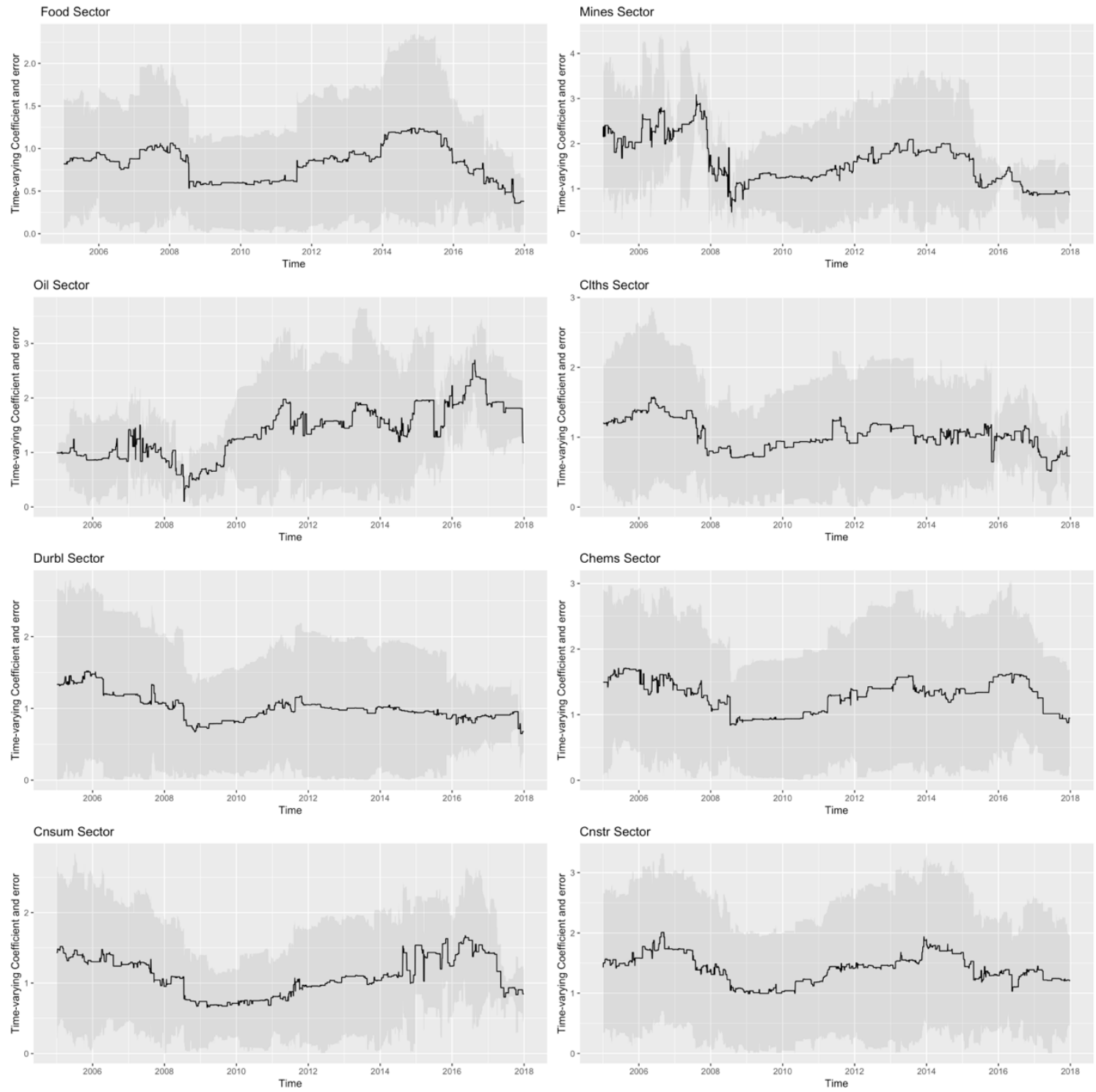

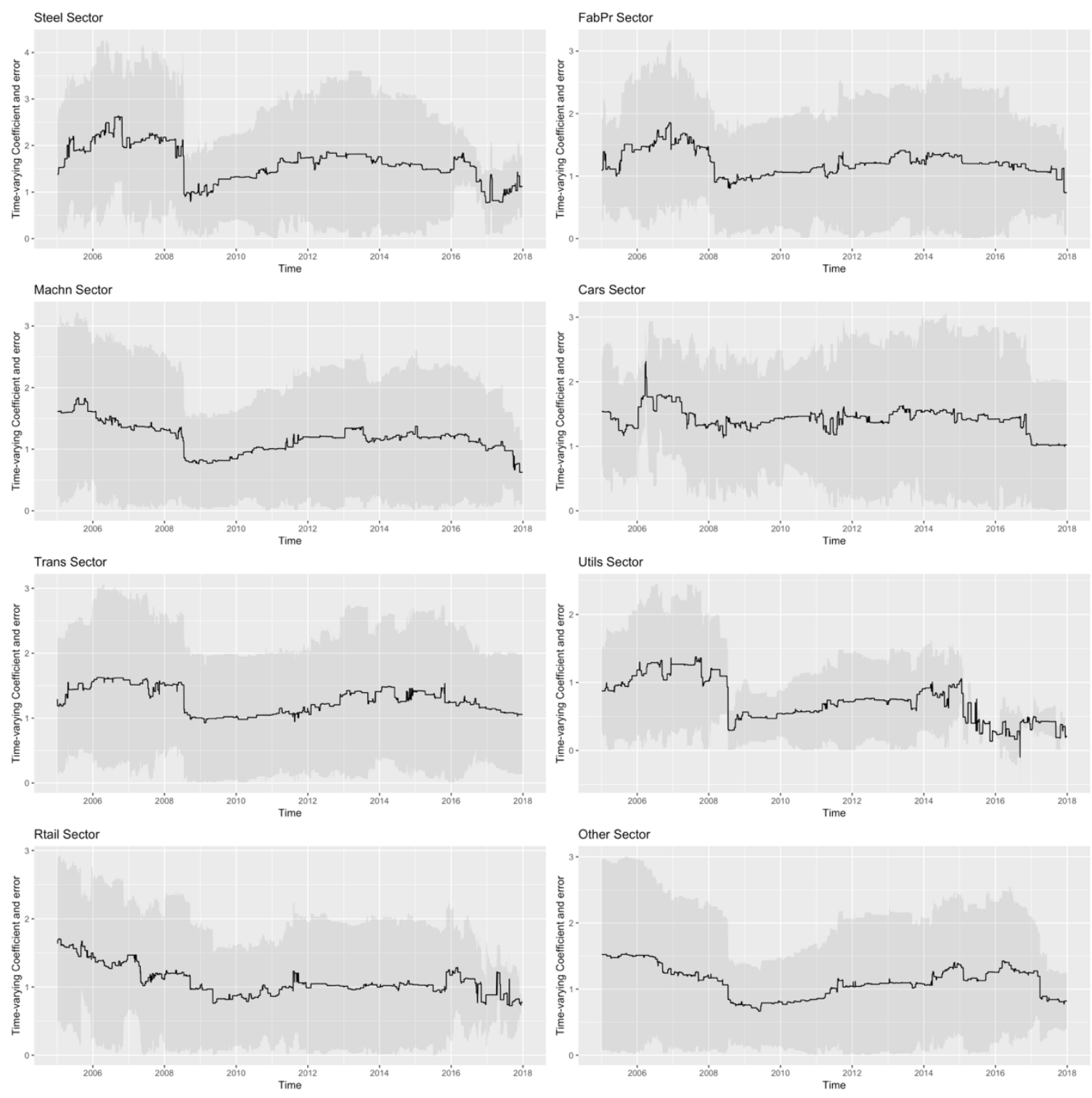

Notes: These figures present plots of the estimated daily coefficient and error band of $\hat{\alpha}_{2, q}$ in equation (10). In equation (10), $\hat{\alpha}_{2, q}$ measures the contribution to each of the real sub-sector risk from the financial sector for the $99 \%$ quantile. For each day commencing 2005-05-18 and ending 2017-12-29, we use data from the 500 trading days preceding each estimate to run equations (8) and (9) to obtain equation (10). We record the coefficient $\hat{\alpha}_{2, q}$ and the standard deviation of $\hat{\alpha}_{2, q}$. Sectors are defined based on Compustat SIC and CRSP SIC codes (see Appendix D for sectors' definitions). 


\section{Appendix G for Chapter 4: IRFs for 16 real sub-sectors}
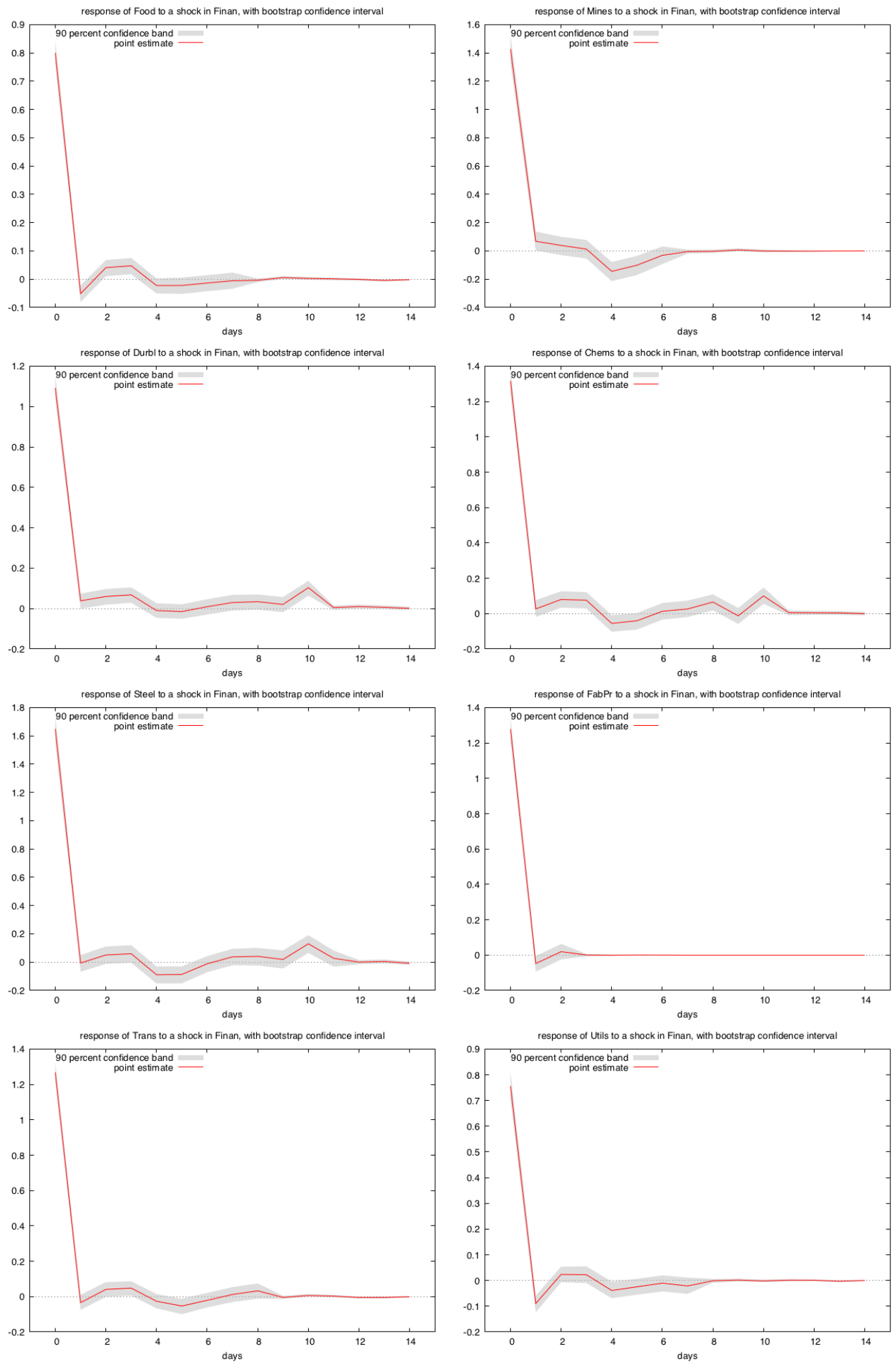

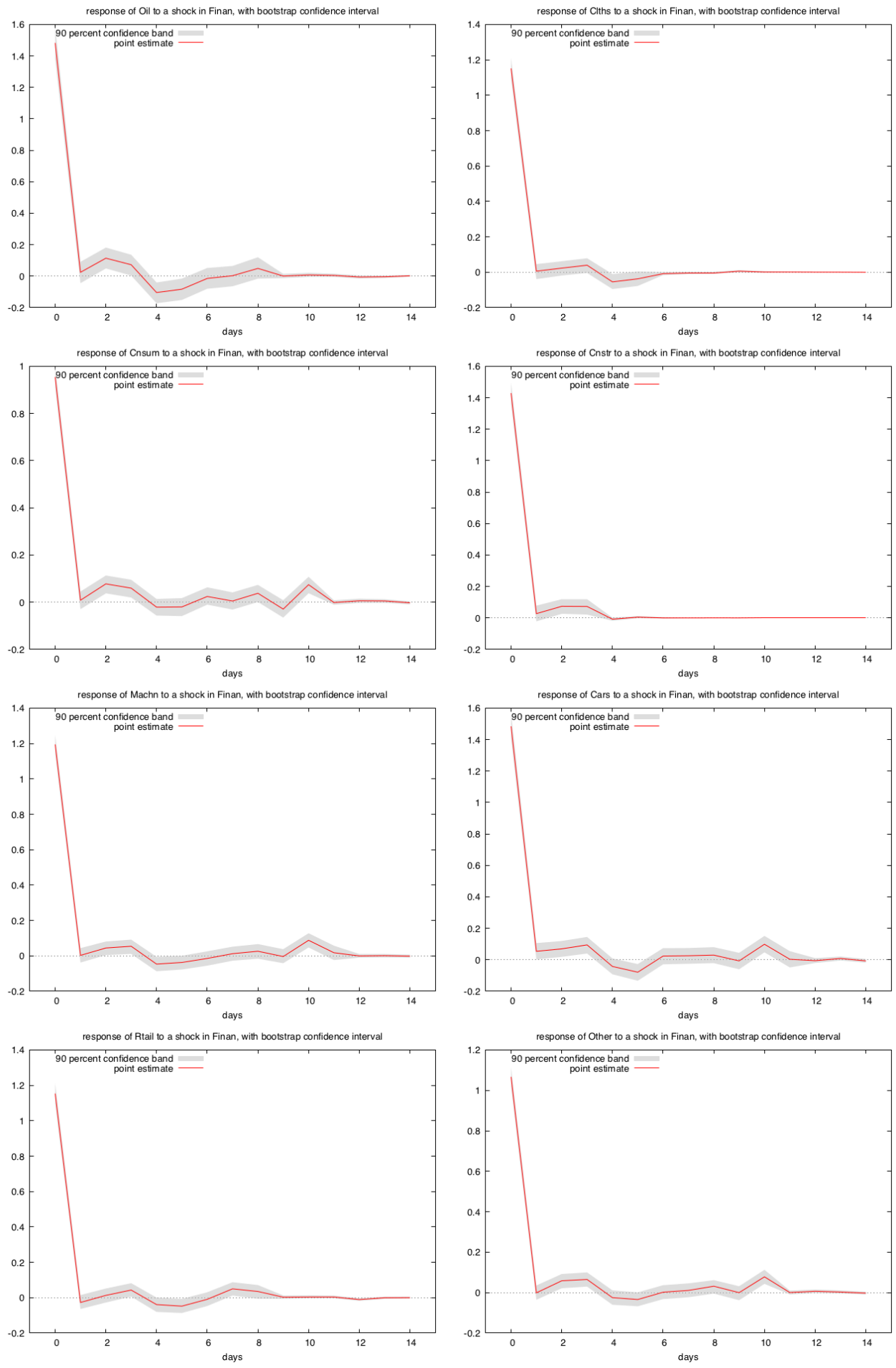

Notes: These figures show how each real sub-sector's stock returns respond to shocks originating from the financial sector's stock returns. The size of the shock of each series is 1 standard deviation. In addition to the size of the response, the IRFs also show how quickly each sector respond, as well as how persistent the response is. The observation period ranges from 2005-01-04 to 2017-12-29. The Vector Autoregression lag selection is based on the Akaike criterion (AIC). The Cholesky ordering is such that the finance sector's return series come first, and shocked sector's return series come last. Sectors are defined based on Compustat SIC and CRSP SIC codes (see Appendix D for sectors' definitions). 